\title{
BEFORE THEY WERE DIAMONDS: \\ THE INTERGENERATIONAL MIGRATION OF KENTUCKY'S COAL CAMP BLACKS
}

\author{
By \\ Karida Leigh Brown \\ BBA, Temple University, 2004 \\ MPA, University of Pennsylvania, 2009 \\ MA, Brown University, 2012
}

Submitted in partial fulfillment of the requirements for the

Degree of Doctor of Philosophy

in the Department of Sociology at Brown University

Providence, Rhode Island May 2016 
C Copyright 2016 by Karida Leigh Brown 
Page intentionally left blank for signature page 
Page intentionally left blank for signature page 


\section{Karida Leigh Brown}

Curriculum Vitae

Mobile 401-500-1662 | E-mail: karida_johnson@brown.edu

Maxcy Hall, Box 1916 |108 George Street |Providence, RI 02155

Born August $9^{\text {th }}, 1982$ in Mineola, New York

\section{Academic Appointments}

June 2016- Assistant Professor of Sociology, University of California Los Angeles

\section{Education}

2016 (expected) PhD, Sociology, Brown University

Dissertation Title: Before they were Diamonds: The Intergenerational Migration of Kentucky's Coal Camp Blacks

Committee: José Itzigsohn (Chair), Michael Kennedy, Paget Henry, Françoise N. Hamlin, Anthony Bogues, William Ferris (UNC Chapel Hill)

2012 M.A., Sociology, Brown University

2009 M.P.A., Government, University of Pennsylvania

2004 B.B.A, Risk Management, Temple University

\section{Research and Teaching Interests}

Cultural Sociology; Race \& Ethnicity; Historical Sociology; Social Theory; Migration; Archival Theory; Oral History; Sociology of Education; African American Studies; Southern Studies

\section{Peer Reviewed Publications}

Itzigsohn, José and Brown, Karida, (2015) "Sociology and the Theory of Double

Consciousness: W. E. B Du Bois' Phenomenology of Racialized Subjectivity" Du Bois Review 12(2).

Brown, Karida, (2016) "Diaspora Starts at Home: Towards a multidimensional conceptualization of home" DIASPORA: A Journal of Transnational Studies, forthcoming.

Brown, Karida, (2016) "The Hidden Injuries of School Desegregation" American Journal of Cultural Sociology, forthcoming.

Brown, Karida, (2016) "On the Participatory Archive: An ethnography of the Eastern Kentucky African American Migration Project" Southern Cultures 22(1). Special issue: Documentary Arts

Brown, Karida, Murphy, Michael, and Porcelli, Apollonya, "Ruin's Progeny: Race, Environment and Appalachia's Coal Camp Blacks" Forthcoming special issue: Race and Environmental Equity). Forthcoming, Spring 2017. 


\section{Works in Progress}

Brown, Karida and Itzigsohn, José, “Re-examining ‘The Field': W.E.B. Du Bois’ Sociological Approach to Community and Urban Studies"

\section{Exhibitions Curated}

"Gone Home: Race and Roots through Appalachia", Melba Remig Saltarelli Exhibit Room, Wilson Special Collections Library, UNC at Chapel Hill. April $28^{\text {th }}$-August 26th ${ }^{\text {st }}, 2015$

\section{Research Projects}

\section{Eastern Kentucky African America Migration Project \\ (2013-Present)}

Founder and Principle Investigator

Facilitating an ongoing participatory archival collection focused on the African American Great Migration. The collection is constructed from the ground up by a cohort of African Americans who share Appalachian roots, and subsequently participated in a mass out-migration from their community during the Great Migration. The collection consists of a combination of oral history interviews, photos and primary materials that will be archived, digitized, and made publicly available through the Southern Historical Collection at the University of North Carolina at Chapel Hill.

http://ekaamp.web.unc.edu/

\section{Fellowships, Grants, Professional Designations}

2015: Ford Foundation Dissertation Writing Fellowship Honorable Mention

2014: Cogut Center for the Humanities Graduate Fellow Full Academic Funding for the 2014-2015 Calendar Year

2014: African American Success Foundation Full Academic Funding for the 2014-2015 Calendar Year

2014: University of North Carolina at Chapel Hill, Southern Historical Collection $\$ 30,000$ dissertation research grant for May 2014-2015 fieldwork

2013: University of North Carolina at Chapel Hill, Southern Historical Collection $\$ 10,000$ research travel grant for Summer 2013 oral history research

2013: Kentucky Historical Society, Technical Assistance Grant Professional audio equipment for the 2013-2015 Calendar Years 
2012: Brown University Population Studies \& Training Center Fellowship Full Academic Funding for the 2012-2013 Academic Year

2012: Brown University Population Studies \& Training Center Seed Research Grant Professional audio equipment for the 2013-2015 Calendar Years

\section{Conference Presentations}

2015: Brown University One-day Colloquia (Conference organizer and presenter) on W.E.B. Du Bois, Max Weber, and the Origins of Sociology: "Sociology and the Theory of Double Consciousness: W. E. B Du Bois' Phenomenology of Racialized Subjectivity”, with Jose Itzigsohn. (October)

2015: University of North Carolina at Chapel Hill, Department of Sociology | Cultural and Political Sociology Workshop: "The Hidden Injuries of School Desegregation: Cultural Trauma and Transforming African American Identities". (October)

2014: New School for Social Science Research Sociology Student Conference, "School Desegregation in an Appalachian Community: Social Dislocation, Cultural Trauma and the Phenomenology of Racialized Subjectivity". (April)

2014: Yale Center for Cultural Sociology $10^{\text {th }}$ Anniversary Conference, "School Desegregation in an Appalachian Community: Social Dislocation, Cultural Trauma and the Phenomenology of Racialized Subjectivity". (April)

2014: Linnaeus University (Växjö, Sweden) Cultural Sociology and Education Conference, "The Hidden Injuries of School Desegregation". (December)

\section{Media}

\section{Radio Broadcasts:}

Interview with Frank Stasio on The State of Things: "Gone Home, The Stories of Black Coal Miners in Appalachia", WUNC: North Carolina Public Radio. Aug. 4 ${ }^{\text {th }}, 2015$

- Rebroadcast on West Virginia Public Broadcasting on Aug. 
Page intentionally left blank for preface and acknowledgements 


\section{TABLE OF CONTENTS}

List of Tables $\quad$ xii

List of Illustrations $\quad$ xiii

Introduction

Introduction $\quad 2$

The African American “Great Migration” (1910-1970) 3

The Case $\quad 8$

Defining the Source Area of Study $\quad 10$

$\begin{array}{ll}\text { Project Aims } & 13\end{array}$

\section{Chapter One}

The Negro Problem in America $\quad 18$

Introduction $\quad 19$

Les Mots et Les Choses: Social Categories and Racialized Subjectivity 21

Towards a Supra-national Interpretation of Race and Racialization 26

What is the Negro: Subject or Citizen? 30

Emergence of the Racial Self: African American Subjectivity 35

Conclusion: A Social Resurrection 38

\section{Chapter Two}

Turning the Screw of Interpretation on the Archive 39

Introduction $\quad 41$

You Got to Get the Story Right $\quad 42$

Methodology 46

Seeing In-Visible $\quad 52$

Archival Technologies $\quad 53$

The New Negro Movement and the Impulse to Archive in Black 58

Returning to EKAAMP $\quad 63$

The Institutional Passage from the Private to the Public 65

$\begin{array}{ll}\text { Conclusion } & 72\end{array}$

SCENE I: THE INTERGENERATIONAL MIGRATION OF KENTUCKY'S

COAL CAMP BLACKS

Chapter Three

$\begin{array}{ll}\text { The Great Migration Escape } & 79\end{array}$

$\begin{array}{ll}\text { Origin Stories } & 79\end{array}$ 
The Sending Area $\quad 84$

The Coming of the Coal Industry 93

The Tri-City Area: Benham, Lynch, and Cumberland, Kentucky 97

Better the Devil You Know...

Getting There, 1915-1940 114

Labor, then Race and Migration $\quad 121$

$\begin{array}{ll}\text { Striving } & 123\end{array}$

$\begin{array}{ll}\text { Conclusion } & 128\end{array}$

\section{Chapter Four}

$\begin{array}{ll}\text { Home } & 132\end{array}$

$\begin{array}{ll}\text { Living Behind the veil } & 132\end{array}$

$\begin{array}{ll}\text { Going Home } & 137\end{array}$

Homescapes $\quad 147$

Growing up in a Coal Town $\quad 152$

The Great Equalizer $\quad 164$

Second Sight and the Emergence of Racial Consciousness 167

$\begin{array}{ll}\text { Conclusion } & 171\end{array}$

SCENE II: FROM NEGRO TO AFRICAN AMERICAN: RACE AND

THE U.S. PUBLIC SCHOOL SYSTEM

\section{Chapter Five}

$\begin{array}{ll}\text { The Colored School } & 175\end{array}$

Introduction $\quad 175$

The Moral Education of the Negro in America 176

The History of Education in Eastern Kentucky $\quad 182$

$\begin{array}{ll}\text { The Black Teacher } & 187\end{array}$

The Interiority of the Colored School 194

Black Pedagogy 199

Encounters with the Veil 202

$\begin{array}{ll}\text { Praxis } & 206\end{array}$

A Change Gone Come 208

\section{Chapter Six}

The Hidden Injuries of School Desegregation $\quad 212$

$\begin{array}{ll}\text { Introduction } & 212\end{array}$

Battleground for Citizenship 213

Negro Discourses on Negro Education $\quad 219$ 
At the Eve of an Era: Anticipating Integration $\quad 223$

A Theory of Cultural Trauma 225

The First Three $\quad 227$

The "Hidden Injuries" of School Desegregation 230

$\begin{array}{ll}\text { The Costs and Benefits of School Desegregation } & 239\end{array}$

From "Hidden Injuries" to Cultural Trauma 242

$\begin{array}{ll}\text { Discussion } & 249\end{array}$

$\begin{array}{ll}\text { Conclusion } & 251\end{array}$

\section{Chapter Seven}

Gone Home: Race and Roots through Appalachia 253

$\begin{array}{ll}\text { Introduction } & 253\end{array}$

Move it on Down the Line... 259

Gone Home $\quad 269$

Race and Roots through Appalachia $\quad 282$

Conclusion 285

$\begin{array}{ll}\text { Conclusion } & 286\end{array}$

A Reflexive Note $\quad 286$

Striving, Transformation, and the Improvisation of Blackness 288

Coda: What's the Counterfactual? 292

$\begin{array}{lr}\text { Bibliography } & 294\end{array}$

\section{Appendices}

Appendix A: Interviewee Schedule 309

Appendix B: IRB Consent and Deed of Gift Forms 313 


\section{LIST OF TABLES}

Table 1: Descriptive Statistics of Interview Sample 


\section{LIST OF ILLUSTRATIONS}

Figure 1: Map of U.S. Appalachian Counties

Figure 2: Map of Appalachian Counties in Kentucky

Figure 3: Photograph of EKAAMP Interview \#114

Figure 4: Photograph of Pearl, the Rev. Edgar James Moss Collection

Figure 5: Photograph of EKAAMP Site Visit \#2, Rev. Moss

Figure 6: Photograph of EKAAMP Site Visit \#3, Rev. Moss

Figure 7: Photograph of Rev. Moss Collection Deed of Gift

Figure 8: Photograph of Rev. Moss Collection Delivery

Figure 9: Photograph of the Lynching of Lige Daniels

Figure 10: Map of Appalachian Counties in Kentucky

Figure 11: Photograph of Lynch, Kentucky Officials

Figure 12: Map of Study Source Area

Figure 13: Photograph of Temporary Shanty in Lynch

Figure 14: Photograph of Sawmill and Hospital Site

Figure 15: Map of Eastern KY Mine Workers, 1930

Figure 16: Photograph of Medical Examiner's Office, Benham

Figure 17: Photograph of Medical Examiner's Office, Lynch

Figure 18: Photograph of Coal Loader in Portal 31, Lynch

Figure 19: Photograph of Black Miners Relaxing on Weekend

Figure 20: Photograph of Miner Farming, Lynch

Figure 21: Photograph of Mothers in Kitchen, Lynch 
Figure 22: Photographs of Miners Changing Shifts, Lynch 148

Figure 23: The Lynch Colored Public School Building (LCPS), c.1940 183

Figure 24: LCPS Teachers at Dance 190

Figure 25: LCPS Teachers with Students 192

Figure 26: LCPS Teachers and Principle 196

Figure 27: LCPS Basketball Team 231

Figure 28: LCPS Building, 2014

Figure 29: LCPS, West Corner, 2014

Figure 30: LCPS, Memorial Bricks, 2014

Figure 31: Map of Eastern Kentucky Social Club Diaspora 268

Figure 32: Photograph of Lynch High School, 2015

Figure 33: Photograph of Demolished 4 ${ }^{\text {th }}$ Street, Lynch 274

Figure 34: Photograph of Demolished Community, Benham 275 


\section{INTRODUCTION}

"From the deep and the near South the sons and daughters of newly freed African slaves wander into the city. Isolated, cut off from memory, having forgotten the name of the gods and only guessing at their faces, they arrive dazed and stunned, their heart kicking in their chest with a song worth singing. They arrive carrying Bibles and guitars, their pockets lined with dust and fresh hope, marked men and women seeking to scrape from the narrow, crooked cobbles and the fiery blasts of the coke furnace a way of bludgeoning and shaping the malleable parts of themselves into a new identity as free men of definite and sincere worth."

--August Wilson (1990) Joe Turner's Come and Gone

"The actions of the people in this book were both universal and distinctly American. Their migration was a response to an economic and social structure not of their making. They did what humans have done for centuries when life became untenable--what the pilgrims did under the tyranny of British rule, what the ScotchIrish did in Oklahoma when the land turned to dust, what the Irish did when there was nothing to eat, what the European Jew did during the spread of Nazism, what the landless in Russia, Italy, China, and elsewhere did when something better across

the ocean called to them. What binds these stories together was the back-againstthe-wall, reluctant yet hopeful search for something better, any place but where they were. They did what human beings looking for freedom, throughout history, have

done.

They left." Isabel Wilkerson (2010) The Warmth of Other Suns

"In the very process of being transplanted, the Negro is becoming transformed." Alain Locke (1925) The New Negro 


\section{Introduction}

Mass migration always conditions subjectivities. Whether a result of religious persecution, famine, labor shortage, or the prospect of greater prosperity, every mass movement of a people can be traced through the particular conditions under which the migrant self is formed and transformed. The shared struggles and strivings, and the peeks and valleys of the myriad of hopes, disappointments, tragedies, and joys that accompany the migration experience shape a people. The black experience with migration in the U.S. has been framed by what is commonly referred to as "The African American Great Migration": a period between 1910 and 1970 during which approximately six million blacks migrated from the rural South to the urban centers of the Midwest, the Northeast, and, much later, out West (Grossman, 1991; Harrison, 2012; Lemann, 2011; Marks, 1989; Stewart E. Tolnay, 2003; Wilkerson, 2010). It is true that this period marked an epoch transformation in American history, as it completely redistributed the racial composition of the American city. Yet, we still know very little about what this decadeslong journey meant to the millions of American black folk who experienced it.

In this dissertation, I examine the contours of this awesome demographic event to reveal the vast impact that the social forces of this macro structural transformation had on African American subjectivity. In this work, I take a cultural approach to the study of migration in order to get at the symbolic order, aspirations, and meaning systems that undergirded and sustained the African American Great Migration. The opening epigraphs point to the intangible yet ever-present, what cultural theorist Raymond Williams (2006) called, "structure of feeling" that is my primary object of observation throughout this 
project. Yes, the African American Great Migration entailed the mass movement of a subjugated group of American "citizens" from rural to urban contexts, from a de jure to a de facto racial landscape, from agricultural to industrial laborer economies; but what were the aspirations, desires, and fears that accompanied this black exodus from the U.S. South? What did they hope for, and what did they get? And, looking back, what does it mean to this generation of African American migrants?

Throughout the chapters of this dissertation, I trace the collective process of selfmaking and of striving and becoming along the grain of the African American Great Migration through a retroactive reconstruction of the life histories of one group of migrants: the African Americans who migrated from the plantations of Alabama to the coalfields of eastern Kentucky, and who, after one generation, were subsequently displaced from the land they made home. The second generation - the foci of this research — eventually joined the other five million or more blacks that migrated from the Deep South to the North, Midwest, and Western regions of the country throughout the second wave of The Great Migration (1940-1970). This latter generation left home, usually the day after high school graduation, with little promise of the possibility of return, and resettled in cities all across the nation. They migrated out into an America that was pregnant with new possibilities for blacks; and as our country experienced enormous transformation throughout the pre and post-Civil Rights Era, so too did its black "citizens". It was during this era when the progeny of the formerly enslaved transitioned - from Colored to Negro to Black to African American, from disenfranchised subjects towards that all-too-distant category of Citizen.

\section{The African American “Great Migration” (1910-1970)}


The African American Great Migration is one of the most profound social movements in this country's history: it took place over the course of sixty years with little public protest, no organized blueprint, and without a named leader (Wilkerson, 2010). It fundamentally changed the racial composition of the urban the landscape in America and lead to some of the most divisive riots, protests, and social movements in this country's history (Gregory, 2006; Stewart E. Tolnay, 2003; Wilkerson, 2010).

Sociologists often focus on the economic and social factors that influenced the onset of the African American Great Migration from the South to the North, citing pull factors such as the industrial boom in the Midwest and North, stifled European immigration flows resulting from World War I, and the proliferation of the railroad system, and push factors, such as the economically oppressive sharecropping system and the unpredictable racial violence that whites visited upon blacks with impunity (Grossman, 1991; Harrison, 2012; Lemann, 2011; Marks, 1989). The convergence of these macroeconomic factors created the necessary conditions to open the floodgates for the deluge of millions of America's bastards to migrate in and through every nook and cranny of this nation's borders and beyond in search of opportunity, place, and belonging.

The most popular receiving areas where black migrants ultimately resettled were booming mid-century industrial urban centers such as Philadelphia, New York, and Chicago, Detroit, Cleveland, and Los Angeles (William Edward Burghardt Du Bois, 1899; Grossman, 1991; Stewart E. Tolnay, White, Crowder, \& Adelman, 2005). In an age of industrialization, these cities offered an occupational opportunity structure that was exceedingly broader than that in the largely rural and agricultural context of the U.S. South. By no means did these destinations offer a level playing field for blacks, neither 
on an economic or social level, however they did signal a more expansive of horizon of opportunity based on the variety of employment opportunities, the seemingly inclusive and progressive public education system, and most importantly, the absence of Jim Crow's codes.

Although the big cities were by far the most popular final destinations for black migrants, there were also dozens of smaller areas that served as "layover points" along the course of the larger phenomena that came to become the African American Great Migration (Lewis, 1989; Marks, 1989; Trotter, 1985, 1991). In fact, recent studies show that stepwise-migration, a process by which migrants settle in one or more smaller receiving areas on a temporary basis along the way to settling in their final destination (Ravenstein, 1889), was also a common pathway for blacks who eventually ended up in major urban metropolises (Marks, 1989). Many of these layover areas were urban hubs in the South, such as Birmingham, AL, or Atlanta, GA, where black migrants would first move accumulate the additional skills, savings, and social capital necessary for the successful migration to larger urban arenas.

Extant Research on the African American Great Migration

In 2010, Isabel Wilkerson produced a masterful work of creative nonfiction entitled The Warmth of Other Suns. The exemplar journalistic account of the multifaceted emotional, spiritual, and psychological motivations, tribulations, and triumphs that African Americans experienced throughout the Great Migration, Warmth unearthed the macro-level "landscape of meaning" behind the movement that for too long went overlooked in the historical record. Wilkerson conducted over one thousand interviews 
with African Americans in five major receiving cities to capture the story, with its many variations of this, until then, untold slice of American history.

There is also a body of research within the social sciences, largely comprised of studies conducted by sociologists and economists, which focuses on the consequences of the African American Great Migration and the mechanisms that sustained the mass movement (Crowder, Tolnay, \& Adelman, 2001; Stewart E. Tolnay, Adelman, \& Crowder, 2002; Stewart E. Tolnay et al., 2005; Stewart E. Tolnay \& Crowder, 1999; White, Crowder, Tolnay, \& Adelman, 2005). The majority of these studies rely on data from the Integrated Public Use Microdata Series (IPUMS), a quantitative data source that aggregates person-level social and economic microdata from various U.S Censuses, and recent American Community Study (ACS) surveys. IPUMS data has made possible the empirical study of U.S. migration outcomes: How did those who migrated from the South during the Great Migration fare vis-à-vis their Northern counterparts (Stewart E. Tolnay, 2001)? What were the variations along dimensions of race and gender (Crowder et al., 2001)? How did marital status impact migrant's destination decision (White et al., 2005)? These and other outcomes-driven studies have had a tremendous impact on our understanding of the macro level social and economic consequences that the African American Great Migration has had on migrants, "natives", and receiving areas. However, the questions that have been asked to date are strictly limited by the data available to researchers. Further, the extant public use data sources have nearly been exhausted in terms of the reaching the limits of what more it can tell us about this phenomenon. As sociologist and demographer Stewart Tolnay aptly points out, "researchers have

\footnotetext{
1 "Natives" is a term used in the sociology of migration literature to refer to the white population vis-à-vis black, ethnic immigrant, or soon-to-be white European migrant populations.
} 
thoroughly mined existing data sources in their efforts to better understand which black southerners were more likely to pack up and head north during the Great Migration" and that "future progress on this issue will likely come from the innovative use of unanticipated data sources" (Tolnay, 2003, p. 213). While existing research has taken us far in terms of unpacking the outcomes of the Great Migration, we know very little about the pre-migration context of the sending communities, be it the migrants' place of birth or the "layover" cities. This becomes critically important as we begin to scale down our analyses from a general macro-level view towards a more nuanced set of examinations that account for the historically specific contexts, and their variations, within which the African American Great Migration emerged.

There is no doubt that sending communities experienced this era of exodus in a variety of ways. The extent to which Southern communities experienced economic devastation in the aftermath of the Civil War varied, the racial dynamics between blacks and whites articulated themselves differently across contexts, and the opportunity structures for blacks varied in meaningful and often detrimental ways from place to place. For example some states and regions were more heavily incentivized than others to meet convict labor quotas, some communities had a stronger penchant for committing acts of racial violence, while others offered more varied occupational possibilities in terms of the distribution of agricultural and industrial labor opportunities. Also, the notion of public education was just beginning to take root in the Deep South (J. D. Anderson, 1988), however most rural communities offered little to no schooling to black children.

Undoubtedly, the economic, political and social landscapes upon which the Great Migration emerged varied greatly, as did the motivations, aspirations, fears, and desires 
of the people who experienced it. The extant sociological literature on The African American Great Migration, mostly taken up by demographers, has made tremendous inroads in term of pushing our understanding of this phenomenon as a macro-level event. However, the tensions, contradictions, and counter-narratives of this transformation lie at the micro-level. As sociologist W.E.B. Du Bois (1898) asserts in his essay The Study of Negro Problems, "we must admit, for instance, that the study of the Negro in Massachusetts is not necessarily true of the Negro in Louisiana; that what was true of the Negro in 1850 was not necessarily true in 1750 ; and that there are many distinct social problems affecting the Negro".

Most underdeveloped, however, is our understanding of the way in which this perfect storm of social forces shaped and reanimated "the souls of black folk". The $20^{\text {th }}$ century was the period in American history when the concept of race was most highly contested, epistemologically, ontologically, and juridically. This is the era when the Supreme Court responded to questions of race and equality in America—birthing the hollow concept of a "post-racial" society—an era when the foundations of some of this country's most rigid "racial projects" were torn asunder, and when six million of the South's poor and weary black subjects voted with their feet, and left.

\section{The Case}

In this dissertation I examine a group of African Americans who, over the course of two generations, migrated into the coalfields of the Appalachian region of eastern Kentucky and who were subsequently displaced and resettled in urban centers across the U.S. throughout the Great Migration. This is the optimal case for this study. First, it is a 
quasi-natural experiment of an intergenerational mass migration of a group of black people who migrated during the course of the entire span of the Great Migration, between 1915 and 1970. While the first wave of black migrants (1915-1940) primarily originated from rural and semi-industrial cities in Alabama, the second generation migrants (19401970), who are the foci of this research, grew up in a spontaneously produced, geographically isolated environment that left little room for social, economic, political, or cultural variation in their upbringing and way of life. While no collective experience is monolithic, the elements of their community structured a way of being. Much of this social ontology is attributable to the nature of the company-owned town, which in this case was a product of almost complete social engineering.

I also chose this case because I am a third-generation descendent of this population; as my mother and father were both born and raised in Lynch, , and subsequently migrated to Long Island, NY where they raised my older brother and I. My earliest childhood memories include pilgrimages "back home" to the mountains as well as what seemed at the time to be exotic voyages to the Eastern Kentucky Social Club (EKSC) reunions. Both of my grandfathers, Major Brown and Thornton Davis, migrated from rural towns in Alabama to Lynch, , where they worked for a combined six decades "working the mines" for the United States Steel Corporation. My grandmothers, Leona Myrick (maiden name) and Mamie Davis (maiden name), were amongst the legion of unsung heroes of their era--the women who toiled at home while their husbands worked the mines to make ends meet. My grandmothers raised sixteen and eleven children, respectively, and bore the sole responsibility for running the household. The story of this generation of wives and mothers its own, independent work. Although my family 
connections were not my primary motivation for selecting this case, they definitely produced an overflowing well of energy, stamina, and joy in continuing on with the research — even when times got hard and the project seemed insurmountable. Lastly, the motivation behind this project came from the fact that the black experience in Appalachia is grossly understudied (Cabbell, 1980). As with any group of people, subjective experience varies greatly across space and time, and intersects across a spectrum of intersectionalities: race, gender, class, skin color, sexual orientation, religion, and regional affiliation to name a few. Therefore, in addition to its contribution to the discipline of Sociology, this study serves as a contribution to the fields of Southern Studies in particular and American Studies broadly.

\section{Defining the Source Area of Study}

According to the

Appalachian Regional

Commission (ARC),

Appalachia is comprised of

420 counties spanning

across thirteen states along

the inner-crust of the

eastern seaboard of the

United States, ranging from

southern New York to

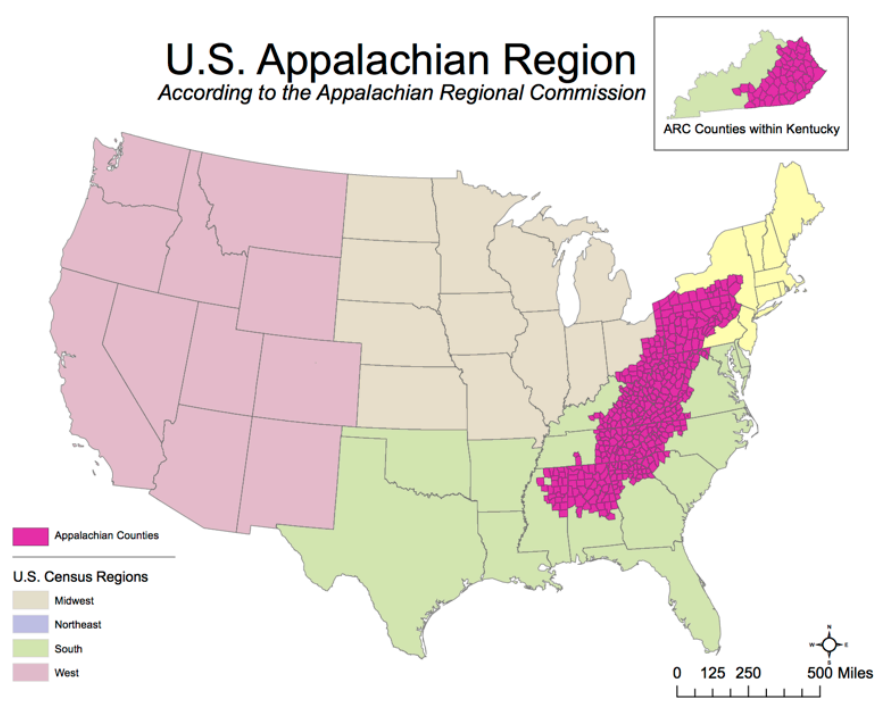

Figure 1. Map of U.S. Appalachian Counties 
northern Mississippi (www.arc.gov). Organized along the spine of a series of mountains, it cuts through three of the four U.S. Census regions. Included in Appalachia are some of the most economically distressed communities in the county, such as Beattyville, Kentucky, and Hamlin, West Virginia, as well as major metropolitan cities, such as Pittsburgh, Pennsylvania.

Notorious for the iconic "mountaineer" figure, the region is the ultimate representation of what America is not. He is backwards, superstitious, uneducated, amoral, uncitified and uncivilized. In her writings on the historical portrayals of Appalachian identity, Katie Algeo (2003) writes that popular writing renders people from the region as "silent and passive, objects of descriptions and scrutiny, who themselves contribute little to the popular conception of Appalachia." Much of what we have come to know about Appalachian culture is founded on depictions from nineteenth century travel diaries, literature, and popular magazines, such as Harper's and the Atlantic Monthly. America's internal Other, Appalachia, Algeo argues, "serves as a counterpoint to the idea of an increasingly unified and modern United States. Where the nation was progressive and industrial, Appalachia was backward and agricultural.” These tropes loom large in an American imagination, and play a significant role in how scholars and lay-people alike approach thinking about Appalachia.

However, there were tens of thousands of African Americans who first migrated from the rural South to the coalfields of West Virginia, Tennessee, and Kentucky—if only for one generation - as a first stop in the Great Migration (Lewis, 1989). Because of this peculiar layover, there are many African Americans across the country who still call Appalachia "home." Yet and still, as Edward Cabbell (1980) squarely put it thirty years 
ago, "black people in Appalachia are a neglected minority within a neglected minority" and that "their experiences are often so artfully clouded in myth and reality that they remain virtually invisible."

While popular representations of region most often depict the sub-region of Central Appalachia, which includes all of West Virginia and parts of Kentucky, Tennessee, and Virginia, we can see that Appalachia is immensely diverse. So diverse that, beyond a cultural reference, it is not a useful category if analysis for framing a community study such as this. Instead I define the source area of study for this dissertation at a granular and particular scale: three small coal-mining communities in Harlan County, Kentucky; namely Benham, Lynch, and Cumberland.

Figure 2. is a map of the Commonwealth of Kentucky. Classified by the U.S. Census as being in the Southern region of the U.S., we can see that Kentucky is an always already contested place. A border state laden with the historical legacies of the tug-of-war between

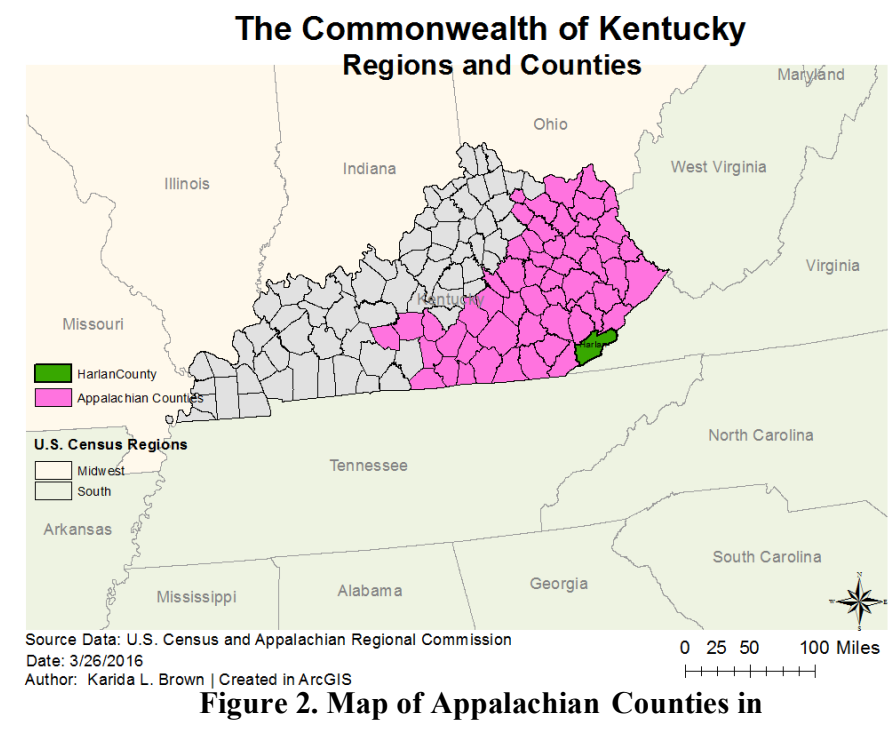
the Union and Confederacy, and a third of its eastern area consumed by the ever contested "Other" region of Central Appalachia, Kentucky is best described as a state with multiple personality syndrome. Notorious for its murderous labor battles in the 1970s, for which it earned the namesake "Bloody Harlan", this area stands out for other 
reasons that deem it a singular case. First, because Harlan County was one of the most prodigious bituminous coal producing locations in the nation, and as a result attracted the most well-endowed companies, such as United States Steel, Ford Motor Company, and International Harvester Corporation, to stake their claim in the region. As a result, the amount of capital infused into the then company-owned towns in Harlan County far exceeded that of other coal towns in surrounding counties; an economic inequality that surely impacted the social structures, hence the lived experience in that area.

\section{Project Aims}

In this dissertation, I am interested in processes of racialization and the (trans)formation of the racial self, and their relationship to social transformations at the macro and micro levels - from demographic transformations such as mass migration to structural transformations such as the desegregation of the local public school system. I pay particular attention to tracing the process of becoming African American-read along the grain of the Great Migration. While categories are useful for our own cognition, as they provide concepts and groups of signs and symbols that help us order "words and things", historicizing them and attending to their lumpiness is crucial to this type of sociological analysis.

An example. Early in my fieldwork, one participant articulated his generations' experience with blackness in terms of discursive transformations. Speaking of their experience matriculating through the segregated and desegregated school systems in Harlan County, he reflects:

If you look up there right there today in concrete it says Lynch Colored School...Its right there today. It's written out there: Lynch Colored School. See because we went 
through a transformation as to who we were. We went from Colored, to Negroes, to African-Americans... and Black. We went through all of those.

--Albert Harris | Born 1950 in Benham, | Resides in Sunrise, FL

Beyond the external meaning of these categories-Colored, Negro, African American, and Black — what did these various racial identifiers articulate in the subjectivities of those who were seized by those words? Broken down into a series of questions: How did this generation of black folks internalize these racial categories that were superimposed on them? How did they re-appropriate those categories within their own meaning systems? How did these words in turn structure their internal horizon of possibilities: their hopes, aspirations, fears, desires, etc.? And, connecting these smaller questions back to the question larger racial epistemic order, how did that series of discursive transformations impact the way in which this generation of black folks understood themselves as racialized subjects within the tabula rasa of the American body politic? To examine these most interior questions of racialized subjectivity, I trace the configuration and rearticulation of signs, symbols, and structures that order the meaning systems within the black social world.

W.E.B. Du Bois (1903) prefaced his masterpiece The Souls of Black Folk with the following inscription:

HEREIN LIE BURIED many things which if read with patience may show the strange meaning of being black here at the dawning of the Twentieth Century. This meaning is not without interest to you, Gentle Reader; for the problem of the Twentieth Century is the problem of the color line. I pray you, then, receive my little book in all charity, studying my words with me, forgiving mistake and foible for sake of the faith and passion that is in me, and seeking the grain of truth hidden there. I have sought here to sketch, in vague, uncertain outline, the spiritual world in which ten thousand thousand Americans live and strive. 
It was 1903 when Du Bois published Souls. At the time, over ninety percent of black people in America lived in the U.S. South; primarily the rural enclaves of the Deep South, where the thick stench of slavery's aftermath choked the fragrance of Life, Liberty and Happiness that this country's newly freed slaves yearned to inhale. Where Souls reveals the "strange meaning of being black at the dawning of the Twentieth Century", this dissertation traces that meaning in its many transformations in-flux, along the variety of social transformations of the Twentieth Century.

In this passage Du Bois famously augured that "the problem of the Twentieth Century is the problem of the color line." Following in a Du Boisian sociological tradition, I illuminate dualities and tensions that lie between the unfortunate yet selfevident truth of his proclamation - that the dehumanizing and oppressive forces of the color line would persist to shape the black experience for the Century to come--and the awe-inspiring, improvisational assertions of self-making, cultural expression, and pride that burst within black folks" "spiritual world" in spite of their condition — the many ways in which they asserted to themselves that their black lives matter.

\section{Chapter Overview}

Chapter One, "The Negro Problem in America" lays out the analytical framework that motivates the empirical chapters of this dissertation; defining concepts, analytical frames, and the philosophical underpinnings of my analysis. Chapter Two, "Turning the Screw of Interpretation on the Archive", deals with the methods; the data, analysis, praxis, ethics, as well as problematics that I confronted in designing a

\footnotetext{
${ }^{2}$ A version of this chapter is published in the Spring 2016 issue of Southern Cultures
} 
sound sociological study of black subjectivity. I also address issues of data management and archive that loom large throughout this project, albeit at a meta-level. The next five chapters are empirical. They are broken into "scenes of subjectivity", to play on Saidiya Hartman's (1997) phrase, a are structured to highlight the tensions, dualities, and the changing same of social transformations in and around the color line. The first scene, chapters three and four take up the black migration into of the coalfields of eastern Kentucky. Chapter Three, "The Great Migration Escape", provides a historical analysis of the in-migration, from 1915 to 1940, from Alabama to eastern Kentucky, and establishes what Hirschman and Reed (2014) call a "formation story"-historical sociological analyses that "explain how social things come to be stable enough to force or be forced" and thus "establish historical boundaries past which forcing-cause claims likely will not travel." This chapter illuminates the conditions under which this particular iteration of the African American Great Migration emerged, including the pre-migration context from which they originated and the racial landscape from which they exited. Chapter Four, "Home", introduces the second generation of black migrants represented in this study--the generation who are the foci of this research. Through a phenomenological analysis, I interrogate the "landscape of meaning" upon which this generations' Self emerged, both as racialized subjects and as coal miners' sons and daughters. This chapter reveals the tensions between the progress of moving out of the throws of the Deep South to the company towns of eastern Kentucky and the durability of the social force of the veil. Chapter Five, "The Colored School”, examines the black school in the segregated U.S. South as a distinct cultural formation. While the extant sociological literature focuses on Brown v. Board of Education and its aftermath, this 
chapter focuses on the era that goes nearly wholly overlooked: the "colored school". Through an examination of the political context through which the colored school emerged and an analysis of the pedagogical, institutional logics, and lived experience of the system, I answer the following questions (1) "what was the colored school?" and (2) what role did it play in shaping the worldviews and habitus of black children?" Chapter Six, "The Hidden Injuries of School Desegregation"3 examines the impact of the process of school desegregation on African American subjectivity. In this chapter, I reveal the hidden injuries of school desegregation and the ways in which Kentucky's coal camp blacks construct and refashion their collective memory around the loss of "their" school. Scene three takes up collective experience of loss, mourning, and memory that often accompanies diaspora. Chapter Seven, "Gone Home: Race and Roots through Appalachia" traces the acute out migration of the population of young working-age blacks out of Harlan County, to urban cities all across the country. This chapter identifies the mechanisms that undergirded this mass out-migration within the broader context of the larger African American Great Migration, it also attends to the simultaneous decline of the once booming coal towns of Harlan County, . I show how the black diaspora from these communities "invented traditions", rituals, and performances to reinscribe their sense of home and belonging to Appalachia that emerged within the context of industrial ruination and erasure.

\footnotetext{
${ }^{3}$ A version of this chapter is forthcoming in the American Journal of Cultural Sociology.
} 


\section{CHAPTER ONE}

\section{The Negro Problem in America}

The question is simply this: can a negro whose ancestors were imported into this country and sold as slaves become a member of the political community formed and brought into existence by the Constitution of the United States, and as such become entitled to all the rights, and privileges, and immunities, guaranteed by that instrument to the citizen...?

--Chief Justice Roger B. Taney, 1857 | Scott v. Sandford

All persons born or naturalized in the United States, and subject to the jurisdiction thereof, are citizens of the United States and of the state wherein they reside. No state shall make or enforce any law which shall abridge the privileges or immunities of citizens of the United

States; nor shall any state deprive any person of life, liberty, or property, without due process of law; nor deny to any person within its jurisdiction the equal protection of the

laws.

$--14^{\text {th }}$ Amendment of the United States Constitution, 1868

The argument also assumes that social prejudices may be overcome by legislation, and that equal rights cannot be secured to the negro except by an enforced commingling of the two races. We cannot accept this proposition. If the two races are to meet upon terms of social equality, it must be the result of natural affinities, a mutual appreciation of each other's merits, and a voluntary consent of individuals...this end can neither be accomplished nor promoted by laws which conflict with the general sentiment of the community upon whom they are designed to operate.

--Chief Justice Henry Billings Brown, 1896 | Plessy v. Ferguson

Before we can begin to study the Negro intelligently, we must realize definitely that not only

is he affected by all the varying social forces that act on any nation at his stage of advancement, but that in addition to these there is reacting upon him the mighty power of a peculiar and unusual social environment which affects to some extent every other social force. In the second place we should seek to know and measure carefully all the forces and conditions that go to make up these different problems, to trace the historical development of these conditions, and discover as far as possible the probable trend of further development. 


\section{Introduction}

This dissertation is about race. This is not constituted simply because of the fact that the social group who are the subject of this research - the black men and women who migrated throughout the Appalachian coal towns through eastern Kentucky—are black, but because my primary category of analysis is the formation and transformation of their racialized subjectivity. This is largely a question of the racial self. In my analysis I seek to take up race - a socially constructed category of analysis - and racialization - the ongoing process of (trans)formation of the racial subject - towards an interpretation that is both structural and phenomenological. Using this framework I approach the racial self as a refraction projected through the interfaces of the State, public opinion, everyday social interaction, and the Self; addressing the questions that loom large in social thought considering the human condition: Who am I? and Who are We? - questions that situate the self in relation to society (Cooley, 1992; Descartes, 1960; Mead, 1934) — and for the racialized being, What am I? —an ontological question of humanity (Alcoff, 1999; Bogues, 2012; Césaire, 2000; Fanon, 1967).

Sociologists have long accepted that "the social" is constructed (Berger \& Luckmann, 1991; Du Bois, 1940; Hirschman \& Reed, 2014; Mead, 1964; Reed, 2011). Whether life worlds, group identities, political entities, ideas, institutions, nations; social things become real through the ongoing process of social construction, of assemblages of objects, people, ideas, and institutions, and, as Foucault (Foucault, 2002) aptly coined, of "words and things". The Self too is a social construction. Sociological theorists of the Self argue that one only comes to know him or herself through social interaction, communication, and mutual recognition (Cooley, 1992; Du Bois, 1903; Mead, 1964). 
Beginning with early affirmations of our "I", from infant-parent interactions, to interfamilial interactions, to those in-and-between societies, we come to know who we are through the eyes of others. Through social interaction we not only learn who "we" are, but also the contours and boundaries of who that "we" entails. In other words, in the process of coming to understand our subjective Selves--the "I" and the "we"-we also learn who "they" are. As a racial state, the emergence of American identity is predicated on this we/they binary, which defines those who belong and those who fall outside of the original intent of "who we are". This is the settler colonial project. In the U.S., the ultimate Other is constructed upon the body of the Negro ${ }^{4}$.

The American mythos of democracy, freedom and liberty collapses on the Negro problem (Douglass, 1852; Patterson, 1982). As a juridical formation, her subjecthood has been stately problematic since the formation of the Union in 1776 up until the Civil Rights Act of 1964. She has been even more menacing as a social being in American society: an American citizen ${ }^{5}$ at the margins, the uncounted and unintended. She is what Mae Ngai (2014) calls an "impossible subject, a person who cannot be and a problem that cannot be solved." This is because her subjecthood is foundational to the makeup of the American colonies that later became the United States of America, while her personhood remains unassimilable (Glazer, 1993). Continually defined in terms of lack and not-ness by state and society, the Negro in America has always been framed as a problem.

\footnotetext{
${ }^{4}$ Indigenous peoples are also systematically Othered in the American psyche, however this othering process occurs through dispossession, genocide and historical and cultural erasure, whereas the Negro is Othered through hypervisibility, surveillance, policing, public degradation, and spectacular violence.

${ }^{5}$ As of 1868 with the ratification of the Fourteenth Amendment to the U.S. Constitution.
} 


\section{Les Mots et Les Choses: Social Categories and Racialized Subjectivity}

Race is a category of analysis, a lived experience, and a historical fact. Thus, a robust sociological analysis of the phenomena requires a certain analytical pluralism in order to attend to the myriad of assembleges that articulate "race" as a primary matter of concern, and to allow for an interpretation that can attend to those assembleges within their own historical contexts. Most would agree that such sensitivities are necessary for the analysis of any social construct. However, where we fall short in our imperative to "reassemble the social" (Latour, 2007) is the careful attention to the historicity of the process of social construction itself (Foucault, 2012; Hirschman \& Reed, 2014; Reed, 2011; Somers, 1996). Although we acknowledge the fact that social categories are historically constructed, we elide the fact that the meanings of "words and things" are bounded in space and time, leading us to tacitly endow a stable and portable quality upon social categories that is not there.

My aim in this dissertation is to put forth an analysis of race at the closest, most interior level — subjectivity - a concept that I will expand on in the second half of this section. I am specifically interested in the ways in which African American subjectivity emerged and transformed over the various racial landscapes of the pre and post Civil Rights era in Twentieth Century America. I trace the meaning of being black in America by observing the "structure of feeling" (Williams, 2006) of a group of black folks who participated in a specific iteration of the African American Great Migration. With a history rooted the post-reconstruction Deep South, and an intergenerational journey through various promised lands that signaled progress, liberty, and full incorporation into the American citizenry, their stories offer unique insight into the perils, hopes, fears, 
aspirations, and worldviews that shaped the black racial self during this epoch and transformative period in this country's history.

In order to carry out such an analysis it is most important to interrogate the historicity of the category "African American." As the quote in the Introduction by my participant Albert Harris illuminates, there is much to that name. As he reminds us, his generation — black children of the 1940s and 50s—went from "Negro, to Colored, to Black, to African American" all in one generation. We can not, therefore, take for granted that those discursive transformations did not bear a great deal of meaning for black folks of his generation in terms of how they understood themselves as members of their local communities and as citizens of the United States of America. The symbolic meaning of these names are bounded in time and place and have been pierced, ruptured, shaped and transformed by events, politics, encounters, songs, and movements; dialectically shaped by and shaping black subjectivity in this era of social, political, economic transformation.

For example, as we will see in Chapter Four, one song produced in 1968 transformed the symbolic order of calling oneself "Black" - because amongst all of the political turmoil and black struggle, James Brown suddenly gave us permission and language to be at the same time black and proud. Prior to that song, calling one's fellow Negro "black" were considered fighting words. Research participant Virginia Ward remembered how Say it Loud! emancipated her from her unconscious disassociation of blackness and beauty. Speaking of the first time she heard the song she recalls that, "it was a transformation. I got to the point where I could actually say it. I'm Ba-baba...Black!...and I'm proud! I was okay after that.” Throughout the dissertation, I trace transformations in African American subjectivity, some subtle like the latter example, 
while others structural and explicit, such as the desegregation of the U.S. public school system - a moment that I argue in Chapter Six, inaugurates the "African American" subject.

From the perspective of historical sociologists, one could say that my aim is to make causal claims through the analysis of becoming. How did the African American racial self-come to form itself in the Twentieth Century? And in moments of transformation, what lead to the reconfiguration of those things? This form of causality is not the same as what positivists hold on to in terms of X causes Y. I instead make claims on the terms upon which $\mathrm{X}$ - such as mass-migration, discursive transformations, school desegregation, or displacement—and Y-African American subjectivity—came to possess such social force to act and be acted upon in a particular time and place. In these way, this analysis is rooted in what Hirschman and Reed (2014, p. 268) call formation stories, what they refer to as "explanatory accounts of how social kinds are shaped, reshaped, or brought into being; in contrast to forcing causes, these stories take as their points of reference the nonfixedness of social entities, the eventful-ness of social life, the emergence of social entities from processes of assemblage, and the dependence of such assemblage and nonfixedness on representation." Ultimately, the explanatory value of formation stories exists in their ability to "explain how social things come to be stable enough to force or be forced" (Hirschman \& Reed, 2014, p. 260). Throughout the chapters of this dissertation, we will peer into how these categories - Colored, Negro, Black, African American, and yes, Nigger - came to "force or be forced" on what ultimately became "African American" subjectivity. 
I adopt Sherry Ortner's (2005) dynamic definition of subjectivity that she put forward in her essay Subjectivity and Cultural Critique, where she states "by subjectivity I mean the ensemble of modes of perception, affect, thought, desire, and fear that animate acting subjects. But I always mean as well the cultural and social formations that shape, organize and provoke those modes of affect thought, and so on." In her formulation, subjectivity is produced, shaped, and transformed through an ongoing process of what Anthony Giddens (1984) termed "structuration"; that is the ongoing dialectic between structure and agency, through which structures create behaviors and subjects' behaviors create structures.

The theorization of subjectivity outlined by scholars such as Ortner, Sewell, and Giddens departs from that of social theorists such as Bourdieu and Foucault in that the subject is a reflexive "knowing" entity. For example, Bourdieu's (1990) formulation of subjectivity—habitus—is defined as:

systems of durable, transposable dispositions, structured structures predisposed to function as structuring structures, that is, as principles which generate and organize practices and representations that can be objectively adapted to their outcomes without presupposing a conscious aiming at ends or an express mastery of the operations necessary in order to attain them. Objectively regulated and regular without being in any way the product of obedience to rules, they can be collectively orchestrated without being the product of the organizing action of a conductor.

What is important to highlight here is that Bourdieu's formulation the system of habits that orient human action are unconscious while robust are inattentive to the subject's ability to act outside of the set of scripts available to him. This leaves little room for the consideration of inner imagination, aspiration, desire, rupture, transformation and change. Foucault's (1977) theory of the subject, as articulated in Discipline and Punish lands us 
in the same predicament, as his is a theory of subject formation, not of humanism.

Therefore, he is interested in the ways in which structures, institutions, and discursive formations construct the subject.

However the examination of racialized subjectivity requires the social observer to make plain the material conditions under which the social forces of racism, prejudice, and dehumanization manifest themselves in and on the black body as well as the ways in which the racialized subject makes herself within the constraints of racial subjugation. Philosopher Linda Alcoff $(2005$, p. 183) frames the question of racialized subjectivity as "experienced selfhood" and "the everydayness of racial experience", arguing that "objectivist approaches that define race by invoking metanarratives of historical experience, cultural traditions, or processes of colonization and that take a third-person perspective can be inattentive to the microinteractions in which racialization operates, is reproduced, and is sometimes resignified." For the scholar wishing to engage with the observation and analysis of racialized subjectivity she urges us to hold on to the notion that "the epistemically relevant point here is that the source of racializations, or at least one important source, is in the microprocesses of subjective existence (Alcoff, 2005, p. 185)." Du Bois (1903) describes this as the "atmosphere of the land, the thought and feeling, the thousand and one little actions which go to make up life." In the essay "Of Masters and Men" he expounds on human experience in the Jim Crow South:

It is, in fine, the atmosphere of the land, the thought and feeling, the thousand and one little actions which go to make up life. In any community or nation it is these little things which are most elusive to the grasp and yet most essential to any clear conception of the group life taken as a whole. What is thus true of all communities is peculiarly true of the South, where, outside of written history and outside of printed law, there has been going on for a generation as 
deep a storm and stress of human souls, as intense a ferment of feeling, as intricate a writhing of spirit, as ever a people experienced."

This is the analytic frame, and philosophical underpinning that guides my analysis in this dissertation. While my empirical examination stays close to these microprocesses and interactions, much like Du Bois analyses of subjectivity (Du Bois, 1903, 1940), it is embedded in the global structure of race and racialization that was inaugurated by modernity itself.

\section{Towards a Supra-national Interpretation of Race and Racialization}

Racialization is a global political project (Du Bois, 1940; Mills, 1997; Winant, 2009; Wynter, 1995). Dating back to the dawn of modernity, since the encounter in 1492 , the European mission of global expansion required the wholesale classification and subjugation $^{6}$ of peoples. What I mean by racialization is the process by which the taxonomy of racial categories are produced, ordered, and seared into the epistemological structures of society. Its outcome is the durable, yet variant, conception of "race" as a reliable motivator of social thought and action. So universal in the modern mind, race is often taken-for-granted as a real thing with durable boundaries and characteristics. This could not be farther from the truth. As groups and peoples are always in a state of becoming, racial categories are always subject to reconfiguration, and what we know, or come to accept about race and racialized groups shifts in the public mind. However, as the trajectory of our ways of knowing are structured upon what Foucault (Foucault, 2002) called epistemes — " the historical a priori that grounds knowledge and its discourses and

\footnotetext{
${ }^{6}$ Subjugation includes all technologies employed towards the wholesale domination of peoples; this includes but is not limited to enslavement, extermination, dispossession, alienation, and expulsion.
} 
thus represents the condition of their possibility within a particular epoch"transformation at the epistemological level is incredibly difficult. We will see through the empirical chapters of the dissertation. Although the racial landscape changes and broadens as the generations progress through space and time-i.e., with time and movement lynchings become less and less of a threat, blacks begin to gain access to a broadening occupational structure, property ownership becomes a possibility, the military and schools become integrated-yet the reality of anti-black racism remains the changing same.

In an effort to steep my phenomenological analysis of racialized subjectivity in structure my intent in this section is to make clear the architectural design upon which the modern conception race hinges. In speaking of the global project of racialization, philosopher Charles W. Mills (1997) argues:

By virtue of their complete nonrecognition, or at best inadequate, myopic recognition, of the duties of natural lay, nonwhites are appropriately relegated to a lower rung on the moral ladder. They are designated as born unfree and unequal. A partitioned social ontology is therefore created, a universe divided between persons and racial subpersons, Untermenschen, who may variously be black, red, brown, yellow-slaves, aborigines, colonial populations - but who are collectively appropriately known as "subject races".

In this way, in what Foucault (2002) calls our present modern episteme, humanity exists in the Western mind not as a discrete category, but instead along a continuum. In the nation state, these variations of the human manifest itself in the category of the citizen. Mills articulates this in the passage above in his conceptualization of "subject races", in that what becomes important to lived experience of the racialized being in the nationstate is that a citizen has rights, a subject has privileges. While the former has the right to 
make legitimate claims on the State, the latter exists in perpetual precarity, as privileges can legitimately be taken away as easily as they are given.

\section{On Citizenship and Race}

British sociologist T.H. Marshall defines citizenship as "a status bestowed on those who are full members of a community. All who possess the status are equal with respect to the rights and duties with which the status is endowed. There is no universal principle that determines what those rights and duties shall be, but societies in which citizenship is a developing institution create an image of an ideal citizen against which achievement can be measured and towards which aspiration can be directed" (Bottomore \& Marshall, 1992, p. 18). Presupposed in this definition is an undesirable "Other" that is both different from and constitutive of the ideal Citizen.

As the Other can and often does exist as the "enemy within", access to citizenship tends to map on to the racialized continuum of humanity. In his analysis of the inherent inequality of citizenship in the context of turn of the century England, Marshall marks this distinction by what he calls formal and substantive citizenship. Formal citizenship is defined as membership of a nation-state, whereas substantive citizenship encompasses the latter as well as the civil, political and social elements of citizenship outlined by Marshall (Bottomore \& Marshall, 1992; Ceuppens \& Geschiere, 2005; Geschiere, 2009; Glenn, 2011). The central question of substantive citizenship is who rightfully belongs and who does not (Bosniak, 2008; Geschiere, 2009). Castles and Davidson (2000, pp. 118-119) advance this notion in their analysis of the relationship between citizenship and "racial subjecthood": 
"People in this category have an insecure position and their social citizenship is not guaranteed. Second, there are minority groups particularly susceptible to marginalization as a result of weak legal position, severe racial stigmatization, a lack of human capital resulting from past discrimination, and specific historical conditions of conflict. These groups include indigenous peoples in North America and Australia, African Americans in the USA, Afro-Caribbean's and South Asians in Britain, and asylum-seekers in Europe. Members of such groups are very likely to suffer social exclusion, and therefore do not enjoy social citizenship".

How do the consequences of racialization complicate notions of citizenship and national identity? As the project of modernity catches up to itself Western nation-states are faced with the consequences of colonialism and the slave trade, and the racialized subject emerges as a social problem in the national discourse, as she transforms from mere chattel and emerges as the commodity who speaks (Moten, 2003). Whether the Algerian in France, the Jamaican, South Asian, or Pakistani in Britain, the Surinamese and Indonesian in the Netherlands, or Africa's posterity in America, the racialized subject, although a sheer product of modernity, is framed by the State as a problem. She is to be defined, quantified, ordered, surveilled, disciplined, and punished by the contours of the State's ascriptive articulation of her subjecthood.

Therefore, if we are to begin to understand the subjectivity of the African American, we must understand his racialization. In the following section, I analyze a set of founding federal cases and documents grappling with the Negro problem in America. I focus my analysis to a close reading of four federal-level documents that concerned the position of the Negro in society during the period of nation-building in the U.S; namely James Madison's Federalist Paper no. 54 (1788), Chief Justice Taney’s opinion in Scott v. Sandford (1857), the Fourteenth Amendment of the U.S. Constitution (1868), and Chief 
Justice Henry Billings Brown's opinion in Plessy v. Ferguson (1896). There are of course, hundreds of other state and local level cases and documents that could bolster this analysis, however in the words of U.S. Supreme Court Chief Justice Roger B. Taney (1857), "it would be impossible to enumerate and compress in the space usually allotted to an opinion of a court the various laws, marking the condition of this race which were passed from time to time after the Revolution and before and since the adoption of the Constitution of the United States." While the empirical chapters of the dissertation take up the phenomenological dimensions of race, the following analysis of examines the Negro as a juridical formation. While the State and the Law by no means completely determines the life, experiences, and subjectivity of the Negro in America, they are illustrative of the deep-seated ways in which the global political project of race and racialization is sedimented into the American ethos, and how anti-black racism is takenfor-granted everyday American life. As my participants will tell you when explaining the mores of living in a Jim Crow society, "its just the way it was"; just as it was for their parents and their parents' parents although on altogether different racial landscapes. Therefore, this reading of the State and the Law can instead be read as a symptom of society, and a product of the American political project of white supremacy.

\section{What is the Negro: Subject or Citizen?}

When we get to the moment of state formation in the $18^{\text {th }}$ and $19^{\text {th }}$ centuries, the U.S. is faced with grappling with the question that had for so long gone unaddressed: And what of the Negro? As Orlando Patterson (1982) rightly points out, the Negro is particularly vexing in the U.S. context because it is a settler nation, in which the "racial subjects" were contained through extermination, enslavement, or reservation in order to 
allow white colonizers' to inscribe their American identity through nonhistorical autochthonous claims to the land ${ }^{7}$. However, the wholly excluded social position of the Negro became a major issue in the wake of nationalization.

In the years leading up to the ratification of the U.S. Constitution, much of the disagreements concerned the subjecthood of the black population: Were the enslaved property or human beings? How would they be counted for legislative representation, for taxation?: If they were truly property, then they should be taxed in the same way as oxen, cattle, and bales of cotton. However, if they were in fact human beings, surely they should count towards state representation. Persuading the Southern slaveholding states to vote to ratify the U.S. Constitution hinged on this matter. In their popular leaflets known as the Federalist Papers, statesmen James Madison, Alexander Hamilton, and John Jay advocated for the ratification of the U.S. Constitution. In a carefully maneuvered argument, Madison walked his audience through how the constitution would handle the Negro problem:

The federal Constitution, therefore, decides with great propriety on the case of our slaves, when it views them in the mixed character of persons and of property. This is in fact their true character. It is the character bestowed on them by the laws under which they live; and it will not be denied, that these are the proper criterion; because it is only under the pretext that the laws have transformed the negroes into subjects of property, that a place is disputed them in the computation of numbers; and it is admitted, that if the laws were to restore the rights which have been taken away, the negroes could no longer be refused an equal share of representation with the other inhabitants.

Madison is clear - the Negro is "transformed" into "subjects of property" solely by the law, and with the swift legerdemain of the pen, her humanity could be restored.

\footnotetext{
${ }^{7}$ Settler nations like South Africa and Australia faced similar problems.
} 
However, for the purposes of coming to an agreement, Madison suggested that they split the baby. He offers the most ridiculous solution:

Let the compromising expedient of the Constitution be mutually adopted, which regards them as inhabitants, but as debased by servitude below the equal level of free inhabitants, which regards the SLAVE as divested of two fifths of the MAN.

And with that the Negro officially became a little more than half a person in the eyes of American society.

Even at the cusp of universal emancipation, the "Negro problem" was evident. Dred Scott sued for his and his family's freedom on the premise that they were living in a state where slavery was illegal. The incongruence of free and slave states complicated the matter of Negro subjecthood under the rubric of a federal union. The Dred Scott decision would be the first case to reach the U.S. Supreme Court to address the question of Negro citizenship. Was the Negro subject of citizen? In his final decision, Chief Justice Taney was clear:

We think they are not, and that they are not included, and were not intended to be included, under the word "citizens" in the Constitution, and can therefore claim none of the rights and privileges which that instrument provides for and secures to citizens of the United States. On the contrary, they were at that time considered as a subordinate and inferior class of beings who had been subjugated by the dominant race, and, whether emancipated or not, yet remained subject to their authority, and had no rights or privileges but such as those who held the power and the Government might choose to grant them.

Taney's opinion lies on his interpretation of the "original intent" of the authors of the United States Constitution. He later re-emphasizes the point of original intent when 
he states: "But it is too clear for dispute that the enslaved African race were not intended to be included, and formed no part of the people who framed and adopted this declaration." It is important to note here that contrary to Madison's theory that the Negro's subjecthood is purely a matter of the letter of the law, Taney is also arguing that sentiment and public opinion also matter in how the law is interpreted and extended. We see this later in his opinion where he agues:

They had for more than a century before been regarded as beings of an inferior order, and altogether unfit to associate with the white race either in social or political relations, and so far inferior that they had no rights which the white man was bound to respect, and that the negro might justly and lawfully be reduced to slavery for his benefit. He was bought and sold, and treated as an ordinary article of merchandise and traffic whenever a profit could be made by it. This opinion was at that time fixed and universal in the civilized portion of the white race. It was regarded as an axiom in morals as well as in politics which no one thought of disputing or supposed to be open to dispute, and men in every grade and position in society daily and habitually acted upon it in their private pursuits, as well as in matters of public concern, without doubting for a moment the correctness of this opinion.

As Taney clarifies, the Negro's inferior status was not only a matter of the law, but "regarded as an axiom in morals" - a matter of the way things ought to be- - "as well as in politics"- the way that society is governed. Accepting the Negro's condition as a moral imperative gives a new level of authority to racial subjugation, one that can be considered beyond the control of man, because it declares the Negro's inferiority as a state of nature. While other races have some ability to assimilate, the Negro's history with enslavement is marked on the body. Using the reasoning that his ancestors were 
property has been circulated throughout time to justify why the Negro is and deserves to be kept down ${ }^{8}$.

This logic goes all the way back to Las Casas when he deemed that the African did not have a soul and was therefore suitable for slavery where the Indians were salvageable. This logic has metastasized into the letter of the law and seeped into the hearts and minds of the public. This is the global "knowledge culture" (Somers, 1996) of the western epistemological order.

At the national level, this way of knowing conditioned a dual American society, one consisting of citizens - those who were entitled to duties and rights from the State, and subjects - those who remained in a constant state of precarity. The State gives to its subjects but owes them nothing; the subject may be tolerated but does not belong. In the pre-emancipation moment, no one was more emblematic of the racial subject than the Negro. Taney draws this line towards to the close of his legal opinion in Dred Scott vs. Sandford:

Words could hardly have been used which more strongly mark the line of distinction between the citizen and the subject--the free and the subjugated races. The latter were not even counted when the inhabitants of a State were to be embodied in proportion to its numbers for the general defense. And it cannot for a moment be supposed that a class of persons thus separated and rejected from those who formed the sovereignty of the States, were yet intended to be included under the words "free inhabitants," in the preceding article, to whom privileges and immunities were so carefully secured in every State.

Even after the ratification of the $14^{\text {th }}, 15^{\text {th }}$, and $16^{\text {th }}$ amendments, which abolished slavery and bestowed the rights of citizenship to all people born the U.S., the moral

\footnotetext{
${ }^{8}$ I was once property.
} 
philosophy of how things ought to be regarding variety of humankinds pervaded this country's legal thinking. White supremacy was embedded into the political structure as well as in the American habitus. The indexical "us" and "them" racial epistemology was apart of what it meant to understand oneself as American, or not so much. In the 1896, nearly twenty years after the ratification of the Fourteenth Amendment, came the Plessy v. Ferguson Supreme Court case, which challenged the separate but equal doctrine that mandated racial segregation in public spaces. In the Court's final decision, Chief Justice Henry Billings Brown opined:

The argument also assumes that social prejudices may be overcome by legislation, and that equal rights cannot be secured to the negro except by an enforced commingling of the two races. We cannot accept this proposition. If the two races are to meet upon terms of social equality, it must be the result of natural affinities, a mutual appreciation of each other's merits, and a voluntary consent of individuals...this end can neither be accomplished nor promoted by laws which conflict with the general sentiment of the community upon whom they are designed to operate.

Chief Justice Brown offers an insightful intervention in his legal opinion. Racial subjugation was not to be considered solely a matter of the law, it one of society. The sheer disdain and contempt for the Negro, whether subject of citizen, would not be overcome by legislation but through soul and sentiment of mainstream Americans. This is the historical context through which African American subjectivity emerged.

\section{Emergence of the Racial Self: African American Subjectivity}

The ontological societal position of the black subject in America is that of social death. In his exegetical comparative analysis of slave societies, sociologist Orlando Patterson (1982) describes social death as a state of abject alienation in which the 
enslaved being exists within the broader structures of society. The cultural mode of representing social death, which Patterson calls intrusive social death, is predicated on the notion that the enslaved was "ritually incorporated as the permanent enemy on the inside" and that he "could not belong because he was the product of a hostile, alien culture." In this formulation, the Negro in America - the enslaved - is incorporated into society as a subhuman. Their entire existence revolves around their master, rendering the socially dead incapable of garnering mutual recognition, sympathy, or respect from broader society. As an asocial being, the enslaved is constructed through a state of "institutional marginality"; characterized by the combined totality of natal alienation, dishonor, and domination. Most significant to the analysis of the emergence of Negro subjectivity in the U.S. is this concept of natal alienation, which Patterson argues excises the enslaved subject from its "right to belong to any legitimate social order". Patterson's formulation makes plain in a significant way the historical conditions under which Du Bois' tripartite conceptualization of black subjectivity — namely second sight, double consciousness, and twoness-emerged. Du Bois (1903) articulates this theory in Souls, where in one of his most cited passages he powerfully describes what he called "the strange meaning of being black in America":

a sort of seventh son, born with a veil, and gifted with second-sight in this American world, - a world which yields him no true self-consciousness, but only lets him see himself through the revelation of the other world. It is a peculiar sensation, this double-consciousness, this sense of always looking at one's self through the eyes of others, of measuring one's soul by the tape of a world that looks on in amused contempt and pity. One ever feels his two-ness,an American, a Negro; two souls, two thoughts, two unreconciled strivings; two warring ideals in one dark body. 
Specific to the U.S. context, the complex, contradictory structure of coexisting with the living dead is what Patterson situates as the "final cultural dilemma posed by the problem of slavery" - a problem that emerged into what W.E.B. Du Bois keenly identified as the problem of the $20^{\text {th }}$ century-the color line. The grumblings of the African American Great Migration began at the turn of the Twentieth Century, almost half a century after this country's enslaved population was emancipated. This was a social movement during which America's black folk began the long journey in search of a place in this country. Place in the sense of geographical terms: a place to live and work, but also a place in terms of citizenship, belonging, and inscription into the social heritage of America. Less cited, but just as significant to Du Bois' theory of Double Consciousness is his expostulation on the plight of the American Negro; his quest and striving towards mutual recognition of her full humanity, a "social resurrection" if you will. In the paragraph following his exposition of the theory of Double Consciousness he writes:

The history of the American Negro is the history of this strife, - this longing to attain self-consciousness, to merge his double self into a better and truer self. In this merging he wishes neither of the older selves to be lost. He would not Africanize America, for America has too much to teach the world and Africa. He would not bleach his Negro soul in a flood of white Americanism, for he knows that Negro blood has a message for the world. He simply wishes to make it possible for a man to be both a Negro and an American, without being cursed and spit upon by his fellows, without having the doors of Opportunity closed roughly in his face.

Between these two powerful paragraphs Du Bois reveals the inherent tension in the formation of black Self. It is both "forced" by the repeated confrontation with misrecognition, misunderstanding, hatred and oppression, and at the same time a "forcing 
cause" of untiring hope, striving, improvisation, and soulful cultural expression all within as Du Bois keenly points out, "one dark body". We hold on to these tensions and dualities throughout the empirical chapters of this dissertation.

\section{Conclusion: A Social Resurrection}

So what then can be said about those who struggled to awaken themselves out of the alienated, disoriented, marginalia of slavery? Those blacks who are two, three and four generations removed from slavery embarked on one of the most profound social movements in American history; not only in their mass out-migration from the South to the North, but in their incessant striving for social resurrection. This endeavor can largely be read as a collective re-making of the self, the ultimate auto-poetic project. We only need to turn to the literary works of Richard Wright, Langston Hughes, and Toni Morrison, the soulful lyrics of Sam Cooke, James Brown, Tina Turner and Nina Simone, or the art of Aaron Douglas, Jacob Lawrence, or Gordon Parks to sense the inextricable linkages between migration and the black experience throughout the $20^{\text {th }}$ century.

The first group of blacks who initiated the migration were incredibly brave. They had no blueprint, no established network, and the country was not yet sure about how it would handle its "impossible subjects". In this second wave of The African American Great Migration—in the post-emancipation moment—blacks left under different "conditions of exit" (Portes \& Böröcz, 1989). Nearly ninety percent of blacks lived in the South in 1910. The social networks necessary to facilitate the successful migration and resettlement of a migrant population were not yet established, and life in the South was precarious. Blacks were at all times subject to the horrors of physical and symbolic racial 
violence, such as lynching, false arrest and convict labor, rape, and displacement, and whites were empowered to perpetuate such acts of extralegal violence with impunity in order to maintain the racial contract of the South in the post-emancipation era. As the epigraphs from the Introduction convey, the impetus of the African American Great Migration was the hope to start anew. This dissertation traces this era of black striving. 


\section{CHAPTER TWO}

\section{Turning the Screw of Interpretation on the Archive}

January 2013 |Chicago, IL: I was sitting in Mr. Schaffer's apartment conducting my survey. He was 86 years old at the time and had lived alone for the last 50 years. His

home was meticulous, yet filled with a lifetime of memories. During the interview, I asked him about his high school education. He got up and hobbled to his bedroom and

brought back a copy of his high school diploma and all of his report cards from the

Lynch Colored Public School. I asked him if he had ever served in the military. He reached over in his drawer and pulled out a picture of him serving in Germany during World War II. This went on and on until I got through my survey. Once I finished he said, "You know once I die, all of this stuff will end up in a dumpster. I don't have any children or living siblings. I hope you will come back and take some of this so you can get the story right."

February 2013 | Cleveland, OH: Mr. Mimes heard that I was 'doing a book' on blacks from Harlan County, so he took the liberty of organizing a lunch with a few other homefolks he knew in the area. I showed up to the restaurant and our table was ready.

Mr. Melvin Duncan was already there, seated and contemplative. We embraced, introduced ourselves, and he handed me a faded green book. It was the yearbook of the class of 1964-the first graduating class to integrate from the 'colored school' to the

'white school'. He told me that I would need to take it with me so I could see how invisible the black students were during that first year. He also asked if there was any way Brown University could digitize the book so he could share it with his classmates.

March 2013 | Aliso Viejo, CA: I showed up to John Steward's home at 3pm to conduct the survey. I was hoping to be no more than 90 minutes because I had a social event to

attend back in Los Angeles that evening. When I walked in, he had five boxes neatly presented in the foyer. We spent the next three hours going through documents relating to his uncle--a coal miner in Benham, --, the formation of the Los Angeles chapter of the

Eastern Kentucky Social Club, and his military, educational, and professional experiences. As time dwindled, we raced through the survey and I got myself together to leave. He looked at me with a bit of confusion and said, "You're going to take the stuff, right...?" 


\section{Introduction}

They warned me that I'd never get the real history the way I was going about it. They said I needed to capture the story. I listened. And I stepped on a wellspring.

These were some of my first encounters with fieldwork. I had decided to return to my roots for my dissertation by studying the intergenerational African American migration in and out of the coal camps of eastern Kentucky. I am not "from" there, but my mother and father and their mothers and fathers all partook in the journey through those mountains. Although my parents left in the 1960s, they still consider Lynch, home. Like many other black Appalachian families from that region, my parents, who resettled in Long Island New York, made the pilgrimage home every Memorial Day weekend to reconnect with their eastern Kentucky roots. As a child, I can remember the thrill of packing up in my father's big burgundy conversion van with at least eight other cousins, aunts and uncles for that thirteen-hour drive up to the mountains. When we got there, Lynch would be so packed with people that it seemed like it took more than an hour to drive up or down one of the town's three little one-way streets. That's because we had to stop and greet each and every person as we rolled down the road; hugs, kisses, laughs, and for me a "you looking just like Nita!". I even remember writing about Memorial Day weekend for my first grade show-and-tell assignment. I mainly wrote about Mr. Charlie, a man who sold penny candy to us kids out of his house as a ploy to talk to us about the importance of saving our change and getting a good education. Having grown up in New York, I was just fascinated to see that anything could cost a penny. 
I stopped going to Lynch by the time I was a teenager. My grandparents had passed away, and I had too many other teenage follies to pursue in New York to take the time to "go home" with my mom and dad. It was not until 2011 after I completed my first year of graduate school that I would return to Lynch. It had been fifteen years. While sitting on my grandparent's porch I realized that Lynch was a third the size it was when I was a child. Mr. Charlie and most of the other elders of the community had passed away. The kids I used to play with had moved out long ago. And the black bears had made themselves comfortable in the community. They'd come off the mountain right at dusk to rummage through the garbage cans for a meal. Although my parent's generation came home during Memorial Day weekend, they had all migrated back in the 1950s and 1960s just like my parents had done before I was born. Lynch, was a ghost town.; and so was Benham, Cumberland and all of the neighboring coal towns in Harlan County. It was there during that visit when I decided to use my sociological imagination to, as Bruno Latour says, "reassemble the social". What happened to the black folks in eastern Kentucky? How could virtually an entire population disappear from a place where they were so vitally engrained in just one generation? I was interested not only in the little known story of the intergenerational black migration through the hills of the region, but also in their shared experience of growing up as black folks in America through the pre and post-Civil Rights era—as "black Appalachians" and beyond.

\section{You Got to Get the Story Right}

I took up researching this group in early 2013. Coming from a background in social demography, I originally approached this research project by conducting life history surveys; starting with a small sample of folks who had resettled in Chicago, and 
soon after branching out to locations across the country. However, I began rethinking my methodological choices very early in the process. As a research instrument, the survey extracted events that the migrants had experienced over the life course and turned them into data points that could be counted, measured and compared using the latest statistical software. "What year were you born?, What year did you graduate? Did you ever integrate? if so, in what grade? How old were you when you first migrated out of Harlan County?, Did anyone accompany you? Where did you decide to move? Where did you move next?...so on went the interview for the better part of an hour. The survey had the chilling ability to sterilize their lived experiences and transform them into a discrete set of ahistorical rational actions. At the time, I didn't have the temerity to go back to my Master's thesis advisor and tell him that I wanted to drop the survey and employ a more humanistic method. But in spite of my own reservations, the interviewees resisted the possibility of being reduced to a data set by insisting that I "get the story right". As time went on it became clear to me that they shared a collective sense of urgency to preserve their history. In their archive - their memories, their nicknames, their performances and rituals - remains a unique and rich history that lies virtually untold. Now at an age where the reality of finitude is ever-present in their consciousness, many of them lay awake at night wondering if the traces that they left will, as Michel Foucault (2002) puts it, "be erased like a face drawn in sand at the edge of the sea".

They would interrupt my survey and lace elaborate stories around almost every other question. In one of my first interviews, I asked the participant to tell me what his first job was when he arrived in Chicago. 
"Now get this...I heard an advertisement on the radio that the transit authority was looking for men with military experience to apply. I put in my application and before you know it, someone from the transit authority showed up at my church. They wanted to know what kind of person I was....if I had a family. I got hired into the first cohort of Black bus drivers for the City...... which was a big deal at the time. We was getting paid $\$ 1.38$ an hour! [pause] I'll never forget that. But I see why they went through all those hoops about my character, cause it sure got tested. Wan't [sic] a day that went by that I didn't get cursed at or called a nigger [by passengers] on my route....by little kids and everything. But by the time I retired, all they [his co-workers] called me was boss. See, [pause] it's not how you start, it's how you finish."

-- Robert Pollenitz, born 1927 in Benham, | Hired as a Chicago Transit Bus Driver in 1951, Retired as an Emergency Truck Driver Supervisor 1998

Although this was his response, in the survey it was converted to "bus driver". The stories were arresting. But I could never capture their full essence in my attempts to write them down. For me, the turning point in my process came about as a culmination of those three encounters described in the exergue that I had with Mr. Schaffer, Mr. Duncan, and Mr. Steward.

By May 2013, I had abandoned the survey and adopted oral history as my primary mode of inquiry. Going into their homes, the interview experience became a sacred space. Oral history methodology centers them as the protagonist of their own history (Hamlin, 2012; Portelli, 1992, 2009); transforming their interviewee status from that of a "research subject" to a "research participant", and a historian of their own subjectivity. It was not the interview alone that created the sacred milieu, but the performance of making history. Paul Gilroy (1993, p. 200) echoes this observation about the performative nature of storytelling in The Black Atlantic, where he writes, "more important than their content is the fact that during the process of performance the dramatic power of narrative as a form is celebrated. The simple content of the stories is dominated by the ritual act of story- 
telling itself. This involves a very particular use of language and a special cultural dynamics." We were all seduced by the allure of the performance, from the intersubjective play of setting the appointment, the installation of my bulky Marantz 600 audio recorder, the pauses and laughs and the staging of one story after the next with "I'll never forget", all the way to the review and signature of the consent forms.

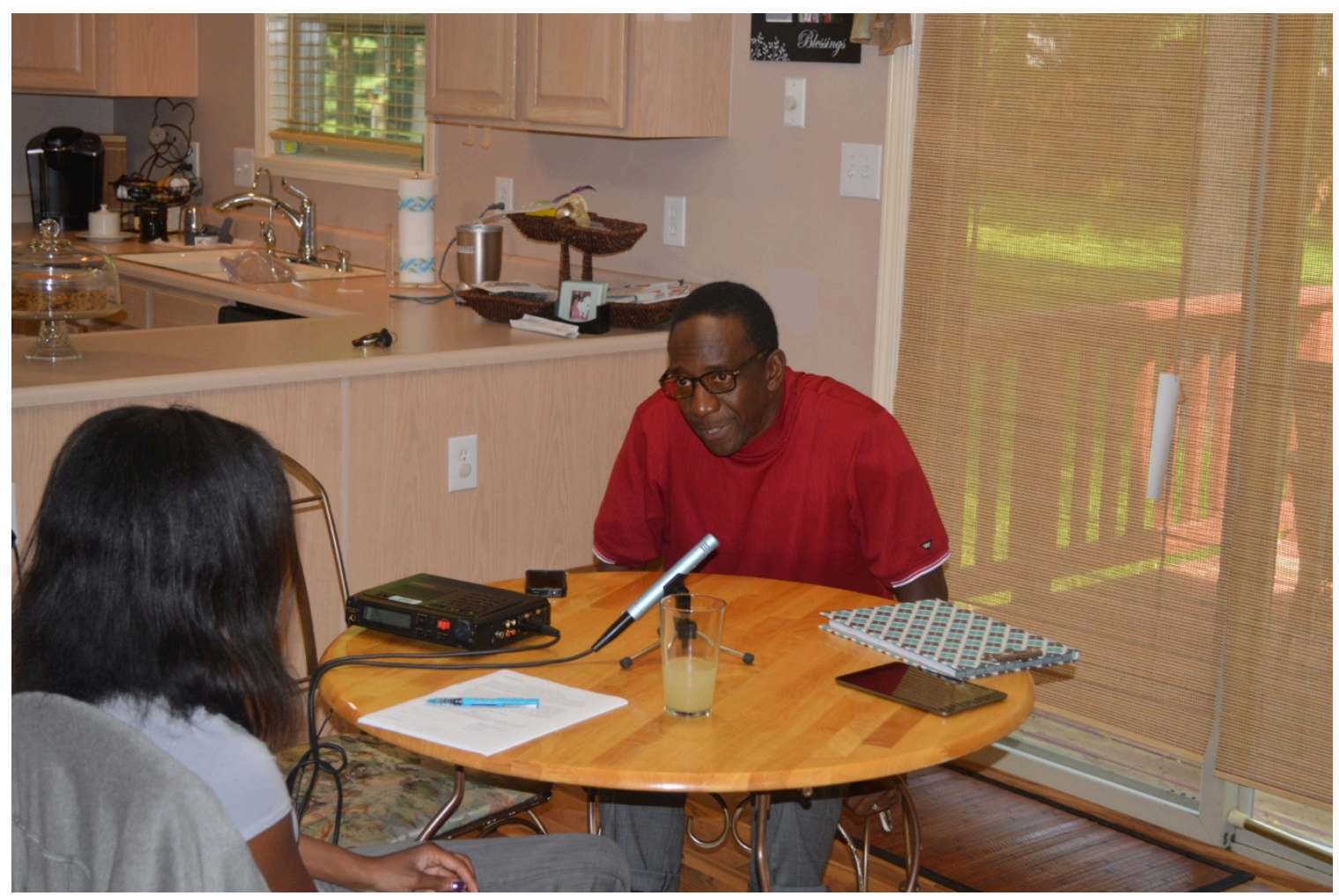

Figure 3. EKAAMP interview \#114 with Dwayne Baskin of Lynch, in his home in Indianapolis, IN

The invitation to play a role in my research through self-narration was the entrée into an unbounded sphere of potentiality. It was at this point in the evolution of the research that we began to take collective responsibility for the project: they, in the giving of themselves, and me, in listening and caring for their stories. The uninhibited unleashing of memory conjured the desire to share more materials - photos, songs, 
recipes, employment statements, military documents, their fathers' black lung claims, unpublished books. They also began to advocate for me by picking up the phone and calling other folks from "home" and asking them to talk to "the girl who is doing the book on us...you know, Nita and Richard's daughter". Because of their participation, I was able to conduct over 150 interviews all over the country in less than two years. In this way, this research project is as much theirs as it is my own.

\section{Methodology}

\section{Sample and Recruitment}

Throughout the empirical chapters of the dissertation, I use primary data from 152 oral history interviews that I conducted between June 2013 and August 2014. The sample includes a cohort of African Americans who migrated out of the coalmining communities of Harlan, and to a much lesser extent, Letcher County, Kentucky, between 1940 and 1980. The sample also includes a subset of "stayers", who are classified as those who never migrated or those who have resettled in the region after migrating out of the Appalachian region of Kentucky.

I employed snowball sample techniques to enroll participants in the project; recognizing that members of a "special population" -- defined as small subgroups of a population that are considered rare and are not commonly visible -- will be aware of other members in that population (Penrod, Preston, Cain, \& Starks, 2003). Given their strong family and institutional ties, participants were most inclined to personally refer family members such as siblings and cousins, as well as members of their high school graduating class. The majority of the participants in this research are retirement-age 
African Americans who were born and raised in eastern Kentucky, and who migrated out of the region shortly after high school graduation. Table X. represents the descriptive statistics of the sample of 152 participants at the time of their oral history interview.

\begin{tabular}{|c|c|c|}
\hline \multicolumn{3}{|c|}{$\begin{array}{l}\text { TABLE 1. DESCRIPTIVE STATISTICS: PARTICIPANT SAMPLE, n=152 } \\
\text { *At time of interview }\end{array}$} \\
\hline Age & & \\
\hline Younger than 65 & $34 \%$ & \\
\hline \multicolumn{3}{|l|}{ Between 65 and 80 years } \\
\hline old & $41 \%$ & \\
\hline Older than 80 years old & $25 \%$ & \\
\hline \multicolumn{3}{|l|}{ Sex } \\
\hline Male & $53 \%$ & \\
\hline Female & $47 \%$ & \\
\hline \multicolumn{3}{|l|}{ Generation } \\
\hline Never Integrated & $51 \%$ & \\
\hline Integrated $9^{\text {th }}-12^{\text {th }}$ grade & $15 \%$ & \\
\hline Integrated $1^{\text {st }}-8^{\text {th }}$ grade & $23 \%$ & \\
\hline Always Integrated & $11 \%$ & \\
\hline \multicolumn{3}{|l|}{ High School Graduate } \\
\hline Yes & $93 \%$ & \\
\hline No & $7 \%$ & \\
\hline \multicolumn{3}{|l|}{ Destination Region } \\
\hline Midwest & $49 \%$ & \\
\hline Northeast & $5 \%$ & \\
\hline Southeast & $16 \%$ & \\
\hline West & $7 \%$ & \\
\hline Stayers & $23 \%$ & \\
\hline \multicolumn{3}{|l|}{ CENTRAL TENDENCIES } \\
\hline $\begin{array}{l}\text { Median } \\
69\end{array}$ & $\begin{array}{c}\text { Minimum } \\
38\end{array}$ & $\begin{array}{c}\text { Maximum } \\
94\end{array}$ \\
\hline
\end{tabular}

Participants' median age at the time of interview was sixty-nine years old, with ages ranging from the thirty-eight to ninety-four years old. Half of the individuals in the sample attended the segregated "colored" schools in eastern Kentucky for their entire K12 education, while the other half experienced school desegregation at some point in their childhood. This delineation is important because, as I argue in Chapter Six, the event of school desegregation was a watershed moment in African American subjectivity. In an 
attempt to trace the paths most travelled throughout this massive out-migration, while staying attentive to less popular "routes to rootlessness" that articulate this black diaspora, I made a real effort to identify participants all over the country and visit them in their homes to conduct their oral history interview. In total this study represents black eastern Kentuckians who currently reside in thirty-one cities, across fourteen states.

I cannot make claims to the representativeness of this study, as I am working with a community en-diaspora. There is no enumerated list of the population during the time in which they lived in their place of origin, and given the issues of dislocation, morbidity, and mortality, I cannot make speculations in this regard. Those matters are, however, beyond the scope or concern of the project. While oral history data, at least in its use in this project, cannot answer questions related to generalizability, it is uniquely suited for the cultural analyses of lived experience, the formation of subjectivities, and, as sociologist Mabel Berezin (2014) argues, the "deeper meanings that structure social action." Also, collected systematically, oral history data has the potential to fill the extant knowledge gaps in the sociological literature on the Great Migration. Demographer Stewart Tolnay (2003) urges that "time is quickly running out on our opportunity to gather information from the participants in the Great Migration. Before this valuable repository of information disappears, researchers should consider the potential of welldesigned approaches to record the life histories of migrants." In spite of sampling limitations, he argues that "such qualitative evidence may not be generalizable to the entire population of southern migrants, but this limitation is counterbalanced by the richness of the first-hand information that can be obtained from the migrants." In addition to the interpretive wealth that this data poses to the topical literature, it is a fecund data 
source with which to produce research that attends to oft ignored questions of subjectivity, to carry out what Hoang and Cobb (2015) calls "protagonist-driven" research.

\section{Oral History Methodology}

The sociological examination of the interiority of everyday life necessitates a certain level of closeness (Fiske, 1992). Oral history methodology provides rich data toward this effort as it centers the interviewee as the protagonist of his or her history through the power of storytelling (Portelli, 2010 ). Stories are audio-textual representations of "discourse, vehicles of ideology, and elements of collective action frames" (Polletta, Chen, Gardner, \& Motes, 2011)that have been used in sociology as a cultural tool for interpreting subjective experience (Somers, 1996),collective identity (Tilly, 2002; Wilkins, 2012), and sense-making (Polletta, 2009).

This mode of inquiry is particularly valuable for studying marginalized populations because they bring to fore "hidden transcripts" (Scott, 1990) that articulate their social world — traces that would otherwise remain undocumented and run the risk of historical erasure. The oral history interview covers seven predetermined topics: (1) childhood memories of growing up in their community of origin, (2) family structure in community of origin, (3) perceptions of race relations, (4) educational experiences, (5) migration, (6) career trajectories, and (7) attachment to place. They are intentionally guided by questions that are broad and open-ended, such as "What was it like growing up as a little boy or girl in Lynch, ?" or "Take us to school. What was that like?" This loosely structured interview-style gives the respondent the opportunity to share memories that are most meaningful to them and to cross-reference memories across topics. Allowing the participant the time to triangulate their memories across time and topic 
lends itself to empirically rich interview data that is primed to be cross-referenced with other historical sources. Interview times ranged from 40 minutes to $3 \frac{1}{2} 2$ hours, subject to factors such as the complexity of the participants life history or the level of intersubjective engagement between researcher and participant.

One obvious limitation of using oral history data for this study is the "messiness" of memory, particularly working with a group of retirement-age individuals. However, following the long tradition of the social thought on collective memory, my central interest is the way in which groups negotiate their collective identity through continual representation of a shared experience (Durkheim, 1915; Eyerman, 2004; Halbwachs \& Coser, 1992; Trouillot, 1995).According to Eyerman (2004), "Collective memory unifies the group through time and over space by providing a narrative frame, a collective story, which locates the individual and his and her biography within it." Thus, the way in which groups presently narrate what happened in the past is of as much sociological import as what "actually" happened (Trouillot, 1995).

Taken collectively, the oral history interviews offered the optimal data for cultural analysis, as it allows for the interpretation of how this generation of African Americans "collectively engage in meaning-making processes" that "structure people's ability to think and to share ideals" (Lamont \& Swidler, 2014). One measure to enhance the durability of the frame of the collective memories is the large sample size. In their Annual Review on the sociology of storytelling, Polletta et. al. (Polletta et al., 2011) argue for the possibility that "stronger narratives might be those that were less coherent rather than more coherent, or that groups might be better off with multiple, even inconsistent, narratives that somehow seemed to hang together". This statement rings true 
with the narratives in this sample. The body of oral history data used for this study captures the dynamic between the particular and the universal of the $20^{\text {th }}$ century African American experience: the collective meta-narrative of the event has taken shape, while allowing for the fluidity and heterogeneity of lived experience.

How do you access, validate, and interpret the "hidden transcripts" of how marginalized communities, namely those rarely hold the pen of history, that often contradict the "official" archival record? To even begin to observe these categories of analysis- "social transformation", "racial self", "African American" and "the Great Migration", required access to data that were responsive to their inherent temporal, spatial, and phenomenological dimensions. The remaining sections of this reflexive essay interrogate the deep-seated issues of data and archive that I had to grapple with in order to produce this study.

Changing methodology was relatively simple. However, the question of what to do about "the stuff" was much more complicated. This group of black folks had collectively constructed their archive - the archive of their diaspora — not only with materials, but also with their memories, rituals, and performances. They had archive fever, and an archive, but no place to store it. I ended up pouring my heart out to Bill Ferris, a mentor who later joined my dissertation committee, about the ethical dilemma I was facing with regards to my research, and the growing burden that was weighing on my heart regarding taking responsibility for "the stuff". In short order, he connected me with 
the staff at the Southern Historical Collection. On June $19^{\text {th }}, 2013$ I drove to the Wilson Library at the University of North Carolina at Chapel Hill to meet with them.

When I first began researching this population, I was immediately confronted with the problem of archives. There was little source material available for me to begin a reliable inquiry into black life in the Appalachia, especially given my lay knowledge into the hidden transcripts of cultural experiences of the group I wanted to research. Railing against the ossified trope of the white Appalachian mountaineer was difficult, grappling with the cumulative erasures rendered by slavery was, and still is, a catastrophe that I am not yet able to describe.

\section{Seeing In-Visible}

The Appalachian region often escapes the collective consciousness of Americana. Even when representations of Appalachia do enter the cultural-historical discourse in academia or in the media, African Americans are rarely inscribed into the social heritage of this region - this erasure can be traced through iconic popular media, such as Academy Award winning films such as Coal Miner's Daughter (1980) and Harlan County USA (1976) to contemporary television series, such as Justified (20102015) and Kentucky Justice (2013-). In spite of its diversity, depictions of Appalachian culture are primarily constructed through the gaze of outsiders who are in search of the iconic white, poor, toothless, backwards mountaineer (Algeo, 2003).

However, as we have read in the Introduction, there were tens of thousands of African Americans who first migrated from the rural South to the coalfields of West Virginia, Tennessee, and Kentucky-if only for one generation-as a first stop 
throughout the Great Migration. Because of this peculiar layover, there are many African Americans across the country who still call Appalachia "home". Yet and still, as Edward Cabbell (1980) squarely put it thirty years ago, "black people in Appalachia are a neglected minority within a neglected minority" and that "their experiences are often so artfully clouded in myth and reality that they remain virtually invisible". Speaking of his frustration with the Appalachian trope and his subsequent invisibility, one participant complained:

"It's always drinking mountain dew. Sisters and brothers sleeping together. Can't read or write. I kind of resented that though because it became a national picture of Appalachia. Only white people. I throw out the rest of the case. When I say that - and I have said to a lot of people that really don't know that I am from Kentucky. And I say the exposés and the things that they portray on Kentucky are all negative, but they never tell you the successful stories and all that. They never mention anything about blacks in Appalachia; the thing with that is they always go to the poor white section of the state..."

--Jack French | Born 1945 in Lynch, | Resides in Cleveland, OH

One of the purposes of EKAAMP is to provide a space for these invisible subjects to inscribe themselves in the institutional archives so they will not be written out of history. Before grappling with the specifics of EKAAMP, I turn to two conceptual frameworks, one theoretical and one historical, to help contextualize this project within the broader discourse on the archive.

\section{Archival Technologies}

In Archive Fever, Jacque Derrida (1996) locates the archival source of power in the acts of what he calls domiciliation and consignation. Domiciliation is the "institutional passage from the private to the public"; the moment when materials become 
the official property of the archive, the moment that they become subject to its power. The archivist is central to this subjugation, as he or she is not only responsible for guarding the contents in the archive but also for maintaining the power to name, interpret and give order to those materials. This authority over consignation, which Derrida refers to as the "gathering together of signs", is the second source of archival power. The cosignatory judgments that the archivist bestows upon materials presuppose how the outsider comes to encounter, consume and understand them as an assemblage.

Because the archive is often encountered as an esoteric labyrinth, the outsider depends on the institutional knowledge of the archivist to guide them to the 'right' sources to find what he or she is searching for. Even when the user is left to consume archival materials with their own set of intentions, they encounter the consignations that the archon has impressed upon the documents - the way they are grouped, the order in which they are stored, and sometimes the user encounters an inscription made on the document by the archivist. Derrida describes the exergue as one such inscription--the para-text placed on the outside of a document that names or describes its contents, 'serving to stock in anticipation and to pre-archive a lexicon' that gives order to a subject. These impressions pre-order our encounter with the archive and intervene with how we come to make sense of the materials therein.

For him, the archive is necessarily a place; one comprised of a constellation of actors who operate in and around the institutional sphere. Although he acknowledges that archives are produced everywhere - from email to lay conversations - the archive as a category of analysis has a place-specific materiality that is constitutive of 'the archive' as we deploy it in academic discourse. This is because of the domiciliation process that 
constitutes what he describes as 'the passage from the private to the public'. In this reading, institutionalization is the key determining factor for what an archive is and what it is not, as it underwrites the conditions under which legitimate knowledge is constructed. In The Power of the Archive and its Limits, Achille Mbembe (Mbembe, 2002) argues that because archival documents go through this institutionalization process, one that invariably necessitates a series of judgments to determine which materials are deemed worthy of storage, he asserts that "the archive is not a piece of data, but a status". Following Derrida's line of reasoning on the point of locality, he explicitly argues that "there cannot therefore be a definition of 'archives' that does not encompass both the building and itself and the documents stored there".

Before the advent of the Internet, the archivist possessed the primary responsibility for domiciliation and consignation, and therefore the possessed the archival power. He or she had the authority to designate what was worthy of being archived, how collections would be represented, and under what terms and conditions the outsider was allowed to access the materials in the archive (if at all). However, Derrida's analysis is limited by the fact that he only situates these questions in a place-specific, hegemonic context when, in fact, everyday people construct archives in many different forms outside of institutions. In her 2011 article, Archive, Ariella Azoulay extends Derrida's meditation by taking up this very matter. Where Derrida concentrated on the nature and function of the archive-the what--Azoulay turns her attention to the fever itself. In this article, she posits two questions "Why an archive?" and "What do we look for in an archive?" Her argument is that in this contemporary moment, the archive is no longer an inaccessible entity that 
exists out there, but has instead been shifted into the hands of the people. Azoulay argues that today archive fever is:

...manifest in the demand for gaining access to that which is kept in the archive, and the demand for partaking in archival practice, through the founding of new sorts of archives - archives that would no longer allow the dominant type of archive...It proposes new models of sharing the documents stored therein, in ways that requires one to think of the public.

This perspective shifts the analytical frame from the distant institutional archive into the interactive civil sphere, in which the everyday individual and the archive are intersubjectively constructed by their engagement with each other. This reading introduces a new set of politics to questions of the archive:

The archive fever responsible for creating other archive models exposes the fact that the documents it holds regard those striving to actualize this right. Thus, instead of regarding the archive as an institution that preserves the past as though its contents do not directly impact us, I propose to see the archive as a shared space, a place that enables one to maintain the past incomplete, or to preserve what Walter Benjamin referred to as the "incompleteness of the past".

If both the institution and the outsider both have archive fever, how does this change how we think about the archivist? According to Derrida, this person has an insatiable drive not only to guard the materials that are already housed in the archive, but also to acquire and extract new materials to add to the institutional collection. However, as Azoulay brings to fore, the archive has already been revolutionized — the authority of the archon has been democratized and extended to the everyday citizen. New modes of archival practices are constantly entering the social sphere and new forms of "domiciles" are widely available, particularly through the Internet.

In thinking of the various existing and potential "domiciles" the archive in the broadest sense, it becomes clear that the archive can be located anywhere that knowledge 
is constituted, including the body, memory, discourse, dance, utterance, and so on. Anthony Bogues meditates deeply on "locating epistemologies" in his 2011 lecture Refiguring Archive: Text, Body, and Memory, where he asks, "What happens when an archive is destroyed? Not referring to the destruction of a physical institution, but the death, dehumanization and erasure of a people. He argues that a "reframing" of the archive - a decentering of "the document as god"--allows the possibility to produce new or alternative narratives of humanity (Bogues, 2012). Further, it is only through a reframing of the archive that we can begin to construct alternative narratives that articulate the full humanity of those whose subjectivity exists outside the margins of Western thought.

In thinking through the implications of relocating epistemologies, Carolyn Hamilton (2002) takes up the point of sound, place and performance when she writes about the complexity of archiving oral histories in post-Apartheid South Africa. In her essay, "Living by Fluidity: Oral Histories, Material Custodies and the Politics of Archiving", Hamilton argues that although, in the post-Aparthied South African context, oral histories were seen as a "means to derive categories of explanation", ones that allowed the black subject to wield agency over the way their history is documented for future interpretation. However the fact that oral histories were to be preserved under the same archival practices and institutions that work under the auspices of the modern Western episteme, the practice usurps agency away from the black actor and re-subjects him to the colonial power of the archive that has been deemed so problematic. She argues that the materiality of narrative be included in the archive, acknowledging the fact that non-Western cultures have all-the-while been producing there own archives but that the 
materials may not be recognized by historians as valid data. She argues that postAparthied South African archives should transform their archival practices to accommodate what she calls the "fluidity" of the archive. This includes narratives, physical objects and spaces as well as performance. She even finds it problematic that oral histories be subject to transcription because it underlies the logic that sources must be written in order to be valid, thusly negating the recognition that the intonation and improvisation of speech are just as important as the literal text. Hamilton does not argue that there is no value in institutional archives, or archival practices as they exist. She is instead arguing that current practices are not capacious enough to "capture the multiple fluidities involved in the production of historical knowledge".

So how does one go about archiving African American life, history and culture? The anarchivic force of the Trans Atlantic slave trade renders this question almost unanswerable. The irretrievable erasures that reverberate, consciously or unconsciously, through every facet of black life are inescapable. These are largely questions of representation and inscription. I want to take up these concepts of institutionalization, consignation, democracy, erasure, and fluidity to consider the African American archive. To illustrate the thorny relationship between African American history and the archive one need only to turn to the fin de siècle New Negro Movement.

\section{The New Negro Movement and the Impulse to Archive in Black}

The New Negro Movement was a fin de siècle $20^{\text {th }}$ century social movement promulgated by members of the black intelligentsia that vehemently promoted selfdetermined (re)representation to counter racist formulations of the ahistorical, subhuman 
Negro. In their recent anthology, Henry Louis Gates, Jr. and Gene Andrew Jarrett assert that "the New Negro was a major discursive cornerstone of racial representation in the late nineteenth and early twentieth centuries" (Gates \& Jarrett, 2007). New Negro philosopher Alain Locke (1925) articulates the problem of the day with the representation of the Negro figure in his essay, The New Negro, where he writes:

...for generations in the mind of America, the Negro has been more of a formula than a human being - a something to be argued about, condemned or defended, to be "kept down', or "in his place", or "helped up", to be worried with or worried over, harassed or patronized, a social bogey or a social burden. The thinking Negro even has been induced to share this same general attitude, to focus his attention on controversial issues, to see himself in the distorted perspective of a social problem. His shadow, so to speak, has been more real to him than his personality.

The issue of representation was central as it was the New Negro mission to re-present the Negro figure as a human being--one with dignity, self-respect, culture, capability and rights--worthy of mutual recognition in the eyes of the other. This formulation was in opposition to the post-reconstruction representation of the "old" Negro as shiftless, abject and child-like. Members of the movement mainly promoted these representations through the proliferation of black literature, art, history and music.

However, some members had an extraordinary case of what Derrida called archive fever, believing that the only way to inscribe the Negro into the social heritage of Americana was through the archive. Derrida (1995) tells us that:

"We are en mal d' archive: in need of archives...it is to burn with passion. It is never to rest, interminably, from searching for the archive right where something in it anarchives itself. It is to have compulsive, repetitive, and nostalgic desire for the archive, an irrepressible desire to return to the origin, a homesickness, a nostalgia for the return to the most archaic place of absolute commencement. 
In line with Derrida's theorization, New Negro members situated their inherent desire to archive as a question of origins. For example, in 1911, John E. Bruce and Arthur Schomburg helped to establish the Negro Society for Historical Research, an organization whose mission was to collect archival materials "to show that the Negro race has a history which antedates that of the proud Anglo-Saxon race" (Holton, 2007).Under the auspices of this organization, Schomburg amassed one of the largest collections of black art, literature, documentation, and photography in order to supply historians with an archive that dispelled the myth of the Negro as only abject or exceptional. Shomburg (1925) writes on his theory of the Negro archive in his essay, "The Negro Digs Up His Past":

The American Negro must remake his past in order to make his future. Though it is orthodox to think of America as the one country where it is unnecessary to have a past, what is a luxury for the nation as a whole becomes a prime social necessity for the Negro. For him, a group tradition must supply compensation for persecution, and pride of race the antidote for prejudice. History must restore what slavery took away, for it is the social damage of slavery that the present generations must repair and offset.

Historian Carter G. Woodson adopted a similar mission of "remaking" through the establishment of the Association for the Study of Negro Life and History (ASNLH) in 1915. Through his work with the ASNLH, Woodson ran a nation-wide campaign to collect historical materials about the American Negro. He campaigned in black communities across the country encouraging African Americans to donate personal materials related to their own family history. He also edited the Journal of Negro History, which he also used to spread the word about his archival collection and to publish historical scholarship using these sources. Reflecting on his efforts Woodson (1925) noted: 
the public began to see that the need of the hour was not to write books from the scant materials available, but to collect and preserve sufficient data of all sorts on the Negro to enable scientifically trained men to produce treatises based upon the whole truth. In this way only, the Association contended, could the Negro escape the awful fate of becoming a negligible factor in the thought of the world.

This New Negro framing was not necessarily about the archive as a place, but instead about the creating possibility of new discursive formations. At the turn of the $20^{\text {th }}$ century, New Negro activists such as Shomburg and Woodson ardently believed that constituting new archives was the most important intervention that could be made to counter the dehumanized formulation of the Negro. In speaking of the possibilities of these new discursive formations Shomburg writes:

Into these fascinating new vistas, with limited horizons lifting in all directions, the mind of the Negro has leapt forward faster than the slow clearings of scholarship will yet safely permit. But there is no doubt that here is a field full of the most intriguing and inspiring possibilities. Already the Negro sees himself against a reclaimed background, in a perspective that will give pride and self-respect ample scope, and make history yield for him the same values that the treasured past of any people affords.

Shomburg and Woodson's collections were both acquired by major institutionsWoodson's by the Library of Congress and Shomburg's by the New York City Library. Although a momentous feat, the institutionalization of organically produced African American collections was rare and complicated at the time because of restrictive “collection strategies". All archives rely on a collection strategy to determine what niche they aspire to dominate in the memory market, to identify gaps in their current collection, and to raise funds from philanthropists and granting institutions to support their mission. Financial donors acted as invisible cultural agents who literally sanctioned what could and could not enter the archive. This is as true now as it was during the time Woodson and Shomburg were collecting, however the difference for them was, as Jacqueline 
Goggin made plain in her historiography of Woodson's archive, "until recently, white libraries and archives generally showed no interest in collecting primary source materials that dealt specifically with black culture". Further, up until the 1950s, African Americans were often restricted from accessing archives due to segregation policies.

Carter G. Woodson's experience with collecting African American source materials on behalf of the ASNLH is exemplar of this point. Supported by small intermittent donations from the usual suspects - the Slater Foundation, Julius Rosenwald, and the Carnegie Institute - the ASNLH was always at the brink of bankruptcy. However, in 1921, the Laura Spelman Rockefeller Foundation appropriated $\$ 25,000$ towards the institution under the condition that Woodson would amend his proposal to exclude two collecting areas: (1) the study of slavery and (2) the free Negro prior to the Civil War. Woodson accepted the funding and placed his collection, comprised of 5,000 manuscripts, with the Library of Congress. What would the archive be had it not been for the foundation's intentional erasure? In dealing with African American materials, collectors found that navigating the institutional sphere of representation was rife with boundaries. Thus most collections never made it through what Pierre Nora (1989) calls "the passage from memory to history".

However, the landscape for black archives has changed dramatically in the last twenty years. There is an increasingly vociferous race towards the black archive, particularly for privately funded university libraries in the U.S. South. The acquisition of source materials related to the African Americans and the African diaspora are a top priority of many of these institution's collection strategies. New collections are usually acquired from bourgeois donors who have both the wherewithal to preserve the family 
papers and access to archival institutions or from auctioneers who specialize in collecting and appraising historical materials. However, in an effort to capture "history from below", some institutions try to seek out source materials from everyday people, Carter G. Woodson-style. This impulse to preserve African American history is echoed at the national level with the announcement of the forthcoming (2016) Smithsonian Museum of African American History and Culture. Recognizing the problem of representation, the latter institution decided to constitute their entire holdings from the ground up $-\mathrm{a}$ first for any Smithsonian museum. For all of these institutions the question remains, how does one go about archiving African American history? The anarchivic force of the Trans Atlantic slave trade renders this question virtually unanswerable. The irretrievable erasures that reverberate, consciously or unconsciously, through every facet of black "history and culture" are inescapable. Coming full circle with a similar set of problems that our New Negros faced exactly one century ago, questions of institutionalization, participation, erasure and representation loom large.

\section{Returning to EKAAMP}

Like the contemporary institutions described above, The Southern Historical Collection shares in this drive to archive in black. Established on January $14^{\text {th }}, 1930$, The Southern Historical Collection was founded with the mission to document the history and culture of the American South. Inaugurated with a $\$ 25,000$ endowment from Sarah Graham Kenan, newly minted director J.G. de Roulhac Hamilton began an aggressive collecting campaign to build "a great library of Southern records". Within twenty years of inception, by the time of Hamilton's retirement, "The Southern" held approximated 2.1 million manuscript items. Today it holds over fifteen million individual items assembled 
in 4,600 collections. The largest university collection on the American South, "The Southern" is renowned as the gold standard for archival and preservation sciences amongst peer institutions. The archive maintains extensive collections related to slavery, the civil war, the civil rights movement, southern communities, and the antebellum south. Their collections on Appalachia include materials related to local community histories, settlement, labor, and culture. It, however, remains virtually silent on the African American experience in the region. That changed when on June $19^{\text {th }}, 2013$ I came to talk to them about "the stuff".

The meeting, as planned, was completely exploratory and void of expectations. With me I brought samples of "the stuff"- - two 1929 report cards from the Wise County Colored School, some old photographs, a 1951 U.S. Steel paycheck, the articles of incorporation for the California Chapter of the Eastern Kentucky Social Club, and an unpublished book assembled by one of the migrants about the history of the Lynch Colored Public School entitled "Wanting to be Remembered". By the end of the meeting we shook hands and agreed to form a partnership. The Southern Historical Collection would provide a home for the materials related to the migrants' experience and I would help collect it. After months of discussion we agreed to the terms of how EKAAMP would function. The project would exist as a standalone collection within the Southern, meaning that all materials acquired in relationship to my research would be encompassed under the umbrella of one master finding aid. Because of our relative ignorance about the black Appalachian experience, we also agreed not to restrict the content of the donations, meaning that they would consider objects and other non-traditional donations. Lastly, they agreed to my only non-negotiable: no consignation. No individual donation (whether 
from a person, a family, or an organization) would ever be mixed with another, meaning that the future user will encounter the archive as it was originally articulated by the participants.

At that moment, my project converged on Derrida's (1995) augur about the "menacing" of the archive:

It goes without saying from now on that wherever one could attempt, and in particular in Freudian psychoanalysis, to rethink the place and the law according to which the archontic becomes instituted, wherever one could interrogate or contest, directly or indirectly, this archontic principle, its authority, its titles, and its genealogy, the right that it commands, the legality or the legitimacy that depends on it, wherever secrets and heterogeneity would seem to menace even the possibility of consignation, this can only have grave consequences for a theory of the archive, as well as for its institutional implementation. A science of the archive must include the theory of this institutionalization, that is to say, at once of the law which begins by inscribing itself there and of the right which authorizes it.

EKAAMP is an exploratory, participatory archive. The donations are an extension of the stories shared in the oral history interviews and only come to the archive if and when the participant chooses to do so. As the project develops, I continue to ask myself who is the archivist? And what are the implications of this menacing of this that Derrida talks about? We (me, the participants, the staff at the Southern, and the financial donors) are all in a stage of discovery at this point, as EKAAMP is still in its infancy. However, the domiciliation of EKAAMP's first collection, "The Rev. Edgar James Moss Collection”, embodies all of these questions. Therefore, I conclude with a reading of this single donation as a view into the interiority of this archive.

\section{The Institutional Passage from the Private to the Public}


Rev. Edgar James Moss was born on June $8^{\text {th }}, 1940$, in house \#44, in Benham, ; a small coal mining community carved into the mountains of Harlan County Kentucky. Son of a coal miner, the tenth of Ina Mae and Green Moss' eleven children, Edgar James still fondly regards Benham as "home". I met him there, up in the mountains, two Memorial Day weekends ago while conducting field research. I had two cameras in hand, one still camera and one fancy handheld digital camera, both borrowed, neither of which I really knew how to use. But it was a now or never type situation because the blacks from Benham, Lynch, and Cumberland - the Tri-City area — only "come home" on Memorial Day weekend. So I figured something was better than nothing. I woke up early that Saturday morning and took photographs of the community - the landscape, the houses, and the ruins - in a haphazard attempt to try to make sense of what it was about that place that engendered such a strong sense of attachment for the African Americans who grew up there so long ago.

There was a basketball tournament that afternoon that brought the whole community out so I thought it'd be a good opportunity to record some mini-interviews with folks to ask why they "come home" to Kentucky, year-in and year out. Things were going well and it seemed like I was getting into a groove. People seemed to like me, and the camera, so I got bold. I approached a group of men sitting on a porch and asked if they would say a few words for the camera for my "mini documentary". Four men obliged and we began filming, however the fifth stood off to the side and began photographing me while I conducted my interview. He later walked over to me and introduced himself as Rev. Dr. Edgar James Moss. He asked if he could do his interview alone because he had a lot to say, and then proceeded to give a six-minute impromptu 
introduction of himself for the camera. That instantiated the first of many exchanges I would have with Rev. Moss.

I learned that he lived in Connecticut and we made plans for me to visit him later that fall for his official oral history interview. I called him late in the summer to confirm our plans, and he informed me that he would also like to share his photo collection with me during the visit. He was certain that he had the most extensive collection of black life in Harlan County, , Memorial Day weekend, and all of the EKSC reunions because he had been taking photos every day, since 1951, when his brother gave him his first camera. I shared this news with my father and another community member and they were both tickled with amusement. As far as they were concerned, Rev. Edgar James Moss had been walking around all these years "with a camera that aint got no film in it". Everyone knew Rev. Moss, and no one disputed that he always had a camera with him. However no one could attest to actually having seen any of his photography. Over the years, he gained the reputation of being the town charlatan.

I arrived at Rev. Moss' home in Connecticut on a Saturday morning in October. His house was meticulous and there was a huge breakfast laid out for me in the kitcheneggs, bacon, sausage, grits, toast, and fresh brewed coffee--however the only photos in sight were framed $8 \times 10$ s of himself decoratively aligned throughout the living room. Although I felt disappointed about the prospect of this mysterious photo collection, I was happy to have the opportunity to spend time with Rev. Moss and to record his oral history interview. I didn't mention the photos all morning and neither did he. 
After a few hours of talking, Rev. Moss excused himself from the kitchen and returned with five green canvas photo albums. Inside were black and white photos, organized in chronological order dating back to the 50's. The image displayed below is a photograph from one of the albums. The young captured glancing back at the camera right at the shutter's close is a classmate of his, named Pearl, standing in the hallway of the Benham Colored School in 1958. We spent the next few hours going through hundreds of his photos. He recalled names, years, places, and stories that went along with all of them. To his naysayer's chagrin, Rev. Moss had documented their lives while they were not looking.

I've returned to Rev. Moss' home many times since our first visit to look at his photo collection and listen to his melodious stories about growing up in Harlan County, . And he was naturally the first person I called when I formed EKAAMP. He exclaimed that he wanted to donate his entire photography collection before I could offer the invitation to participate.

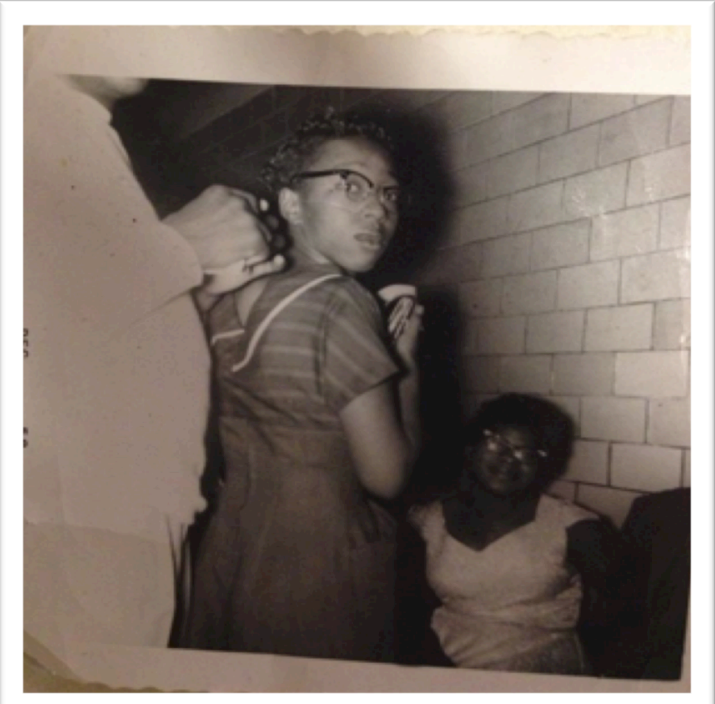

Figure 4. Pearl | The Rev. Edgar James Moss Collection | Dec. 1958 


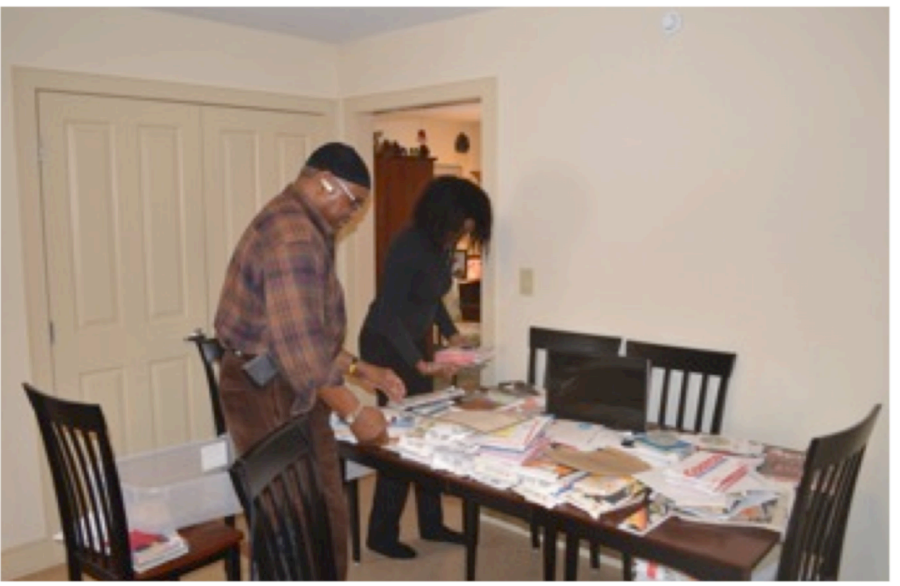

Figure 5. My second visit to Rev. Moss' home to review his photo collection | Dec. 27, 2013

I made arrangements to come and visit him to estimate the size of his collection in order to arrange a transfer between he and the staff at the Southern. When I walked in the house there were piles of photos in everywhere. Rev. Moss had an estimated 60,000 printed photographs, over 5,000 unprinted slides, countless undeveloped negatives, and two terabytes of digital images. His collection was so large that Biff, the archivist at the Southern, had to come to Rev. Moss. 


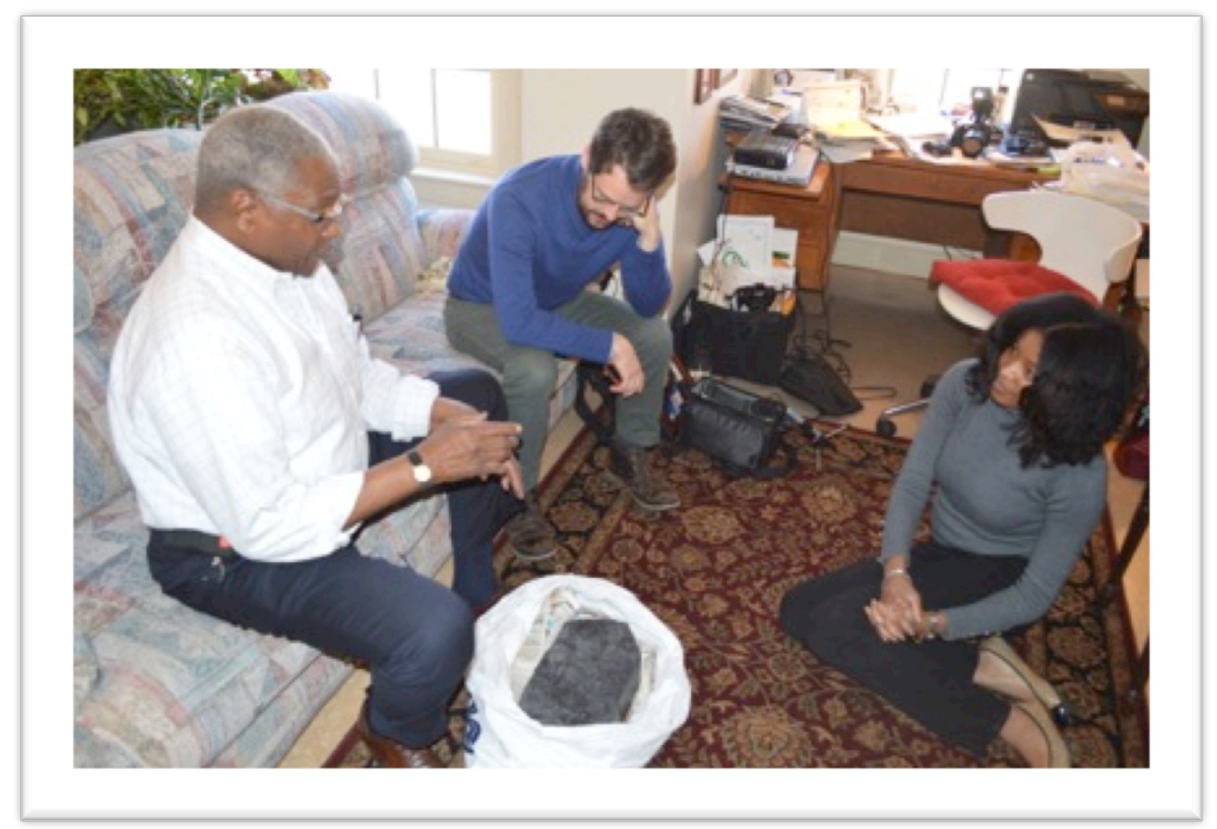

Figure 6. My third trip to Rev. Moss' home along with UNC Chapel Hill archivist Biff Hollingsworth | March 17, 2014

I left that evening to leave Rev. Moss and Biff some time to discuss the terms of his donation privately. I received an email the following morning from Rev. Moss containing a dozen photos of him signing his deed of gift form. For him, this was an inaugural moment. 


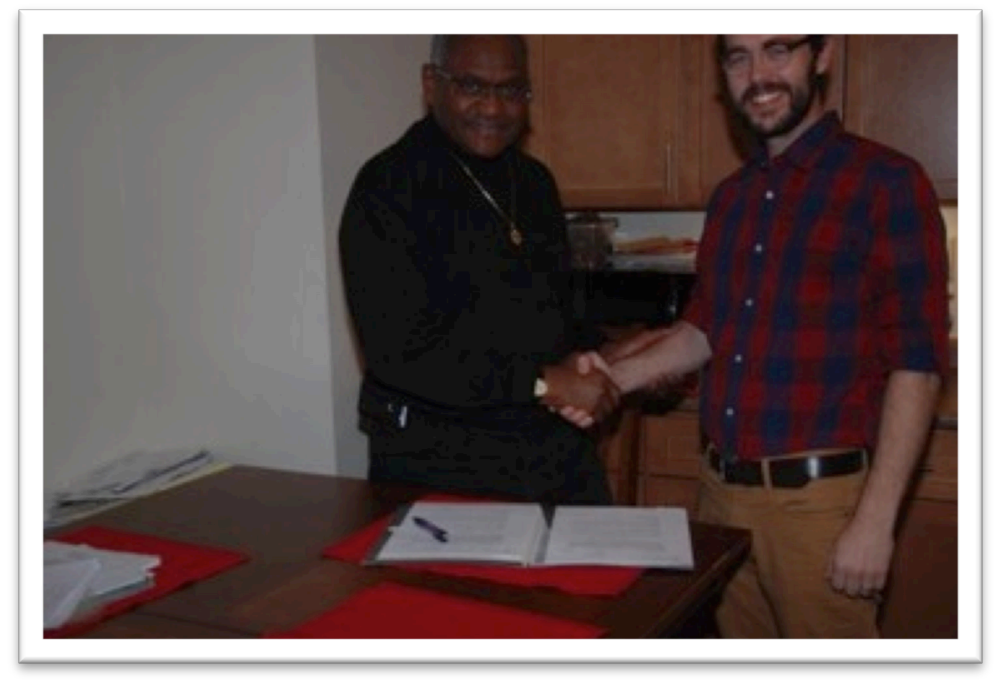

Figure 7. Rev. Moss and Biff Hollingsworth at the deed of gift signing| March 19, 2014

Although he signed his gift agreement early in the spring, Rev. Moss took some time to think about letting go of what represented six decades of his life experiences. Then, on the afternoon of August $9^{\text {th }}, 2014$, I received an email entitled "MY ARCHIVAL PROJECT" that included a brief note and a dozen photographs. In it he shared:

"Today, the first ten (10) boxes of photographs and my "PRIZED LUMP" of Bituminous Coal, mined in Lynch, was shipped by FedEx today! This is a milestone in my life, for which my heart has been made glad. I am looking forward to next shipment of my life's work that will commemorate, pictorially, the life and times of African Americans emanating from the Mountains of Southeastern Kentucky, Harlan County USA and our proud heritage and successes." 


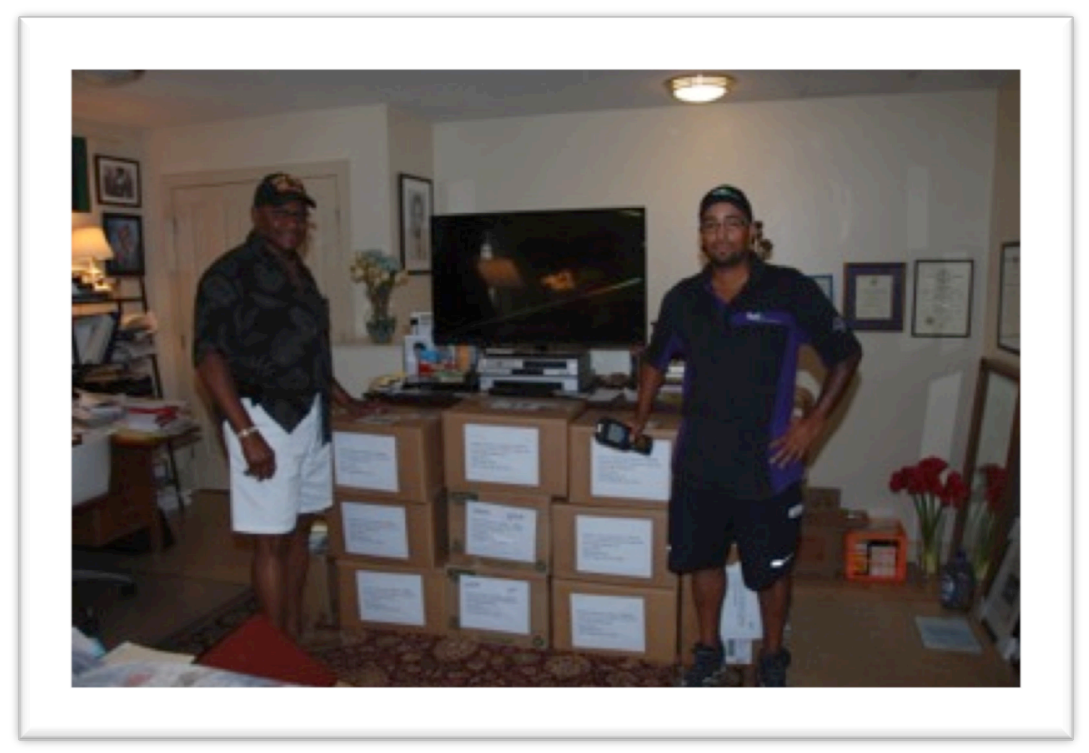

Figure 8. Rev. Moss and the FedEx delivery person initiating the first transfer to EKAAMP| Aug. 9, 2014

\section{Conclusion}

This group of African Americans is engaged in the work of making history. EKAAMP is only possible because of the spirit of collective responsibility, participation and trust through which this project emerged. While their many practices, rituals and invented traditions — such as Memorial Day Weekend and the Eastern Kentucky Social Club — allows black eastern Kentuckians to resurrect home in through collective memory, the EKAAMP archive provides a site for them to make claims on history. Speaking of the difference between memory and history, Pierre Nora (1989) remarks:

Memory and history, far from being synonymous, appear now to be in fundamental opposition. Memory is life, borne by living societies founded in its name. It remains in permanent evolution, open to the dialectic of remembering and forgetting, unconscious of its successive deformations, vulnerable to manipulation and appropriation, susceptible to being long dormant and periodically revived. History, on the other hand, is the reconstruction always problematic and incomplete, of what is no longer. Memory is a perpetually actual phenomenon, a bond tying us to the eternal present; history is a representation of the past. 
In this way, the archival collection will live beyond all of us - the people who shared a role in creating it, the scholars and everyday people who will access it, and you the reader. And while memory belongs to the group of people who construct them, history belongs to the public.

This chapter reflects on this transformation from memory to history. The way in which an assemblage of people, including participants, donors, archivists, and faculty, came together to rearticulate the algorithm of the archive. Resisting the top down collecting strategy that situates the archivist as the authority, the participatory archive centers the knowing subject as the author of his or her own history. It also makes bright the murky political economy of memory. Memory institutions such as archives, museums, heritage centers, and exhibitions are material representations of who we tell ourselves "we" are. As we can see from the case of how African Americans figure into these group narratives — regional, cultural, national, or otherwise — it is apparent that the issue of representation is a slippery slope.

EKAAMP presents a model to tell what Anthony Bogues refers to as "alternative narratives of history". As we have heard from the many voices represented throughout all of the chapters of this dissertation, the subaltern can and does in fact speak. The question remains, "Can you listen?" 


\section{SCENE I:}

\section{The Intergemeratiomal Migratiom of Kemtucky's Coal Camp Blacks}

The grumblings of the African American Great Migration began during the period leading up to World War I, sometime in the early 1900s. Demand for unskilled labor in urban centers in the North and Midwest was urgent at this time of industrial boom- the steel in Pittsburgh needed milling, meat in Chicago needed packing, and railroad tracks all throughout the country needed laying — and labor, during that time, grew scarce. World War I brought the influx of able-bodied migrants from Southern and Eastern Europe to the U.S. nearly to a halt, even after the War had come and gone, the United States rose as the manufacturing powerhouse of the world. At this same time, ninety percent of America's black population resided in the Deep South, and they themselves were primed for a revolution of a different sort.

The decades following the reconstruction era in the Deep South signified a reign of terror for black life. Different from the horrors of chattel slavery, this era marked the configuration of the New South. The white southern gentry were in a scramble to make sense of the new economic and social context in which they found themselves after the defeat of the Confederacy and the embarrassment of federal occupation of the South during Reconstruction. Historically, Southern identity was constructed through the reification of strict ideals of white supremacy, ideals that relied on overt visual, physical, and geographical representations of racial domination and subordination. The postReconstruction era did not herald a period of enlightenment amongst white southerners. In fact their notions regarding the humanity, freedom, and liberty of their newly 
emancipated "fellow Americans" had not evolved. To the contrary, it sparked the fervent drive to rearticulate of the racial order of things that previously structured southern living in the centuries leading up to the Civil War.

The African American Great Migration is a term used to refer to the sixty-year period, between 1910 and 1970, during which an estimated six million black Americans voted with their feet and left the South. It started off as a trickle, but the outpour of black migrants from the South to the North increased with rapid intensity each census year for the next six decades. There is a library of books, memoirs, and speeches describing life in the Deep South during that era that gives context to the racial terror that blacks endured: a tale many times told and worth re-telling. Scholars have illuminated the social and economic forces that conditioned this dramatic outpour of black migrants, its effects on city and community, and on the lives of the many social groups impacted by this macro structural transformation. This dissertation is concerned with its meaning.

What did the Great Migration mean to the six million black folks who traversed out of the bowels of the Deep South into the urban landscapes of the Midwest, the North, and the West? For the early wave of migrants, those who left between 1910 and 1930, how did they manage to get to their destinations? What did it take? And more so, what were they hoping to find? The larger question that preoccupies this project is, what impact did this epoch demographic shift have on African American subjectivity? I use one empirical case to examine these phenomena: the intergenerational black migration through the coal camps of Harlan County, Kentucky. 
Table I. Harlan County, Kentucky Population Change 1900-1970, by RACE

\begin{tabular}{|c|c|c|c|c|c|c|c|c|}
\hline $\begin{array}{c}\text { Yea } \\
\mathbf{r}\end{array}$ & $\begin{array}{c}\text { Total } \\
\text { Population }\end{array}$ & $\begin{array}{l}\text { Total White } \\
\text { Population }\end{array}$ & $\begin{array}{l}\text { Total Black } \\
\text { Population }\end{array}$ & $\begin{array}{l}\text { Percent } \\
\text { White }\end{array}$ & $\begin{array}{c}\text { Percent } \\
\text { Black }\end{array}$ & $\begin{array}{c}\text { White } \\
\text { Change }\end{array}$ & $\begin{array}{c}\text { Black } \\
\text { Change }\end{array}$ & $\begin{array}{c}\text { Total } \\
\text { County } \\
\text { Population } \\
\text { Change }\end{array}$ \\
\hline $\begin{array}{c}190 \\
0\end{array}$ & 9,838 & 9,612 & 226 & $98 \%$ & $2 \%$ & & & \\
\hline $\begin{array}{c}191 \\
0\end{array}$ & 10,566 & 10,002 & 564 & $95 \%$ & $5 \%$ & $4 \%$ & $150 \%$ & $7.40 \%$ \\
\hline $\begin{array}{c}192 \\
0\end{array}$ & 31,545 & 28,644 & 2,901 & $91 \%$ & $9 \%$ & $186 \%$ & $414 \%$ & $198.55 \%$ \\
\hline $\begin{array}{c}193 \\
0\end{array}$ & 64,557 & 58,678 & 5,879 & $91 \%$ & $9 \%$ & $105 \%$ & $103 \%$ & $104.65 \%$ \\
\hline $\begin{array}{c}194 \\
0\end{array}$ & 75,271 & 67,737 & 7,534 & $90 \%$ & $10 \%$ & $15 \%$ & $28 \%$ & $16.60 \%$ \\
\hline $\begin{array}{c}195 \\
0\end{array}$ & 71,751 & 66,298 & 5,453 & $92 \%$ & $8 \%$ & $-2 \%$ & $-28 \%$ & $-4.68 \%$ \\
\hline $\begin{array}{c}196 \\
0\end{array}$ & 51,107 & 47,044 & 4,063 & $92 \%$ & $8 \%$ & $-29 \%$ & $-25 \%$ & $-28.77 \%$ \\
\hline $\begin{array}{c}197 \\
0\end{array}$ & 37,271 & 34,936 & 2,335 & $94 \%$ & $6 \%$ & $-26 \%$ & $-43 \%$ & $-27.07 \%$ \\
\hline
\end{tabular}

As Table 1. shows, the total population Harlan County, Kentucky increased by more than six-fold in just forty years, from 9,988 to 75,271 , between 1910 and 1940 . What is striking about this increase are the racial dimensions of this population change. The white population increased by a little over six hundred percent while the black population rose by more than three thousand percent during the same period, however the black population never exceeded ten percent of the total population. What were the biopolitics of this carefully curated black migration? Who were these people and where did they come from? This influx of migrants was no coincidence, and they poured out just as 
quickly as they came in. The first scene of this dissertation takes up the first wave of the intergenerational migration into Harlan County, covering roughly the period highlighted above.

The first chapter of this scene, The Great Migration Escape, establishes the historical context of the black migration out of the Deep South into Harlan County, Kentucky, specifically into the "Tri-City" area of Benham, Lynch and Cumberland. In this chapter, I reconstruct the migration into the coalfields of Harlan County. How did they get there? Why Kentucky? What were they in search of? I argue that for those early movers, those who left the Deep South during the first wave of the Great Migration (1910-1930) it was not a migration - it was an escape. Because there is no comprehensive publicly available data source on the African American Great Migration, and because the majority of people represented in this generation of migrants have long since passed away, I rely heavily on the post-memory of their children to re-weave the rich tapestry of their journey. I triangulate their memories with data from a fortuitous archival source: the company records that U.S. Steel and International Harvester left behind when they deserted Harlan County. This collection contains a photo archive of over three thousand photographs documenting the construction of the company-owned towns of Benham and Lynch — the source area of this study — as well as detailed correspondence between company executives in the North and their mine superintendents in Kentucky.

The second chapter, Home, introduces the second generation of migrants - the coalminers' daughters and sons - the foci of this research. This chapter examines, what sociologist Isaac Reed terms, the "landscape of meaning" upon which their subjectivity emerged. In this chapter I am concerned with two concepts: "race" and "roots". While 
scene three of the dissertation will take up questions of collective memory and meaning as it relates to home, the chapter in this scene illuminates how this generation of itinerant migrants experienced this place in Appalachia that they hold so dear in their hearts. This chapter also deals with questions of racialization and subjectivity. Drawing on oral history data from 152 oral history interviews that I conducted with this generation of, what William Turner and Ed Cabbell (1980) termed, Black Appalachians, I examine the multifarious, often subtle and elusive, yet nonetheless powerful ways in which the social forces of racism are interpreted and internalized by this generation of black folks as experienced during their childhood. Stated simply, in this chapter I am interested in the emergence of the racial self. 


\section{CHAPTER TWO}

\section{The Great Migration Escape}

No, I really don't know...I never really knew. I think my father came from Alabama somewhere... but really to just sit down and say how it happened - I don't remember any of them actually doing that. But we wondered: "how did you end up here?" I knew it was

because they needed a job, they needed work, but no one has ever really just said what this is..."

-James Perry | Born 1941 in Lynch,

\section{Origin Stories}

"My daddy is from Alabama. (Vyreda Davis Williams)...they came from Alabama to Lynch, Kentucky where they needed coalminers, and that's where a lot of blacks came from-the South...(Ernest Pettygrue) They were from Alabama; somewhere around Utah, Tuscaloosa, Ellisville, down in that area. (Albert Harris) I think my mom and them descended from Alabama to the State of Kentucky...(Samuel Coleman) Mama came from a place called Maytown in the northern part of Alabama and daddy came from the southern part of Alabama, a farming area called Mosses. (Odell Moss) My father was from Tuscaloosa, Alabama...(Virginia Ward) My grandfather was named Lee Halls and he migrated here from Alabama to come here to work in the coalfields. (Sanford Baskin)... and my mother Reila Lee Harris Steward was from Lowndes County, Alabama; Pintilala to be specific. (John Steward) I was born in Alabama and I came to Kentucky when I was eight years old. I was born in 1937. (Betty Powell)...he was from Frisco City, Alabama...(Leslie Lee)...My name is Willie Watts, Jr. and I was born October, $6^{\text {th }}, 1936$ in Docena, Alabama and I came to Benham, Kentucky when I was eight months old. (Willie Watts, Jr.)...I was born on November 25 th 1934 in Docena, Alabama and we moved to Benham, Kentucky in 1936, and we was raised up there until I got married in 1951. (Betty Jewell Watts Rogers)...okay, my father, like I said, was from Alabama, he met my mother here - they dated. She was from Benham and he went to school in Lynch. (Teresa Mimes)...Union Springs, Alabama...Just like many other families, I think that's how we got there - that the patriarch was recruited and actually physically brought up here, and I think sold a house from the company and then sent for the rest of their family. (Dwayne Baskin) My father was from Brookside, Alabama and my mother was from Dolomite, Alabama. (Lena Margaret Jones). My dad was born in Coaling, Alabama, and he came to Lynch looking for a job...(Ron Thomas)...somewhere down in Alabama. Yes, that's where he was born. And he was a coalminer until he retired. (Vera Garner Robinson) She was born in Bessemer, Alabama. And their family moved to Cumberland; they lived on Sanctified Hill. (Janice Brown) Now most of the people in Lynch-I refer to them as old-timers - and most of them came from Alabama but my family came from South Carolina. I don't know of anyone else from South Carolina...(Edwin Gist)...I know all of them were born in some part of Alabama on both sides. (Barbara Haury) I was born in Marion Junction, Alabama on June $1^{\text {st }}$, 1930. We left Alabama in May '36 
and moved to Harlan County, Kentucky, and my daddy worked in the coalmines for US Steel. (Ike Gardner) Well, my dad was from Wylam, Alabama and my mom said she came to Lynch when she was eight years old. So they both came from Alabama; whether they came from the same town in Alabama, I don't know. (Joyce Hall)... she came from Weirton, West Virginia. And because her father was a coalminer she moved back and forth between the coalmining camps between West Virginia and Lynch, Kentucky. So she stayed in different areas in Kentucky and she also stated in different areas in West Virginia. But her parents originally were from Alabama. (Brenda Thornton)... and you know certainly he used to tell me the story over and over again. Now he is from a place called Union Springs, Alabama. His father was a sharecropper in Union Springs but you know the concept of sharecropping-you never break even, you never make any profit, and most times you come up short. (Brian Cash) ...I'm from Jenkins, Kentucky, and I came from Alabama to Kentucky back in 1930. (Mother Ferguson) They were born right outside Birmingham, in a place called Ensley, Alabama. (Arthur Simmons) I come from Queensbury, Alabama in 1936 to Lynch, Kentucky and that's where I resided for a long time. I was schooled there and everything. (Nathaniel Fielder) Alabama. Lafayette, Alabama with some growing up in Talladega, Alabama as well. My father came like other fathers, looking for an opportunity to find wholesome employment; and the coalmines afforded him that opportunity. Migrating from Alabama, you had coal miner opportunities as I understand in the Birmingham area, so there was a natural transition of a lot of residents of Alabama. But he came looking for the opportunity to live a prosperous life, and the coal mining industry afforded him that. (Jerome Ratchford)"

They came from Alabama. They took the train; some got a ticket, most just hoboed. Some of the first-comers even worked for L\&N Railroad Company laying track from Bessemer, Alabama up through the hills of southeastern Kentucky, and after months or years of transitory toil, decided to take root in the burgeoning coal camps in Harlan County, Kentucky. As for the others, they came with Limehouse.

That these men came from Alabama is no coincidence. There were healthy sources of able-bodied laborers in Kentucky and the neighboring Tennessee and Virginia. However, the black men from Alabama possessed something that was invaluable to the coal companies. Experience. The state of Alabama is resource rich in anthracite coal, iron, and ore, and it was the largest producer of coal and fossil fuel in the American South. Blacks were used as free labor in those mines before and after emancipation, as 
enslaved labor in the ante-bellum era and through the convict leasing system after the Civil War through the 1920s (Lewis, 1987). Corporations like United States Steel knew exactly where to target their recruitment efforts in Alabama because they owned the mines there too.

The trek out of Alabama was by no means easy or safe for the black men who decided to leave for a chance at another life. The threat of unspeakable violence, disappearance, or dispossession at the time was real, and was demonstrated through a reign of racial terror in the post-Reconstruction South. There is little primary data on the migration stories into Harlan County. Therefore I made it a point to ask my participants - the sons and daughters of the first wave of migrants'--to recount what their fathers and mothers told them about life in Alabama, their decision to migrate to the mountains of eastern Kentucky of all places, and their journey to Kentucky. Almost all of them knew that their parents descended from Alabama, and many were able to identify a city for one or both of their parents. However, when asked about their parents' lives in Alabama, the most common response was, as William Schaffer, Jr. recalled, "he never would tell.” Upon further pondering, Schaffer's curiosity drifted with my own, “...and the funny thing is my dad never went back to Alabama after he left; he never went back. And he never talked about nothing concerning Alabama." Again and again participants offered the same perplexed recollection when asked if their parents ever shared any stories about life in Alabama: “As far as I know, they didn't talk about their roots too much..."(Arnita Davis-Brown)

That this form of repression was a direct response to the racial traumas they experienced growing up in the Deep South can only be a claim of my own speculation. 
For most, there is no family tree or migration record to tell them where they come from, no family story to pass through the generations about the horrors and hardships of life growing up black in the American South. Instead, their parents left them shards of their shattered lives for their children to piece back together, and make something of it, like a stained glass window. This has been the only way for them to get a glimpse from whence they came.

Hey Nigger!

These traces sometimes resurfaced in moments of vulnerability when parents' pasts haunted their present. Although she described her father as a man of few words, Cynthia Brown Harrington recalled a vivid memory of her father's migration story:

He used to get drunk. And he basically told us the same story when he got drunk about how he hoboed (we call it hitchhike). He said he hoboed from Alabama because he had heard about the jobs in the mines in Kentucky. I think he was in his thirties at that time, I'm not actually sure. But he said he was hoboing and he was walking and these white men saw him one day and they said, "Hey nigger! Where you going?" So he told them that he was going to Kentucky to get a job and he said they continued to taunt him for a while and they said to him, "We heard that niggers can preach". So they said to him, "nigger, preach". And I asked him, I said, "so what did you preach?" He said he only knew one book in the bible. So he preached the Book of Job. So he said he had to do it because he was a little afraid and then he said after he preached they said, "well, we heard niggers like to dance", he said, they said, "nigger, dance". And I said, "did you dance?" He said, "sure, I danced". And you know, once he danced and they taunted him some more they let him go.

-Cynthia Brown-Harrington | Born in 195X in Lynch, | Resides in Greensboro, NC

Those words-"hey nigger!"- - hurling from the mouths of those white men hailed Brown-Harrington's father. The social force of four hundred years of racial domination 
and hegemony, slavery, bondage, and unadjudicated violence claimed his body, and with the wretched understanding that he could do nothing to protect himself from whatever fate his interlocutors chose to visit upon him that day, he obliged them with a timid response. Those were the times that this generation would have liked to forget. Not only did the thought of revisiting those memories pose the potential to unleash volcanic emotions within, no parent wants to pass down a narrative of fear, helplessness and humiliation to their children when simply asked "Who are we?" or, "Where do we come from?"

Some pieced together their migration story through concerted efforts of historical excavation. For instance some participants took on the endeavor to dig up their past later in life by returning to Alabama in search of clues. In an attempt to unearth his roots,

Albert Harris sojourned to Alabama after his father had passed away:

I had the opportunity to meet one of my great aunts in Tuscaloosa, Alabama and I sat at her feet being curious and trying to get some family history... and she just told the story of her especially her brothers and the men in our family, how they just didn't take it. And then she gave me some insight because here in the South too you will see a lot of the [black] Masonic Freemasonry and she told me how instrumental they were in Alabama. That a lot of times the masons and the guys in the death business would put blacks in a casket and transport them across the state. Why? To get them out of the area and keep them from getting apprehended or killed.

--Albert Harris | Born in 1950 in Benham, | Resides in Sunrise, FL

The main purpose of this chapter is to reconstruct the migratory context within which the first wave of blacks migrated into the coalfields of Harlan County, Kentucky. What were the "conditions of exit" under which this generation of black Alabamans migrated? and What was the "migration industry" that orchestrated this peculiar journey 
from Alabama to the rugged mountains of eastern Kentucky? These migratory ontologies are important for establishing, what Hirschman and Reed (2014) call, the "formation story", what they define as historical reconstructions that "explain how social things come to be stable enough to force or be forced" that binds my field of analysis - the African American Great Migration. Once the historical context is laid out, we can then begin the work of interpreting the multifarious subjective meanings and motivations behind this tremendous demographic transformation, for we will have an understanding of the landscape of meaning upon which this specific group of black folks' social world emerged.

\section{The Sending Area}

\section{Post-Reconstruction Alabama}

The post-Reconstruction era was a period of resurrection. Emerging out of the devastation, destruction, and disassemblage of the Civil War, southern states faced the challenge of reconstructing themselves in an image anew. Slavery had been abolished, the Confederacy dismantled, and the modern world no longer suckled at the teat of King Cotton. The period of Reconstruction in the former Confederate states of the South ended with the Compromise of 1877 , just twelve short years after it began. "The Compromise" arose out of the heated contestation over the 1876 Presidential election between Democrat Samuel Tilden and Republican Rutherford B. Hayes. In exchange for Southern Democrat's resigned acceptance of Hayes' inauguration as the nineteenth President of the United States, the unwritten agreement called for Hayes to abandon the federal occupation of the South and to turn a blind eye to matters concerning the welfare of 
African American citizens (Du Bois, 1903). As a result, the white Southern elite were left to re-establish order according to their standards, mores and ideologies. With slavery and the plantation system, this new version of the old order was accomplished through law, custom, and legitimized impunity.

One immediate action following the departure of the Union troops was the adoption of Black Codes, colloquially known as "Jim Crow" laws, into State legislatures. Other ramifications of the Compromise of 1877 was the wholesale disenfranchisement of African Americans from the political sphere, both in terms of voting rights and representation in political office, increased reliance on the convict leasing and sharecropping system as mechanisms to recapture free black labor, and the rise in lynchings and other forms of racial terror as a tool for social control. Without the occupation of the Federal government, governance in the South was left to the oligarchs who formerly occupied the planter class during the times of slavery. With their fortunes nearly destroyed in the aftermath of the Civil War, and those black bodies who were formerly only recognized as property in the white imagination, suddenly began making claims on formerly forbidden categories such as "person", "human", "citizen”, and "American". The majority of white society was willing to do all they could to re-establish the racial order that slavery had once maintained.

\section{Sharecropping}

Sharecropping was a farming tenancy arrangement that allowed black families to contract their labor to landholders in exchange for a percentage of the profits earned from the year's harvest (Seavoy \& Tolnay, 1999). These were contracts of adhesion, meaning 
that the two parties entered into the agreement on asymmetrical terms - where white land owners set the terms of the agreement and maintained control of all of the accounting throughout the contract term while black laborers were only in control of their hope that the contract would be fulfilled when it was time to make good on the agreement. This hope was most often traded in for a heap of disappointment, as it was most common for the black farmers to end up in debt to the landholder at the end of the harvest, creating a system of peonage between debtor and indebted (W. E. B. Du Bois, 1901; William Edward Burghardt Du Bois, 2013; Seavoy \& Tolnay, 1999). Worst yet, it was impossible for blacks to adjudicate these contracts, as the Black Codes in Alabama made it very difficult for a black man to sue a white man in court. In essence, the sharecropping system bound black farmers and their families to plantations much like chattel slavery did.

\section{Convict Labor}

Georgia, Tennessee, and Alabama were the only southern states that used convict labor for mining. The convict leasing system became crucial to Southern states in the post-Reconstruction era when the gentry of the post-bellum South attempted to reconstitute its wealth base. With slave labor abolished, the convict leasing system emerged as the post-bellum rearticulation. As historian Douglas Blackmon (2008) identified, the convict leasing system in the post-reconstruction era South was in a sense "Slavery by Another Name".

Black codes made African Americans subject to arrest for just about anything. Ambiguously worded laws related to loitering and vagrancy were very popular, in addition to laws for petty crimes such as minor theft could subject a black person to 
months or years in jail. Further, the convict leasing system was just as beneficial to the state as it was to the lessees. Lessees, small business owners and major corporations, were leasing bodies, relinquishing them from the operational cost of owning a slave; meaning that they could literally work convict laborers to death, and the state would replace the commoditized body with another convict at no cost.

Georgia abolished the convict leasing system in 1908. Alabama, however, held on this carnivorous system for more than another decade until it was finally abolished in 1920. Nowhere was the convict leasing system more deep-seated than Alabama, as it was crucial to the economic stability of the state treasury. For example, in 1877, the year that the federal government left the South, convict leasing generated $\$ 14,000$ in revenue to the state. By 1890, just thirteen years later, revenues increased almost eight-fold to $\$ 109,000$. Between 1877 and 1900, convict leasing accounted for nearly ten percent of the state's annual budget (Lewis, 1989). It was so profitable, that Tennessee Coal and Iron (a subsidiary of United States Steel Corporation) built the state of Alabama a prison-right on the site of Pratt Mines in the mineral district of Birmingham, Alabama. Alabama held on this practice longer than any other state because of it developed a revenue dependency on the profits that the state made through the system.

Under the convict leasing system, lessees had no incentive to maintain decent work conditions. To the contrary, the mines were decrepit, tuberculosis and typhoid outbreaks were rampant, living quarters were dark and dank, always moist, leaving prisoner's skin always shriveled and peeling and their bodies a welcome host for disease. Convict leasing was too often a death sentence, and any minor infraction while locked up could result in an extension of the sentence for those who survived their initial term. 
According to historian Ronald L. Lewis, "ninety percent of all the crippling accidents and nearly all deaths among Alabama convicts occurred during sentences in the coal mines." Worse yet, the disappearance of black men, women, and children haunted black communities all throughout the South: Were they lynched or killed? Sent to the mines? Did they migrate? The disappearance of black bodies was what sociologist Avery Gordon (2008) calls a "ghostly matter".

\section{Lynching}

There were a recorded 2,805 lynchings in the Deep South between 1880 and 1930, and Alabama claimed nearly ten percent of the black lives lost to lynching during that period (Stewart Emory Tolnay \& Beck, 1995). This five decade period in the postReconstruction era South was marked as the "lynching era". In their comprehensive study on lynching in the Deep South, Tolnay and Beck (1995) found that "targets for violence included politically active or successful African Americans, northern carpetbaggers, and southern scalawags." However, these public and publicized events were carried out to induce a sense of terror throughout the entire black community, as the victims were emblems of what could befall any black person who did not stay "in their place". According to Tolnay and Beck (1995), "lynching in the American South had three entwined functions: first, to maintain social control over the black population through terrorism; second, to suppress or eliminate black competitors for economic, political, or social rewards; and third, to stabilize the white class structure and preserve the privileged status of the white aristocracy." 
Not only were lynchings carried out with impunity, the justifications were random and baseless (Wells-Barnett, 2012, 2014). While rape and murder were by far the most cited "reason" used to justify lynchings, infractions such as "acting suspiciously", "throwing stones", "suing a white man", and "quarreling", were also cited as cause for a murder (Stewart Emory Tolnay \& Beck, 1995). Lynch mobs resorted to this form of extralegal violence not because they were unaware of the court system's propensity to find the accused guilty, or to sentencing them to death; it was the need to make a public spectacle of the sassy Negro. It was an act of terror employed to maintain the racial order of white supremacy and to squelch any thought of protest, mobilization, or justice.

As the accompanying image depicts, lynching was a community event, a celebration, and a ritual to inculcate the racial order across generations. White fathers

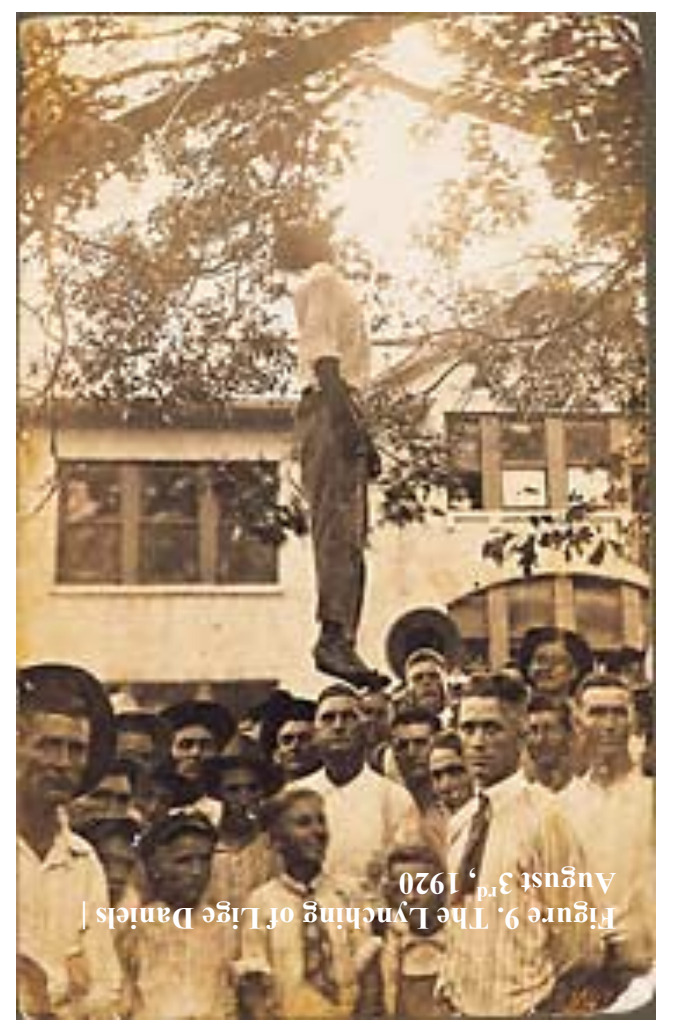
brought their sons, mothers stood to the side and brought their young daughters, and the accomplishment of the day's event often captured in a photograph. This image of the lynching of sixteen year-old Lige Daniels was taken is taken on August $3^{\text {rd }}, 1920$ in Center, Texas. The description accompanying the image tells us that "one thousand men stormed the Center, Texas, jail, battered down the steel doors, wrecked the cell, chose a courthouse yard oak, and lynched Lige Daniels". We can see from the comportment of 
the white men posing in the image that this was a prideful event. So much so that this photograph was reprinted onto a postcard and mailed to family members in other lands. The back of the postcard reads, "This was made in the court yard, in Center Texas, he is a 16- year- old Black boy, He killed Earl's Grandma, She was Florence's mother. Give this to Bud. From Aunt Myrtle."

The widespread desire by whites to document, archive, circulate, and consume visual representations of lynching is telling. Some scholars argue that to promulgate representations of the suffering of others is to reproduce the unjust and unequal power dynamic that the author, in most cases, is working against. That the gaze onto the broken black body in some way allows the white looker to relive, reaffirm, and legitimize the racial order of things, symbolically re-tethering blackness to death. However, in this case I disagree. I argue instead that this one image, and the eighty others like it in the Without Sanctuary photo archive is intended to restore the element of humanity denied Lige Daniel and the thousands of other black people and their families who lived under this "era of lynching", not only in the U.S. South, but all throughout the country, to disallow us from reading this section and justifying the 2,805 recorded episodes of lynching as perhaps "isolated events", "perhaps not that bad" or reducing them to "only 56 occurrences per year". It is also to remind us that textual analyses of lynching, while important, are rarely capacious enough on their own to articulate the fullness of the social force of racial terror. Revisiting that fateful moment in Cynthia Brown-Harrington's father's journey, we can see how he very much understood that when he heard those two words - " Hey nigger!"- was a moment of life or death.

Alabama's Mineral District 
Between the late 1880s through the mid twentieth century, Tennessee Coal, Iron and Railroad Company (TCI) was the second largest coke ${ }^{9}$ producer in the country, and the largest collier in the state of Alabama (Blackmon, 2009; Lewis, 1987). Although the company was established in Tennessee with the goal of gaining a monopoly on the state's extractive industries, it later expanded its purview to Alabama with the purchase of the infamous Pratt Mines in 1895. In 1907, TCI was purchased by United States Steel Corporation (US Steel), which was at the time, the largest corporation in the world in terms of revenues. In addition to Pratt Mines, TCI owned a series of "company towns" on the outskirts of the city of Birmingham. For example, the town of Ensley, Alabama was founded in 1886, just fifteen years after the founding of Birmingham, abutted the Pratt coal seam. Company towns such as Ensley and Corey sprang up in the Birmingham surrounding area, and were built up as planned communities to support the influx of laborers and their families who came to work the mines. During that time, the Birmingham metropolitan area experienced a surge of migration, with workers coming in from Italy, Poland, and surrounding areas in the U.S. South. TCI and companies like it responded by building out company towns, peppered with houses, theaters, schools, and other amenities to attract and retain laborers to the newly growing region. However, migrant workers were not their sole source of labor during this period. TCI was one of the companies that relied heavily on the convict leasing system to meet their labor demands. To that end, the company also built infrastructure, such as prison barracks and company burial grounds, to accommodate the vast body of convicts who matriculated through the coalmines.

\footnotetext{
${ }^{9}$ Coke is a by-product of bituminous coal used as fuel and in the production of iron.
} 
Even with the planned community model, coal companies were notorious for their horrendous labor conditions. In fact, in 1902, the governor of Alabama threatened to ban coal companies from using convict labor due to their labor conditions. In an action approved by Governor Jelks, the State Convict Board announced that "no state convicts will be leased to coal mines of Alabama. About seven hundred convicts are leased to the Tennessee Coal, Iron and Railroad Company and the Sloss-Sheffield Company in Jefferson county." This decision came about at the recommendation of Physician Inspector Bragg who cited that a "change in conditions is necessary to preserve the life and health of the convicts." Unfortunately, this order did not apply to the eight hundred convicts under the purview of the county, which was deemed to be beyond the State's jurisdiction. So singularly vile were the conditions in the mines in Alabama that this order made explicit that this charge would not affect "leases by farmers, lumber mills, and turpentine companies, as their treatment of convicts is satisfactory." ${ }^{10}$ TCI took several measures to assuage state concerns. One way was by building a new prison right next to the Pratt mines (Lewis, 1987), a prison that was regarded the finest in the South. They also responded by experimenting with welfare capitalism. Around 1910, TCI began building model communities with amenities for its labor force, however these amenities were not afforded to the prison population.

The black migration from the mineral district in Alabama to the coalfields of Eastern Kentucky was no coincidence. As we will see, the same company that controlled the extractive industries in Alabama were the very same companies that owned Lynch, Kentucky. All coal companies that set up shop in eastern Kentucky during the World War 
I era were in dire need of a stable labor force to mine the black gold out of the mountains. The industry had not yet mechanized and coal was extracted manually. Therefore, there were two qualities that companies valued above all: a strong back and a special kind of desperation that would keep him returning to the mine, risking his life, and filling his lungs with coal dust, day-in and day-out without complaint.

\section{The Coming of the Coal Industry}

Nestled in the mountainous southeastern corner of the state, Harlan County is located in the Appalachian region of eastern Kentucky; an area sometimes referred to as the Cumberland Plateau. The natural topography consists of rugged, verdant, mountains that lead up to the highest point of elevation in the Commonwealth of Kentucky-some 4,100 feet high — and was populated by Native tribes dating back to a time unrecorded, and by white settlers, colloquially known as the "mountaineers", as early as the 1670 s. This region's history is replete with stories of racial violence towards Native and African peoples, frontiersmanship, slavery, and some of the most notorious family feuds in American history ${ }^{11}$ (Wright, 1996). However the Appalachian region of Kentucky remained sparsely populated in most areas and virtually untouched in others until the coming of the coal mining industry in the late $19^{\text {th }}$ century.

\footnotetext{
${ }^{11}$ Hatfield and McCoy
} 
Classified by the U.S.

Census as the South, we can see that Kentucky is an always already contested place. A border state laden with the historical legacies of the tugof-war between the Union and

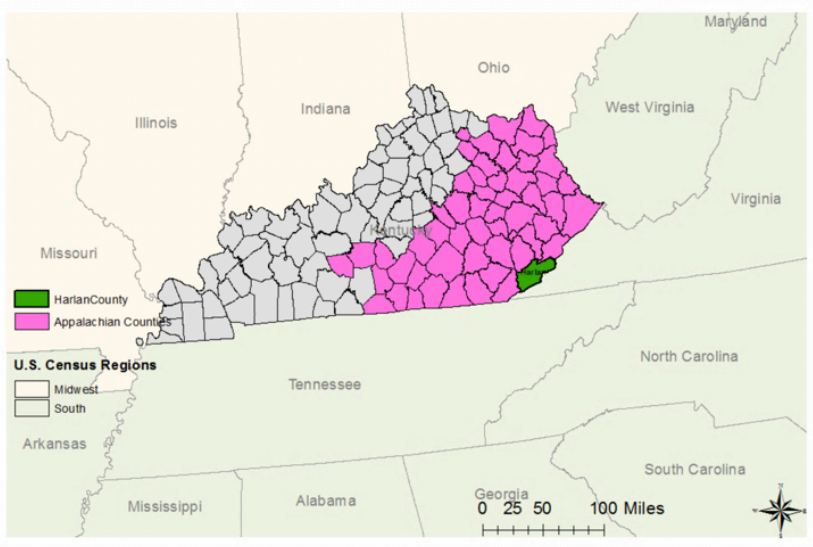
Confederacy, and a third of its

\section{Figure 10. Map of ARC Counties in Kentuc} area consumed by the ever contested "Other" region of Central Appalachia in its eastern parts, Kentucky is best described as a state with multiple personality syndrome. Harlan County too is perfectly situated as a hotspot for turmoil and contestation — the most mineral rich county in the state (coal, timber and moonshine), directly bordering Virginia and a whisper away from Tennessee; there is no doubt that this place earned its name at "Bloody Harlan County".

Speculative investors large and small entered the region with brute force in the $1880 \mathrm{~s}$, convincing the Scotch-Irish mountaineers to sell the mineral rights to their land for pennies on the dollar, and within three decades, they had laid the foundation to begin the cyclopean undertaking of extracting the most valuable resource from the land with little to no responsibility to the environment or the people (Caudill, 1962). The land lay dormant for over three decades, however by 1915, stimulated by the world's war, Harlan County, Kentucky became a niche receiving area for international and domestic unskilled labor migration for the purpose of mining that rich deposit of bituminous coal encrusted in those mountains. Appalachian writer Harry Claudill (1962, p. x) summed it up most 
eloquently in his book Night Comes to the Cumberlands, where he described coal mining as "an extractive industry which takes all away and restores nothing. It mars but never beautifies. It corrupts but never purifies."

The first task that the coal companies had to undertake was to establish suitable living conditions for miners and their families to live. As with any extractive industry, the entire industrial complex was necessarily centered around the site of the intractable natural resource, in this case the mountains. In eastern Kentucky, the coal companies were starting from scratch. Caudill (1962) describes the pre-industrial condition of the region stating that:

"the land was without towns in the accepted meaning of the word so that the incoming crowds of people could find little semblance of such elementary requirements as restaurants and hotels. In most counties the county seat was the only "town" and sometimes its population did not exceed one hundred and fifty persons living in a cluster of log cabins and frame houses about the courthouse and jail."

The race to extract the valuable commodity from the mountains could not be more urgent. Not only was coal the primary source of energy in the United States, it was also primary ingredient in the manufacture of steel. In addition, the world was preparing to go to war.

By the close of the 1920s, the coal mining industry in the region had exploded. For example, in Harlan County alone, coal production increased from less than two thousand tons in 1910, to over three million tons in 1918. Likewise, the number of coal miners rose from a paltry 170 to four thousand workers during that same period (Caudill, 1983, p. 92), and by 1930 , the county boasted a total of 12,741 coalminers - more than any other county in the eastern Kentucky region (U.S. Senate Commission 1930). 
Harlan County emerged as the global epicenter for coal production during the interwar period. In the blink of an eye, company owned coal towns sprang up all throughout the peaks and valleys of the county (Caudill, 1962, 1983; Cressey, 1949; Shifflett, 1995). However, as geologists had discovered back in the 1880 s during the time when northern industrialists had razed the land for its timber, the area in the eastern most corner of the county, where the Kentucky and Virginia state lines meet, laid an enormous deposit of the most high-grade bituminous coal. Much like the rest of the county, this area of a little over eighty thousand acres of land was undeveloped in terms of modern community schemata, sparsely populated, and un-mined.

It was not that no company had taken interest in the land and its resources prior to the coming of the coal mining industry. The aforementioned tract of land was first purchased by an unnamed holding company in 1876. It was common at the time for obscure subsidiaries of conglomerates purchase vast acreage in Appalachia for pennies on the dollar to then lay in wait, speculating a profitable suitor for decades to come. In 1907, trading magnate Warren Delano Jr. purchased this land through a holding company named the Kentenia Corporation, a name inspired by the three bordering states through which the property overlaps—-Kentucky, Tennessee, and Virginia—, conveying ownership of the land and all mineral rights to the entity (Caudill, 1983). It was not at all random that Mr. Delano chose to buy that specific parcel of land, as he had made several journeys to eastern Kentucky with his young grandson Franklin Delano Roosevelt just five years earlier in his capacity as board member for Louisville \& Nashville Railroad $(\mathrm{L} \& N)$. Armed with the internal knowledge of L\&N's plans to expand into the Cumberland Plateau, Warren Delano Jr. was well aware that he stood to make a 
handsome return on his investment. Through the boom Kentenia sold off chunks of land to eager coal and steel corporations, individual investors, and whoever else wanted to try their luck in the mining industry.

This is how central "Appalachia" was produced. It is not an obviously carved out region governed by any particular geographic logic. It was invented in the North-in the offices of the rail, oil, and steel barons in Pittsburgh, New York, and Chicago, and at the New England estates of the American oligarchy. In writing about the sensational drama of the invention of Appalachia, and the formation of the model towns of Benham and Lynch in particular, Harry Caudill (Caudill, 1983, p. 86) writes, "its headquarters were at South Yarmouth, MA, where a relief map of "the Kentenia Country" hung above the paneled walls and Persian carpets of the board room.” No different than the European scramble for Africa occurring simultaneously an ocean away, this Appalachian land grab laid the infrastructure for corporations, government entities, and speculative investors to enter into the region and reap the bounty of the land.

\section{The Tri-City Area: Benham, Lynch, and Cumberland, Kentucky}

Chicago-based agricultural machinery conglomerate International Harvester Company (IHC) was the first to take a stake in developing the area when it founded the city of Benham in 1915 . The company set up a modest mining operation in to supply raw material, namely coal and coke, downstream to its subsidiary, Wisconsin Steel Corporation. Typical to any coal town during that period, Benham offered basic structure necessary to sustain a stable workforce — company houses for miners and their families, a company store, a post office, some form of school, and lodge or two to entertain the men 
when they were not risking their lives in the deep dark abyss of the mines. Although the company town created the basic infrastructure for community formation and social organization, coal towns in the region were notorious for their decrepit living conditions. For example, a 1925 industry study conducted by the U.S. Coal Commission reported that the coal towns in Central Appalachia were the worst in the nation. According to the study "only two percent of the company towns in these states had sewage systems, and in consequence there were serious pollution and health problems in most of them". Typhoid and diphtheria outbreaks spread rampantly in these communities, and miners and their families often living in a perpetual state of precarity, as food supply, access to basic healthcare, a steady wage, and protection from the natural elements were left to the company's whim and fancy. Company's had little incentive to offer anything more than the bare minimum to its employees in terms of living conditions. They intentionally recruited undereducated and unskilled migrant labor, and with little to no attractive alternatives to be found for hundreds of miles, companies were loath to offer anything above the industry standard. However Benham was not one such community. Rather it did not have the chance to become one due to its newfound neighbor: Lynch. 


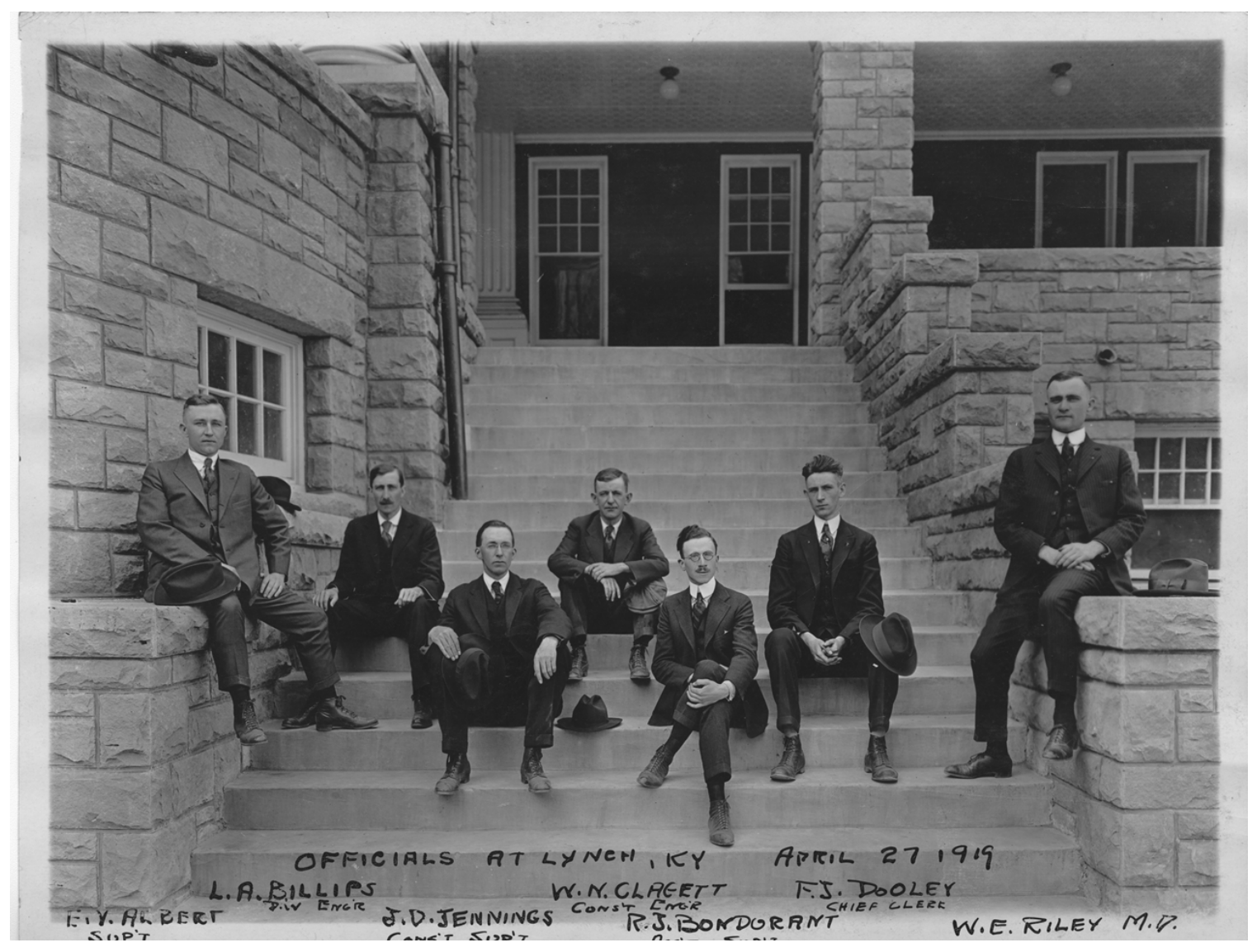

Figure 11. Officials at Lynch, Kentucky | April 27, 1919 (www.appalachianarchive.com)

In the summer of 1917, just two years after International Harvester incorporated the city of Benham, the United States Coal \& Coke Corporation (a subsidiary of United States Steel Corporation) purchased eleven thousand acres of undeveloped land from an absentee holding company out of Pennsylvania called the Wentz Corporation. Geologist L.A. Billups, photographed amongst his fellow northern industrialists in Figure 11, nominated the three and a half mile tract of land as the perfect place for U.S. Steel to stake its claim in eastern Kentucky. According to Billups' assessment of the region, he had "found three veins in the Big Black, all of the coal good and most of it excellent for 
steel making." Better yet, "there was a single tract of the coal of proven title and held by a single owner, the Wentz Corporation of Philadelphia; 14,405 acres contained many hundreds of millions of tons of fuel."

This property was contiguous to the Benham city limits, spanning all the way to the top of Black Mountain. News of their new neighbor was of keen interest to IHC, and rightfully so, as US Steel was one of the largest publicly traded corporations in the world at the time. Their operation stood to interrupt the institutional logics that governed

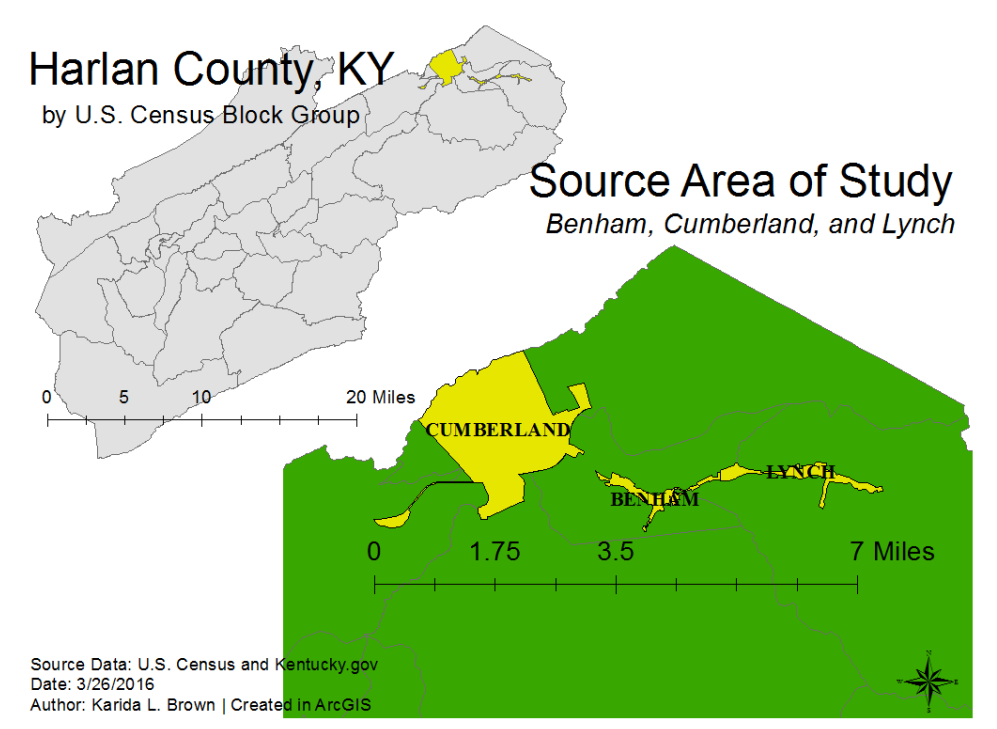

Figure 12. Map of Benham, Cumberland, and Lynch
Benham up to that point, and acknowledging what they stood to loose by continuing with their originally planned business model, IHC immediately adopted a strategy of isomorphism. This thin strip of land comprising Benham and Lynch, two communities that can be covered from end to end within a five-mile walk, would come to be one of the top ten producers of bituminous coal in the United States.

\section{$* * *$}

After he was alerted to the rumor that U.S. Steel planned to set up shop next door by the local Mine Superintendent of Benham, F.B. Dunbar, the President of Wisconsin Steel Corporation, H.F. Perkins, wrote from his Chicago office: 
"...in relation to the purchase or lease by the United States Coal \& Coke Company of the Wentz property. This has an important bearing on us in several ways; first, it will give us good support in handling some labor problems, while on the other hand it will increase the competition in our district. You should watch carefully to see whether they do their preliminary work on an eight-hour day and find out if they are planning to operate on that basis, as their action will probably have a very strong effect on what we must do. I think from what we hear, they are going to develop a very modern and thoroughly equipped plan with fine housing conditions, and we will lose our supremacy in that regard. It will be necessary for us to watch them closely and keep our conditions as far as possible in hand so that we will not be losing our men to them on account of their offering greater attractions to the families of working men. You are quite right in your steps to co-operate with them in giving them such help as they need along reasonable lines."

-- August 6, 191\%. Letter entitled "Labor Matters" from H.F. Perkins (President of Wisconsin Steel) to F.B. Dunbar, Superintendent of Benham Kentucky.

The news was received as a gift and a curse. Yes, U.S. Steel introduced an element of fierce competition that stood to upset IHC's ability to maintain a stable workforce. This was a real concern given that mining process had not yet mechanized, therefore companies relied exclusively on a large labor force to dig and load coal by hand. A byproduct in the production of steel, demand for coal was insatiable throughout the interwar period, and collieries operated three shifts to cover a 24-hour production cycle. In this way, the labor supply was always a prime concern for every company. If U.S. Steel's coal town offered superior wages and living conditions to what IHC offered its employees in Benham, there was a real threat of business disruption. However, from management's perspective, the competition did stand to benefit IHC in terms of coercing their workers to accept their lot in life. If the two company's could somehow view each other as friendly competitors by sharing information and agreeing to adhere to predetermined parameters around labor matters, such as length of workday, wages, and benefits, they might have a chance at thwarting the one social movement that menaced all 
large corporations during the Progressive era: unionization. The stakes were high for U.S. Steel in particular in that regard.

\section{Welfare Capitalism as a Response to the Threat of Unionization}

The question of labor relations loomed large in the minds of the industrial oligarch during this period. The first two decades of the 1900s brought the Populist Era to its head, and elite industrial barons were under national scrutiny for their business practices around monopoly, and issues of labor conditions and worker rights. The companies involved in the coal mining industry, which included almost every major steel and railroad company in the country, was under particular scrutiny because of the infamous Ludlow massacre of 1914 in Colorado (Gitelman, 1988). At Ludlow, miners faced the risk of explosions, mine collapses, suffocation, and a host of other deadly exposures on a day-to day basis. However, it was the work conditions that lead to the massive fall out between the striking miners and their companies. Coal operators subjected workers to seven-day workweeks, no recourse for on-the-job injury or death, filthy work environments, uncapped work hours, and unsustainable wages. Also, like most coal companies, they owned the communities and homes in which the miners lived, creating a paradigm of total control, surveillance and coercion, where miners were forced to circulate their meager earnings right back to the company through the company store, rent, and other usury fees that were forced upon them.

In 1913, the United Mine Workers of America (UMWA) began to organize the miners throughout the southern region of Colorado in an attempt to unionize the miners and make labor demands on their behalf. Employers in this area met their effort with vehement hostility and swift action to thwart any and all efforts to do so by means of 
intimidation, harassment, employment termination, and physical violence. However the UMWA steadily gained momentum in the region amongst the miners and launched a seven-point strike by the fall of the year. Ultimately, eight thousand miners participated in the strike, all of who were forced to move out of their homes by the company. The UMWA set up a near-by tent colony to house the striking workers and their families in anticipation of mass-displacement while they fought for their demands. The coal operators responded to the strike by replacing the striking workers and employing hundreds of private guards to essentially declare war on unionization. The strikers rose to the occasion, responding by openly carrying arms through the coal camps and aggressing guards, coal camp managers, and working miners ${ }^{1}$ alike. An estimated two hundred men lost their lives over the course of the strike, which ended in utter tragedy on April $20^{\text {th }}$, 1914, when 24 people, including two women and eleven children, were suffocated while hiding under a tent in the UMWA colony during a riot (Gitelman, 1988). This event received national publicity and a federal investigation launched by President Woodrow Wilson.

Although several companies operating mining operations in Ludlow, U.S. Steel was publicly shamed as the perpetrator of the massacre, and John Rockefeller, Jr. was labeled as a corporate villain in the media. It is an understatement to say that the stakes were high when they decided to set up colliery operations in eastern Kentucky, in 1917, just three years after Ludlow. U.S. Steel's goal was simple and unchanging: to achieve maximum profits for the corporation and its shareholders. However, the industrial field had become much more complicated, making the former approach of naked feudalism untenable. Whereas in the past, throughout the $19^{\text {th }}$ century, capitalist formations 
emerged in their most naked form, with industrialists staking claims in their fields, maintaining full autonomy over the terms and conditions of labor, and settling external disagreements corporation to corporation, the issue of labor was at the height of public opinion at the turn of the $20^{\text {th }}$ century. There were so many new actors who had entered the field of "labor" who had previously been voiceless, such as labor unions, politicians and government officials, shareholders, and of course, the workers. Corporations were fully aware of this new context, and recognized that they needed a new strategy to control the situation in their favor.

The question of the day for the early $20^{\text {th }}$ century corporation was how to maintain control over the production of labor in this era of progressivism. Unionization was perceived as the greatest threat to profits, therefore priority was placed on developing strategies to counter these efforts. The change would not be to the content of labor arrangements, but the form. Thus came the rise of paternalistic capitalism.

In an attempt to create docile bodies, U.S. Steel Corporation designed its new city of Lynch as a "model town" (Caudill, 1983; Green, 2012; Lewis, 1987; Shifflett, 1995). Beyond creating a bare-bones community to merely maintain a stable workforce, to the model town was an exercise in subject formation. In a letter to President Perkins in Chicago, Benham mine Superintendent wrote "Mr. Billips, their engineer, informs me that they expect to build 1500 houses and expect to complete them at the rate of five per day." With great urgency in his tone Mr. Dunbar underscores that "they are spending large sums of money" and are "sparing no expense" to in the construction of the new coal town, what Harry Caudill (1983) labeled the "Kingdom of Lynch". The paternalistic relationship that animated model company town was adopted to create a false 
consciousness amongst laborers.

\section{False Utopias: The Model Town}

The company's first priority was to attract and retain a stable labor force to extract those rich deposits of coal from the mines, hence the proliferation of the company owned coal town as an organizational form. The company-owned town was by no means a new phenomenon. They first began to appear in the early $19^{\text {th }}$ century in New England with the proliferation of the textile manufacturing industry (Green, 2012). Textile manufacturers were dependent upon the kinetic energy from falling water, and therefore established factories all along the water banks of Massachusetts, New Hampshire, and Rhode Island (Dinius \& Vergara, 2011; Green, 2012).The first company owned mill towns that started to pop up in this region, such as Slatersville, Rhode Island, typically operated one small-scale textile mill and employed fewer than 100 laborers. However, with the technological advancement of industrial machinery, the scale of the mill town exploded. Incorporated in 1821, Lowell, Massachusetts marked the first large-scale planned company owned town with fewer than 2,500 inhabitants, and growing to a population of approximately 33,000 by 1850 (Green 2012). At the time, the company primarily recruited single young women from rural New England communities and first generation European immigrants as factory laborers. Most of these unmarried women lived in boardinghouses, where the company provided them with meals, entertainment and books for enlightenment. The community was replete with churches, retail stores, and entertainment facilities, all owned and operated by the company, creating little incentive for employees to leave Lowell. Instead, their lives and their dollars were insulated within the boundaries of the town. The company also imposed its moral ideals 
on employees by setting codes of conduct in the social sphere of the community, such as requiring steady church attendance and evening curfews. Although the community offered residential, commercial and recreational infrastructures for its employees, this model represents the most rudimentary form of the company owned town in that the company directly controlled the economic, social and civil spheres of society, creating an explicit paternalistic relationship between capital and labor.

Although the purpose of the company town remained the same - to maintain a viable labor force to serve a single capitalist entity in a particular locality - the ideology about the best way to accomplish this goal has evolved over time and varied across industries. The traditional model of the company town characteristically offered the bare bones necessities in terms of infrastructure and resources for employees and their families; monotonous ramshackle housing, a company-owned store, and a school designed to meet only the minimum state requirements. Examples of these communities are the textile towns of the early 1800s, such as Lowell, Massachusetts, and Manchester, New Hampshire, and the coal towns that emerged almost a century later, such as Wheelwright and Neon, Kentucky (Green, 2012; Shifflett, 1995). Companies designed and operated these towns with a means-ends ideology, arguing that the most niggardly investment in the community would generate the highest profit for the company.

A competing institutional logic arose in the late 1800 s with the rise of paternalistic capitalism, which proposed that greater investment in the social welfare of the labor force would have direct effects on employee satisfaction and labor productivity. Industrial communities that emerged under the latter logic are referred to as "model towns", as they put more of an emphasis on the urban planning and aesthetically pleasing 
architectural design. They also offered a wider range of public amenities and resources, such as theaters, hotels, restaurants, and health facilities (Dinius and Vergara 2011; Green 2012). Examples of model towns include the neighboring coal towns of Lynch and Benham, Kentucky - two of the three communities of which this study is based - the railroad town of Pullman, Illinois, and the steel town of Gary, Indiana (Caudill, 1983; Crawford, 1995; Dinius \& Vergara, 2011; Green, 2012; Shifflett, 1995).

Solely predicated on labor and production, the company-owned town is arguably the most ideal environment from which to examine the raw tensions between labor and capital. Few studies on the subject have been able to escape the narrative of the paternalistic relationship between the company and its employees as the extra-legal governance that the companies exerted loomed large over inhabitants' everyday lives.

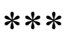

This is the context through which Benham and Lynch emerged. It was the era of progressivism, paternalistic capitalism, unionization, and world war. U.S. Steel was recovering from one of the most publicized corporate scandals of the day, and International Harvester woke up to a behemoth at its bedside. A series of letters between Benham mine superintendent F.B. Dunbar and the Chicago-based President of Wisconsin Steel Corporation (a subsidiary of International Harvester Company) reveal how conscious the company executives were about the climate in which they governed. Yes they were concerned with logistics of running an efficient operation to meet their goals, but they were also concerned with matters of employee moral and mood, the company image, and the sociality of the community that they built. 
U.S. Steel intended on building a company town like no other in Lynch. A new experiment in social engineering, company executives wanted to test the theory of welfare capitalism. If the company created a utopia, a built environment that provided miners and their families everything that they needed and much of what they wanted, at exceptional quality, would workers be disinclined to collectivize through unionization?

F.B. Dunbar was right to take heed of U.S. Steel's intention to "spare no expense" in the construction of Lynch, for it would have great influence on how IHC would govern Benham. In a letter sent on September $4^{\text {th }}, 1917$, just one month after U.S. Steel purchased the land from the Wentz Corporation, Dunbar wrote to President Perkins to apprise him of the grandeur of the coal town that was to come:

"They expect to build a large steel tipple having a capacity of 10,000 tons, which will be located about a half mile east of our property line..." They will also build houses wherever surface conditions will permit, Mr. O'Toole stating that they expect to build about 1500 houses. They expect to build a large department store near the main tipple and have probably two other commissaries farther up the valley. Mr. O'Toole spoke of building a large high school on the plot of ground adjoining our property. Their baseball and amusement park will be at that point also..."

Over the following eight months, U.S. Steel went into a building frenzy. The tipple that Mr. Dunbar references was completed in May of 1919, and was at that time the largest coal tipple in the world. Company houses were erected all throughout the seven coal "camps" comprised in the city of Lynch. Not just the monochromatic ramshackle homes that were common in eastern Kentucky coal camps, the homes in Lynch varied in model, with some built as single-family homes and some as duplexes, and they came in a variety of sizes and colors to offer aesthetic appeal to the community. The main department store U.S. Supply Company, known as "the big store", was also the largest of its kind. Once completed miners and their families could purchase everything from food, 
clothing, furniture, and tailor made suits from that company store. A true model town would not do without a variety of entertainment and amenities. The company built an entertainment facility for its inhabitants, the Victory Theater, that included a restaurant with separate sections for the black and white patrons, a luxurious hotel for executives and visitors, a first rate hospital to serve all U.S. Steel employees and their families. The company even built a baseball stadium and hired their own semi-professional baseball team, the Lynch Greys, to entertain the community with sporting events.

International Harvester had no choice but to respond by expanding its amenities to converge the disparity between the two communities. The school is a good example of their effort. As a border state, the Kentucky statutes adhered to Black Codes for governing race relations at the state level. The state legislature made it illegal for black and white children to be educated in the same schoolhouse. It however did not mandate that county's to offer a high school for black children to receive an education beyond the $8^{\text {th }}$ grade. Therefore IHC had no incentive to offer more than the basic school system required by the state. However, once they learned about U.S. Steel's intention to build a first class school system for its black and white children, IHC had to respond. F.B. Dunbar wrote to President Perkins in 1917 concerning this matter after a conversation with a Lynch executive:

I talked with Mr. O'Toole regarding the school for the colored people and he has instructed his man here to get some data on this matter...They want a graded school for their colored people and a graded school for the Americans and a high school for the Americans.

Benham already had black and white elementary schools and plans to build a white high 
school in their community. However IHC's commitment to providing black education was skeletal. Responding to Benham superintendent's request to build a new school building to accommodate the town's growing black population, President Perkins was hesitant to consider it for fear that the proposed new building that included an indoor toilet would send the wrong message:

"I think he is getting something up that is way beyond what we can do for the colored people; in fact it would be so much better than the white school house that I think it would excited uncomfortable comment..."

If the idea of an indoor toilet summonsed pause with IHC executives, it must have come as an utter shock when six years later, in 1923, U.S. Steel added two state of the art high schools to their community: one for the Americans and one for the "coloreds". This decision created a frenzy with IHC executives and generated dozens of letters back and forth to Benham about what to do about the fact that Lynch offered a colored high school, one with some of the amenities and resources that white schools throughout the region did not even have at the time. Their first thought was to enter an agreement where the black children in Benham could attend the Lynch Colored Public School. However, due to logistical complications, they decided to build a high school for their black population within a year of the opening of the Lynch Colored Public School. We will return to the issue of the deep entanglements between race and education in Chapters Four and Five, but for now I point to this quote to evidence the level of scrutiny that IHC lent to the plans for Lynch and the isomorphic strategies that it adopted to remain competitive.

In the end, the workers benefited from this friendly competition. Nevertheless, neither town was a utopia. Although Benham and Lynch were heralded as model towns, the company's interests were the same as those companies that ran less desirable 
communities in neighboring coal towns - profit. At the time, the coal companies viewed unionization as the biggest threat to achieving optimal profitability. IHC and U.S. Steel attempted to prevent the organizing force of the United Mine Workers of America (UMWA) by creating the veneer or freedom. Some would argue that it worked. As Italian scholar and Harlan County area expert Alessandro Portelli (1990) notes, "Harlan County was the last coal county in the U.S. to accept the union shop clause." However, this was not achieved solely through incentivizing laborers with carrots. Benham and Lynch exercised overtly repressive means to maintain control over their employees. Portelli reminds us that, "even as the "model" company town of Lynch, owned by U.S. Steel, company guards escorted all strangers who came in at the train station to the company office, where they were asked to justify their presence in the camp or leave. The town was surrounded by a wire fence, explicitly intended to keep the organizers out."

This burst of immaculate conception, where city and community were established overnight at the decree of northern corporate executives, instantiated the mass-migration of labor migrants from around the world to pour into Benham and Lynch. Thousands of laborers came in directly from Poland, Hungary, Yugoslavia, Italy, Slovenia, and dozens of other Europeans countries. Fewer came from Kentucky and the neighboring states of Tennessee and Virginia. There was also a rather unusual migrant stream into Harlan County: black folks from Alabama.

...my dad came to Lynch with a guy called Limehouse. You are probably going to hear Limehouse's name a lot interviewing people. But my dad came to Lynch on the back of 
that truck with Limehouse, got a job in the coal mine, and then he went back and got my mama; and they got married...

-William Jackson | Born 1945 in Lynch, | Currently resides in Los Angeles, CA

\section{Better the Devil You Know...}

To understand these migrants' plight, the stock from which they come, and the muster that fueled their strivings, we must get a sense of the origins of this migration. In this section I reconstruct what sociologist Ruben Hernandez-Leon (2013) (2013)calls the "migration industry", a term that he defines as "the ensemble of entrepreneurs, firms and services which, chiefly motivated by financial gain, facilitate international mobility, settlement and adaption, as well as communication and resource transfers of migrants and their families across a border." Migration scholars have rightly identified the role of migrant networks and social capital as central mechanisms for perpetuating mass migration flows. However my primary matter of concern here is the question of how they began. It is difficult to fathom, in this case, that black working-age men living in postReconstruction era Alabama woke up one morning and decided to exit their rural totalitarian environments and migrate to the mountaintops of central Appalachia. How would they have heard about the coalfields there? Better yet, how did they know that Benham, Lynch, or any of the other five hundred coal towns that sprang up in Central Appalachia between 1910 and 1930 would be safe and viable for black life?

These were not light questions for the generation who migrated during the first wave of the African American Great Migration. By 1910, ninety percent of the black population still resided in the U.S. South, and primarily in rural agricultural areas 
(Stewart E. Tolnay, 2003; Wilkerson, 2010; W. J. Wilson, 2012). So essentially, there were no networks, no cousin in Washington D.C. or Chicago to open their home and help you get on your feet, and little information about what lay beyond the oppressive strictures of the Deep South. Stories of the North and freedom surely circulated within the black community, but information about how to initiate such a journey was largely unreliable. Further, blacks were met with great suspicion when attempting to purchase train tickets or access other modes of transportation. As we learned from Cynthia BrownHarrington's father's journey in the previous chapter, all whites were deputized by the mores of Jim Crow to halt black movement with a simple: "Hey nigger! Where you going?”

Corporations carefully orchestrated this labor migration, like many others initiated in the Northern and Midwestern cities at the time. Contra to most classical theories of migration, migrant networks are the proximate cause not the instantiating mechanism of mass migration flows. As economist Michael Piore (1979) previously argued, "thus it is the employers, not the workers, and the jobs, not the incomes, that are strategic", and writing specifically of the first wave of the Great Migration he goes on to argue that "it is U.S. recruitment in Europe, for example, that explains why the black population remained in the South after the Civil War; it was recruitment in the South that explains why large numbers of blacks moved north beginning with World War I." It would be the same industries that historically occluded blacks from the labor economy that would bring them in; thus opening the floodgates for one of the most magnificent demographic changes of the $20^{\text {th }}$ century. Identifying the antecedents that set this particular migrant stream in motion will reveal that this generation of coal miners and their families did not 
end up in Harlan County by coincidence. The remainder of the chapter tackles the following questions: How did they get to eastern Kentucky? And what were they in search of?

\section{Getting There, 1915-1940}

Coalmining companies historically practiced a recruiting strategy to construct its workforce along ethnic and racial lines, called "judicious mixture" (Bailey, 1973; Lewis, 1987). Under this policy, the company targeted a fixed percentage of "native" white, immigrant white, and black workers to live and work in the company-owned towns that were under their purview. The purpose of creating these artificial multi-ethnic communities was to thwart unionization efforts through division. Each group came to the coal town with their own language, culture, motivation, and political conditions of exit, making it less likely for workers and families to effectively organize around similar issues. In the words of Harry Caudill (1962), the early coal towns resembled "turbulent Babels set in a wilderness". In this way, these isolated coal towns peppered throughout the central Appalachian mountainscapes were as cosmopolitan as urban hubs in New York, Chicago, and Philadelphia at the time.

Recruiting was an international effort. Companies partnered with labor agents to recruit laborers to eastern Kentucky: with some agents being sent across the Atlantic to places like Yugoslavia, Hungary, and Italy with a promise of a better life as a coal miner in America, while others travelled a mere four hundred miles south to Alabama to convince the black men in the area of the same. These labor agents often operated under the old "padrone system", an Italian term that translates into "boss" or "manager". 
Popular in the early pre-World War I years of the $20^{\text {th }}$ century, labor historian Gunther Peck (Peck, 1996) describes a padrone as "a labor contractor who imported his countrymen and provided them with jobs in America." Padrones provided a dual service, both to industrial employers, as he was instrumental in helping labor-intensive companies meet their labor demands, and to his fellow country-men, as he was instrumental in helping newcomers adjust to their new life. In most cases, the padrone shared similar lingual, national and cultural backgrounds with his recruits and acted as a cultural resource and advocate for his people. In addition, Peck points out that "the padrone also exploited his intermediary position by charging fees to all immigrant workers for getting and keeping their industrial livelihoods." Although the term was originally coined to describe labor recruitment from Italy to America, U.S. corporations relied heavily on labor agents of all ethnic backgrounds, including Japanese, Greek, Hungarian, and Polish.

The latter system is how the vast majority of blacks got to the Tri-City area of Harlan County, Kentucky. In his analyses of the role of the labor agent in recruiting southern blacks to central Appalachia, historian Ronald Lewis (Lewis, 1987) states, "the labor agent received as much as ten dollars per recruit, and all able bodied men were accepted", in fact, "many agents made arrangements with local jailers to empty the cells of those prisoners who agreed to migrate." This was true for the men who came to work the mines in Behnam and Lynch. However, the agent sent to sneak black men out of Alabama was a white man (Duff, 2004). This modification to the traditional padrone system makes sense given the racial landscape in Alabama at the time. A black man with access to transportation, money, and the authority to dole out promises and dreams to his fellow countrymen would not last long in the Deep South. 
They called him Limehouse. The few that are old enough to bear witness to him describe him as "just a common looking old white man with a big'ole straw hat. I could remember he used to bring sugarcane and I love sugarcane, and daddy would always buy me sugarcane when Limehouse came." (Lorene Clark) However his role in bringing black families from Alabama into Lynch is legendary amongst the black community.

...Well my grandfather used to talk about how he worked out in the fields in Alabama and then they had a man that would come to Alabama because coalmining was booming in Lynch during that time... So this man named--I think it was Limehouse or Lemehouse or something came and got a lot of men--so that's how he got a chance to move up to Lynch and start working in the coal mine. I think my grandfather was about seventeen years old when he started working in the coalmines. Yes, they were out in the fields picking cotton and all of that when they heard about this coalmining. (Shirl BaskinBrack) He said that when he came to Lynch, there was another friend of his and he was a man by the name of Limehouse. They used to bring men up from Alabama and their families to get a job because he knew that they were hiring up here, and that there was also blacks and Hungarians and Germans and people all over this world coming in and getting jobs and he would get up here to get a job. (Lena Margaret Jones) ...but you see every year, every New Year it was a white guy that used to bring people there from Alabama - Limehouse - and he would go to Alabama and anybody who wanted to come back had to pay a fare. And sometimes they didn't have no money but he would bring them anyway and they would come to get a job and they would pay him because he came in every two weeks. (Jessie Willis) ...yeah Limehouse was an ole' funny looking hillbilly. I've seen him...he used to be up there every week in a big truck that had corn and stuff on it, but he had the blacks in the back...corn in the front, blacks in the back. And he used to go up there and you used to see him sitting right up there in front of the big store. That's where he used to be sitting every payday. There were new guys coming out that he had brought up there and he'd be sitting there and he would roll-call and then they had to pay. He had a book and I guess he'd show you [what you owed]. But that's was the deal with Limehouse. (James Stevens)

Of all of my oral history interviews, two participants remembered being brought to Lynch as children by Limehouse: 
“...I was born in Plantersville, Alabama. Then my father and my mother moved to Ensley, Alabama. It got so bad down there [pause] the company U.S. Steel hired a man they called Limehouse. He was bringing all the coal loaders up here to Lynch. And, that's how I got here. And I've been here ever since... And the way I got up here I had to ride on the back end of a truck. Me and another boy. I don't know his name, I don't know where he went to, or what."

--William H. Morrow | Born in 1922 in Plantersville, AL |Resides in Lynch,

"Well at that time at I didn't know anything about Limehouse...my daddy left the farm and went to Birmingham, and then they [the police] tracked him to Birmingham and so he had to leave down there. And he got with Limehouse and they come up here -one of my uncles had got him a job here in the mine. So after year or so, he contacted Limehouse, and Limehouse contacted us in Anniston, Alabama to tell us that my dad had made arrangements to bring us up here. But he didn't come to Anniston to pick us up, to bring us up here. One of his stops for picking up people was in Birmingham on $18^{\text {th }}$ Street. So we went to Birmingham and stayed with my aunt for about a week. And one day he came by - I guess my mother knew him....and we left and came up here...He would pick people up that wanted to get out of Alabama that worked for people on the farm, or owed people money, or was hiding from the law. And he had certain areas that he would go through at certain times and pick up people like that. But the car that we come up here in, he wan't [sic] bringing no men to work, he just had some women - wives of these men that he'd already brought and their kids. There were just some women and kids, there was three women my mother, Miss Baskin, and another lady and her kid and, just some women and some kids though...Well, we got here at night and I seen all these lights I thought I was in a nice place (laughs). But the next day I got up and didn't see nothing but mountains and said oh lord, and I cried for about a week."

--Gene Austin | Born in 1930 in Munford, AL | Resides in Lynch,

$* * *$

While labor agents like Limehouse played a significant role in initiating the black migration into Harlan County they were not the only way that black men discovered opportunity in the Kentucky coalfields. The proliferation of the railways throughout the United States was also a central protagonist in opening new pathways to mobility for 
southern blacks, as they established access to layover stops like eastern Kentucky and beyond. Many first-comers worked for the railroads. Much like the Chinese rail workers of the U.S. Pacific in the $19^{\text {th }}$ century, this labor was by-and-large conscripted. As Betty Parker Duff (2004) pointed out in her unpublished dissertation comparing the company towns in Milenocket, Maine with Benham and Lynch, Kentucky, "the Louisville and Nashville Railroad (L\&N Railroad) brought in thousands of black laborers, many of them convicts, to build the railroads. But unlike the chain gangs of convicts who were forced into labor to build the railroads black tenant farmers came to work the mines willingly." Under the former condition, black labor was leased to rail corporations through convict leasing agreements, peonage arrangements between debtor and company, or through kidnap. One participant illuminates the threat of conscription for black men during that time in Alabama in reflecting upon his memory of his father's migration story:

The only thing he told me was about working on the roads and moving up. He moved up because he didn't want to work on no highway roads and he didn't want nobody whooping him and all that kind of stuff, so he decided that he could not take it...He stayed in Kentucky until 1957 before he went back to Athens, Alabama. And the only reason he went back to Alabama was because his mom died, and he went down there to bury her.

-Willie French | Born 1940 in Lynch, | Currently resides in Lexington,

Although documented in southern history scholarship, traces of the lived experience of this woeful episode of black labor history largely exists in African American music, art, plays, and in family lore. Mississippian soul singer Sam Cooke archives this experience in the lyrics of his 1960 song, Chain Gang, which reached number two on the U.S. Billboard chart that year. In this song Cooke sings: 
All day long they work so hard till the sun is going down Working on the highways and byways and wearing, wearing a frown

You hear they moaning their lives away

Then you hear somebody say

That's the sound of the men, Working on the chain, ga-aaang

That's the sound of the men, Working on the chain, gang

Can't you hear them singing, mmm (Hoh! Ah!)

I'm going home one of these days

I'm going home, see my woman

Whom I love so dear

But meanwhile I gotta work right here...

These are the unsung sorrow songs that these men--the fathers who just wouldn't talk-kept suppressed deep down in their souls so that they and their children might in fact, Dream a World (Hughes, 2000) ${ }^{12}$. Once they arrived in eastern Kentucky, whether by way of laying track, hoboing, or with Limehouse, opportunities for paid labor were plentiful. As the earlier sections describe, coal companies entered Harlan County similar to the scenes in Perry Miller's (2) Errand into the Wilderness. Like the early frontiersman of New England, the companies chartered the land to build towns, cities, governments, and a new culture.

\footnotetext{
12 Referring to Langston Hughes' poem I Dream a World. Its so good we should recite it here: “I dream a world where man No other man will scorn, Where love will bless the earth And peace its paths adorn. I dream a world where all Will know sweet freedom's way, Where greed no longer saps the soul Nor avarice blights our day. A world I dream where black or white, Whatever race you be, Will share the bounties of the earth And every man is free, Where wretchedness will hang its head And joy, like a pearl, Attends the needs of all mankind-- Of such I dream, my world!"
} 


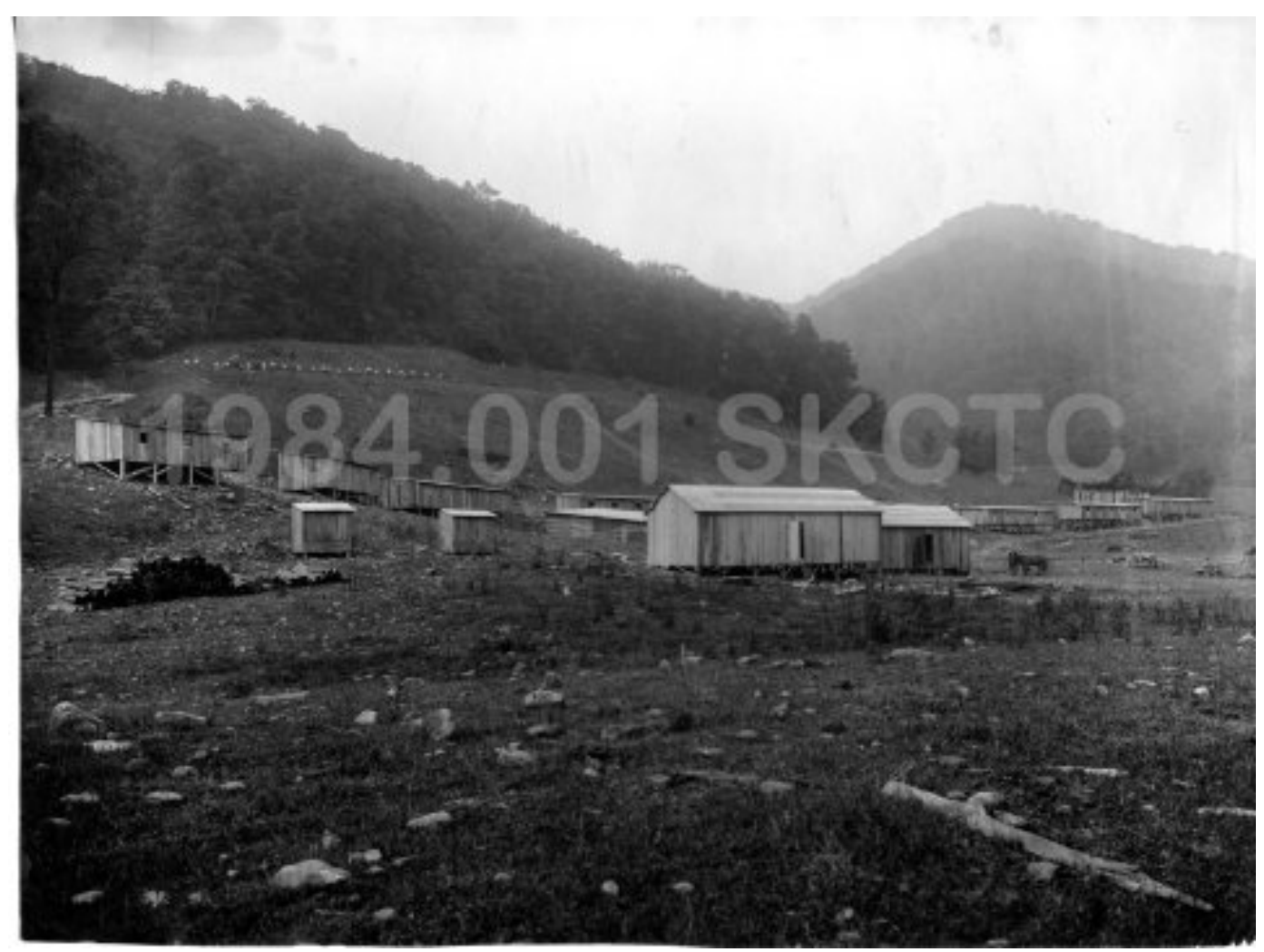

Figure 13. Black white photograph of temporary shanty Lynch, Kentucky. \#0068

There was no shortage of work for first-comers, even before the mining operations in

Lynch began. In an early correspondence from Benham Mine Superintendent to Chicago-

based Wisconsin Steel President H. F. Perkins, Superintendent F.B. Dunbar warned:

"The United States Coal \& Coke people have about 450 men working on construction work and the L\&N have about 50 men in here on construction work"..."Mr. Billups, their engineer, informs me that they expect to build 1500 houses and expect to complete them at the rate of five per day. They hope to have the railroad track and temporary tipple in shape to begin to ship coal by January 1st. Due to the strike they are getting quite a lot of the native labor and are shipping carpenters in from all over the country."..."They expect to begin construction of a large hotel pretty nearly opposite the large rock where the natives used to hold school...

- September 27, 1917. Letter from F.B. Dunbar, Superintendent of Benham Kentucky to H.F. Perkins 
Figure 13. is a photograph of the temporary shanties built in Lynch to house the building crews and rail laborers during the period when the construction of the city was underway. Permanent housing was promised to those who chose to stay in Lynch once the mining operations opened up. Single men were offered company housing in boarding houses, typically sectioned off by ethnicity, and men with families were given priority for single family homes or duplexes. Figure 14. is an aerial image of the building site for the hospital and the sawmill that was set to be built in the center of camp number four in the heart of the city of Lynch. Both images were taken around the

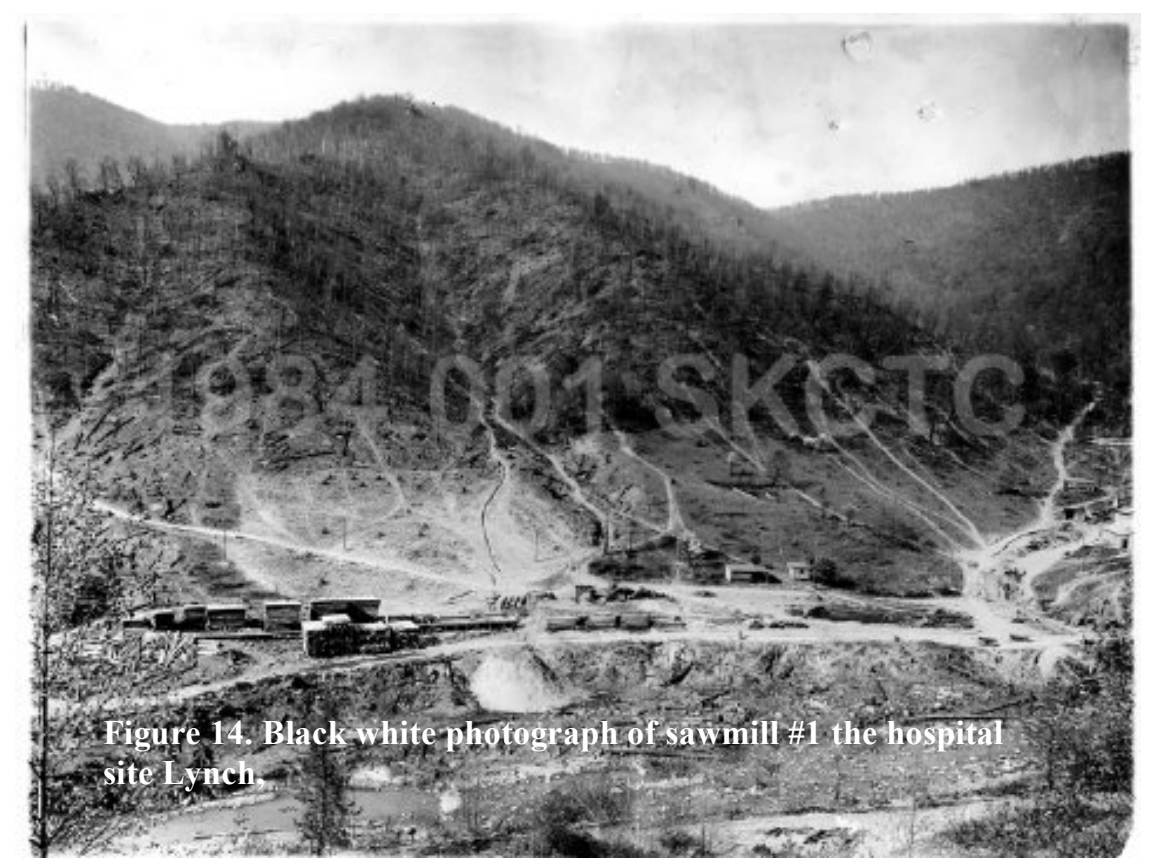
year 1917 and show just how undeveloped the land was at the time that US Steel and International Harvester came in to eastern Kentucky.

\section{Labor, Then Race and Migration}

Once the towns were built, they were ready to get to the business of operating high capacity coal mining operations. Between 1910 and 1940, the Census years capturing the period when mining operations began in both towns through the peak of 
mining productivity in the region, the population in Harlan County increased sevenfold, from a little over ten thousand to well over seventy thousand inhabitants. The black population in Harlan County exploded during that same period, increasing from a recorded 564 black occupants in 1910 to 7,534 in 1940, doubling the black population density from five to a little over ten percent within the short span of three decades. The following two maps are helpful in illustrating the concerted racialized nature of this labor migration. The map depicted in

Figure 15. represents the

number of mine workers by county in eastern Kentucky in 1930 for counties reporting one thousand or more workers. The large yellow dot, the only one in its class, is in Harlan County representing a reported 12,741 coal miners working

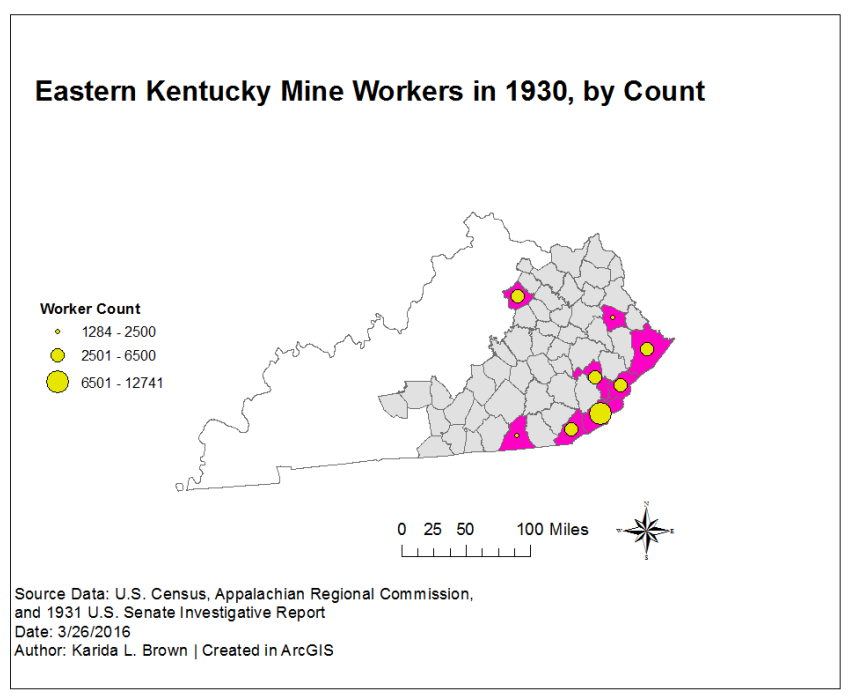

Figure 15. Map of Eastern Kentucky Mine Workers, 1930 throughout the fifty-seven mines in the county in 1930 . The county reporting the second largest worker count reporting 6,091 coalminers-more than half the worker count in Harlan County. The next map is telling with respect to race and migration in and through the Appalachian region of eastern Kentucky. Figure 16. shows the black population density in the state of Kentucky according to the 1940 U.S. Census. The counties outlined in bold represent the fifty-three counties in eastern Kentucky classified by the Appalachian Regional Commission (ARC). Mapping on to popular conceptions of the 
region, this map shows that Appalachia_ or at least in Kentucky — is white. With the exception of the handful of counties bordering the ARC line, counties that are closer to urban centers within the state such as Lexington and Louisville, the majority of eastern Kentucky boasted a black population of less than three percent. However five of the eight counties with substantial mining activity reported above were the same ones to achieve a black population density greater than three percent. It is no surprise that Harlan County, the one with the lion's share of mine workers is also the county that had the greatest population density, at 10 percent, in that corner of the region.

\begin{abstract}
$* * *$
Their choice to migrate to certain counties in eastern Kentucky was determined by labor. They migrated to Harlan County because they were recruited, and because the coalmining industry in eastern Kentucky offered a labor market that was open to black workers. Without the latter condition it would not have mattered whether or not jobs were plentiful, as WHITES ONLY signs were not only reserved for bathrooms.
\end{abstract}

\title{
Striving
}




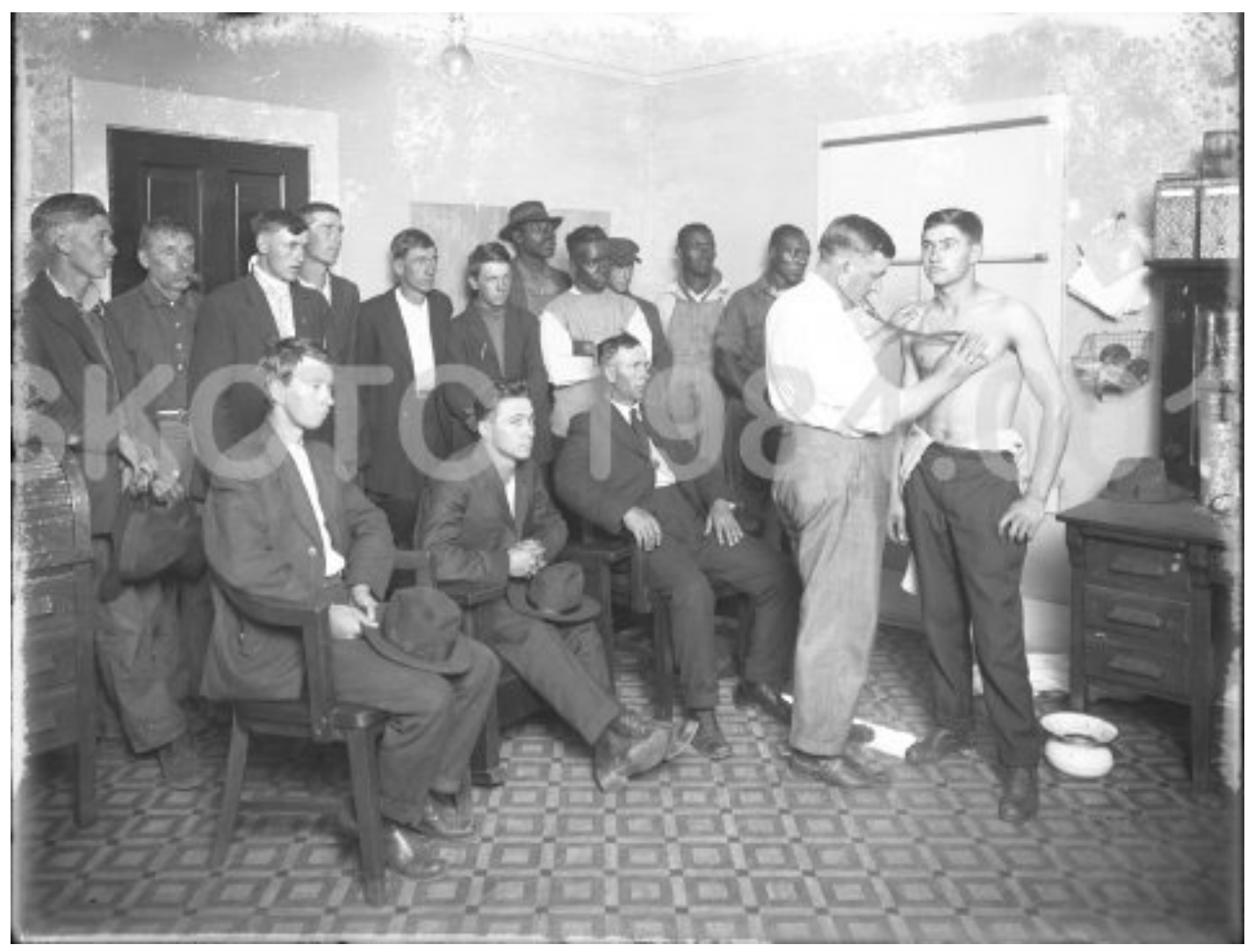

Figure 16. New arrivals getting a medical examination by company physician. Benham, . Circa 1920.

This was the first stop. When men arrived from Ellis Island, by way of Yugoslavia, Italy, Hungary, Poland, or any of the other twenty-eight recorded countries from where the first wave of European immigrants originated, or from the southern plantations, iron, ore, and coal mines, or the cold dank cells of the county jails from where the black men traversed; their first stop on the road to becoming a miner in Benham or Lynch was a medical examination with the company physician. The doctor needed to confirm that their joints, lungs, and backs could endure the work that would eventually break those same parts in the mines. The following images presented in this text offer a rich historical ethnographic site from which to observe how issues of race and racialization were always already there upon arrival. 


\begin{abstract}
Without even having the chance to be fully indoctrinated into the American racial order, the assortment of soon-to-become ${ }^{13}$ white immigrants intuitively know to cluster together, assuming the three available seats in the group examination room, with the rest clustering to the left-side of the frame. In the same way, the black men self segregated off in the right-hand corner. This is not new or unusual for them; through a lifetime-andmore of subjugation through slavery and Jim Crow, they surely "knew their place". Although they were all coming from dire straits—-whether leaving behind a homeland rife with a combination of political, ethnic, religious, and economic strife—and seeking refuge and a better life for themselves and their progeny, we can see in this photograph traces of racial inequality that are produced and reproduced on these men's bodies at this originary moment of becoming.
\end{abstract}

It is sartorial. Although ill-cut and cheaply made, the white men could at least access a tailor or haberdashery and had access to the economic or social capital necessary to purchase or borrow a suit. This group of men came to the job interview dressed to impress, while the black men came in wearing their overalls and jumpsuits—clothing that told the story of their accumulated history: They are farmers. They are laborers. They are slaves. Even if they could afford it, we cannot take-for-granted that there were stores that would sell blacks what may be considered luxury goods, such as suits or other fashionable wears--lest they be considered "uppity Negroes". Under their conditions of exit, it may have been unwise to attract attention to themselves on the eve of their

\footnotetext{
13 Talk about how this was the period of Americanization and that white folks were not all yet white. Cite Jacobson and Nathan Glazer.
} 
departure, as many of these men escaped in the middle of the night fleeing peonage, bondage, and imprisonment.

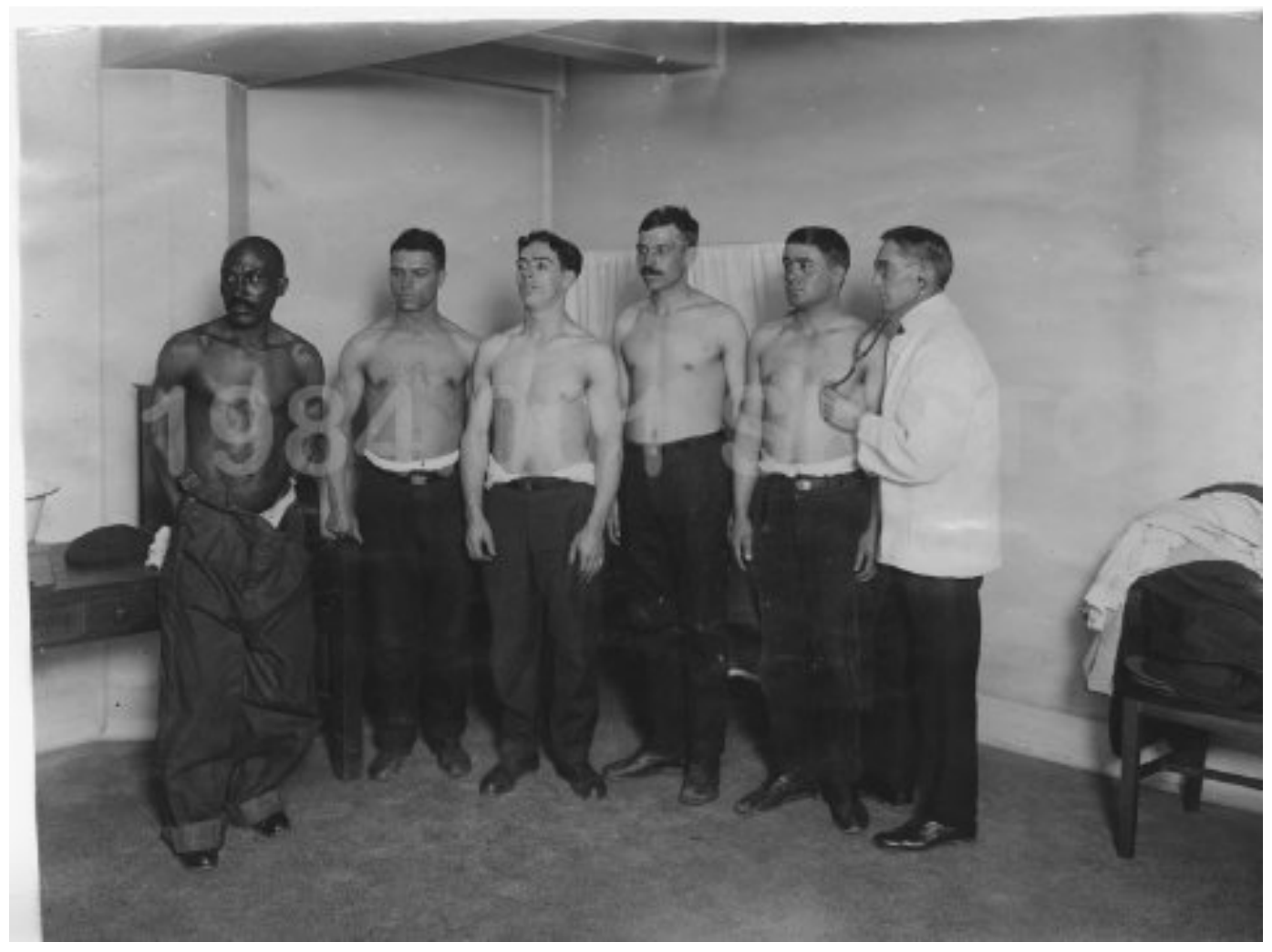

Figure 17. New arrivals getting a medical examination by company physician. Lynch, . 1920.

Reading the preceding two photographs together allows us to get a better sense not only of the historical context through which this generation of miners entered the company owned towns in Benham and Lynch, it also allows us to peer into this particular process of subject formation through the company gaze. The second photograph was taken in 1920 in Lynch, . These images were taken for two different companies, in two different company owned towns, yet we see similar content and composition in each frame. In both situations men were brought to the medical examiner in groups. They had no privacy as they were poked, prodded, ordered to remove their shirts, made to publicly 
answer questions about their medical history, and deemed fit, or not, to be assigned a position in the mines.

Racial markers exist in both photographs. With all of the men in the second image shirtless, we can see how race is also embodied. Read their chests, from the right corner of the frame to the left. Notice the definition of the black man's muscles; likely from years of toil sharecropping in the field, working from sunrise to sunset — or like my own grandfather would say about the hardships he experienced during his childhood growing up in Alabama “they worked you from cain't to cain't-cain't see when you start and cain't see when you get off." He is an outlier in his choice of dress. The only one wearing jeans, his pants are at least three times his size, to the point where he has to roll the waistband over to make them fit around his waist.

For all of these men, this scene is a clearinghouse of bodies rather than a visit to the doctor's office. However, it is in this moment of receiving a clean bill of health from the company physician that these black men transformed from peasants to proletarians; from convicts, peons, and conscripts to wage earners, to men who could send for their wives and provide for them and their children, black men who could vote and carry guns - they were truly New Negroes.

Before moving on from the images take a close look at the mood. The first group stands at attention anticipating what is about to happen to them when its their turn, while the men in the second photo are obviously listening to the command of a third party who did not make it into the photographer's frame. No man in either image addresses the 
camera directly. More than anything else, do you notice the look of trepidation on their faces?

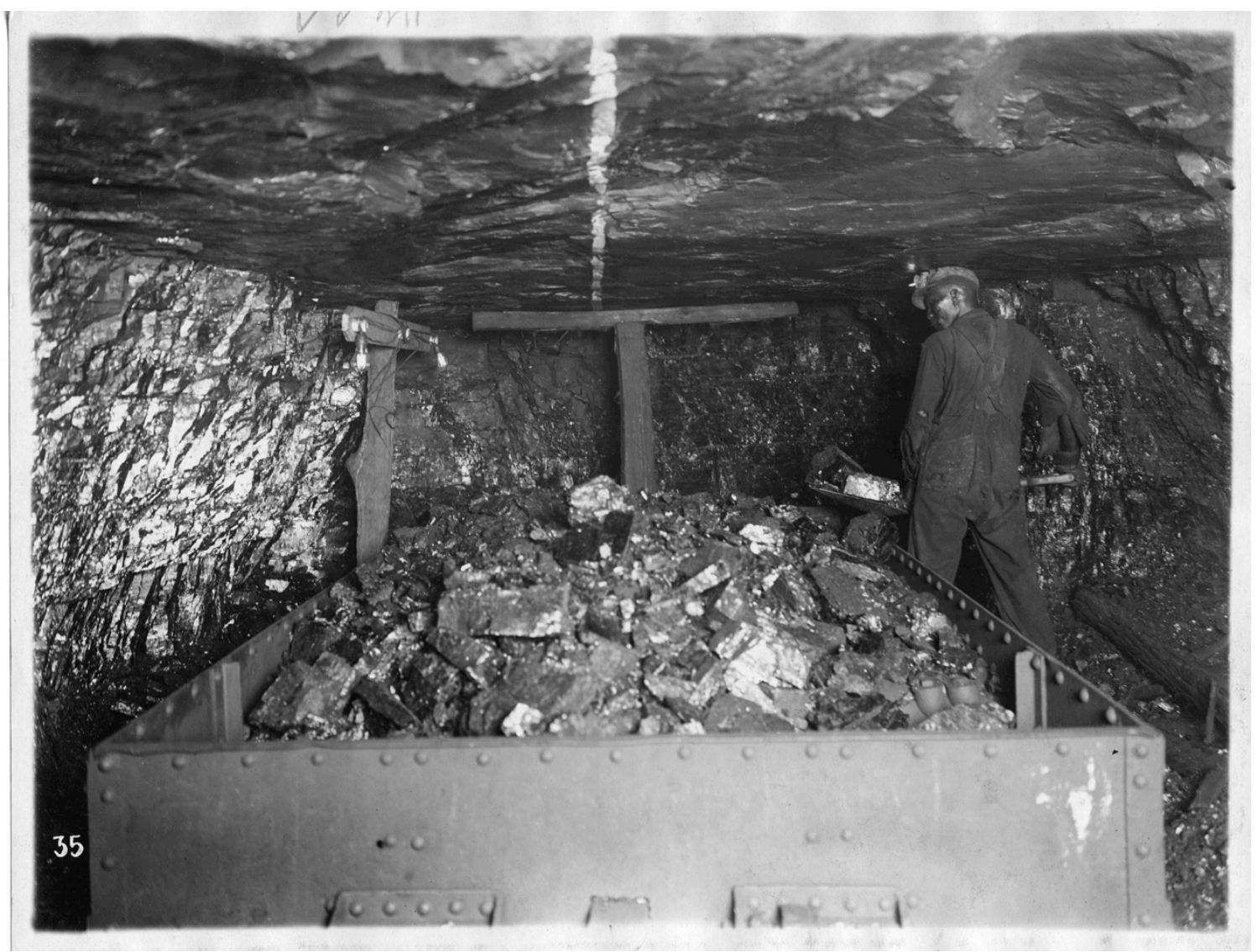

Figure 18. Coal loader in Mine Portal 31 in Lynch, . Circa. 1930.

\section{Conclusion}

Escaping the throes of Deep South did not just present an opportunity for greater social and economic mobility for black migrants in the early decades of the $20^{\text {th }}$ century, it inaugurated a transformation in their personhood. Reflecting on his observation of the influx of blacks to urban spaces during the early grumblings of the African American Great Migration, fin de siècle philosopher Alain Locke (1925) wrote, 
"The migrant masses, shifting from country-side to city, hurdle several generations of experience at a leap, but more important, the same thing happens spiritually in the lift-attitudes and self-expression of the Young Negro, in his poetry, his art, his education, and his new outlook, with the additional advantage, or course, of the poise and greater certainty of knowing what it is all about."

In his final comments in the short lyrical essay he avers, "In the very process of being transplanted, the Negro is becoming transformed."

This first generation of black migrants came to the coalfields of eastern Kentucky not only in search for a new life, but also for a new mode of being. They carried with them in their souls in that four hundred mile journey from Alabama to Kentucky were their hopes for a chance in life, for an opportunity to earn a decent wage to provide for their families, for the right to protect their children's lives from being disappeared through the physical and spiritual violence of racial hatred. What they were reaching for were, what W.E.B. Du Bois articulated in the Souls of Black Folk as, "our spiritual strivings".

Their decision to migrate to the coalmines did not come without sacrifice. Coalmining was and still is one of the most perilous occupations in the world. For the men, although most would escape the fate of death in a mining accident—although mine collapses, explosions, and deadly methane gas leaks were everyday hazards that came with the trade - none would escape the slow death of black lung. The black women who accompanied their men on this journey sacrificed their freedom by wedding themselves to a life as a coalminers' wife. With the exception of the role of the schoolteacher, these single-industry coal towns offered no employment opportunities for women and birth control was not available to them. Therefore this generation of women was saddled with multiple children — some bore sixteen or seventeen babies—and constrained with the 
doubly patriarchal structures of marriage and a company-owned town.

However in exchange for their sacrifice, these adults could offer their posterity a clean slate. In that migration they attempted to break history: they did not want to pass on their particular legacies of racial slavery and social death to the next generation. Instead this generation of migrants hoped that their progeny would experience the freedom, liberty, and equality that their own parents hoped that they would taste with emancipation. Although they did not get to experience it, the combined sensation of hope and disappointment was enough to fuel this generations' quest for another world. Grasping for words capacious enough to express what this journey meant, one participant echoes Alaine Locke:

And our black culture is not just the people from Alabama; most of them came from the South, but they came and started anew, so that's our connection-the rebirthing of a hope — you see what I'm saying? Its just like a cradle.

--Teresa Austin-Mimes | Born in 19xx in Lynch, | Resides in Lynch,

\section{$* * *$}

This chapter largely dealt with the "formation story" of the black migration into Harlan County, with the purpose of laying the historical foundation upon which this transformation in African American subjectivity emerged. The remaining chapters focus on the second generation - the coalminers' sons and daughters - and their collective experience growing up as black Appalachians. The next chapter analyzes how this next generation came to understand their own racialized subjectivity within this peculiar context. Kentucky was not the Deep South, but still a Jim Crow border state. It was not 
quite rural, yet by no means urban by the standards of a Chicago, Philadelphia, or New York at the time. Like all children all they knew was where they were. For them, their black social world emerged in the mountains of Harlan County, Kentucky-that was their home. 


\section{CHAPTER THREE}

\section{Home}

\section{Our histories are inscribed in home, "recorded in the landscape", our origin stories are in}

the land. It's a living, age-old family tree.

--Yi-Fu Tuan (1974) Topophilia

\section{...the mountain has a way of defining who your are, your character. \\ --Jeff Turner | Born 195X in Lynch, | Resides in Indianapolis, Indiana}

\section{Living Behind the veil}

In his essay "Of Masters and Men” in Souls of Black Folk, W.E.B. Du Bois

(1903) articulates both the material contours of de jure segregation and the intangible "structures of feeling" that anointed black Southern living at the turn of the twentieth century. The diaphanous cloak of the veil shrouded the hearts and minds of all, rendering mutual recognition between racial groups nearly impossible. Of the intangibles he writes, "in any community or nation it is these little things which are most elusive to the grasp and yet most essential to any clear conception of group life taken as a whole.” In internalizing the uneven structures of society, even little children embody racial ideologies and come to know themselves as little white children and little black ones. At a certain age, it is no longer acceptable for them to play together or to freely associate as friends, the cultural geographies of a single community becomes legible only through a racial lens, and at some point — each subject encounters that fateful moment of interpellation - the white child learns to call out "hey nigger!" and black one knows exactly to whom he or she is speaking. 
This chapter explores life behind the veil of the color line of which Du Bois so often spoke. My primary matter of concern in this chapter is African American subjectivity and the emergence of the racial self. Herein I seek to illuminate the ways in which the generation of black children in the coal camps of eastern Kentucky made sense themselves as racialized subjects within the broader structures of American society. Through the chapter I attend to both the particular and the universal—examining their specific experience as black children in Central Appalachia and also the general genre of black subjectivity that is conditioned by the context of living in the Jim Crow South.

\section{The Racial Self}

The Self is the result of a social construct (Mead, 1934). We come to know ourselves through our reflexive capacity to index ourselves through our experiences with others. Sociologist George Herbert Mead is clear on this when he states:

For he enters his own experience as a self or individual, not directly or immediately, not by becoming a subject to himself but only insofar as he first becomes an object to himself just as other individuals are objects to him or are in his experience; and he becomes an object to himself only by taking the attitudes of other individuals toward himself within a social environment or context of experience and behavior in which both he and they are involved.

If this is so, the question of the racial self cannot be anything but a social problem. If the individual only becomes an object to himself by assuming the attitudes of others, then how does the black subject come to see his or her Self? Particularly black folks living in the Jim Crow South, where both public opinion and law explicitly affirmed a their status as inferior and not all the way human? Du Bois' tripartite construct of second sight, twoness, and the veil are essential for considering how processes of racialization 
distort the formation of the self. Taken together, what these theorizations illuminate is that the self is an amalgam of the thoughts and feelings of others in society, what Mead (Mead, 1964) calls a "structure of attitudes", cognitively mapped onto the individual's perception of his or herself. However, this process is distorted for the black subject who receives no mutual recognition from "the other world" but instead only "contempt and pity".

Du Bois (1903) asserts that the American Negro is "born with a veil", an inescapable "structuring structure" of black life. Unpacking Du Bois' formulation of this concept, scholars have argued that the veil is "the central structural element of racialized modernity" as it "structures the lived experiences, self-formation, and perception of the world for both racialized and racializing subjects (Itzigsohn \& Brown, 2015).” Central to the conceptualization of the veil is that it precedes these material manifestations of racialization, such as segregation, differential treatment, racially hegemonic iconography. It is first a cognitive phenomena. Of this seemingly intangible level of analysis, Du Bois (1903) points out:

We feel and know that there are many delicate differences in race psychology, numberless changes that our crude social measurements are not yet able to follow minutely, which explain much of history and social development. At the same time, too, we know that these considerations have never adequately explained or excused the triumph of brute force and cunning over weakness and innocence.

A particular genre of the veil emerged in the New South after the death of plantation slavery and the emergence of the Jim Crow codes. While the codes structured the material conditions of life across racial dimensions, they also structured a racial 
subjectivity of a particular kind. Writing on this elusive dimension of the sociality of the post-bellum South Du Bois (1903) states:

But after all that has been said on these more tangible matters of human contact, there still remains a part essential to a proper description of the South which it is difficult to describe or fix in terms easily understood by strangers. It is, in fine, the atmosphere of the land, the thought and feeling, the thousand and one little actions which go to make up life. In any community or nation it is these little things which are most elusive to the grasp and yet most essential to any clear conception of the group life taken as a whole. What is thus true of all communities is peculiarly true of the South, where, outside of written history and outside of printed law, there has been going on for a generation as deep a storm and stress of human souls, as intense a ferment of feeling, as intricate a writhing of spirit, as ever a people experienced.

This final section of the chapter attends to these "elusive to grasp and yet most essential" dimensions of black subjectivity that emerged in the, pre-Civil Rights era Jim Crow South that Du Bois argued "must be answered, not by apology or fault-finding, but by a plain, unvarnished tale."

While not in the Deep South, Kentucky is a border state, and it held fast to the codes and etiquette of Jim Crow. Although the cities of Benham, Cumberland, and Lynch combined span no more than seven miles long and two miles wide, the racial landscape in each community varied starkly. Race relations in Benham and Lynch were somewhat mediated by International Harvester and U.S. Steel, shielding the black communities from spectacular forms of racial terror more characteristic of the Deep South. However the two cities differed in the extent to which blacks and whites interacted, which was largely due to the fact that Benham consisted of two camps--a black camp and a white camp--separated by a short bridge, while Lynch, at the time, was comprised of seven 
camps with varying within-camp ethnoracial population densities and racial segregation patterns. Different from Benham and Lynch altogether, Cumberland was not a companyowned town, but instead an independent commercial center established to attract whatever expendable income remained in the family household after the company store had taken its share. It also had a residential section that was populated by the overflow of International Harvester or U.S. Steel miners who could not get a company-owned house in town. With no company oversight, the brand of racism exerted in Cumberland was much more overt than that of its neighbors. This inter-city variation makes for a richer analysis as it allows us to observe the "thousand and one little actions which go on to make up life" of the veil.

\section{Going Home}

This chapter introduces the second generation of Kentucky's Coal Camp blacks- the coalminer's daughters and sons. They are the foci of this research and the remainder of the empirical chapters of this dissertation will pivot on their lived experiences; as black folks, and as Appalachian coal kids and as full fledged participants in the most phenomenal demographic transformation of the $20^{\text {th }}$ century-the African American Great Migration.

The following section "Homescapes" is a genuine invitation to enter the black social world experienced by this generation during the time of their childhood. The point of this long multi-vocal soliloquy grounds the reader in the social structure upon which their social selves emerged, so we may know the social types that were essential to the black community: "the black father", "the black mother", "the black child" and "the 
village." In this way, it attends to the universal, as opposed to the particulars of individual families. It also situates my participants as "protagonists of their own histories", which oral historian Alessandro Portelli (2009) argues is a distinguishing virtue of oral history methodology.

Selected themes and accompanying quotes reflect those aspects of childhood that were most durable and homogenous for the participants. As the study of subjectivity necessitates an examination that is close, there is no better way to peer into the interior meaning of blackness than through our participants own articulations and reflections of themselves. This form of presenting findings is quite atypical for Sociology, and it requires a different type of work from the reader - work that I can only characterize by a certain level of intimacy, vulnerability, and collective responsibility. We are doing what philosopher Immanuel Levinas (Levinas, 2003) envisioned in his formulation of a new humanism; we are taking collective responsibility "see the face of the Other." In this chapter you will get to know these people - the inner-workings of their spirit, their pain and their humor as well as their strivings. Their origin stories presented here roots this project in the souls of these Appalachian black folk.

Let's go home.

\section{Homescapes}

...well, I remember the freedom of it. I remember the mountains, friends and families and mothers and fathers. Everybody's father was a coal miner, everybody's mother stayed home unless she was a nurse or a teacher. I remember snowy days, having snow rides on 2nd Street, stealing tires from the white people's yard to make us a fire. I remember going to the Pool Room to warm up when it snowed. (Cynthia Brown Harrington) I can remember playing marbles, running around in an opened area free with 
friends, just group games: springboard, jump board, riding a bicycle that I can't remember anybody else having in the neighborhood; my little 3-speed bicycle up and down Liberty Street...(Jeffrey Ratchford)

There were a lot of children in the community, yes. And we didn't have a lot of toys, we played a lot of, you may call them homemade games... What we would do after dark is we would catch lightening bugs, they would light up and we'd catch them and put them in a jar and we also used to break them in half and put them on ears and we had earrings. We'd put them on our fingers for jewelry. Can you believe I broke a bug in half and put them on my ears?! There was also a bug called a June Bug, and we'd catch the June Bug and tie a string around his leg and we'd hold onto the string, a long string and this June Bug would fly around and we'd run around behind him until finally he would fly away from us and all we'd have is the string and a hip. That was cruel, but it was fun. (Clara Smith)

Well, growing up when I was a little guy, there were tons of kids, and one of the things that we loved to do as a little boy, we always played cowboys and Indians. We used to climb a lot of trees, we had broom sticks, and we made like they were our horses, and we would run up and down the street with the broomsticks like they were our horses. We would get a stick and break it off and that was our gun; it's like we were shooting, but that was the biggest thing that we did. And typical of boys we liked to play sports; we would ride our sleds, play softball, football, basketball, stuff like that. (William Jackson) Right and see, I will never forget...My dad brought a big old board home - it was like ten feet long, might be a foot wide, about two or three inches thick. And we would get a railroad tire, and we would play spring-board in the backyard. And my sister Ethel, I mean she could send you to the moon! She could absolutely just about send you to the moon and we would play on that till from the time we got our homework done until it was time to come in the house. (George Massey)

Wild fruit was all over the place; just walk out of your backyard right up on the hill there and there they were. They were all in different places, and when you go blackberry picking in the morning you would see a lot of your buddies, "hey I'll see you later man!"; everybody would go different ways. We would have sacks if we were going to do apples, or we would have these big buckets if we were going to pick the blackberries; and that is how we did it. Same thing with hunting; my dad taught us and brought me into hunting with a little .22 rifle, and we used to kill squirrels and groundhogs. And take them home, skin them, cook them up; rabbits, the whole thing, and fishing; we would do a lot of fishing. (William Jackson) On one mountain there was a wild apple orchard and we would take a cloth of sack up on the mountain and fill it with apples and roll it down. We would also walk along the railroad tracks and pick wild 
strawberries and those kinds of things; we would bring them home; or mother would can them. We also had hogs up on the mountain; I never saw them because the girls wouldn't go up there; my brothers had to feed them. (Harriett Hillie) Well at that time, growing up in Lynch, my dad would come home from work and he would make us go up on the hill. So many men - they would pick them out a spot on the side of the mountain and we would dig it up and make a garden. Yeah, I hated that and then we would step in and clear out all the weeds off and had to dig it all up by hand. And some people used mules. But we didn't have a mule. We were the mules! (George Massey) Daddy didn't hire anyone to come in and plough that garden. We had to do that garden ourselves...You might say it was good 35, 40 yards, yeah somewhere in the neighborhood long and about 30 yards wide. And we would plant the vegetables- we would plant collard greens, tomatoes, onions, potatoes - Irish potatoes, okra, hot peppers; all those different things. Oh we also had large chicken yards in the backyard...We'd have meat everyday. Because the hogs that we would kill, we'd start eating off of those pretty regular cause we would kill them in November, it's always the week before Thanksgiving that's when the average family would kill the hogs. (Odell Moss) ... and so in the Fall, my father would bring two hogs down. They had a big iron pot. They would make a fire and put this pot over the fire and boil the water and I believe those hogs knew that it was 'slaughtering' time because they went 'oink, oink, oink' all around the yard there. And so they'd wait until we went to school and my dad and maybe four or five other men in the community, they'd stand around smoking their cigars and whatever, after we'd left and gone to school, they would shoot the hogs right in the middle of the forehead...right between the eyes. And they slit them open and they'd hang them up so that the blood would drain down, and put them in a big tub of - a big iron pot and they would you know...pull the hair off. But I would be in school and I wouldn't know anything about it so when I would come home from school my mother and maybe four or five ladies in the neighborhood, they would be there at the kitchen table cutting up all that fresh meat, and it was red and fresh and smelling like blood, and that was the time of the year I hated. (Clara Smith)

It's very hard sometimes to really get to know a coalmining father. When I was growing up I knew more about my mother than I did with my father. My father because he worked on a night shift, he would be sleeping most of the day. So if you ask me about my father I think of him as "be quiet", don't you all have something to do like go outside and play?" I think that's because my father was more intent on getting his work and tried to keep his family together more so than he was on entertaining his kids. (Brenda Thornton) No, he was not really an affectionate man. I mean, you can see that he loves and cares about you, but he was not really affectionate. (Richard Chapman) He was a quiet man... (Vera Garner Robinson)...yeah and he didn't too much talking (Mullins 
Siblings)... and see my daddy, he was not a talker or anything like that; but if you watched him, you learned a lot. Now, that took me until my later teenage years to figure that out. (Leslie Lee) Well the problem was my father was very...he would keep a lot would keep a lot of stuff to himself. He wouldn't tell you a whole lot unless he was drinking. (Richard Brown) He was just a hard working man; he worked. (Arthur Hauser) Quiet, he was there and I knew he was there, but he worked a lot. (Terry Mason) Dad was the breadwinner. He was a man. He was strong, broad shoulders. It was unlike him to call the job and in sick. If you didn't go to work, you didn't get paid. And daddy went every day. (Arthur Simmons) Very quiet man, very very quiet. My daddy got up, he went to work, he came home, he'd watch a little television, he'd go to sleep and he'd get up and go to work and that was kind of his routine. (Porter G. Peeples)

....and he was not a disciplinarian. He'll tell you what was right, what was wrong; but he more or less lived it more so than said anything about it. (Leslie Lee) I can't remember my daddy spanking me but once. And that's because I sassed him and knew I was going it get it because I had pushed the limits. And what happened was that when I would get a spanking, I would run. So he knew I was a runner so he locked the screen door and he was chasing me around the house and I was getting ready to exit through the door and I hit the screen door and bounced back and broke my tooth off. I blamed him for that! (Virginia Ward)...he hit me one time in my life. And I cried for days because he had never put his hands on me, he had never spanked me in all my life. (Vera Garner

\section{Robinson)}

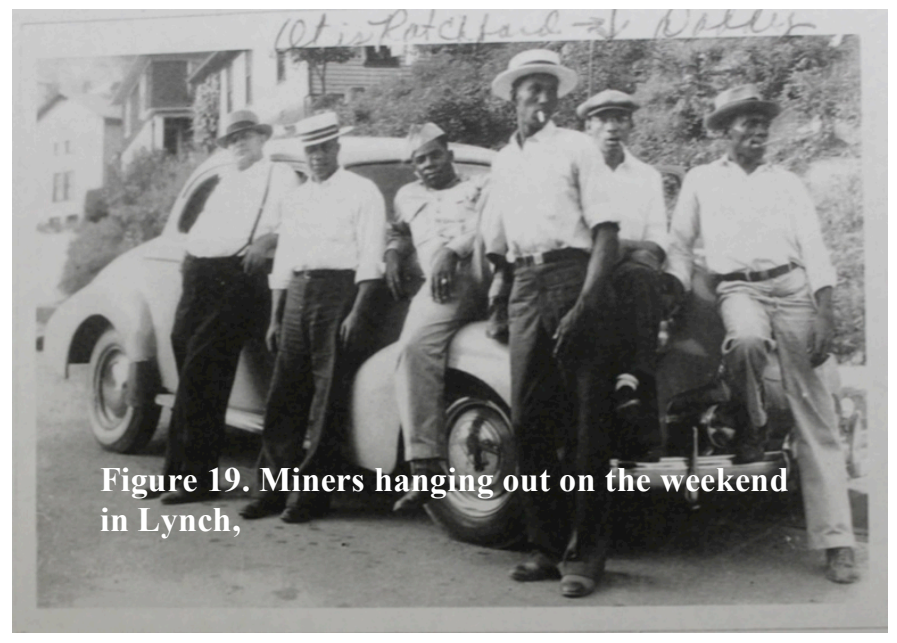

...And one thing I do remember was that on the weekends daddy used to drink. Mother used to have to go get him his nip-anytime she'd go to Cumberland she would have to bring him back his bottle of whatever he was drinking. (Wanda Davis) Daddy was a hard drinker, drinking that moonshine...starting Friday night, boy look out! They're going to come out there and drink up half a gallon of moonshine. And

Saturday they would do the same thing. But come Sunday night at about ten-thirty, they'd go to bed because they're going to be up in the morning at five on that job. And they did that every single weekend. (Willie French)

...mama would always pack an extra sandwich in daddy's lunch bucket. And it was such a treat for him to come back from work and get that sandwich. And it'd be smelling like the mines-you know, be all musky smelling. I doubt if I would eat one 
now, but boy that was the biggest thing in the world. (Leslie Lee) I just remember my dad going to work before I got up in the morning, coming home late at night and falling asleep on the bed with his clothes on. I also remember coming home from school and we would be sitting on the porch waiting for daddy to come home... and he would walk down the street and we would go meet him and we would get his lunch bucket for us - a piece of cake, whatever it was, he always left something in it because he knew we wanted it. (William Jackson) And everyday when he got out from work I could see him walking up the road and I would run down the road... and everyday he gave me his lunch bucket and he had a boiled egg and snowball cake. (Belinda Napier) He would never bring his bucket home empty. And he always had something for us to have and we thought it tasted so good--because it was coming out of his bucket. I mean, that was the mind of a child and the love of a parent. (Lena Margaret Jones)

Sit around? No way. They could not sit around. I have never seen daddy sit around in a pair of pajamas - he got up, he put his clothes on, and if he was not going to work, he was going to his garden... (Arnita Davis Brown) Oh gosh, I can just remember waking up Saturday morning and seeing all those older men in their gardens. (Katina Akal) Gardens. I mean we just had yards and yards of gardens...wherever you see a spot that's clear and you want to make a garden, you just make a garden. (Ernest Pettygrue) Oh a huge garden. My father raised all kinds of vegetables; corn, cucumbers, tomatoes, squash-he was pretty green thumbed...but he

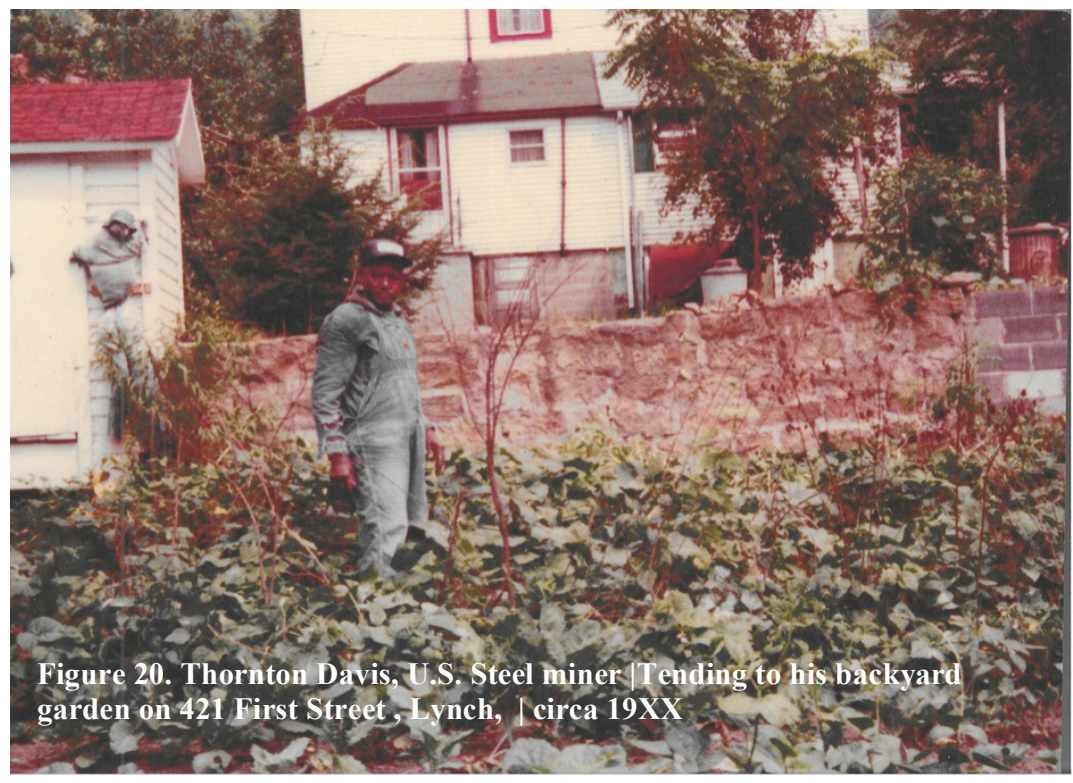
had us out there helping him work it. (Raveryn Whit) They believed in their gardens at the time. And you had to work their garden... (Chuck Rodgers) And the sons always went to the garden with daddy. After school Thornton, Michael and Kenneth would go up in the garden and help daddy with whatever needed to be done in garden. (Arnita Davis Brown)... and that's why Thornton doesn't have a garden til this day-daddy wore him out! (Patricia Davis Liggins)

Because our parents used to - there was a phrase that I daresay Karida that you are going to hear from lots of us. Our parents did not want us to have to do what they did, 
which was in the case of our fathers, working in the coal mines. So they would say to us, get your education and that's what your job is; because I want you to have the opportunities that I didn't have. (Jerome Ratchford) I wanted to go into the mine. Daddy would not let me. Oh, we had our biggest arguments about that. (Leslie Lee) Daddy told me when I was young, he didn't want us working in the coal mine. Because I told him, when I graduate, I'm going in the coal mine. He was like uh-uh, no. (Katina Akal) ...we never talked about what coal mining was like for him but he always - he and mamaalways pushed us to get an education. And one afternoon daddy and I was walking back home from the store and I said to daddy — “daddy once I get sixteen years old I'm going to quit school"... and he said "well son, the day you quit school you better have yourself a job." I said "but daddy I am your son!" He said-“"That's why." (Edgar James Moss) No, he never talked about it. He preferred you to grow up and get an education. (Geraldine Brown Kirkland)...they'd always say "get all the education you can get. That's what daddy would say. No, my dad told me to get as far away from this mine as possiblewould tell us that "I want the best for you. I don't want to see you have to go up under this earth everyday not knowing whether you are going to come out or not." (Jack French)

...my father didn't say many words. But when he did, it's like you'd have to hear him. You had to listen because when he spoke, he meant what he spoke and there was no beating around the bush. He was very stern I would say. (Mike Mason) He didn't whip us. If he tried to whip us he would be tickling us and he would say, "Here Naomi, you do it." (Mullins Siblings)... she would almost have to make him whoop us. It was not an "I want to whoop you", but a "your mama said you did this and your are going to get this whooping." (Ravryn Whit) Dad really didn't—-he really didn't say a lot. Mama did all the discipline and did all the talking and daddy just sat back and watched and he really didn't say a lot. And now then if mama could not handle the situation, daddy might step in, but that was very, very rare because mama was the disciplinarian and she didn't take no stuff. She didn't care how small you are or how big you are, she put it on you. And so you got to know that mama was in control. (Lee Arthur Jackson)

She was more of a homemaker. She didn't work outside the home. Very disciplinarian; made sure you do what you had to do. If you didn't, that little lady would wear you out. And if you thought you was getting away, she wouldn't chase your nothing. She'd just say, "you got to come to eat, you got to go to bed, you have to do something in this house; I'll get you then." And you think she done forgot about it ... (Chuck Rogers) Now, Miss Marie was the disciplinarian, I mean she was everything to the family because my dad worked all the time, but Miss Marie was about maybe five foot two inches tall and maybe a hundred pounds. But she demanded a lot of respect, and she got a lot of respect. Now my brothers, all of us pretty good-sized guys, that is when we were 
teenagers and stuff, we thought we were big tough guys, but she would break us down. And my mother and probably a lot of other mothers, would use whatever was close, whatever she could grab; the poke iron, the broom handle, the pot on the table, it didn't matter, whatever--she would hit you with it. She would throw her shoe at you, and that was life, that was the way it was. (William Jackson) Now my mom whooped on a daily basis. Daddy didn't have to whoop but every now and then - but you didn't want my mom when it came to the whooping...(Roy Stevens) Her name was Dorothy Chapman and she was a very disciplined person. You had to listen to what she said, and if you didn't listen to what she said you would end up getting the consequences that she gave you. For instance, we were sitting in the living room watching t.v. and she was eating and she told me to do something and I kept on ignoring her, and the next thing I knew she threw that fork at me. They were not going to kill you or nothing like that but you better listen. And the thing about it is that you had to respect them and you did what they said

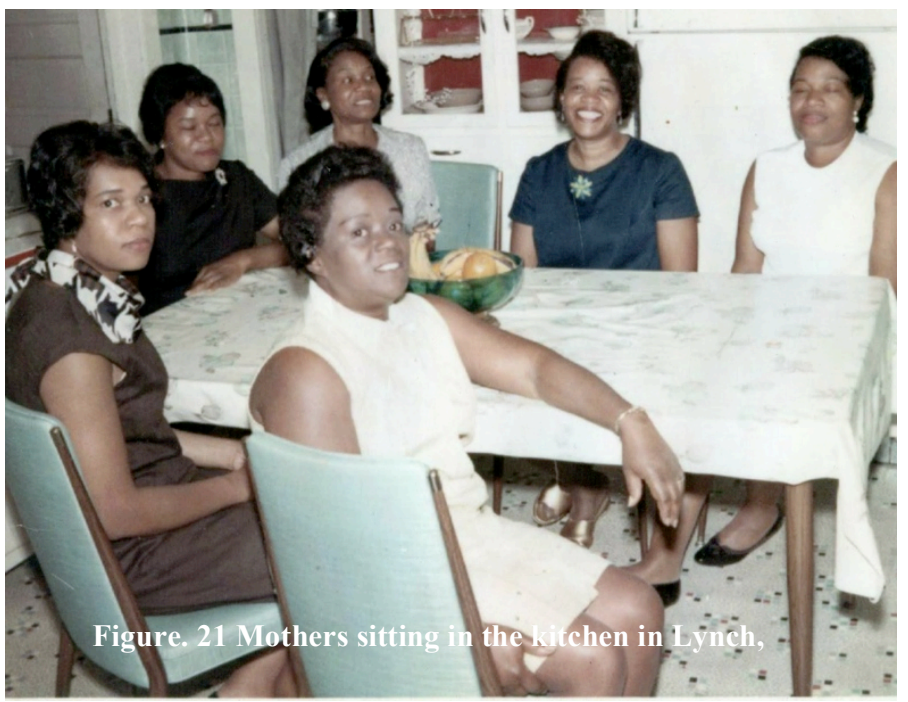
because they meant what they said. (Richard Chapman)

...stay at home mom. She didn't really have a job or anything, just taking care of us. (Deborah Williams) She was the one that was home with us while my daddy was working, so my mom didn't work. (Jacquelyn Ratchford)...but I remember distinctly how it was the mother who would run the money in our house. My father never had no damn money-Miss Punkin ran the show in our house when it came to money! My daddy would always say "I make the money and the old lady she pays the bills." And my mother would say "Earl is my mule, he in the barn, he is my worker. My parents had eight children so my mother never worked a day in her life, she never held a job. (Jeff Turner) She raised a bunch of children and there were twelve of us. She said it was more than that but this is the twelve that I know you know. I am sure she had probably had some miscarriages or something like that you know... she said she had seventeen but I can only call off names up to ten. (Lacey Griffeth) I don't know how she did it, but she raised ten children plus my nephew. And I think my mother was ahead of her time because they are trying to tell us what we are supposed to eat now, but my mother cooked from scratch; there were no preservatives, we did not eat fast food. (Patricia Davis Liggins) Sweet lady, funny, cursing. Just a sweet women. And nobody that met her knew that she cursed a lot. But fourteen kids would make you curse, I don't care who you are! And I remember she used to get up in the morning, my father would get up first and he 
would start the fire and put on a cup of coffee. Then my mom would get up and she would immediately start cooking; yelling "you all better get your asses up!" And nobody would move. And then she would be down there cooking all that food. And she would cook about two hundred biscuits in the morning. I'm telling you! And had to cook five chickens. You could feed a hotel when fourteen people are coming to eat. And my sisters ate just as much as my brothers. And it was just like feeding a hotel. Everyday we were scrambling for food and then we would be all out of pans and the plates would get broken - and we could not all sit at the table. (Richard Brown)

My mother would probably start cooking early in the morning before the sun came up... She would get up early and my father would go to work, and she would stay up and begin her chores, which we would get up and help her until we got ready to go to school, which probably started at six o'clock in the morning, so we walked to school be seven, we then carried in buckets of water to go wash our clothes. (Raveryn Whit) She'd make up rolls. Boy, and I'd be so mad because she'd be sending me all over town giving folks rolls. And Lord knows I love me some rolls! I didn't want to give up no roll. (Leslie Lee)

Just a good 'ole homemaking hard lady. She was something. She was a very religious woman, just the opposite of my dad. My dad was no religious man at all-well I shouldn't say it that way, he would be there on Sunday morning after a night of drinking his booze and doing his thing - but she was just a real Christian lady that kept us all in line. (Willie French)

\section{$* * *$}

This was the village. And a lot of times if you got in trouble, and they saw you in trouble they'll spank you and send you home and tell your parents; and then you'll get another one. (Chuck Rogers) I heard a term a few years ago about, "it takes a village to raise a child"; well that village, that is all I have ever known my whole life. Everybody in that town, it was like their child and they were like your parents. And I still can't understand how the word got around: I could do something at the ball park and my mother knew about it before I got home; I mean, I'm like, "how did she know?" the word passed but people were just so kind... We knew everybody, we knew everything and we knew our limits. And we were good kids, we were malleable, we didn't talk back; our parents told us to do something one time, and that was it; that is how we were raised. (William Jackson) Well, I think it was a fun time. It's a time really you would like to go back to. Growing up, everybody was like family...it was big families everywhere. The Brown family seemed to had 15, my family had about 15, the Pettygrue family had about 15 so it was children "coming out the woodworks" as my mother would call it you know. And so it was a fun time, it really was, some people look at it "oh coal mining camp", yes it was a coal mining camp, but it was a loving camp and everybody shared. (Arletta 
Andrews) Oh gosh, everybody was your parent. I mean everybody could tell you what to do, when to do it and when not to do it, you know and if you did something wrong they could actually spank you and oh gosh, you were really in trouble when you got back home. If you walked around the street a hundred times you had to say 'hello' to everybody sitting on their porch, in their yard, a hundred times. Even to this day, you still have to do that. Everybody knew everybody, and everybody watched out for everybody. (Brenda Clark Combs) If another adult saw you doing something wrong, they would stop you from doing it. And they would tell you "come here, I don't want to see you doing that no more" and if it is bad enough they would spank your behind, call your parents and tell what you did. And then you would get home and get another spanking. Do you hear what I'm saying? (Lena Jones)

And then if you went home and said "Oh, I don't do that"- oh, then that so-and-so is lying? Oh no, I'm not...I don't care if she was lying or if she was not lying.(Lena jones) Oh you're calling the grown up a lie [sic]?! Oh, you wouldn't dare. Even if you knew that teacher was wrong or any adult wrong you could - you're calling them a lie?! [sic], you didn't - oh you could not say that, oh no. If you thought that, you didn't go through that, oh no. You're calling another adult a lie?! Oh no, that wouldn't fly. They were the adult, they were the authority and your parents fully believed that they had your best interest at heart. And like one of the phrases my grandmother would say, if she'd tell you something and you question it. And one of her phrase is "you're 'sputing my word, you're 'sputing my word?" In other words, are you questioning me? (Albert Harris) ...oh no, no, that was just a no no, you didn't use any curse words to my dad or to any adult. Oh that was a curse word. You could not say 'lie'. You had to say "she told a story on me". You could not tell your sisters and brothers, that's just a 'lie'. You had to say "you're telling a story on me, I didn't do that, he's just telling a story". You had to say a 'story'. You cannot say 'lie'. You could not say anything like that. (Clara Smith)

$* * *$

This was their home. A community where race fully determined group membership, ordered by the inculcation of rigid gender, age, and class roles, and maintained through a hermitically sealed code of social closure: this was, what Du Bois called, their "black social world". Populated by hard working, moonshining, silent-yetstern daddies, nurturing take-no-mess disciplinarian mama's, and free flowing yet obedient children of the land; within the confines of this lifeworld, everyone knew their 
place. Mothers, fathers, and children, blacks and whites, miners and bosses, they all had a role to play in the company owned towns in Benham and Lynch, and to a lesser extent, in the neighboring un-owned city of Cumberland. In this particular context, two structures determined this generation's subjectivity: the patriarchal structure of the company-owned and their blackness.

While they were in many ways removed from the racial landscape of overt domination and terror that articulated their parent's subjectivity, at this time, they still were not quite "African American" in the sense of their right to make claims to full citizenship in the eyes of the law or in public opinion. So how did this generation experience and make sense of their blackness at the time? And how does did these free flowing mountain kids come to understand themselves as black children as opposed to children in the unqualified form? These cultural formations of the self were just as influenced by the racial landscape in the coal towns of Harlan County as they were by the context of the company town.

\section{Company Owned Subjects}

The company-owned town was a pervasive socially engineered space. Not only were International Harvester and U.S. Steel the only employers in town, they owned everything — the houses, the schools, the churches, and the stores, they appointed the clergy, hired the teachers, and deputized their own police force. Like living in Bentham's panopticon; the company surveilled and ordered everything, from actions and bodies to ideas, notions, and discourse - a project of subject formation in the purest Foucauldian (1977) sense. As their primary interest was maintaining a stable labor force to ensure 
maximal coal outputs, the companies prioritized labor before anything else. To this end, they mediated race relations in their communities. Organization of any kind was intolerable as social movements and the ideas that accompanied them threatened to destabilize the work force, including the Ku Klux Klan. In this way, there was little separation between residential and industrial spheres within the community; their very raison d'être was coal.

\section{Growing up in a Coal Town}

Men discouraged their sons and daughters from the fantasy of becoming a miner, however this was near impossible due to the pervasiveness of industry in the company. Fathers showered off-site after work so they would not have to trek black coal dust into their homes. They went over to the bathhouse to wash away any semblance of their labor. Many children remembered how "...some of the miners would come home with those dirty clothes, but my daddy changed at the bathhouse...but I never saw him in his mining clothes. (Ernest Pettygrue)...they had a bathhouse and we'd go there sometimes... and they' $d$ be in there and they'd be so black; you could not tell a white man from a black man. (Arthur Hauser) But I remember being up near where they came out of the mine. And you would see the guys coming out, and going to the shower. It's at Number Two or Number Three up to that part; they would come out of the mines. (Mullins Siblings)."

However, the sight of the miner was sublime. So much were those men in and of the earth while digging that coal, that they were unrecognizable when they came out of the mines:

And we were standing there and she was talking to him and I was a little kid. I was looking up at this man and I was wondering who is this man my mother's 
talking to? And they were talking and talking, he was pitch black from head to toe. All you could see was his eyes you know, and he was talking and she was talking, and I guess he saw me staring at him. And he looked down at me and my mother looked at me and she said "Clara, do you know who that is?" and I said "no", she said "that's your daddy". I looked at him and I said to him "daddy that's you?!". And then my hand was black, and my mother had to get some Kleenex and scrub my hand because I could not believe that was him. That's just how dirty they were...when they came out of the mines. You could not see anything on him that would make me know that that was father.

--Clara Smith | Born 194X in Lynch, | Resides in Southfield, Michigan

Even those who never witnessed their fathers faces painted black with coal, industry was all around them; it was in them. The children made homemade toys out of old mining straps and railcar tires, they made imaginary waves surfing down the waste at the slate dump, the company whistle blew three times a day with a screech that alerted the entire city to inauguration

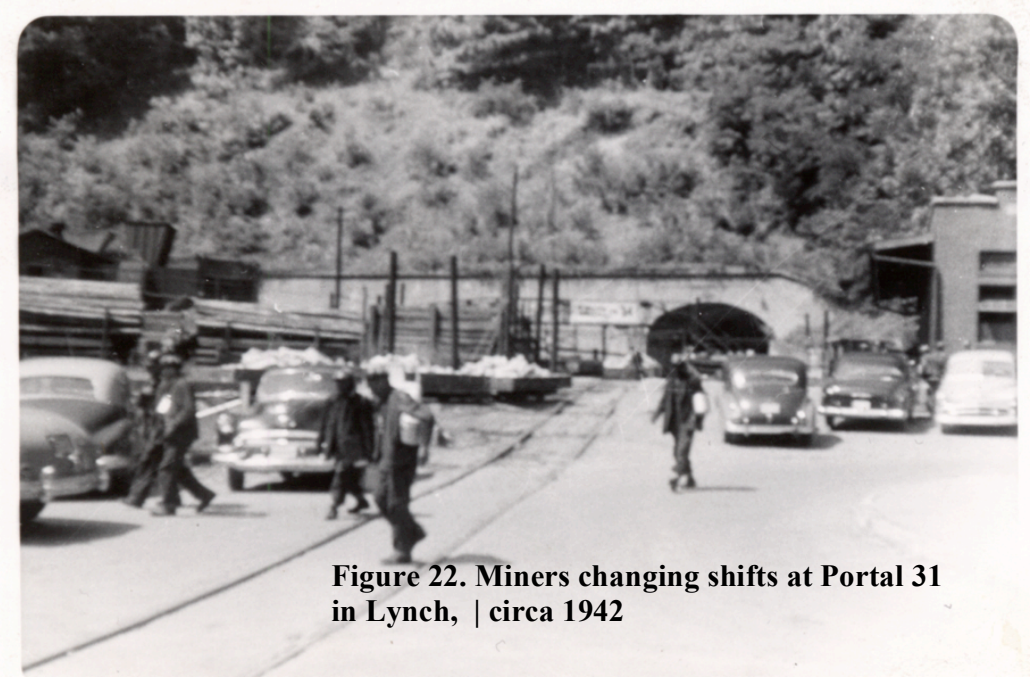

of each shift, freight cars brimming with blocks of coal chugged through the heart of town on the L\&N railroad to its final destination steel mills of the Midwest, and a diaphanous flurry of coal dust was at all times in the air. In this way, the companies shaped their identities as coal miners' children, a descriptive phrase that they have held dear to throughout their lives. 
They also were hyper-aware of the possibility that a mining accident could befall their fathers any day. Their parents' was the generation of manual extraction-coal loading, dynamite, and pick-and shovel digging. Mine safety procedures were not yet an industry standard and human life was considered cheap to the companies.

Well, daddy was in the mines in the late twenties and thirties. And at that time, what they would do; every man would have their own little tunnel; and what you would do, you had the little pick and shovels that were short and had a long handle on it. And you dig the coal and rake it back behind you; and as you went in, you would pin the ceilings so it didn't fall in on you. And what would happen is that they would weigh out your coal, and you get paid accordingly. --Leslie Lee | Born 1947 in Lynch, | Resides in Harlan,

The chance of a mine collapsing killing one or all of their father's was real, and as children, the unspoken understanding that their family could be next is the tie that binds all mining families. Memories of the ambulance sirens, broken and dismembered parts, and gurneys and hearses were just as every day as the sounds of the red robins chirping and the sight of the blackberry and apple orchards blossoming.

...when you'd hear the ambulance going down the street you never knew whose father was in that ambulance. And sometimes it was my father, like there were several times he got his leg broken in the mines. (Arthur Hauser)...the danger came when they had caveins; because that's what happened to my grandfather. (Betty Williams)... and that's where my grandfather got killed in the coal mines. A rock or something fell on him and killed him in West Virginia. (Roland Motley) I'll share this story, how my father's cousin-Theodore Jones was his name--he got his hand cut off in the mines. And I remember going to the house he lived in and dad, he took the hand and wrapped up in some newspaper. He took it to the church, at Mount Sinai church, and put the hand in the furnace.... and I would say that it was dangerous but they didn't talk about it. (Mullins Siblings) 
They were also witnesses to some of the most violent labor wars in American history. John L. Lewis was a hero in every miner's household, and Harlan County was the last battleground in the central Appalachian region in the fight for unionization through the United Mine Workers of America (UMWA). In these ways and more, the coal mining industry was in them.

Oh yes, I remember vividly about United Mine Workers of America. He loved John L. Lewis, he loved the union. Daddy said it used to be so dark in the mines and the rats would be big as dogs. And they'd be crawling into that mine and they'd be below all day long...(Arnita Brown Davis) It was not nowhere as good until John L. Lewis came in. And then they had to pay you, they had to write you a check and you could go to the bank and get your cash and all that...don't get me wrong, it was a good living for our fathers, but they had to spend it all here. (Bennie Massey) One of the reasons why they started calling us "Bloody Harlan" was because people would get killed over there. It doesn't seem real, but it happened...(Raveryn Whit) In the '50s they had a strike in the coal mines, and I had heard about the strikes and all that, but this was right in our neighborhood. Somebody blew a car up. (Betty Williams)...they had a strike one day and we had to get under the bed because the union and the coalminers were shooting each other. They were shooting across the mountain, people over here were shooting, people over there shooting - one of my aunt's boyfriends got shot, he was a coalminer. (Robert Pollenitz)

\author{
$* * *$ \\ In an era of paternal capitalism, the companies were very involved in all aspects \\ of life in Benham and Lynch. The goal was to create a paternalistic relationship between \\ labor and capital, through which the laboring class would gradually forfeit their belief in \\ their own agency and instead come to view the company as an omniscient, omnipresent \\ being that controlled their destinies. This particular type of company-owned subject was \\ formed through a balanced between ideological and repressive apparatuses of \\ domination — calculated doses of gifts and fear — engendering within the psyche of the \\ miner and his family an engrained sense of indebtedness to the company. In his analysis
}


of paternalism in Harlan County, , Italian historian Alessandro Portelli (1990) wrote, "the subordinate subjects of a paternalistic relationship have no rights, but they may receive gifts--the replacement of the right to a safe mine with the gift of a sack of flour.” The concept of giving was inextricably linked to that of ownership. No one "owned" the material conditions of their livelihood, instead the company "gave" it to them. When asked about the extent to which the company was involved in everyday life, one participant reflects:

Very involved. Not so much with us as children but very much involved with the experiences of our parents, because they owned everything. They owned every thing. And so decisions [for example]-you cannot live in housing without abiding with the standards that United States Steel established. And if by chance a husband was deceased, that lady could no longer live in those houses...they owned the houses, they owned the mineral rights under the houses, they owned the commercial outlets. And the same thing was also true of Benham, it was International Harvester, which was also a major top five hundred company at the time.

--Jerome Ratchford | Born 1940 in Lynch, | Resides in Atlanta, GA

This super-involvement was a double-edged sword. On one hand, miners provided their families with guaranteed housing, food, and protection from external economic shocks. Even in situations when there was not enough money to cover the household expenses, miners and their families could use credit at the company store. In fact, up until the mid 1950's, International Harvester and U.S. Steel paid their workers in company scrip instead of normative forms of U.S. currency. A mechanism to keep laborers tethered to their jobs, the scrip system lent a false sense of security amongst children:

...we had a good life because we had the company store and we had scrip. And it was just a beautiful upbringing because it was kind of a Utopia during World 
War II because coal was King, it was our main source of energy. So we had it made pretty well.

--Ike Gardner | Born 1936 in Marion Junction, AL | Resides in Chicago, IL

In most cases, awareness of the extent to which the seemingly benevolent

company controlled their lives only arose with the direct experience with death,

disruption, or displacement. Only through these moments of discontinuity did participants

become aware of how disposable they were to King Coal: just as the company giveth, the

company taketh away. Although the coal towns involved a different set of actors, the

mechanisms of control in the coal towns were not unlike the sharecropping system.

\section{Jim Crow and the Emergence of the Racial Self}

...down there, there were areas you could not go, you could not go to the pool. If you wanted to swim you had to go to a swim hole around the river. There was a beautiful pool in Cumberland but you could not swim in it, there was a playground but you could not go to it. You knew your place and you knew not to go to those areas. Your parents told you you're not allowed here, you were not allowed there, so you didn't cross the line. (Virginia Ward $\mid$ Cumberland) Black girls could not take ballet, not in my town. (Brenda Nolan $\mid$ Cumberland) It was very racist, but we were unaware of it. I mean, we rode the back of the bus and there were neighborhoods you didn't go in and you didn't live in... The racism was institutionalized--there was a little store in Lynch--now the institutionalized things said that if you were black and were in line to pay for your groceries and somebody white came in, they got in front of you. I mean, that was just the way it was. But none of that mattered because we had our own fun, you know? (Leslie Lee $\mid$ Lynch) But behind the track it was black, and the white folks lived on Main Street, but they got along pretty well together. They had baseball teams. The whites had a baseball team and the blacks had a baseball team. But I don't ever recall them playing each other, you know? They were segregated but it was in a kind of way that "you don't bother us and we don't bother you", you know? (Ernest Pettygrue) It was hostile, but we didn't notice that and I think it was because of the coalmines. It was separation. Now when you got close to where that bridge was, blacks would be on one side of the street and whites on the other because that was the dividing line. (Betty Williams) I didn't know black and white. We went to a black school...we stayed in a black area. We had two or three camps, so you didn't know it...We also had so much fun and playing and all that that you didn't see it. And when we were playing sports we just played other black schools. And you just felt that's it and you didn't worry about it. (Ron Thomas $\mid$ Lynch) Black kids could not go into those type of places; we could not go up to the Lynch 
country club pool. (Jeff Turner | Lynch) I remember the theater -you know, it's segregated in Benham theatre too. So you come and pay and then you go upstairs, you could not sit down with the white people. But in Benham I didn't realize it, even though I knew whites went that way and blacks went that way. But all of them worked in the coalmine together, but when they came out they went that way. (Robert Pollenitz | Benham)

That's Just the Way it Was...

Racial segregation is one of the fundamental techniques for reinforcing racial difference, inextricably linking the relationship between race, space and place. As it relates to racial consciousness, it is not only the fact of segregation; it is the way it is practiced and performed in everyday life. This everydayness of processes of racialization normalize difference, while the "structuration", referring to the ongoing interaction between structure and agency, legitimizes it. What is sublimated from these dual conditions is taken-for-grantedness. As children growing up in Lynch, few were aware of the racial prejudice embedded in the act of separation, instead that's "just the way it was":

No, no, because I knew that that was just segregation and all that. And because they didn't use the same bathrooms as we did during those times and things like that. You know, wherever you go, there was one side for the white and one side for the black and you know, no, I never questioned why.

--Arthur Simmons | Born 1937 in Lynch, | Resides in Chicago, IL

Well, I never paid too much attention to it growing up because we always had the same personality you know, we had special days and well I knew that about the segregation part, we had special days that we could go to the show and we had to sit in the balcony. But we didn't pay too much attention in that you know; we just took it for whatever its worth because that was the way it was. -

--William Schaffer | Born 1926 in Lynch, | Resides in Chicago, IL 
I think there were but I can't really recall now because I was so young when I left, I don't know if I just knew that that was what was supposed to happen, you know growing up there and that's all I knew. I knew to go to the back of the bus, and I knew to go through a certain door. I think it's from going to the store with my parents. I learned what to do and what not to do.

Clara Smith | Born 1942 in Cumberland, , raised in Lynch | Resides in

Southfield, MI

Although ostensibly benign, this taken-for-grantedness is by no means inconsequential on black psyche. As children, every time they walked into separate schools, took their seats in separate sections of the movie theater, walked home to separate neighborhoods, they came to embody the racial ideological structure. Political theorist Anthony Bogues (2010) points to this feature of racial domination, what he calls the "ideological weight of colonial domination", in Empire of Liberty where he makes clear that "it was not just a matter of the ways in which dominant ideas worked by setting limits or establishing horizons that were then taken for granted. Instead, those ideas were inhabited and then came to map our social world." These moments of active separation birthed in the minds of young children an ideological tabula rasa of the racial order of things.

The three excerpts above are illuminating as they demonstrate how we inherit the world into which we are born. Their unawareness did not stem from an ontoepistemological understanding of their own racial difference, it was always already there for them to inherit from historical ideological structures into which they were born. While their explanations differed; with Simmon's through embodied practice, Schaffer's through cultural affirmations of "us" and "them", and Smith's through intergenerational 
transmission of knowledge, however what links their experience is that they were all "born with a veil". The level of their racial consciousness in terms of their oppression was in large part explained by the extent to which they shared amicable, albeit strangerly, social interactions with whites. In his attempt to distinguish the character of the racial landscape in Lynch from that of his neighboring communities and the Deep South, Jerome Ratchford explains:

...and things were loosely segregated in Lynch. And this is a term I'm formulating here, loosely segregated. There was not the rigid strict segregation that you know to have occurred in the Deep South and some other places and so forth. So we for example, I don't remember separate water fountains, except when I went to Harlan and you could see the signs. I don't remember that, okay. I daresay that was nothing like that in Lynch.

Indexing Lynch and the Deep South is a discursive move that runs through many participants' accounts of race relations in Benham and Lynch. This is natural given that the markers of what counted as "racial oppression" in their parent's generation, i.e. lynching, abduction, convict labor, and open rape, were not visible in the lives of their children. In this sense, the distinction "we were not like Alabama or Mississippi" was a signal of progress for this generation of Appalachian children. For example, Lynch, Kentucky natives explain, "I mean we understood the prejudices were there but it was not as pronounced as it was say in the Deep South like Alabama, Mississippi or some parts of Tennessee." (Ike Gardner | Lynch) ...but then in Lynch we grew up with a system of separate but equal. And most blacks did not have to deal with the racial deal as in Alabama so to speak. Usually were not aware of it you know, so and that was a little bit different there in Lynch to me growing up you know." (Sam Howard, Jr. | Lynch) 
However, normalizing current oppression in this way against the backdrop of historical oppression in the name of progress is a common theme of modernity. Our conversation continued and I pressed Ratchford on his assertion that Lynch was an exception from the city of Harlan, just twenty-one miles away, and the Deep South writlarge. Aware of the many sites of segregation in Lynch, I prompted, "Now, I have heard accounts of the movie theater..."

Yeah, but there were - that's what I mean - but there was a balcony, obviously in movie theater. And blacks sat in the balcony and whites were at the lower level. There was also - but if you take bus travel; I learned, having grown having lived for a period of time in the Deep South, there was strict enforcement which is ridiculous, but where you could see it and so forth.

In Lynch, there was understanding that you cannot sit beyond a certain point; but there was no intervention if someone sat somewhere that they were not -"supposed to sit." And if I can go back to the major department store; there were absolutely separate counters in proximity of each other that blacks sat on for their sodas and their ice cream cones and so forth; and white. But that was like an imaginary line, there was no, "this is for colored, this is for whites." There was no such signage there. So there was some things that were understood and so forth, and then there were some things that were sort of orchestrated and cemented such as balcony and what have you. So there was a loose - things were loosely segregated. But now if you went outside to Harlan, you saw a manifestation that you would equate with the Deep South, yeah.

--Jerome Ratchford | Born 1940 in Lynch, | Resides in Atlanta, GA

Upon further reflection, Ratchford illuminated for us the various ways in which Lynch was in fact segregated in the same manner that one might find in downtown Harlan or even in Selma, AL. However, for him it was the politeness of it all that made this brand of racism tolerable, largely due to the sense that he was in many ways able to maintain his dignity--albeit as long as he did not cross that "imaginary line". 
So ingrained were the hegemonic structures of racial domination, few participants were even able to recall if there were in-fact signs that restricted their actions. What they remembered instead was that "they knew their place."

Oh, you could not sit in the front of the bus. I'm sure the bus driver would have said, "you need to get back in your area." But you knew not to do that. I mean, why would you when you see "colored" back there? And I rode the bus a whole lot. I can go on and tell you after everything was integrated what happened with that, but you knew your place.

--Virginia Ward | Born 194X in Cumberland, | Resides in Dayton, OH

Friendship as a Proxy for Mutual Recognition

I often used questions about friendship in the oral history interviews as a proxy for mutual recognition. Beyond interracial contact, which really does not require true communication or intersubjective understanding, friendship signals a mode of knowing somebody. On the surface, responses to the question "did you have white friends?" varied, as their conception largely depended upon the extent to which their neighborhood or "camp" was segregated, however when pressed with follow-up questions about the quality of those relationships, it became apparent that their social world, no matter the level of interracial contact, was completely black.

...I had white friends living right beside me growing up, but we didn't go to their schools, we didn't go to their recreation facilities. (Sanford Baskin $\mid$ Lynch)...I grew up with white friends and most of my classmates would say that they had white friends, if not acquaintances; played sports together, et cetera. The main segregation was the schools. (Jerome Ratchford $\mid$ Lynch) Not in Kentucky. In Kentucky they had different areas that were designated, like number five had a street that was totally White. The hillbillies were White and I was friends with them but they were not really close friends. The closest that I came to as far as seeing a White person in my life was the milk guy, he was very friendly and he was White. And he would come every week and he would deliver the mail and ice-cream and sometimes he would give us free sample and whatever and he 
was always glad to see us. So it was like he was the only White person that we knew outside that would come in our community all the time. (Brenda Thornton $\mid$ Lynch) Not til we integrated school. I mean, there were some who would speak to you. (Leslie Lee | Lynch) Oh no, not down there. The schools hadn't integrated, because that's what brought about that, once the schools integrated. (Betty Williams)

These friendships were limited in the sense that they did not lend themselves to the same "village"-like familiarity that they were used to within the black community. That became apparent when I asked those who claimed to have white friends if they ever shared meals in one another's homes:

...we didn't. I can't remember going into their houses to eat. (Sanford Baskin $\mid$ Lynch) No, that was not common. That would be a select instance where that occurred. So yes, I did do it once or twice but that was unique to our respective families. That was not something that routinely occurred. What did occur that was interesting is that while we could not go to white social events, say a dance or something of that sort, whites frequently came to black social events. (Jerome Ratchford $\mid$ Lynch) Well, we may not have gone to each others' homes to eat...we were good friends in the classroom and in the neighborhood but no we didn't share homes. They didn't come and sit on your porch, it was still segregated in that way but you could walk to the store and see each other and talk. (Arnita Davis Brown | Lynch)

Thank God I Knew How to Run...

Those who claimed not to have experienced prejudice in their daily lives as well as those to had been unaware of the racist structure of their lived environment were still vulnerable to unadulterated, sublime encounters with the veil in all of its omnipotence. Like a bolt of lightning, these flashpoints made hyper-visible what they subconsciously understood all along: the precarity of blackness. Brenda Thornton was born and raised in camp number five in Lynch. As she shared in the earlier excerpt the only white folks she had encountered as a child were the hillbillies who were kind of her friends but not really, 
and the milk man; other than that her social interactions were experienced within the veil of the color line. Only from time to time would she and her siblings venture out of their community on their own and leave the security of the black social world:

When we were walking sometimes we would go through the white community and sometimes somebody would come out and call us nigger or whatever. But the other thing that I remember too is that was not directly in the area where we lived at because it was segregated. But when we went to the big store we had to travel through some of these areas that were white. Before we reached the hospital - and I think it was on Church Street - these people would always sic their dogs on us, they were boxer dogs. So we actually really had to run for our lives with these dogs...And still to this day, if I see one I still have that fear. Thank God that I knew how to run very fast. Sometimes they were mostly kids but sometimes the adult father would egg the kid on. And there was always one particular house at the end, before you got to the hospital that would do that. They would think it was funny and they would wait until we got up there and sic that dog out there on us. And we were kids. It could have killed us but they thought it as funny. I remember that. And we used to always take something with us to protect us, either pick up a rock or something like that. But as far as passing people on the street, coming out of the store or even being in the shopping area with them there was no problem. And I could not understand it, I said to mama, I said, "why is it that we could go into the big store and we could be in the area up there buying anything else and they walking around but as soon we go into the area that's considered to be segregated then they start picking?" Lynch was weird. And you're not going to understand why when they were underneath the ground in the coalmine - I mean, and they all got out and they all had black faces, they all looked alike and they were all down in that whole. And there was no difference. If you got hurt down there and you're a coalminer the other one would help the other one out. They were brothers in the coalmine but they were enemies outside. It's just weird. I don't know.

Brenda Thornton | Born 1950 in Lynch, | Resides in White Plains, NY

Thornton and her siblings somehow understood what it really was; that when those men and boys loosed those boxers, it was their personal responsibility to save their own lives. No officer would come to their assistance, no white neighbor would chastise the perpetrators for their actions, and that those dogs could consider it a reward of service if their teeth and tongue could rip into the flesh of one of those black children. In her 
explanation there was no indictment on the whites; because the onus for her life was on her. For that all she could say was "Thank God that I knew how to run very fast."

Running for one's life was a recurrent trope used to describe the moments when the foil of politeness was exposed and the veil laid naked in all of its terror. In describing the race relations in the city at the time of his childhood George Taylor remembered:

...well we experienced a lot of it...when I was maybe eight or maybe nine years old, some of us would go downtown to the new area and we'd be heading back and some of the older white people come up and would say "Nigga's what are you doing downtown?" and "You know you better not come down here!" and all that stuff.

Karida: To kids?...

Yeah, to kids. We was eight, nine years old and we would go to this railroad track and we would have to go walk at the railroad track and those guys would say "You better get to running!" And we would have to run all the way home because they would come and act like they were running after us, something like that. I know a number of times at night they would really run at us because they knew was not nobody out to see what they were doing to us, you know, stuff like that.

--George Taylor | Born 1950 in Cumberland, | Resides in Dayton, OH

Desire, Envy, and Moments of Inferiority

In the eyes of the blacks and I believe always is being if you are black stay back, if you are brown stick around, if you are white you are all right. And that's the way it was even in the black neighborhood to be of a dark complected person was not too good for that particular person. They'd have their problems and by the same token being too light you were told about your complexion et cetera.

--Sam Howard, Jr. | Born 1942 in Lynch, | Resides in Louisville,

They can go and buy what they want to buy. They bought all the candy and all that other stuff and we'd see a white boy that was somewhat our friend and all of a sudden I am trying to get candy from him and stuff like that. (George Taylor | Cumberland) I used to want to be like Charmaine, I used to want to be white. I envied something about her. I 
envied the fact that she had everything. She had all the dolls and clothes and the beautiful house and I wanted that...In fact, I can remember that Christmas time came, and my mom bought me a black doll and I didn't want it. I threw it across the room because I wanted a white doll. (Virginia Ward $\mid$ Cumberland)...you know because back then we didn't call Negroes “black”. Those were fighting words. (Vera Robinson)

\section{The Spectrum of Whiteness}

White is a $20^{\text {th }}$ century formation. Up and through the 1950 s there were dozens of phenotypically white "races" in America, such as Irish, Italian, and French, let alone Slavs, Tuetons, Cossacks and Iberics. American Studies scholar Matthew Jacobson calls this the "epistemological crisis" of whiteness (Jacobson, 1999, p. 2). The 1920s hearkened the beginning of "Americanization", an assimilationist movement aimed at transforming the European immigrant into a "new man". Efforts to accomplish this newness including forsaking the use of ethnic cultural symbols in public, such as native languages or dialects, ways of dress, and foodways (Glazer, 1993). Even through the 1940s, 50s, and 60s, the structure of whiteness had not yet tempered itself to the point that the privilege of whiteness was extended to groups on the basis of phenotype or continent of origin.

This epistemological crisis was especially pronounced in the cosmopolitan canopies of Benham, Lynch and Cumberland where the coal companies made intentional efforts to recruit a diverse European immigrant labor population through the judicious mixture policy. Contra to the assimilationist sentiment that were championed amongst American citizens and institutions at the time, International Harvester and U.S. Steel were invested in reinforcing transatlantic ethnic solidarities through the ethnogenic articulation of space and institution. For example U.S. Steel intentionally built ethnically centered boarding houses and churches throughout the community to ensure that the 
Greek, Slovenian, Hungarian, Italians, and other highly represented ethnic groups continued to identify with their "fellow countrymen" first, miners second, and some gradation of white third. This form of ethnocentric social engineering was reinforced by company-sponsored events such as concerts by famous entertainers from their homelands. These measures to reproduce an obscured "we" were taken to suppress unionization efforts from mobilizing throughout their labor force.

What this meant for blacks, particularly the black children was that their racial selves emerged not only within the context of a white-black binary, as their parents had experienced in the Deep South, but vis-à-vis a spectrum of whiteness.

...and there were those who were equal and probably some white families who were more superior. But at that time you would have to realize that they were foreigners and if you were from the boot you know that's one of the ways of learning geography. You learn very young that the boot is at the bottom of Italy and those people are dark Italians and so they are different than the English and the French or the Germans so they are not supposed to be with the upper crust white folks and not only that Hungarians, the Slavs, the Czechoslovakians. There were people who came to work in the mines from those countries and who lived in the community not necessarily in Sawmill Hollow but in Cumberland period and they were just to step - and in fact in some instances they may not been equal to the Negro treated as the same as Negroes or colored people. And many of the white people of a certain class didn't fraternize or socialize or even go into their businesses.

So and there was a class difference both economically and otherwise. And as an example in Cumberland - there was a place you called New York. Well, in New York that's where the business class white folk lived. And if you wanted to make some money washing windows or washing walls or cutting grass then that's where you would go and you go down the street and you knock on doors say you have any work to be done.

And so they were the upper-middle class of Cumberland and they had attitudes about Catholics. There was a Catholic church in Cumberland. But and I think they had a school, a small school at the church but it was not - they were not treated the same and you know they didn't have the same status as the white people. 
--John Steward | Born 1942 in Cincinnati, OH; reared in Cumberland, | Resides in Aliso Viejo, CA

Whiteness was constructed on a origin-class continuum, and institutionalized through spatial ordering, where the "real white people" lived in the completely segregated upper echelon neighborhoods, while the as yet white folks lived amongst the element. Those who shared ethnic origins with countries such as Hungary, Poland, Yugoslavia were considered to be white folk of a different class. Even as children, blacks were aware of these ethnoracial distinctions of whiteness, they also understood that their blackness anchored the spectrum of the racial order. One way that racial knowledge was affirmed was through geography both real and imagined. John Steward points to both "the boot" of Italy but also the cultural geography of his own childhood neighborhood in Cumberland, , where the "upper crust" whites lived in one section and the Othered-whites lived amongst the blacks. Knowing little to nothing about Europe, let alone Italy, Steward mapped on the symbolic meaning of otherness onto the geographic landscape of Italy as he saw it manifest in his own neighborhood. Another more intersubjective way that black children were able to classify the social hierarchy of whiteness was by whether or not an ethnic group was known to socialize with them. Speaking of Hungarians Virginia Ward remembered that "they would socialize with Black people because they were not wanted there, I mean, they were foreigners. And the White people didn't treat them well either." What black children like John and Virginia understood was that the element that created the possibility mutual recognition across racial lines, the nonetheless tenuous relationship between Hungarian and Black, was the one characteristic that they agreed they shared in common: their unwantedness. 
Ironically the group that occupied the space of the ultimate Other existed as the uncounted in the imaginations of all inhabitants of the mining community. These were the descendants of the people whose had settled in the land centuries ago. In a similar way that they had stripped the native peoples from their claim to belonging to the land generations ago, the coal mining industry transformed the mountaineer into a persona non grata. Today scholars refer to them as mountaineers, but back then folks called them the hillbillies.

\section{The Great Equalizer}

Economic markers were the prevailing empirical way in which they as black children evaluated racial difference. To them it just seemed as though the white kids had everything: homes on Main Street, nicer clothes, dolls that looked like them, and echoing George Taylor's earlier observation, "they just had all the candy." Yet and still, that perception of difference was greatly mediated by industry. Coal mining is a very fraternal occupation in the sense that in the mines, while under the earth everyone's lives are on the line. Coming out alive depended on one another's trust and cooperation. Similar to the type of brotherhood mentality that is associated with dangerous occupations such as firefighting, crabbing, the military, and law enforcement, coal miners stick together. The fact that their father's shared the same occupational status as everyone else's in the community had an impact on how black children perceived their status vis-a-vis their spectrum of white counterparts. In discussing inequality participants were sure to distinguish their perception of differences of race from those of class. Common responses pointed to the coal mining industry as "the Great Equalizer": 
Well, the mines were the Great Equalizer. Everybody was buddies, you know? That's the way they were, they were buddies. (Leslie Lee $\mid$ Lynch) The fact that your father worked in the mine that made you equal across the board—black and white—so I, maybe I think I was naïve in that way that I didn't really know that kind of order. (Arnita Brown Davis | Lynch) When I was growing up, the company owned all the homes in Benham; everybody worked with the coal mine; everybody was making the same amount of money, there was a mother and a father in the home, otherwise you didn't live there. (Harriet Hillie)

Black and white miners worked together, organized together, and even lodged strikes against the company together. They knew each other's plight, were all controlled by the same paternalistic corporations, and they were all breathing in that black coal dust that slowly took their lives. In the end, these miners and their families were all striving for their children to attain a role in the American dream-education, the opportunity to thrive economically, freedom, success, safety, choice - they wanted them to have a chance at the good life. However the ideals of brotherhood, camaraderie, and mutual recognition broke down outside of the field of labor. Race relations in the mines at Benham and Lynch can be summed up between two recurring statements that exist within the body of oral history interviews:

...he would often times talk to me about the black and white side of the coal mines. And he would say when you go in that hole every day you go in even and when you come out your are dark. You can't tell a white man from a black man when you come out because you are dirty and you are completely sandy.

--Jeff Turner | Born 1959 in Lynch, | Currently resides in Indianapolis, IN

...they would work side-by-side with the whites everyday. But when they came out the mine they had to go on their section of the bathhouse and the whites had to go to their section of the bathhouse. They would then go to the restaurant, they would go into their side, the black side. And they would go on the white side. After they worked all day together.

--Lena Margaret Jones | Born 1938 in Lynch, | Currently resides in Louisville, 
They would go in everyday as equals, and if they were lucky enough to come out at all, they came out black. Yet the entrance of the bathhouse was a threshold of subjecthood, in one step those men would transform from miners to black men and white ones-and never the two shall meet.

The company also involved itself directly in racial matters. They took measures to regulate behavior by proscribing interactions that were deemed intolerable to the company's mission or to public opinion. For example, fear of miscegenation loomed large in the white psyche, and to deter white community members from taking matters into their own hands, the company stepped in to censor that behavior.

....and then plus US Steel had strict laws up there. Because I remember a caseWillie Mike-Willie Mike Powell on the choir was dating a white girl; everything was consensual but he got caught and so the girl didn't say he raped her; but they had an unwritten law that he had to leave Lynch or his daddy could not work there anymore.

--Ike Gardner | Born 1936 in Marion Junction, AL; raised in Lynch, | Resides in Chicago, IL

If a father lost his job, that meant that everyone had to go. With ten, eleven, fifteen or sixteen mouths to feed, that was no small threat. The company also intervened in supporting sites of cultural production along ethnoracial dimensions. For example, the companies sponsored lively Fourth of July celebrations every year, replete with games and competitions in the baseball park, free ice cream doled out by the company store, and parades up and down the streets of the several coal camps. Although, everyone acknowledged the holiday, it was generally understood as "white folks Independence 
Day". However, the company would sponsor an equally spectacular celebration one month later for the Eighth of August — the black folks Independence Day.

The coal company's role in affirming and destabilizing racial epistemologies cannot be ignored. Being a coal miner's kid generated a strong sense of pride and dignity within the hearts and minds of the black children in the Tri-Cities area of Harlan County, Kentucky. For them, while the white and black social worlds may have been segregated, and whiteness was somehow a proxy for economic status, whites were by no means in a class of their own. The black community had its own culture, mores, traditions and celebration, and sources of pride. As their testimonies have shown in all their variety, that's just the way it was back home. However no black person in America escapes the veil of the color line. We all have our moment...

\section{Second Sight and the Emergence of Racial Consciousness}

There is a moment in every black person's life when they discover what their blackness means to the world. This is not a discovery of phenotype, but of history. It is the moment of awakening when he or she realizes that their blackness signals an accumulation of processes of racialization, a moment when the encounter of 1492 and the present collapses on his or her black body. This moment inaugurates the emergence of one's racial consciousness. Different from the taken-for-granted acceptance of racial segregation, iconography, discursive formations, etc., or feeling gratefulness that the Lord blessed us with fast legs with which to run from viscous dogs, racial consciousness gives the racialized subject the ability to see the injustice of it all. Du Bois (1903) called this second-sight—a "gift" that affords the racialized subject the opportunity "suspend 
the optics of the veil and see other possibilities of organizing the world." (Brown and Itzigsohn 2015) Du Bois animates the concept of second-sight in his allegorical essay, "Of the Coming of John", in Souls where he tells the story of John; a young black man who grew up in the rural Southern town of Altamaha, GA. Like the children in the TriCities area of Harlan County, Kentucky, John grew up happy and unaware of violent structure that Jim Crow was imposing on his body and mind. However, after leaving his hometown for college, John's second sight comes upon him in a transformative way. Du Bois (1903) writes:

Thus he grew in body and soul, and with him his clothes seemed to grow and arrange themselves; coat sleeves got longer, cuffs appeared, and collars got less soiled. Now and then his boots shone, and a new dignity crept into his walk. And we who saw daily a new thoughtfulness growing in his eyes began to expect something of this plodding boy. Thus he passed out of the preparatory school into college, and we who watched him felt four more years of change, which almost transformed the tall, grave man who bowed to us commencement morning. He had left his queer thought-world and come back to a world of motion and men. He looked now for the first time sharply about him, and wondered how he had seen so little before. He grew slowly to feel almost for the first time the Veil that lay between him and the white world; he first noticed now the oppression that had not seemed oppression before, differences that erstwhile seemed natural, restraints and slights that in his boyhood days had gone unnoticed or been greeted with a laugh. He felt angry now when men did not call him Mister, he clenched his hands at the "Jim Crow" cars, and chafed at the color-line that hemmed in him and his. (Du Bois 1903, p. 149).

Like John, several participants cited their first encounters with new cities and communities as the first time that they "saw" race. In part because the onus was on them to pick up on the "thousand and one little things" that made up the social fabric of a new surrounding, including the racial etiquettes and orders; thus making them conscious of the labor that came along with performing their race. Travel also sparked this awakening because the contrast of racial landscapes gave them new set of criteria with which to 
evaluate their own home setting. Speaking of his own racial awakening William Jackson recalls,

That is interesting because, early on I didn't even - that was no big deal to me, I didn't know anything about blacks and whites separating, this is the way of life. This is how we lived and it was fine, but I think as time went on, you started becoming aware because you got older. For the summer you might go to Chicago or New Jersey or somewhere, and then you would pick up little things about race relations, then you would come back to Lynch. Then you start thinking like, "why don't black people live in Main Street? We all live over here"; so I think as I got older, I became aware of a lot of stuff. I do not to this day remember anybody ever in Lynch calling me a nigger, I do not remember that.

--William Jackson | Born 1945 in Lynch, | Resides in Los Angeles, CA

Du Bois wrote of his own racial awakening when, as a young child, a little white girl refused his offering of a decorative card during a group game. Her refusal was subtle at best, but he recognized it beyond a shadow of a doubt that her refusal, along with her particular look of contempt and disdain, was due to his race. From that moment on, he went from not noticing race to seeing it everywhere. Of this encounter Du Bois (1903) wrote, "then it dawned on me with a certain suddenness that I was different from the others; or like, mayhap, in heart and life and longing, but shut out from their world by a vast veil." This last section of the chapter attends to how that sudden moment is experienced in all of its force and subtlety.

Again like I said we lived on Church Street. And I used to play with the Miller brothers. So what happened was the family next door to the Millers, they moved, and this other family moved in there. So one day I was going down, and I was looking for Jim. So I went in the yard and all I heard was a voice say. "What are you doing down here?! Get'on back up there where you belong?!" And I'm going like [to himself] "Who said that?" So I stopped. And he said again 
"Didn't you hear what I said? Get'on back up there where you belong!" So again I didn't move. I'd never heard that before. I'd gone on down and knocked on Jim's door a bunch of times before. So this guy comes out the house. A grown man. "You better get your so-and-so out the street! I'm talking to you!!" But there was a guy, a neighbor of my parents heard this guy, and he came out and said "I know one gotdamn thing, you better not touch him!" So the guy went back in the house. So I left...And so, that was it. That was my first experience. I was in elementary school. That's what got me, I just remember hearing that voice - "You better get back up there!" And I froze... What got me was, now that I think about is that I froze. And I still ask myself why did I freeze? Personally, that was my awakening.

--Victor Prinkleton | Born in 1944 in Lynch, | Resides in Lexington,

Why did Victor Prinkleton freeze? What did his subconscious mind know that he did not at that moment in time, and why did his body respond by entering into a temporary state of paralysis? Is there such a thing as a racial atavism, where the specters of racial violence visit upon black children's consciousness to remind them of what lay behind that man's "What are you doing down here?!"-was it the ghost of "Hey, Nigger's" past? While we can only speculate why he knew to freeze, we can see traces of how this second-sight continued to map Prinkleton's social world, as it did for other black boys and girls in his community. Again he returns us to the site of the yard:

And some of that stuff you just picked up on, ain't nobody had to tell you. I'll never forget once when I-there were two sisters that lived behind us - their grandmother used to talk to my mother all the time. And she would keep these girls and they had to move in temporarily. And I used to take a shortcut, I used to go to the creek; and I had a habit of cutting through this yard to get over to Looney Creek. And these girls one day, they were out there in the yard. And as usual I started going out through the yard and something told me, [he says to himself] "oh...there's Pat and Martha." Right away the light goes off,-- "don't cut through the yard, Pat and Martha are out there." I guess I was about fourteen or fifteen. And, so I just, took the long way around. Cause I knew. There's some things people ain't got to tell you. You just knew as a young black.

--Victor Prinkleton | Born in 1944 in Lynch, | Resides in Lexington, 
However second-sight does not provide a escape from the reality of the sheer and utter violence of the veil. It grants consciousness, a knowing awareness of what is really determining the scene, however it does not provide the tools to break down, jump over, or transcend the wall of the veil. Beyond anything else, it is a tool of survival; mental and physical. Yet and still, the cries of these black children went unanswered.

...we wondered that and said "why?", but we could not get an answer at the time. You know our parents could not give us a good answer to "why do we have to be here and they're there, and they got quality things that we don't have?"...And we knew one thing "why?"- because of the color of our skin. (Sanford Baskin $\mid$ Lynch)... and why are we treated so mean? But God never did answer me you know? And that was the question that I just wanted the answer to...(Ernest Pettygrue)

\section{Conclusion}

On the surface the racial landscape that this second generation grew up in in Kentucky seemed different than that of their parents, however the structure was the same. The difference was the way in which race relations in the Tri Cities area was performed; the politeness and the knowing ones place. As long as the terms of the old racial contract were maintained, there was no reason for exerting outwardly repressive measures to maintain order. Instead the ideology of white supremacy and the structure of separate and unequal were internalized into the habitus of all living in the Jim Crow South. As long as

they had internalized these overt structures there was no longer a need for signs and lynchings, all people knew their place. However the veil of the color line would expose itself in moments where the racial contract was breached, and in others to reinforce its durability. Forbidden acts such as miscegenation were cause for the force of the veil 
shine bright, while other instances of unambiguous racism ignited simply to reinforce the racial order, such as loosing viscous dogs on neighborhood children. While there is a general consensus that the racism in Kentucky was much better than that experienced in the Deep South—_it's not like we were in Alabama or Mississippi.” This was what racial progress looked like on the ground in the Jim Crow South. 


\section{Scene II}

\section{From Negro to African American: Race and the U.S. Public School System}

Black and white children were socialized into their racial selves at a very early age, and as the previous chapter revealed, these processes of racialization were enforced through an assemblage of institutions, ideologies, class structures, mores, laws, and geographies. The pathway to the formation of the racial self was not a straightforward one. However, nowhere did these assembleges intersect with one another more than in the school. The following scene takes us to the school system in the Tri Cities area, from the era of the "colored school" system through the moment of desegregation. Herein lies the most ethnographically rich site of transformation for $20^{\text {th }}$ century African American subjectivity.

Over ninety percent of the participants in this study matriculated through one of the "colored" schools in Harlan County, during their childhood, with half of the sample attending a segregated school for his or her entire 1-12 grade education. The following chapters trace two periods in the history of race and education in America: the era of de jure black segregated education and the moment of school desegregation in Harlan County, . I show the ways in which black subjectivity was formed and transformed through this period of major structural transformation.

Chapter Four, "The Colored School" takes up the institution of the colored school as a distinct cultural formation and examines the structure, pedagogical philosophies, and institutional logics that undergirded these racially segregated Southern institutions, while 
Chapter Five, "The Hidden Injuries of School Desegregation", takes up the process of school desegregation from the perspective of the African American children of integration who experienced the transformation. Between these two chapters, I show the ways in which this generation recalibrated their subjectivities in response to their changing landscapes of meaning. 


\section{CHAPTER FOUR}

\section{The Colored School}

\section{Introduction}

There was a time in this country when many States enforced the legal segregation of schools for black and white children. Resources for public education were allocated strictly along racial lines, where white schools received multiple times the dollars-perstudent, infrastructure, faculty, curriculum, and attention from the State, while black schools were left to the capricious whim of the local Board of Education. The postbellum apotheoses of what Omi and Winant (2014) call a "racial project", colored schools once populated the Southern and Border States of the country. These separate and unequal institutions were one of the quintessential racial formations of the Jim Crow South, embodying institutional logics of white supremacy and materially representing the racial order of things. For nearly a century after the abolition of slavery, African American children were subjugated to these structurally inferior schools. Then, in 1954, after countless attempts to adjudicate the constitutionality of the "separate but equal" doctrine affirmed by Plessy vs. Ferguson in 1896, the United States Supreme Court decided on Brown vs. Board of Education - shattering the logic that an institution that was separate could be equal, at least in the context of public education.

While the following chapter takes up the impact of Brown on the generation African American children who integrated the public schools in Harlan County, , this chapter focuses on the "colored" school itself. It is rare to see the remnants of these 
separate and unequal institutions anywhere in our country. Shortly after the Brown v. Board decision, local school boards raced to change the names of local "colored schools" to detract attention from the fact of their existence; for example in Harlan County the Lynch Colored Public School (LCPS) was renamed "West Main High" in 1956, to make the racial project invisible for the passerby. Once school systems finally did desegregate, common practice closed down the black school, as the buildings were far too raggedy for the community's white children to attend, and to send the black children to the white school. For this reason, there are very few colored school buildings that still stand in their original state throughout the country. In Kentucky, there are two — one in Lexington and the Lynch Colored Public School. In the revelry of the victory of Brown, and the quiet closure of this ugly period in our nation's history, we have allowed ourselves to forget the colored school. While there is a plethora of literature addressing the social, economic, and political consequences of Brown and its legacy, there is much less said on the American colored school. What was the colored school as a cultural and institutional formation? What was its relationship to the racial self?

Assuming that the goals of the State and that of the masses of newly freed slaves were set on opposite sides of the veil, two question arise: With the dissolution of the institution of chattel slavery and the emergence of the New South economy, what type of subject did the institution of the segregated black school intend to interpellate? And, what cultural form emerged within the black community within the constraints of this state imposed post-bellum "racial project"?

\section{The Moral Education of the Negro in America}


In his lecture series Moral Education: A Study in the Theory and Application of the Sociology of Education (2012) [1902-1903]) and Education and Sociology (1956)[1902-1911], Emile Durkheim situates the primary function education as cultural transmission. For him, education is the "action exercised by the older generations on those not yet ready for social life. Its object is to awaken in the child those physical, intellectual, and moral states which are required of him both by his society as a whole, and by the milieu for which he is specially destined" (Durkheim, 1956, p. 71). In this formulation, education serves both a practical and moral end; one that, as French structuralist Louis Althusser (1971) argues, "interpellates" certain types of subjects, ones who are fashioned to serve differential needs of the individual and society.

Durkheim's meditation on the role of the school was aimed towards a pressing social issue facing his country at the turn of the $20^{\text {th }}$ century: in this moment of nationalism, secularization, and the making of "Frenchness", what could the state do to produce a generation of unified French citizens? This was a question of subject formation. For him, and other French thinkers, there is no institution more influential than the school. Similar ideas about the moral function of the school are woven into American ideals as well. In the Brown Supreme Court ruling, Chief Justice Warren reminds the Court that "today, education is perhaps the most important function of state and local governments", and that "it is the very foundation of good citizenship. Today it is a principle instrument in awakening the child to cultural values, in preparing him for later professional training, and in helping him to adjust normally to his environment." With the colored school system emerging in the Reconstruction era of the 1860s and proliferating itself throughout the U.S. South for almost one hundred years, up until the mid-1950s, it is not 
a stretch to argue that to know about black subjecthood in America, we must know about what "cultural values" the colored school "awakened" in the hearts and minds of the black child. In other words, how did separate schooling in the South contribute to the formation of a specifically black child?

The colored school was a dual system, with an institutional double consciousness of its own, as it only existed as an ascriptive second-order formation in relation to the white school. Established and indirectly managed by local white boards of education, the colored school was no doubt an ideological state apparatus in the Althusserian sense. However it was also a private site of black cultural expression, as black schools were wholly operated through the close-knit cooperation of black administration, teachers, and parents. The function of the colored school in the state's imagination was obvious - to create a subpopulation of docile bodies to labor in the underbelly of the American occupational structure, to inculcate notions of black inferiority and white supremacy within the black and white races of children - lessons they would hopefully carry with them for the rest of their lives - , and to reify understandings of ontological racial difference and misrecognition (J. D. Anderson, 1988). However, beyond the state, the moral function of the colored school was also up for debate within the black community.

\section{To Make Men Carpenters, or to Make Carpenters Men?}

Although most remembered by the trenchant battle between W.E.B. Du Bois and Booker T. Washington, the debate over the best educational needs of black children can be traced back to the post-emancipation moment of the 1860 s with the launch of the Hampton model, a pedagogical philosophy that imposed industrial education on black 
children. Proponents of the Hampton Model argued that America's formerly enslaved population needed an education that would prepare them to assume their rightful position at the lowest rungs of the segmented labor market—as domestic servants, factory workers, millners, porters, and any other job deemed unsuitable to whites. Hampton model advocates deemed components of the classical curriculum, such as literature, language, and the sciences, as superfluous, and some even believed that introducing such areas of thought to the Negro mind would be harmful, as their was no need to encourage black children to dream of a world that would never be theirs. In this view, the Negro in America needed to be trained to do, not to think. James Anderson's (1988) "The Education of Blacks in the South, 1860-1935", illustrates how the Hampton model gained tremendous support not only from white Southern functionaries, but also from influential Northern philanthropists such as Julius Rosenwald, Woodrow Wilson, and Andrew Carnegie. A minority of black leaders also championed the industrial education model, with Booker T. Washington as the poster-child. Of industrial education, in his 1900 essay Afro-American Education, Washington writes:

"The educational work in the Southern states is accomplishing wonders in the moral and intellectual uplift of the people, which has already benefitted in the life of the South, and must be felt in larger measure in years to come. There has been a marked tendency of late years to make the education conform more to the industrial lines laid by General Armstrong. This is a healthy sign, as the more practical education is the better, especially as the tendency of modern industrialism is more and more towards specialization in all departments of learning and acidity of whatever sort; and this is said without intending in the least to depreciate or underrate what is regarded as the higher education. All education is good, but assuredly that is the best which enables a man to fit in most readily with the conditions of life in which he finds himself."

Washington purported that the most practical pathway to incorporation into American 
society was through a bottom up approach, through which blacks in American would willfully assume their position at the bottom strata of the labor economy and eventually gain the right to full citizenship — formal and social—-through thrift, obedience and hard work. For Washington, industrial education was the foundation upon which African Americans would build their ethos. In another speech, he claims:

"On such a foundation as this will grow habits of thrift, a love of work, economy, ownership of property, bank accounts. Out of it in the future will grow practical education, professional education, positions of public responsibility. Out of it will grow moral and religious strength. Out of it will grow wealth from which alone can come leisure and the opportunity for the enjoyment of literature and the fine arts."

The opposing argument was that black children needed a liberal education; one that would produce mechanics, factory workers, and housemaids, but also lawyers, doctors and men and women of letters. According to Washington's black contemporaries, such as Anna Julia Cooper and W.E.B. Du Bois, accepting a solely industrial education was unduly stifling, claiming that it "practically accepts the alleged inferiority of the Negro races". Even some Northern missionary societies balked at the notion of industrial education, particularly the ideological Hampton Model, claiming that it "undermined the democratic rights of blacks by assuming that black students were destined for a subordinate industrial role in the southern economy" (Anderson 1988). Du Bois however did not wholly condemn industrial education, he instead argued against setting it as the sole pathway for black educational attainment:

"I am an earnest advocate of manual training and trade teaching for Black boys, and for White boys, too. I believe that next to the founding of Negro colleges the most valuable addition to Negro education since the war, has been industrial training for Black boys. Nevertheless, I insist that the object of all true 
education is not to make men carpenters, it is to make carpenters men; there are two means of making the carpenter a man, each equally important: the first is to give the group and community in which he works, liberally trained teachers and leaders to teach him and his family what life means; the second is to give him sufficient intelligence and technical skill to make him an efficient workman..."

The majority of the black intelligentsia and a handful of white educational entrepreneurs stood firmly on this side of the line. However, the Hampton model was mobilized more forcefully throughout the South than the classical model due to the vast financial support from it received from Northern philanthropists - those industrial barons who had a vested interest in controlling the American labor supply.

These two "warring ideals" were metabolized into the structures of the black educational system at all levels, as the majority of black teachers were educated at black colleges--primarily founded by White philanthropists such as John D. Rockefeller--from which they went on to teach at black elementary and high schools. These colleges were built on explicit ideological principles. For example, Hampton and Tuskegee were the exemplar of the Hampton model. While other colleges, such as Morehouse, Fisk, and Wilberforce were founded under the auspices of the liberal classical model. The black teachers who were sent out to teach black children in the South embodied these logics. If this national discourse interpellated a particular class of teachers, how did these competing logics reverberate through the colored schools? Stated differently, how did these competing discourses play out in the everyday lives of the students who matriculated through this system? Giving particular focus to the period leading up to school desegregation, what type of subject did they aspire to create? 


\section{The History of Education in Eastern Kentucky}

Like most southern states, public education in Kentucky was legally segregated by race. Section 4363-8 of the Kentucky Statutes reads:

"It shall be unlawful for any white persons to attend any school or institution where Negroes are received as pupils or receive instruction and it shall be unlawful for any Negro or colored person to attend any school or institution where white persons are received as pupils or receive instruction or school; provided, the provisions of this law shall not apply to any penal institution or house of reform."

District Boards' of Education were responsible for furnishing and maintaining public schools that offered $1^{\text {st }}-12^{\text {th }}$ grade education for their given territory; however it was not until 1936 that the Statutes were amended to explicitly mandate a full $12^{\text {th }}$ grade education for non-white children.

Given the mountainous, sparsely populated, underdeveloped condition of the Appalachian region of Kentucky, William T. Gilbert (1948) wrote, "maintenance of twelve grades of school service for Negro children in districts where the Negro population is sparse has become a serious problem in eastern Kentucky." At the time, high school enrollments ranged from "six pupils in Pineville High School to 288 pupils in the Lynch High School."

A Tale of Two Schools in Harlan County USA

Owned and operated by International Harvester Corporation and United States Steel Corporation respectively, Benham and Lynch were two of the most prodigious coal 
mining towns in all of Central Appalachia (Caudill, 1962; Lewis, 1987). Separated by a shared baseball park, these neighboring coal-towns were in fierce competition for labor, and both took up the strategy of building more attractive "model towns" to develop a stable workforce. Each town had to offer comparable living standards to retain laborers. For example, in a 1917 company correspondence to Benham mine superintendent about their forthcoming corporate neighbor, International Harvester company president, H.F. Perkins writes about upcoming developments by United States Steel, "they want a graded school for their colored people and a graded school for the Americans and a high school for the Americans" (Wisconson Steel Corporation: 1917). This is the condition under which the colored schools in the towns of Benham and Lynch Kentucky came into existence — one school for the 'colored people' and another for the 'Americans'.

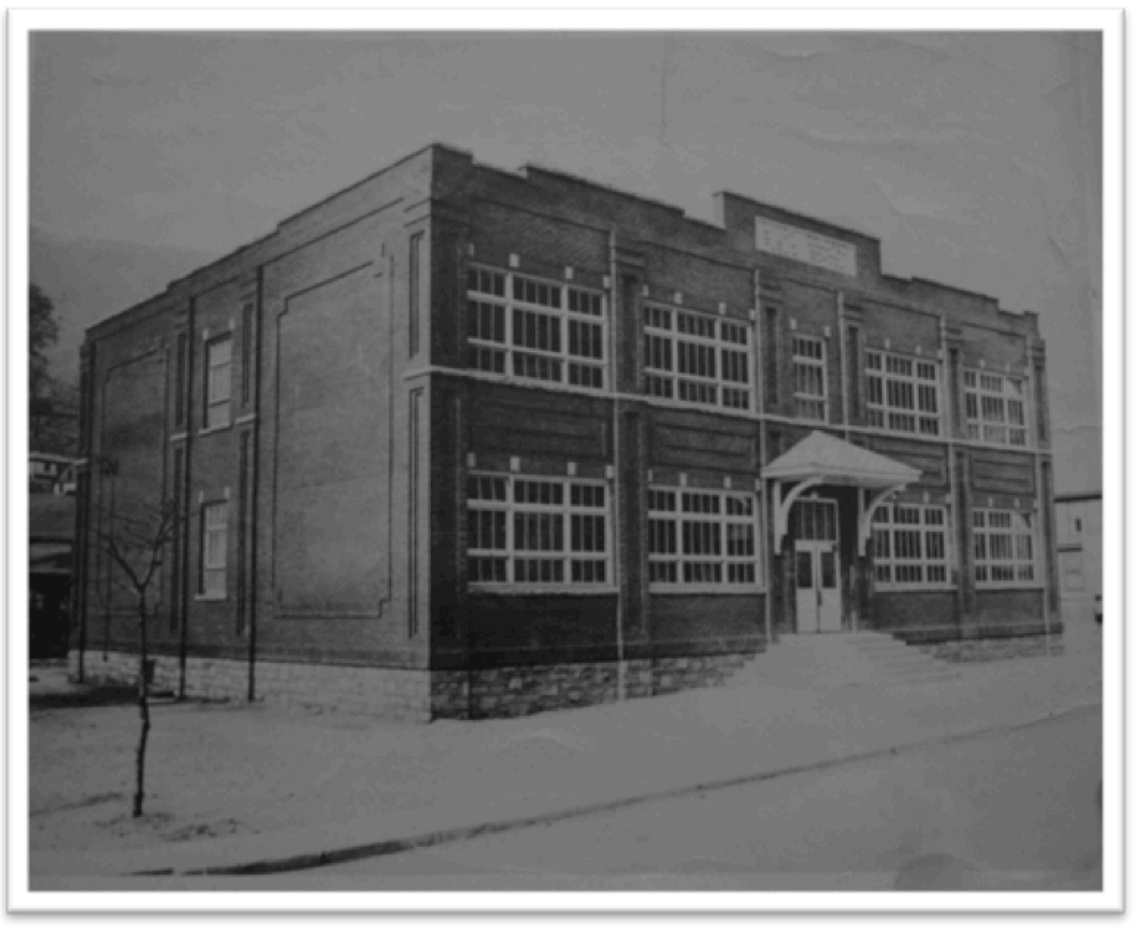

[Figure 23. The Lynch Colored Public School | circa 1940] 
Lynch Colored Public High School opened its doors in the fall of 1923 and, within a year, the Benham Colored Public High School opened as well. Although there was some disparity in the size, enrollment, and faculty salary scales between these two schools, Lynch and Benham Colored Schools were considered the finest in the region. Both high schools graduated over four decades of black coalminers' sons and daughters.

All of the teachers at Benham and Lynch came with at least a bachelors degree, and several went on to continue at the maters-level during their tenure in the colored school system. Former teacher Rosie Ivory Pettygrue remembered how impressed she was with the caliber of teachers at Lynch Colored School when she arrived in 195X,

...because they had a better high school than we did in my hometown. And they had really qualified teachers.... lot of their teachers already had masters degrees. I know Miss Knight did, Miss Gregory did. But they all had degrees and see and in the county, there were some county teachers teaching there with just two years of college.

--Rosie Ivory Pettygrue | Born 1937 in Greenburg, | Graduated Kentucky State College ' 57 | Former teacher at the Lynch Colored Public School

Apart of the company's social engineering project, the company's deputized its black principals—Professor Matthews (Benham), Professor Shobe (Lynch) and his successor, Professor Coleman (Lynch) - to go out to colleges throughout the Southern and Midwestern regions to recruit the top performing black graduates to come and teach up in the hills of Appalachia. As a result, the black principle had tremendous license to hand pick his teaching staff in-line with his own vision of what the flavor and texture of pedagogy and teaching profile that he so desired for his school. Although the schools were segregated, the companies strove to create a "model town", offering resources, salaries, and amenities that were superior to their neighboring competitors in the Central 
Appalachian region.

Armed with the authority to make hiring decisions and to offer teaching salaries that were often more competitive than the going rate in major cities, the black principles at the colored schools at Benham and Lynch recruited what they considered the best of the best. An unusual destination with a dearth of college educated teachers in the region-black or white - teachers at the Benham and Lynch Colored Schools primarily got their jobs solely through principals' personal or alumni networks. One of the former teachers, Mrs. Rosie Ivory Pettygrue, recalls her excitement about being recruited by Professor Coleman during his visit to Kentucky State:

And so I never really had an interview, I never wrote a resume for job. And so what happened, Mr. and Mrs. Coleman came by and it was in the summer and that was before you could not go to a restaurant and eat. You didn't go to a hotel and stay so they just came to our house and my father worked in Louisville at the country club in the summer time. And so my mother was not at home when they stopped by and I had just finished Kentucky State....and also, I had a job offer in Lexington and Elizabethtown. And then when Mr. Coleman told me what I'd be making in Lynch, it was going to be more than what Elizabethtown or Lexington paid! Because Lynch was independent. It was not a county school. So buddy I got busy. I killed a chicken, I picked the chicken, I cut the chicken up, I fried the chicken, I mashed potatoes, I made a salad. I did all this to fix him dinner. And he was so impressed!

Lynch ran an independent school system, U.S. Steel paid teachers handsomely instead of subjecting them to county rates. This was partly because of the company's desire to create a model community, and partly because it had to incentivize professionals, such as teachers, physicians, attorneys, and engineers, etc., to move to the isolated mountain region of Kentucky, rather than them pursue opportunities in nearby urban centers such as Lexington, Louisville, and Frankfort. Another teacher, Mrs. Vergie Mason recalls going to Lynch after graduating in 1941 from Wilberforce University in 
Ohio. She too was recruited through the John V. Coleman grapevine:

My sister was a teacher and her principal knew the principal of Lynch [Mr. Coleman]; he told my sister and that's when I applied for the job. I went up for an interview. I didn't know where Lynch was. I went up for an interview and thought, "I don't want these mountains. I don't want this job. I hope they don't call me"...but after I got there I realized it was a lovely place".

Even those teachers who did not have a direct personal connection with the principal, were recruited based off of their affiliation with the principals' alma mater. Both graduates of the Commonwealth's black college, Kentucky State, the lion's share of the teachers in the Tri-Cities area were also K-State graduates. Charles Price was one such recruit. A native of Louisville, and Kentucky State graduate, Mr. Price had his eye set on migrating to Chicago to join his family and friends who had previous journeyed to the Midwest in search of better opportunities. Poor and out of the black elite network, Charles understood that he would have to cast his own lot in life, and planned to start off as a substitute teacher for the Chicago public school system until he could find a permanent position. That is, until Mr. Matthews called:

Yes, I was not of the system. But and that's how I ended up in the mountains of Kentucky because they offered me a job. I did not apply for a job but I was offered a job in Benham. I was on my way to Chicago and I was going to go to Chicago and substitute until I could find a permanent job, but I was offered--I was called by Jay Matthews and he said "I need a music teacher and I heard that you were available, would you come?" I have no idea how he found out about me...his connection with where I went to college I guess.

--Charles E. Price | Born 1933 in Louisville, | Graduated Kentucky State University ' $5 \mathrm{X} \mid$ Former teacher and last sitting principal of Benham Colored School

Teachers such as Mrs. Mason, Mrs. Ellison, Mrs. Sweatt, Mr. Price, and Mrs. 
Knight to name a few stayed at the colored schools in Benham and Lynch for over thirty years; long enough to teach two generations of black children in Lynch, Kentucky. They came from the leading historically black colleges and universities (HBCUs) in the South and Midwest—Wilberforce University, Hampton College, Tuskegee University, Tennessee State College, and of course, Kentucky State College. As the previous section illuminates, these institutions mattered in terms of the type of training and ideology the college supported. For example, although now a liberal arts university, Kentucky State College was originally founded in 1886 as the State Normal School for Colored Persons. K-State was established under the auspices of the Hampton model with the mission of training black teachers for black schools. The college's ethos of industrious work ethic, rote learning, and black respectability emanated from the teachers and largely shaped the school context in the Benham and Lynch Colored Schools. Before we go to these specific schools, it is important to expand upon the figure of the pre-Brown v. Board black teacher and the black principle in a historical broader context.

\section{The Black Teacher}

\section{The Choosing and the Chosen Ones}

The black teacher embodied the ideology of racial uplift (Fairclough, 2009; V. S. Walker, 1996). They were like missionaries sent out to the rural hamlets of the South to educate the black masses, to expel impulse and instill within their souls a spirit of thrift and providence, and to awaken the benighted young negro to the ways of the world. In the early decades of the $20^{\text {th }}$ century, most HBCUs pressed their students to become teachers, both because the black masses were in dire need of basic education and because 
the veil of the color line occluded blacks from most professions in the American

occupational structure. Whether the young gifted and black desired to be engineers, accountants, or concert pianists when they entered college, a teacher they would be by the time they graduated.

Even W.E.B. Du Bois was influenced by this steering during his time at Fisk University in Nashville, Tennessee, where students were encouraged by the faculty to go out during their vacation months and find a country school at which they could enlighten the black masses. Reflecting on that time in his life in the essay "Of the Meaning of Progress" in Souls Du Bois (1903) recalls:

"Once upon a time I taught school in the hills of Tennessee, where the broad dark vale of the Mississippi begins to roll and crumple to greet the Alleghenies. I was a Fisk student then, and all Fisk men thought that Tennessee-beyond the Veil - was theirs alone, and in vacation time they sallied forth in lusty bands to meet the county school-commissioners. Young and happy, I too went...”

Reveling in his memories of the "hunt" for a Tennessee country school in need of a teacher, Du Bois relays:

“...I learn from hearsay that the hunting of ducks and bears and men is wonderfully interesting, but I am sure that the man who has never hunted a country school has something to learn of the pleasures of the chase. I see now the white, hot roads and fall and wind before me under the burning July sun; I feel the deep weariness of heart and limb as ten, eight, six miles stretch relentlessly ahead; I feel my heart sink heavily as I hear again and again, "Got a teacher? Yes." So I walked on and on..."

This generation of educated Negroes - the men and women of Fisk and Hampton and Kentucky State and Wilberforce and Spelman and Morehouse — were groomed to be the "talented tenth", the best that black society had to offer the world. However, they were trained that their position in the upper crust of the veil came with an almost divine responsibility — to lift up their fellow soul mates who occupied the lowly status of the 
"black masses" out of poverty, illiteracy, and strife so that the negro could assume her rightful place at the center of American life. It is for this reason, for the many black graduates who embraced this mantle, that these educated young men and women did not mind relocating to small rural towns, distant from all of the action of city life, to assume their calling as teachers in the Jim Crow South.

Even those who set their sights on other aspirations were steered by their institutions to pursue teaching. Former teacher at the Lynch Colored Public School, Vergie Mason was one such person:

Actually I didn't want to become a teacher; I really wanted to be a secretary. I worked in the office in the high school just doing things in the office and I liked it; and wanted to go to college to be a secretary. But after getting to college and I took so many secretary courses, my counselor called us and the others that were aspiring secretaries to take five educational courses so that we would be able to teach, because they were not hiring a lot of black secretaries. And so I took the five extra courses and then I graduated - I tried to get a secretary job but they were not hiring. So they needed a business teacher and I thought I would just augment business education in Lynch Kentucky.

Preceding the wholesale integration of higher education institutions, the majority of college educated African Americans attended historically black colleges, where choices were limited in terms of degree concentration. Even the few who did earn degrees from predominantly white institutions were shut out of the elite labor economy and channeled back to black schools in the South to uplift their race (J. D. Anderson, 1988; Fairclough, 2009). These recalibrations of dreams and aspirations were common for young black college students of Vergie's generation. Three regimes of domination were influencing her choices at the time; the veil of the color line that was always already determining the life outcomes of black folks, the patriarchal labor market that delineated men and women's work, and the institution - the HBCU—whose mission was to produce 
black teachers for black students. In the end, she resolved herself to make the best of her situation; if she could not be a secretary like she had dreamed, she would sure enough "augment business education in Lynch, Kentucky."

\section{A Class of their Own}

Preachers and teachers were often the only members of the rural black community occupying a middle class status, and were exalted by black parents and children alike, as they held the key to unlock opportunity's door. However Jim Crow saw to it that their social capital as educated middle class Negroes did not translate into access to the broader economic, political or social spheres of society. In this way, black educators in the early $20^{\text {th }}$ century occupied, what historian Adam Fairclough (2009) refers to as, " $a$ class of their own".

They lived behind the veil, in the segregated community amongst the children and parents to whom they felt responsible; taking leadership roles in church and community, socially interacting with parents and friends, and living their everyday lives within the black social world. The black community trusted their black teachers and depended on them to be leaders in and outside the classroom. In her role as a

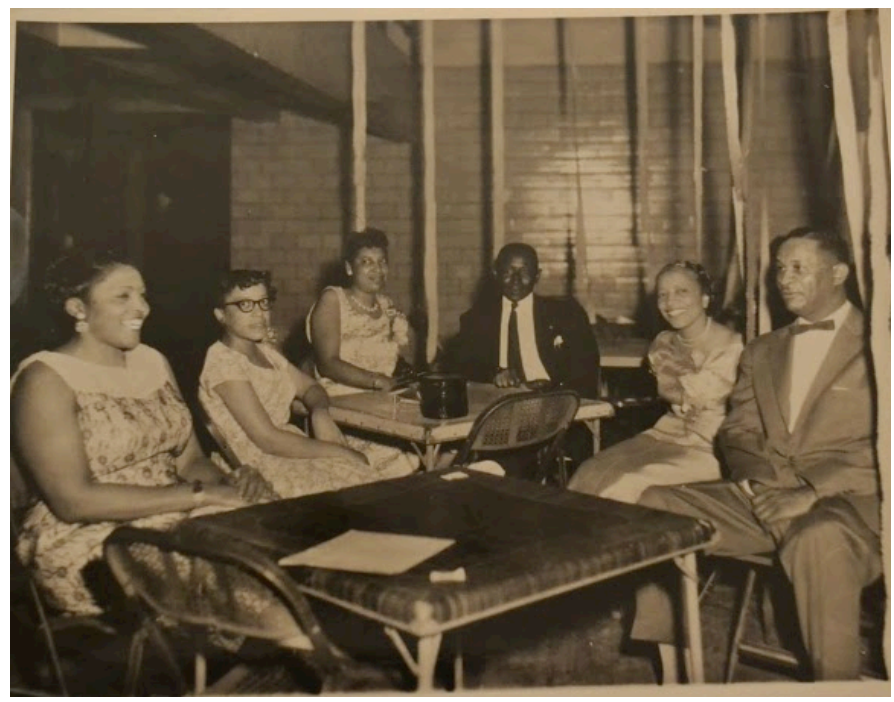
teacher in Lynch, Vergie 
Mason remembers this mantle all too well:

They expected it. Back then teachers were looked up to and they were sort of leaders. People looked up to us; the parents all looked up to teachers and so you had to discipline yourself so that you can set a good example for the children. And so we went to church - yes, and whatever it was to be done that they wanted the teacher represented if they would call on them. And we were at different - all of the activities at school, we sold tickets, we chaperone and we just did everything at school for the kids and they expected it. And we had fun doing it.

With this expectation came a heightened sense of awareness in teachers of their own social position within the community. As a result, teachers had a reputation of being omnipresent, caring, and intimately involved in the lives of the black families in the community, while at the same time somewhat removed and even aloof. However in tiny close-knit segregated communities like Benham and Lynch, lines between the personal and professional were always subject to be blurred.

And I remember Mr. Matthews who was our high school Principal; he deterred me from dropping out of school. This is the way our teachers taught us; he said, "I want you to be the first one to graduate" and I will never forget that. He called me into his office before graduation. But I don't know - you are too young - but he preached to us all the time; our instructors did and took a personal interest. Integration is coming, you can't be just as good, and you have to be better. And they really took their time; sometimes I could come home from school and one of my teachers might be sitting at the table eating. We shopped at the same stores, went to the same church, everything.

--Harriett Calloway Hillie | Benham Colored School | Class of 1960 


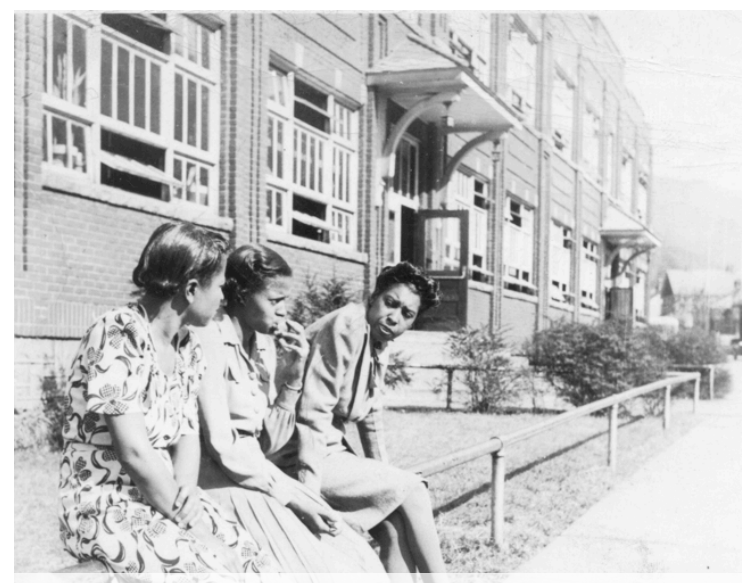

Figure 25. Ms. Mady Knight (teacher) at sitting with two students in front of the Lynch Colored Public School | circa. 1940
The teachers talked to the students, disciplined them if they saw them misbehaving in the street, sent them on little errands like going into Cumberland to pay a bill or to pick up a sundry from the store. They invited the children into their homes, and visited with the families in the community, gave rides, patched up scratches with gauze and Band-Aids, looked them in the eyes

and greeted them with a smile. The teachers, the parents, and the children belonged to each other.

'Fess

Inculcated with the principles of self-help, thrift, industrial labor, and rote learning, the black teacher embodied a particular habitus that was then reproduced within local black schools throughout the country, particularly in the South. This particular mode of black pedagogy was perpetuated by the black principal—universally referred to in the South as Professor, or 'Fess, by the black community—who acted as the broker between the white power structure of the local board of education and the inner-workings, pedagogy, and mode of black learning that the black teacher was to adopt (V. S. Walker, 2009; V. S. Walker \& Byas, 2003). Fess was responsible for maintaining order within the colored school, he was responsible for recruiting qualified black teachers, managing their teaching style, vying for additional resources and expanded curricula from the white school board, and placing students at colleges. 
I remember Mr. Coleman especially when it - when my senior year he was very instrumental in seeing that I got to college. And then I think the first year after I completed that year he was principal over here at the high school and I worked in the office with him and he had me typing letters to schools concerning getting other students and into college.

--Clara Clements | Lynch Colored School | Class of 1955

Both colleagues and students remember the principals as being no nonsense

disciplinarians. Principals were at the top of the food chain in the black community, and they commanded respect from everyone.

Professor Matthews, oh my God! He was one that you just didn't cross. He always chewed his tongue for some reason, I didn't know why. But you knew not to act up or he would paddle you.

--Virginia Ward | Benham Colored School | Class of 196X

Called him 'Fess' that's what they called him. You know I have seen him do a little thumping and paddling but I got different experience you know...He was he was a disciplinarian. He commanded respect from the teachers and from the students.

--Charles E. Price | Born 1933 in Louisville, | Graduated Kentucky State University '55 | Former teacher and Mr. Matthew's successor as the last principal of Benham Colored School

Principals and teachers were often active participants in regional and national black professional organizations, such as the Kentucky Negro Education Association (KNEA), that paralleled the white associations from which they were excluded. These organizations were subversive channels through which black faculty and administration disseminated information, organized strategies of resistance, and set the agenda for how 
best to educate their black children, irrespective of the unequal mandates that the white boards of education may have put forth (Walker, 2009). For example, the organizations set the standards for parental involvement in supporting school activities, incorporating "off the books" courses, such as Latin or literature, into the curricula, and even children's hygiene.

The segregated school system in the Tri-Cities area of Harlan County operated within this broader system. Both Benham and Lynch had their own "colored" schools, while the black children in Cumberland, in absence of a segregated school, attended the school in Benham. From 1923 to 1963, black children in this area spent their entire primary and secondary educational careers, from first through twelfth grades, in one school building, where the same black teachers who taught a student's elder siblings, and in some cases their parents, taught them. Teachers, students and parents shared a familiarity and intimacy that extended far beyond the classroom, and in this way, the "colored" schools in Benham and Lynch were as central to the black community in terms of cultural production as the family and the church.

\section{The Interiority of the Colored School}

So what was it like to attend a colored school? What seems like such a long time ago, is in fact recent history - an experience that is only one or two generations removed from our present day — to the extent that every individual in my study matriculated through the "colored" school system at some point in his or her 1-12 education ${ }^{14}$. In the segregated South, the family, the church and the school was the trifecta of the black

\footnotetext{
14 There was no kindergarten at the time.
} 
cultural production. In few other spaces could blacks escape the regulating gaze of white society. These were the spaces in which they collectively constructed the black social world, the place where they were their blackest. Therefore, before moving on to the analysis of the transformation from segregated to desegregated schools, the site of analysis the next chapter, it is apropos ground our inquiry in "the way it was", or at least the way they remember it being.

Well, we had the most fun school you could possibly ever imagine. We had some fabulous teachers, and they would really wear you out to make sure that you got what you were supposed to get. (Willie French) ... strong, strong disciplinarians. All of the teachers had their own ways. But you know discipline was all that they did there. And it was the same with the Janitor, anybody who was seen as a responsible adult was to be respected. That's just the way it was, you know. (PG Peeples) We had one beautiful time going to school there, of course schools were a lot stricter then than they are now and you were not told too many times what to do because if they had to tell you three or four times you caught it. (Odell Moss) And mother told us that if she had to come to school because of us, we were going to be automatically wrong until we could prove ourselves right. So we didn't want that to happen. (Raveryn Whit)

I think everybody who went through school with them teachers got a whooping. And they were saying, they wouldn't spare no rod, because they were saving the kid. That's what I thought about it. They wanted to make sure that everybody that they taught would have a very good education. Or had the basics to get that good education. Because they had been in college and they knew what they - what we were going to come up against when we got there. So they did a real good job of doing that. (Chuck Rodgers) We used to have some good times down at West-Main. Back then, the teachers cared, because they lived in the community and their main thing was to get you an education. And they would bust your rump back then. And Lord, I got my tail tore up! Miss Mabel Smith, I will never forget...before they tiled up the floor - they used to have wooden floors - and they would clean them, shine them up with oil, and I will never forget: Mom sent me into school, I had a pair of white pants on--and then you would break for lunch, you walk home for lunch and then you come back--when I went home for lunch, you could not tell what color of them pants was, because she had mopped that floor with me! But what she was trying to do was teach you; show you different things and I just was not ready - but we had some good teachers. (George Massey) 
They did not play, and you understood that, and that is the way it was. You accepted it and you moved on. As I look back on Miss Jackson, when you are in the classroom it's time to be serious, at noon you could play, when school is out you could play; in that classroom dot your I's, cross your T's, use proper language, sentence structure, that kind of stuff. (William Jackson) Yeah, no child was to be called dumb or be dumb. And if it took you staying in that lunchtime because you didn't get it, they

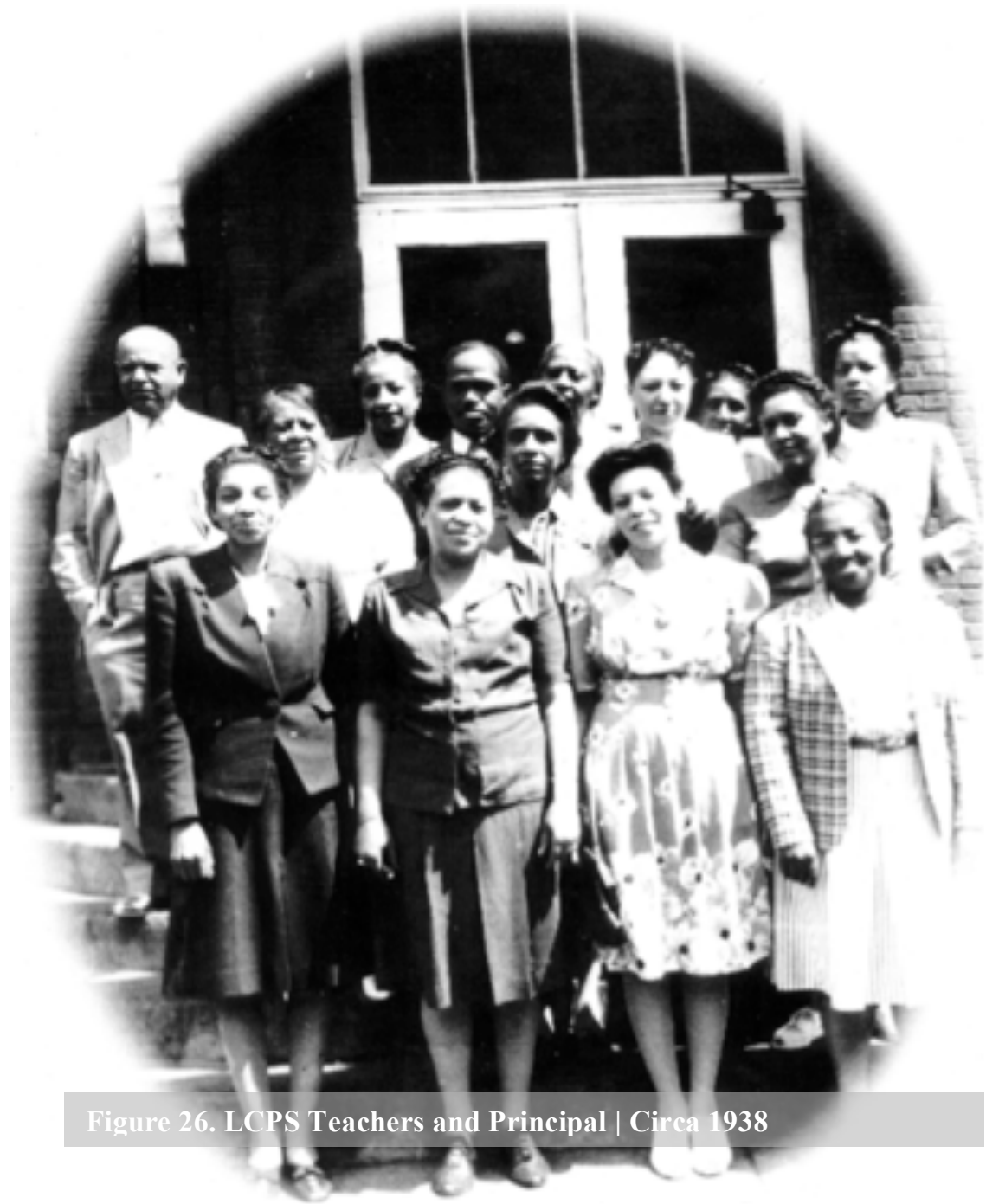
would keep you in there, you know. ...there was one time for me with fractions. I just could not get no sense of this fraction stuff. And Ms. Mason said, "Oh, honey, you can do it." So, I had stayed one day till 12 because I could not get my fractions. And so she came back and see said, "did you get it?", And I said, "no mam". And she said, "let me help you out", and she kind of gave me a little spanking, you know. Then she went over that problem again, and I got it. I really got it. And not only that, you can wake me up in the middle of the night and I could work fractions. Short ways, long ways, which ever! (Lena Jones).

And so - but now having said all of that; there's no substitute for teachers, in this case for us of color who believed in our capabilities or who saw the future and what we could bring to the future in teaching us in a serious mode and holding us accountable for our capacities to be able to learn whatever we sought to learn. (Jerome Ratchford) And the teachers were just exceptional because all of our teachers, you know, they were genuine teachers. Most of them had the label of being professors. There were no young 
teachers like you would say just graduated from college. All of these teachers had experience you know...And there was no such thing as parent-teacher meeting because after school it was nothing for you to see the principal come by your house because he's visiting with your grandfather or going hunting with your grandfather or your math teacher is a friend of your mom or whatever. (Albert Harris) To be honest, I think we had some of the best teachers around... Miss Smith, this one right there, she was my second grade teacher; and I enjoyed her. Because when you did your work, she always tried to find a way to tell you, "you did a good job and keep it up". And sometimes she would reward you and sneak a sucker around over to you or something. (Chuck Rodgers) She just took a lot of time with you. When she saw that you were interested in something she would just; she would take a lot of time with students. She really would. She was more like a mother to you too. Yes, Miss Knight was very nice (Shirl Brack). They all cared; I think that was the main thing. They wanted you to learn, to know things. (Deloris Mason)

I would give nothing for it. Because from what I can see when I think back these people prepared us for the world because we were in a small coal mining town in Lynch, Kentucky but they knew we would go out into the world so therefore they tried to prepare us for the world. We could not use improper English or things of that nature. And I think they were doing their best with everything that they had to prepare us for the world, and I think they did a good job. Because when you think about on a whole, the people that came from these schools and in that town and in that community a lot of them have done well. And it's because of these people on this picture. (Cynthia Brown)

\author{
$* * *$ \\ The black children that attended the colored schools in Benham and Lynch, Kentucky \\ share strong, vivid, memories of their experience with "their" school. Although the \\ institution itself was created to damn them - as it existed solely to carry out a project of \\ racial subjugation and to perpetuate a white supremacist ideology — the black community \\ re-appropriated the colored school as a site of social ordering and cultural production \\ within the bounds of their own social world. Themes of value, care and self-making are \\ by no means limited to the colored schools in Benham and Lynch, as histories and other \\ studies of segregated black schools in other geographical contexts, such as North \\ Carolina (Cecelski, 1994) Florida (Shircliffe, 2001), and Washington D.C. (Stewart,
} 2013), demonstrate how blacks in America valued their colored schools in spite of the 
relative material deprivation that they faced vis-à-vis their white counterparts (V. S. Walker, 1996, 2000). What has emerged from this recent body of literature is an idealtype of the black school. Individual case studies of black schools throughout the South reveal a striking resemblance in terms of cultural approaches to pedagogy, organizational structure, and social interaction between black teachers, administration, parents and children. In her synthesis of all published works on segregated African American schools in the South from 1935 to 1969, educational historian Vanessa Siddle Walker (2000) characterizes the meta-description of black schools in the literature by four themes: 1) exemplary teachers, 2) curriculum and extracurricular activities, 3) parental support, and 4) leadership of the school principal. These findings about the black school are analogous to the ways in which other institutions within the black community that were born out of oppressive segregationist structures, such as the black church, emerged as the primary sites of black cultural expression in the $19^{\text {th }}$ and $20^{\text {th }}$ centuries (William Edward Burghardt Du Bois, 1903; Frazier, 1974; C. D. Walker, 2008).

Recent studies using current oral history data on former African American teachers, administration and students who formerly attended these schools reveal strikingly similar narrative frames used to describe their memories of the black school (Hamlin, 2012; Mungo, 2013; Shircliffe, 2001; Stewart, 2013; V. S. Walker \& Tompkins, 2004). While these studies do not overlook the gross inequality, financial and structural deprivation, and the social forces of racism upon which segregated schools were predicated, they do shed light on the cultural mode of African American pedagogy that emerged within this oppressive context. The resemblances in memory and experience are uncanny. Quoting an excerpt of an oral history interview from Schircliffe's 2001 study on 
the function of nostalgia in oral history narratives as they pertain to the de jure black school her participant recalled,

At Middleton as a student we were indeed a family. We were embraced by teachers, protected, taught everything that they thought we would need to get out there and improve the world, as such. Whatever you did in school, everybody knew it, your Mom also knew it. When you got home you were obedient. The worst thing you could do was probably skip a class or throw a spitball or something of that sort, because everybody really just took care of everybody. We were a proud, proud, proud group; a proud group of kids.

The orals testimonies of her participants in Hillsborough County, FL echo, almost verbatim, those of my participants in Lynch, Benham and Cumberland, , as do the testimonies from other studies I have come across focusing on the colored schools in North Carolina and Washington, D.C. This mode of being, community disposition, this structure of feeling that I have traced throughout this chapter and the one before it is prototypical of the genre of blackness that pervaded in the South.

\section{Black Pedagogy}

It is clear that the teachers saw themselves as role models. It is just as important to note and illuminate the ways in which their students perceived them. One of the perceptions consistent throughout the entire body of oral history interviews is that the students felt that they cared about them. In spite of all the strict oversight and punishments, rigid rules and high standards, there was no doubt in their minds that their black lives mattered in the eyes of their teachers. As we are experiencing in our contemporary moment in colleges and universities across the country, the issue of care and belonging is central to creating a healthy learning environment. It cannot be 
measured or quantified in the same way that other measures of academic environment can, instead it is a feeling that can only be validated by the those on the receiving end. Inherent in the intersubjective experience of giving and receiving care, is trust, responsibility and vulnerability. How did the black kids in Harlan County, Kentucky know their teachers cared?

They knew because their teachers spent time with them, to affirm good behavior and to redirect them when they were wandering astray. They did not have to $d o$ anything to receive it, they were care-worthy just as they were.

...Miss Mady Knight, she was down there at the black school. She was always teaching us. She was a music teacher; I think she was the history teacher too. And she would - she would always talk to us, especially young men, always make something up you know so she could spend time with us. And when we didn't do what we were supposed to during school hour they stayed up there at school, I don't care if it take two hours or three hours, and kept us there in class teaching us...they used to spend all the time with us and they didn't get the money for it.

--Sanford Baskin | Graduated Lynch High School | Class of 1965 | Integrated in $11^{\text {th }}$ grade

They had high expectations of them. The black teachers did not lower their standards for their black children. They believed in them and knew that they were capable to perform in society. To those teachers, black was not a disability.

Yes, I thought they cared. Because they had it hard, as far as getting an education. And they were trying to make sure that you didn't have that hard a time getting an education. You would be prepared when you go to college, to know something and then you can compete with other kids. And that's what they were about. As far as I was concerned, that's what I thought they were about. 
--Chuck Rodgers | Lynch High School | Class of 1974 | Integrated in X grade

... and she said, 'I'm going to make you learn'. You're going to learn here or you're going to stay here the next year, you're not going to get out until you learn it. And that's what she did. And she cared for you. Because if you're Black, I'll care for you. Evidently, she saw how things were back then when she was growing up so she said she had to make a difference. And evidently, she did.

--Richard Chapman | Lynch High School | Class of 19XX | Integrated in XX grade

They extended themselves beyond the classroom and let their students get a glimpse of them as human beings. Despite their position as esteemed teachers, those boundaries of respect were ever-present, but they were vulnerable enough to let their students see more than one side of them.

Miss Ellison was a home economics teacher and she taught a lot of girls how to cook and sew and how to be young ladies, that was her thing, and I love Miss Ellison. We used to go to her house all the time, and she was just nice. She was just, she was like I won't say mom to girls but she was like, she was ready to care about young lady to become a young lady and know how to take care of yourself...Yeah, then our teachers cared because if you didn't do your work and you was failing they would contact your parents, they would let your parents know. They would call them to come to the school believe me...

--Vera Peeples | Benham Colored School | Class of 1963

Moreover they held on the village pact. A black child was a community asset, and all adults had a part to play in rearing responsible members of society. Parents trusted 
teachers, and teachers trusted parents, and children trusted, feared, and revered their teachers and parents.

Oh yeah, so much so that our teachers made home visits, okay? Our teachers would visit the parents of each child and rest assured when that teacher showed up at the door that was not and by an appointment that they showed up. They knew what time or day that mama and daddy would be home and mama and daddy was not going to ever turn them away. And they could talk to mama and daddy about any of their children, any of my sisters or my brothers or whatever it is that whomever it was that they wanted to talk him about. And we would pray that they would always be good stories.

- Edgar James Moss | Benham Colored School | Class of 1958

Selecting excerpts for this section was extremely difficult because there are so many examples of the quality and character of education that the children received from their teachers in the black school. This does not mean that these institutions were without problems, as they were surely steeped in similar intra-racial problematics that plague the black community to this day—such as colorism and other forms of self-hatred, class bias, and patriarchy; but there is something qualitatively distinct about the black pedagogies that were emblematic of the colored school. Black teachers were committed to building high self-esteem, morals, and ethics in the souls of their black students in spite of what Jim Crow dictated about them. However, the plate glass of the veil always awaits.

\section{Encounters with the Veil}

As children, their seven-mile, three-town area was all they knew. Born into a segregated society, with parents and grandparents who ventured to Kentucky from 
Alabama, Jim Crow was an inherited structure, and one that they took for granted.

However school was one of the main sites where they, as children, learned that they were different than whites. The remainder of this chapter focuses on the interior, subjective, processes of racialization through the memories of childhood and schooling.

In the context of school, difference objectified itself through material deprivation. Although the "colored" schools in Benham and Lynch were considered to be the finest in the region, relative to the fourteen black public schools in the eastern Kentucky region, they paled in comparison to the normative white schools that stood not a mile away in each community. For example, although the Lynch Colored Public School was considered the premier black school in eastern Kentucky in terms of facilities and resources, it was originally constructed with a budget of $\$ 80,000$ in 1924 , while construction for Lynch High School was budgeted for $\$ 160,000$ in that same year. These material inequalities were experienced as a "sensation", as Du Bois would have it. Vivid memories of the feeling of "separate and unequal" often came to fore throughout the oral history interviews:

That's one of the examples. I don't remember receiving new books. I remember receiving the hand-downs that'd come from the white school. And there were other differences as well. For example, a graduated class athlete from Lynch High school would get jackets. They got jackets as a reflection of their athletic prowess. We fought to get sweaters, and I mean literally, sweaters. I remember when we first got the sweaters and how thrilled we were, because before then we could only just look in envy and disappointment at our counterparts at the white schools who were graduating and able to show what they had done. So you had absolute disparity in terms of resources and application of resources and allocation of resources and so forth. You also had differences with curriculum. And this didn't resonate with me until I actually got in college. Yes, we did not have; for example this is just one case in point. We did not have labs; laboratories. 
--Jerome Ratchford | Lynch Colored School | Class of 1960

But we practiced every day, five days a week on the same field. The white team, the Tigers at the east end field just as you were coming to the gate, and the black team, we were at the far end of field after you've come into the gate. But we never played against one another. So that was a negative. Many of the books that we used in the black school were used books from the white school. Now, Professor Matthews would send five or six boys to the white school to get books, used textbooks to be brought back to our school to be used again. And many times the books were all torn and tattered and had pen and pencil marks all through them. There were times that we would, we just - we made the best of what we had.

--Edgar James Moss | Benham Colored School | Class of 1958

When we started buying books they were new books, that was from the $9^{\text {th }}$ grade on that you had to buy your own books. But up to the $8^{\text {th }}$ grade we would get books, but they were second hand books that came from the White school. It pisses me off every time I think about it. Because the white kids were all sponsored by the same company as us, but we were the ones that got the damn secondhand books.

--Willie French | Lynch Colored Public School | Class of 1960

Now, this is what happened with that; if your parents could not afford to buy you books - sometimes you got books that were handed down from the White school and you would find all kind of names like nigger and all that kind of stuff written in the books.

--Jacquelyn Garner | Lynch Colored Public School | Class of 1963

It is these "little things", the internalized unarticulated, nonetheless symbolically violent, micro-aggressions, within the broader structure of oppression that conditioned a 
particular racialized subjectivity. What we can gather from these statements is that the encounter with the used or absent object engendered feelings of desire and shame-from Jerome Ratchford's experience of looking on with "envy and disappointment" to Moss' bringing of the "torn and tattered" books from the white school to the black school to Garner greeted with the word "nigger" when she opened her math book on the first day of school.

As the previous chapter demonstrated, racial segregation is one of the key mechanisms at work to perpetuate and reinforce cognitive fissures between racialized and racializing social worlds. This rings especially true in the context of de jure segregation of blacks and whites in the American South, an era when the uneven hand of Jim Crow loomed large in the everyday lives of all human beings. Jim Crow codes were explicitly embedded into State laws,- - ordering segregation of schools, railcars, and public recreational spaces amongst other contexts— but these laws also pressed a particular set of mores upon black and white bodies, reifying ideologies of racial inferiority/superiority. Once internalized, racial ideologies dimmed the possibility to, as Immanuel Levinas says, "see the face of the Other" and instead created the conditions for affective segregation. Under these conditions Du Bois (1903) tells us that "there is almost no community of intellectual life or point of transference where the thoughts and feelings of one race can come into direct contact and sympathy with the thoughts and feelings of the other". This certainly rang true for the black and white communities in Benham, Lynch and Cumberland.

Schools played a central role in inculcating the Jim Crow ideology in the hearts and minds of all individuals; children and parents, black and white. Revisiting 
Althusser's (1971) theorization on the relationship between subject formation and the school where he avers, "nevertheless, in this concert, one Ideological State Apparatus certainly has the dominant role, although hardly anyone lends and ear to its music: it is so silent! This is the School." It is the very everydayness of the school, the machination of going in day in and day out along with all of the other kids in your community, being split into classrooms by age, playing or cheering by gender, or walking to the west or east side of town by race that makes it the ideal breeding ground for making difference real.

\section{Praxis}

The Lynch and Benham Colored Schools served the black school-aged children in their respective towns up until 1963. As a non-company town, Cumberland had no incentive to provide educational services to its black population and instead opted to bus their black children to Benham. A graduate of Benham Colored School puts it squarely:

"You will have to recall that segregation prevailed and Cumberland had a white school, it did not have a colored school. So there was an agreement that the colored kids in Cumberland would attend the school in Benham. So the kids in Cumberland were transported by bus to Benham School and that's where we went to school"

--John Steward | Benham Colored School | 1960

Everyday, on their way walking, driving, or bussing to school, most blacks had to pass Benham High School, Lynch High School, or Cumberland High School— normatively named for the normal "American" children — before they reached their marked "colored" school. This mundane quotidian practice contributed to the formation of a racialized version of what Pierre Bourdieu termed habitus — "systems of durable, transposable dispositions, structured structures predisposed to function as structuring 
structures, that is, as principles which generate and organize practices and representations that can be objectively adapted to their outcomes without presupposing a conscious aiming at ends or an express mastery of the operations necessary in order to attain them."

Most participants resolve their reflection on attending segregated schools down to a very simple, yet loaded, phrase: "That's just the way it was". The "structuring structures" of school segregation normalized practices and behaviors to the extent that they went largely unquestioned. When asked if they ever wondered why they attended separate schools, two participants elaborated:

No, I never did. We went to our high school and they went to their school, and we liked our school as well as anybody ever could. I guess we thought our high school was the only school there was. I mean, we didn't think about them and their school. We never thought about that being a school. I mean, school was where we went to school.

--Willie French | Lynch Colored Public School| Class of 1960

Yeah we passed them. And there was this little white girl we would used to say "she better not come on our side!"; but it was not like we started anything. It's like they knew their side and we knew our side. We would pass by them every day, going back and forth, because they are coming up our way and we are going down their way; although we should have all gone to the school that was closest by.

\section{--Patricia Liggins | Lynch Colored Public School | Class of 1963}

As these quotes illustrate, this unquestioning was not bereft of a subjective understanding of their racialized positionality. This is apparent in the consistent deployment of the demonstrative terms "we" "our" "they" "theirs" "them", to delineate one social group from the other. Sociologist Robin Wagner-Pacifici (2010) argues that demonstratives not only situate the nature of events, but they also "become particularly charged in historical 
transitions in which identities change or in which the identity differences are being highlighted or elided."

\section{A Change is Gonna Come}

The school also interpellated a particular type of subjectivity for all actors in the black community. Children were conditioned through relentless discipline, surveillance, and tight-coupling amongst teachers and parents to be obedient, without question, to all adults in the community. However this obedience did not come without a deep collective sense of trust. Parents trusted that teachers, and other adult community members, had their children's best interest at hand. Therefore all black adults were deputized with the authority to discipline a child as they saw fit. The child was community property. And they lived the old African proverb "it takes a village to raise a child".

However, this context of extreme discipline and punishment is not dismored from history or memory. Coming from the Deep South off of the plantations of Alabama, black mothers and fathers understood all too well repercussions of one member of the community "forgetting their place". Unlikely was the possibility of each individual being accountable for his or her own behavior, for to whites, in the event of a misunderstanding, a nigger was a nigger. Therefore, the consequences of one transgression could easily bear down on the entire community. In this sense, intra-racial conformity was very much a strategy for survival. This was also steeped in the notion that each individual person represented the entire black race. 
Jerome Ratchford's experience with his high school teacher, Mrs. Hatch,

embodies these sentiments of care, community involvement, trust, as well as the notion of representing one's race. I met Dr. Ratchford in his office at Kennesaw State University to conduct his oral history interview, where we had a lively conversation about a range of topics, including his upbringing in Lynch, Kentucky. When I shared the photo with him, he immediately started affectionately identifying the people represented in the document. I asked him if he could share a story about one or two of his teachers that left and indelible mark on his life:

Yes. And for me it was - she's not amongst those on that photograph. But I literally owe everything that I have accomplished to her. And her name, the last name is Hatch. Mrs. Hatch. She, like many of them, migrated from Central Kentucky; in her case I think it was Ohio, very near Central Kentucky and so forth. And she came more than capable to Lynch; more than capable as a teacher. And she taught history and she taught - well, history, social studies and so forth. And she wanted to expand our knowledge and awareness; I particularly remember her adding current events to her teaching curriculum. But the thing that stands out with me with her is that when I started at the South East Center, which is the extension of University of Kentucky, and my classmates, we constituted the first cohort going there.

It was the first desegregated opportunity - certainly in that community, but I daresay in southeastern Kentucky. Our desegregation ironically occurred at the higher education level. It didn't occur like it occurred throughout the country, typically high school and then sometimes even earlier than that. Well, after one year, she knew it was very, very important for me to stay at the extension center in South Eastern Kentucky for lots of reasons. She probably understood that we needed successes, she understood what it meant for me personally; probably a lot of things and so forth. But I was poised not to be able to continue to go to school there, because my father had been downsized, as we say today, laid off then.

And so that mere tuition amount of only less than $\$ 100$, we actually didn't have that amount of money. And so there was a probability that after one year I would stop. And I don't know how she found out about it, but she came to my house and told my parents that she didn't want to be intrusive but she was willing to give me, my family, the tuition money; and gave it to my family, okay; for me to stay in school. 
And so I'm ever - and I was filled with tears in my eyes as well. I'm ever indebted. Obviously, I was able to pay her the money back. But more important than paying the money back is passing on the legacy. So when I go back and I think about why I have been facilitative, certainly of black kids having opportunity to higher education; but any child having an education. That's the foundation for it. If there's anything that I can do to catapult or influence someone else achieving his or her goals academically, particularly in higher education; I will do that. The foundation for that was Mrs. Hatch, for me. Yes.

--Jerome Ratchford | Born 1940 in Lynch, | Resides in Atlanta, GA

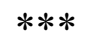

Established in 1960, the South East Center was one of nearly a dozen satellite branches of University of Kentucky as an attempt for the university to diversify its regional intra-state student population. The center gave young people from the, otherwise foreign, Appalachian region of Kentucky access to the state higher education system by offering an associate degree program in Cumberland. It was also a direct pipeline to University of Kentucky's main campus in Lexington, where those who demonstrated the merit and fortitude to continue their education went on to attain their bachelors degree. Jerome Ratchford was one such person. In fact, he went on to attain a Ph.D. in education from Bowling Green State University, and has subsequently maintained a career in academia, until recently, when he retired from a Deanship at Kennesaw State University.

However, as his story illuminates, his college pursuits were tenuous from the start. The mines were beginning to close, and his father was one of the many men who were laid-off in the process. Better yet, the urban centers in the Midwest and Northeast were experiencing an industrial boom. So while Dr. Ratchford's peers were migrating to the 
city to get factory jobs to make money, or volunteering to serve in the military to travel the world, he was one of six black students who were identified by the teachers as the "talented tenth" and selected to join the first cohort of the satellite system.

Reflecting on his feelings at that time, Dr. Ratchford felt that he was left behind by staying in college because his peers were out "doing" something. College did not present itself as a clear pathway to mobility at the time. And even if it did, there was no cultural resource to model. Therefore, beyond his own personal well-being, Mrs. Hatch understood, as Dr. Ratchford put it, that "we needed successes". Coming to his home to see his parents, and offering to pay Jerome's tuition at a time when the family was going through a difficult and perhaps shameful time, required a deep level of trust, care and intimacy between Mrs. Hatch and the Ratchford family.

Underlying this act of generosity was Mrs. Hatch's understanding of what was at stake. She knew what most other teachers and adults knew: a change was coming to the Tri-City area; one for which the black children must be prepared. South East Community College was the first integrated educational institution in southeastern Kentucky, and it foreshadowed the desegregation of the public education system in the region. Jerome Ratchford and his five black counterparts were a signal to the community that black students could perform and thrive in an integrated society. 


\section{CHAPTER FIVE}

\section{The Hidden Injuries of School Desegregation}

If you look up there right there today in concrete it says Lynch Colored School...Its right there today- the blacks call it West Main High you know. But it's written out there: Lynch

Colored School. See because we went through a transformation as to who we were-we went from Colored, to Negroes, to African-Americans... and Black. We went through all of those. -Albert Harris | Born 1950 in Benham, | Integrated in $8^{\text {th }}$ grade

\section{Introduction}

This chapter focuses on the phenomenological transformations that accompanied the event of school desegregation from the perspective of the African Americans who matriculated through the "colored schools" in the towns Benham, Lynch, and Cumberland, Kentucky. I specifically attend to the psychosocial effects of this structural transformation on the black community as they entered into the normative structures of "mainstream" American society. What were the ways in which black children made sense of their racialized subjectivity and their community before and after the historical transformation of the so-called "integration" of public schools?

The extant literature shows that the implications of the segregated school system are much more complicated than structural concerns about separate and unequal (J. D. Anderson, 1988; Cecelski, 1994; Mungo, 2013; Shircliffe, 2001; V. S. Walker, 1996). At the core of the institutional logics of this system are complicated questions of African American and American identity, belonging, and citizenship. If the colored school 
interpellated a certain type of black subjectivity—one that was both acted upon by the state and auto-instituted through the private social interaction amongst black teachers, parents and students - then what are the ways in which the event of school desegregation transformed the subjective meaning and perception of being "black" in society? I argue here that the 1954 Brown vs. Board of Education decision pierced the broader American imagination, sanctioning the possibility of new epistemological structures for all American citizens to perceive and situate their subjectivity within the national tabula rasa. In other words, Brown vs. Board of Education inaugurated the African American subject.

\section{Battleground for Citizenship}

By the early 1950's blacks in the South were still living under the overtly racist mandates of the Jim Crow caste system, while those in the North were experiencing a more veiled, yet equally oppressive, form of de facto racism. However, by that time, two to three generations removed from slavery, a black professional and middle class had emerged in America. While the majority of the black population still held working class positions as laborers on the lowest rung of the segmented labor economy, black communities were peppered with their own doctors and dentists, real estate agents, teachers and professors, attorneys, nurses, and all manner of professions. Together, blacks were mobilizing more than ever to demand that America, as Martin Luther King, Jr. (1963) would later say, "cash its promissory note" to grant all her people the guarantee of the "unalieble right" to "Life, Liberty, and the Pursuit of Happiness".

At the top of the agenda was the systematic dismantling of Jim Crow, and Civil Rights leaders, especially those the NAACP, identified the school as the ideal 
battleground to rearticulate the meaning of citizenship for the negro in America (Marshall \& Tushnet, 2001; Ogletree, 2004). The NAACP filed a series of civil rights lawsuits from the 1920s onwards demanding that an individual black plaintiff be admitted into graduate and professional schools at specific American public universities; namely the State of Missouri vs. Gaines (1938), Sweatt vs. Painter (1950), and McLaurin v. Oklahoma State Regents for Higher Education (1950). Many of these suits resulted in victories. For example, in 1946 Herman Sweatt was denied admission to the Law School at the University of Texas because, as a segregated institution of higher learning, there was no place for black Herman. Although the NAACP lost the case in state court, they appealed to the U.S. Supreme Court and won. In 1950, the Court ordered the University of Texas to integrate its School of Law and its Graduate School. In the Sweatt case and those like it, NAACP lawyers argued that there was no equivalent alternative institution for their plaintiff's to attend in their state, thus making the "equal" in "separate but equal" impossible to access. All of these early cases worked within the framework of the separate but equal doctrine affirmed, over fifty years earlier in 1896, with Plessy vs. Ferguson.

However, in 1952, the NAACP filed a set of class action suits in five statesDelaware, Washington D.C., South Carolina, Virginia, and Kansas - that culminated into the landmark Brown vs. Board of Education decision of 1954. Unlike the previous cases that argued for equal educational access in the absence of separate and equal institutions, the attorneys in Brown argued that the very existence of a racially segregated educational institution was in fact unequal. The previous cases provided enough precedence to support their arguments. Legal scholar Charles Ogletree, Jr. (2004) asserts that "the Court 
had supported the "equalization" strategy, but Brown asked it to switch horses in midcourse and revisit Plessy as a whole." Also unlike the previous cases, the battleground for Brown was not the sphere of higher education, but the entire U.S. public school system.

\section{The Case}

The case was originally argued before the Supreme Court on December $9^{\text {th }}$ and $10^{\text {th }}$ of 1952. John W. Davis, Esq. represented the appellees-the various boards of education — and Thurgood Marshall the appellants—-the black children represented in the class action suit, who really represented all black children in America. Using a different approach than in his previous cases, Marshall argued on the basis of the inherent inequality of racial segregation of schools. Marshall explains to Chief Justice Vinson,

"At the time, counsel for the appellants, however, made the position clear that the attack was not being made on the "separate but equal" basis as to physical facilities, but the position we were taking was that these statutes were unconstitutional in their enforcement because they not only produced these inevitable inequalities in physical facilities, but that evidence would be produced by expert witnesses to show that the governmentally imposed racial segregation in and of itself was also a denial of equality."

Marshall and his team drove their point home through the expert witness testimony of Dr.'s Kenneth and Mamie Clark, two African American psychologists at City College of New York (CUNY), who presented findings from their experimental research on children's attitudes towards race — the famous black doll-white doll experiment. Similar to Virginia Ward's response in Chapter Three, where she threw the white doll she received as a Christmas gift across the room in disgust, children in the Clark's study- 
black and white - associated the black doll with "bad" and "ugly" and the white doll with "good" and "beautiful". Most damning for the opposing team was that although the black children projected negative associations onto the black doll, they claimed that those were the dolls with which they most closely identified. This evidence gave Marshall the evidence needed to argue that segregation had not only negative economic, but psychological effects on children. With this scientific ammunition Marshall argued:

"Witnesses testified that segregation deterred the development of the personalities of these children. Two witnesses testified that it deprives them of equal status in the school community, that it destroys their self-respect. Two other witnesses testified that it denies them full opportunity for democratic social development. Another witness said that it stamps him with a badge of inferiority. The summation of that testimony is that the Negro children have road blocks put up in their minds as a result of this segregation, so that the amount of education that they take in is much less than other students take in."

In defense of the status quo, Davis and his legal team relied on three logics to support their argument to maintain state imposed segregation of public schools: original intent, white intolerance, and fear. The Court had used the first argument to support legal racial subjugation, original intent, since the years following the ratification of the Constitution. The premise of the argument requires the Court to ask what the original intent of the framers was at that time the Constitution was drafted, basically asking "did the framers intend for these rights to be extended to the non-white population?" In this case, “Are the Negroes citizens or subjects of the United States of America?" Davis begins his argument speaking of the Fourteenth Amendment:

“...the effort in which I am now engaged is to show how those who submitted this Amendment and those who adopted it conceded it to be, and what their conduct by way of interpretation has been since its ratification in 1868."

Confused, Associate Justice Frankfurter pressed Davis: 
Justice Frankfurter: What you are saying is, that as a matter of history, history puts a gloss upon "equal" which does not permit elimination or admixture of white and colored in this aspect to be introduced."

John Davis, Esq.: I am saying that.

Justice Frankfurter: That is what you are saying?

Moving on from this awkward moment, Davis then proceeds to his other two arguments, ones that he believed attended more directly to the contemporary moment - that Negroes are a biologically inferior race. His second argument was that irrespective of the constitutionality of separate but equal, whites simply did not want to mix with blacks, and this reality was enough not to proceed. To support this argument, he used (mis)quotes taken from papers and speeches delivered by a host of scholars, including leading Sociologists Howard W. Odum and W. E. B. Du Bois. In his analysis of this moment Ogletree explains that "those representing states forced to integrate after Brown argued that the Court's ruling could do irreparable harm; there would be sustained hostility by whites, withdrawal of while children from integrated schools, racial tensions, violence, and loss for jobs for black teachers. Some opponents of integration went to extremes, arguing that integration could bring blacks with lower IQs into the schools, that many black children were retarded, and that tuberculosis and venereal disease would spread, as would the enrollment of illegitimate children. Their point was that integration would destroy their way of life." Relying on this latent sentiment of fear and supremacy Davis avers,

"It is not the height of wisdom that the manner in which that shall be conducted should be left to those most immediately affected by it, and that the wishes of the parents, both white and colored, should be ascertained before their children are forced into what may be an unwelcome contact?"

After hearing Davis' arguments, Marshall, in his rebuttal the next day, went for the 
jugular.

"So far as the appellants are concerned in this case, at this point it seems to me that the significant factor running through all these arguments up to this point is that for some reason, which is still unexplained, Negroes are taken out of the main stream of American life in these states. There is nothing involved in this case other than race and color, and I do not need to go to the background of the statutes or anything else. I just read the statutes, and they say, "white and colored."

Marshall makes plain that Davis' arguments are solely based on racism, not the legal statues upon which they are bound to refer. With the arguments presented over the course of this two-day Supreme Court case, Thurgood Marshall, as Stuart Hall would say, rearticulated the American Citizen.

The Decision: Brown vs. Board of Education of 1954

Those of the "colored" race—-the Negroes—became African American on that day of May $17^{\text {th }}, 1954$, and John Davis, Esq. and his legal team found themselves on the wrong side of history. Although it took an unprecedented sixteen months, the Supreme Court returned with a unanimous decision. Authored by newly appointed Chief Justice Warren ${ }^{15}$, the Court opinion opens with the statement:

"Segregation of white and Negro children in the public schools of a State solely on the basis of race, pursuant to state laws permitting or requiring such segregation, denies Negro children the equal protection of the laws guaranteed by the Fourteenth Amendment - even though the physical facilities and other "tangible" factors of white and Negro schools may be equal."

With a deft legerdemain, Chief Justice Warren affirms Marshall's original argument and disparages Davis'; for not two sentences later he states:

"The question presented in these cases must be determined not on the basis of

${ }^{15}$ Chief Justice Vinson had serendipitously died in 1953, eight months before the Brown ruling. Legal scholars speculate that had he lived, the Brown decision would have went the other way. 
conditions existing when the Fourteenth Amendment was adopted, but in the light of the full development of public education and its present place in American life throughout the Nation."

Relying not on the precedent of "separate but equal", affirmed by Plessy vs. Ferguson in 1896, the Supreme Court decision that had determined the outcome of the half dozen education-based NAACP cases that preceded Brown, Warren and his fellow Justices relied on the new testimony introduced by the Clark experiments.

"To separate them from others of similar age and qualifications solely because of their race generates a feeling of inferiority as to their status in the community that may affect their hearts and minds in a way unlikely ever to be undone...A sense of inferiority affects the motivation of a child to learn. Segregation with the sanction of law, therefore, has a tendency to retard the educational and mental development of negro children and to deprive them of some of the benefits they would receive in a racially integrated school system. Whatever may have been the extent of psychological knowledge at the time of Plessy $v$. Ferguson, this finding is amply supported by modern authority. Any language in Plessy vs. Ferguson, contrary to this finding is rejected."

A victory no doubt, this landmark decision came with one string attached, that local communities enforce the desegregation of public schools with "all deliberate speed." These three words compromised the decision from the outset, "as the "all deliberate speed" language meant "slow". Using the same logic as gradual emancipation legislation, school desegregation was to happen "in due time" to appease white fear and anger about the idea of their children mixing with the colored race, and Ogletree (2004) rightly observed that this meant that "resisters were allowed to end segregation on their own timetable.” In Harlan County, , that meant 1963.

\section{Negro Discourses on Negro Education}


The question of the future of black education in America loomed large within the black community. The debate of the day amongst the black intelligentsia concerning education was whether or not black children needed integrated schools in order to be able to compete in American society (W. B. Du Bois, 1935; Hurston, 1955). By the end of Reconstruction, nearly all colored schools in the South were taught by black faculty, and, although under the jurisdiction of white superintendent boards, the day-to-day administration of these schools were left to black principles and teachers. There was a question as to whether black students would and could thrive in an integrated society if left to the institutional structures and day-to-day prejudices of a white supremacist system.

In his simply titled article, "Does the Negro Need Separate Schools?, W.E.B. Du Bois (1935) carefully weaves an argument that asserts that surely an integrated school system would be ideal, as it would foster a richer cultural experience and greater self confidence for both black and white students. However, he de-romantizes the notion of such an environment through a sober warning that:

What he must remember is that there is no magic, either in mixed schools or in segregated schools. A mixed school with poor and unsympathetic teachers with hostile public opinion, and no teaching of truth concerning Black folk, is bad. A segregated school with ignorant placeholders, inadequate equipment, poor salaries, and wretched housing, is equally bad.

Du Bois' conclusion articulates the paradox of the day. For the black community, the question of the possibility of true "integration" was one of mutual recognition and equality. The material act of school integration would be rendered inconsequential, or better yet, harmful, without it. This uncertainty loomed large in the moments leading up to and immediately after the Brown vs. Board of Education decision and carried on up until school desegregation (Cecelski, 1994; Diehl, 2007; Hamlin, 2012; Wolff, 1963) was 
finally enforced throughout local public school districts — which in some cases took a full two decades to come to fruition. This caused a great deal of anxiety and irresolution within the black community.

For example, anthropologist and public intellectual Zora Neal Hurston (1955), who was on the outs with much of the high society black community at the time, although knowingly way left of the argument vis-à-vis her peers just could not hold her tongue on the matter. In a letter to the Orlando Sentinel in 1955, just one-year after the Brown decision came down from the Supreme Court, Hurston opens her letter by resigning herself to the ridicule she will certainly receive for her trenchant critique. She writes:

"I was not going to part my lips concerning the U.S. Supreme Court decision on ending segregation in public schools of the South. But since a lot of time has passed and no one seems to touch on what to me appears to be the most important point in the hassle, I break my silence just this once. Consider me as just thinking out loud. The whole matter revolves around the self-respect of my people. How much satisfaction can I get from a court order for somebody to associate with me who does not wish me near them?"

In line with Attorney Davis' argument in Brown, Hurston sees this as an issue of will and desire. To that extent she argues that she would much rather prefer what she called "ethical and cultural desegregation" to the forced desegregation of black and white bodies. She also had faith in the possibilities of the colored school system. Through concerted equalization efforts, she believed that black children could receive an education equal to whites, sans the emotional cost evidenced by the Clark findings upon which the Brown ruling hinged.

If there are not adequate Negro schools in Florida, and there is some residual, some inherent and unchangeable quality in white schools, impossible to 
duplicate anywhere else, then I am the first to insist that Negro Children of Florida be allowed to share this boon. But if there are adequate Negro schools and prepared instructors and instruction, then there is nothing different except the presence of white people. For this reason, I regard the ruling of the U.S. Supreme Court as insulting rather than honoring my race.

The integration question loomed large within the black community, and the discourse was certainly not limited to the black elite class. Black principles and teachers on-the-ground had strong views about the best course of action for the next generation of the young, gifted and black (Fairclough, 2009). They also had to wonder at what desegregation would mean to their careers: "would integrated schools leave the black teacher as an obsolete artifact?" Parents and children worried too: "would black children be able to keep up with their white counterparts?" For hundreds of years blacks have been told by society that they are inferior to whites - an integrated school presented itself as the site where some of our worst fears may have materialized.

Scholarship on school desegregation primarily focuses on the Brown vs. Board and its legacies (Allen, 2009; Bell, 2004), the socioeconomic effects of the landmark decision on black and white children and professionals (Fairclough, 2004), and the context of segregated and desegregated schools before and after Brown (V. S. Walker, 1996; Wolff, 1963). Throughout this vast literature, however, there is one group whose voices have been largely left out of the analysis: the African American children of integration - that generation of black children who experienced the process of school desegregation during the 1950s, 60s, and even 70s. While parents, Civil Rights activists, and public intellectuals did the work of framing the issue of school desegregation and seeing it through to the Supreme Court, few in that generation would ever actually experience integrating a school—-they were grown, they had their degrees and professions and families. It was instead their children who would be the primary agents of history in 
this epoch transformation. The remainder of this chapter examines how this generation of African Americans in the Tri-Cities area of Harlan County, Kentucky experienced school desegregation. As my primary matter of concern throughout this text is the racial self, I follow this analysis by tracing the moments of transformation in their subjective understanding as racialized subjects and citizens in these United States.

\section{At the Eve of an Era: Anticipating Integration}

The years between 1952 - the inception of the Brown v. Board arguments—and 1963 - the year that the school system in the Tri-Cities area, marked the eve of an era of Jim Crow segregation in Harlan County, . This window in time was a moment choc-full of anxiety and anticipation. In the years leading up to desegregation, teachers augured the inevitable change to students and parents. Although they may not have been privy to the exact year that the school system would consolidate, they knew that it was only a matter of time before the educational structures would be transformed in their community. One graduate of the class of 1961 recalls that, although he did not integrate, his teachers constantly braced him for the possibility:

I remember the two things they hammered in my head...You get an education you're not going to be able to get no job in no coal mine so you better get your education so you'd be able to get something to do. Second was you better learn something, learn how to compete in an integrated society because segregation is going to end. From the $1^{\text {st }}$ grade all the way through high school I heard that, I don't know how many times.

--Victor Prinkleton | Born 1943 in Lynch, | Graduated LPCS 1961

The black teachers at LCPS strove to prepare their students not only to coexist but to compete in an integrated society. In their framing, the underlying logic of their desire to compete was still grounded in the us/them binary that was embedded in the 
epistemological structure of Jim Crow society. For them, instilling a strong sense of self-confidence and capability in their black students before integrating was a prime responsibility. It was just as important for their students to believe they were prepared as it was for it to actually be so:

...they took an interest in what you were doing education-wise and they saw to it that you were prepared - you know when I came down University of Kentucky I was not afraid that I could not compete or anything like that. I mean that just was not in my nature. And so I can do the same thing you're doing. And that's the way they prepared us: to be as good, better than anybody else.

Lee Arthur Jackson | Born 1950 in Lynch, | Graduated Lynch HS 1968

The feeling that one has to work twice as hard or to be twice as good to accomplish his or her goals in mainstream society is a common sentiment across ethnically and racially marginalized communities. Many teachers at the LCPS balanced this subjective pressure to out-perform with unwavering encouragement that their natural abilities were more than sufficient and that they were not coming from an ontological position of lack. However, not all teachers truly embraced the idea of integration, and some did not bother to hide their contempt. One interviewee remembers her fifth-grade teacher, Ms. Jackson, one of the original teachers hired onto the LCPS faculty in 1924, discouraging the class year before integration:

...And I can remember her saying, "you're going to be like a lost ball on the highways of Georgia next year when you go over to the other school". And I always felt like you know "if we are it's your fault. You're not preparing us to go to be integrated", but that's what she would tell us. She was just really mean.

--Brenda Combs | Born in 195X in Lynch, | Graduated Lynch HS in 197X 
The promise of school desegregation impacted the entire African American community. Teachers were tasked with preparing their students mentally and emotionally for the coming transition, even though they themselves did not know exactly what to expect. Few teachers had first-hand experience with integrated academic environments, as the majority of them had been educated in the "colored" school system and later on at historically black colleges. They also had to deal with the uncertainty of their own futures. Integrating the school systems meant that there would be redundancies in human resources at almost every level; from administrators and faculty down on to the janitors. Parents did their best to instill a sense of pride and confidence in their children, reinforcing the nurturing and structure that they received from their teachers. However, the only one's who would actually come to fully experience the transition were the children of integration.

\section{A Theory of Cultural Trauma}

Their collective experience with school desegregation was traumatic. The sociological literature on trauma largely focuses on how societal discontinuities are generative of collective identities. Kai Erikson (1976) introduced the concept of "collective trauma" through his empirical examination of the psychosocial effects of a devastating flood in a mining town in Appalachia. Since Everything in its Path, much has been written about the linkages between memory, trauma, and identity at the collective level. More recently, Alexander, et.al. have brought the topic of trauma back to fore in their book Cultural Trauma and Collective Identity (Alexander, Eyerman, Giesen, Smelser, \& Sztompka, 2004). Cultural trauma theory examines the formation of 
collective identities in terms of how they are constructed through the collective memory of shared traumatic events - defined as "a memory accepted and publicly given credence by a relevant membership group and evoking an event or situation which is a) laden with negative affect, (b) represented as indelible, and (c) regarded as threatening a society's existence or violating one or more of its fundamental cultural presuppositions (Alexander et. al.,44).”

Ron Eyerman's work on cultural trauma theory specifically focuses on African American identity; locating slavery as the "primal scene" of its formation, and the fin de siècle New Negro movement as its post-emancipation rearticulation (Eyerman, 2001, 2004). According to him, "slavery was traumatic in retrospect" as it "formed the root of an emergent collective identity through an equally emergent collective memory, one that signified and distinguished a race, a people, or a community depending on the level of abstraction being put forward." (Eyerman 2001, p. 1). The New Negro movement was an intentional effort by blacks to re-present the "African American" to society as a cultured, dignified, capable subject as opposed to the mainstream conception of the "old" Negro as a childlike, shiftless, and subhuman figure. These representations were mainly circulated through cultural forms such as music, literature, and art, culminating into the Harlem Renaissance.

Both of these sites of African American identity formation emerge from the collective hope and desire for full citizenship and mutual recognition from mainstream society, and the continual devastation of being denied those rights. Therefore, school desegregation, and the broader Civil Rights era, is often situated as a defining moment in instantiating what some call a "post-racial" society, in which American identities are 
freed from being tethered to racial categories and legacies because we no longer "see" race. However, as my analysis in this chapter will demonstrate, in addition to moving forward, the process of school desegregation evoked a sense of trauma and loss at the community level for the African Americans who experienced this epic transformation. These findings do not impose a value judgment on the success or failure of school desegregation, it does however attend to what Sennett and Cobb (1972) would call the "hidden injuries" of school desegregation.

\section{The First Three}

\section{The First Three}

The colored schools in Benham and Lynch graduated their last classes in the spring of 1963. The school board in Lynch, decided that it was best to adopt a model of gradual desegregation, in which the $10^{\text {th }}, 11^{\text {th }}$, and $12^{\text {th }}$ graders would participate in the first phase of integration, with the remaining student body following suit over the course of a few years. Mr. Coleman, the principle of the Lynch Colored Public School at the time, held a community meeting in the gym to break the news to the students and parents about the coming transition. The students in those grades - the first three-who would go on to become the class of 1964,1965 , and 1966 , were about to encounter something with which most adults in the community had no experience; competing in an integrated social environment. When I asked participants to "take us back to 1964 when you first integrated", members of those classes share vivid, emotional memories of their initial encounters with school desegregation: 
You know sometimes I try to go back to that, and I'm not sure if I can remember and that may be one of those kinds of things that you try to put out of your mind...because it was something that I didn't want to happen. All the way through high school you look forward to the day when you're the big one, that you're the senior. And they took that away from us, just flat took it away from us. I looked through one of the yearbooks and I looked at a lot of the awards in different groups, they have different things. They were all white kids in our senior year and I think most of that probably was already done; it was already decided before we went up there. The only thing that we really fully integrated into was sports, football and basketball.

-Porter G. Peeples, Born 1945 | Class of $1964 \mid$ Integrated in $12^{\text {th }}$ Grade

When Professor Coleman announced in the gym that that would be our last year, it felt like something stabbed me in my heart because I didn't want to leave.

\section{-Shirl Baskin Brack, Born $1947 \mid$ Class of $1965 \mid$ Integrated in $11^{\text {th }}$ Grade}

The original experience going to the integration aspect to me was just a using process. What I mean in a using process is that they didn't want us there. White society really didn't want us there, but they had no choice in it. I really didn't even want to be there; I really didn't. I didn't want to be there because I knew it was just a using aspect to try to get the best black athletes. And it was just a using experience. They still went their way and we still went our way. We just went to school with them but you still were not given the props to which you demanded. You could excel in a great many things, but you still were not going to get recognized for it.

-Jack French, Born 1945 | Class of $1964 \mid$ Integrated in $12^{\text {th }}$ Grade

Although school desegregation impacted the entire African American community, the members of those first three classes by far express the strongest sense of trauma, loss, and melancholy over school desegregation. Even now in their late sixties, going back to that time often brought them to tears. The above excerpts are representative of the overall sentiment conveyed by the majority of the people in my sample; for them, school desegregation was an abrupt encounter with erasure: one that negated the value that they placed on their institution, rendering them invisible with the exception of their athletic 
prowess. The subjective experience with school desegregation reverberated throughout the entire student body, even with respondents who "went up to the white school" as early as third grade. One consideration that was clearly overlooked at the time, as it is also in contemporary research, is that African Americans valued their institutions, in spite of the apparent structural inequality. As I showed in the previous chapter, the colored school was a distinct cultural formation within the black community and contributed greatly to the formation of a distinctly African American identity.

The heartfelt responses from this cohort necessitated a deeper analysis. On the surface, the notion of being the first to experience such a meaningful community-level structural transformation was traumatic sounds reasonable. However, the consistent responses begged the question: what was the underlying injury that created this unhealed wound amongst this generation of African Americans?

Although Brown vs. Board of Education was decided in 1954, no public school in Harlan County showed any effort to desegregate the school system. The South East Community College, arriving as an always already integrated institution, was a glaring signal to the community that times were changing. And on March X, 1963, the Tri-City News announced that the Lynch Independent School District would desegregate the following year. The same went for the schools in the rest of the county.

Although school desegregation impacted the entire African American community, the members of those first three classes by far articulate the strongest sense of trauma, loss, and melancholy over school desegregation. Porter G. Peeples' above statement is representative of the overall sentiment conveyed; for them, school desegregation was an encounter with erasure. However, the subjective experience with school desegregation 
reverberated throughout the entire student body, even with respondents who "went up to the white school" as early as third grade.

\section{The "Hidden Injuries" of School Desegregation}

The mandate to integrate two competing institutional logics, cultures, and classes of citizens was a daunting challenge for communities all across the South. What my analysis reveals is that in Benham, Cumberland and Lynch-like hundreds of other communities - school integration never truly took place. Herein lies the crux of the injury for the children of integration. At the heart of the matter was an issue of distrust, fear, and misrecognition (Allen, 2004; Teiken, 2014). Could the enforcement of Brown v. Board of education transform the "us" and "them" that hundreds of years of slavery, Jim Crow, and racial violence crystalized in the minds of American citizens into a "we"? And does achieving "we-ness" require assimilating into one (the unum) or can many parts of a civil body come together as a whole? Participants frame their experience in going through this process of transformation in terms of loss, care, and transforming epistemologies.

\section{Loss of Community}

When the schools desegregated in 1964, the black students who formerly attended the colored schools were made to attend the normative school system in their respective community, or as the participants often put it, "we had to go up to the white school." For them, the abrupt closure of their schools was a source of trauma as it represented the negation of their cultural identity:

I think it hurt us in a lot of ways, maybe I'm wrong. They just moved us up there and we had nothing left you know, as far as having something left from our 
school. We had to go and step in their house, that's what I'm talking about - I sleep in their house, they took whatever they had, we didn't have anything left.

- Clara Smith, Born 1940 | Class of 1958 | Never Integrated

One man who integrated in the $9^{\text {th }}$ grade remembers he and his friends responding to this feeling negation by reasserting their belonging to the former colored school:

....and for us, we were mad because they closed our school down and we had the newer building, and they closed our school down. So we were forced to go to their building and stuff you know. So that part angered us too. All the stuff, it just got thrown away. I remember I was with some of my boys and we went and broke into the old colored school and we took some of the trophies and the basketball warm-up pants. There were four of us and we stole those and we would sport them [the pants] around and wear them. But yeah they just - they just did away with our stuff. So that was our anger in that.

- Albert Harris, Born 1950 in Benham, | Class of $1968 \mid$ Integrated in $9^{\text {th }}$ Grade

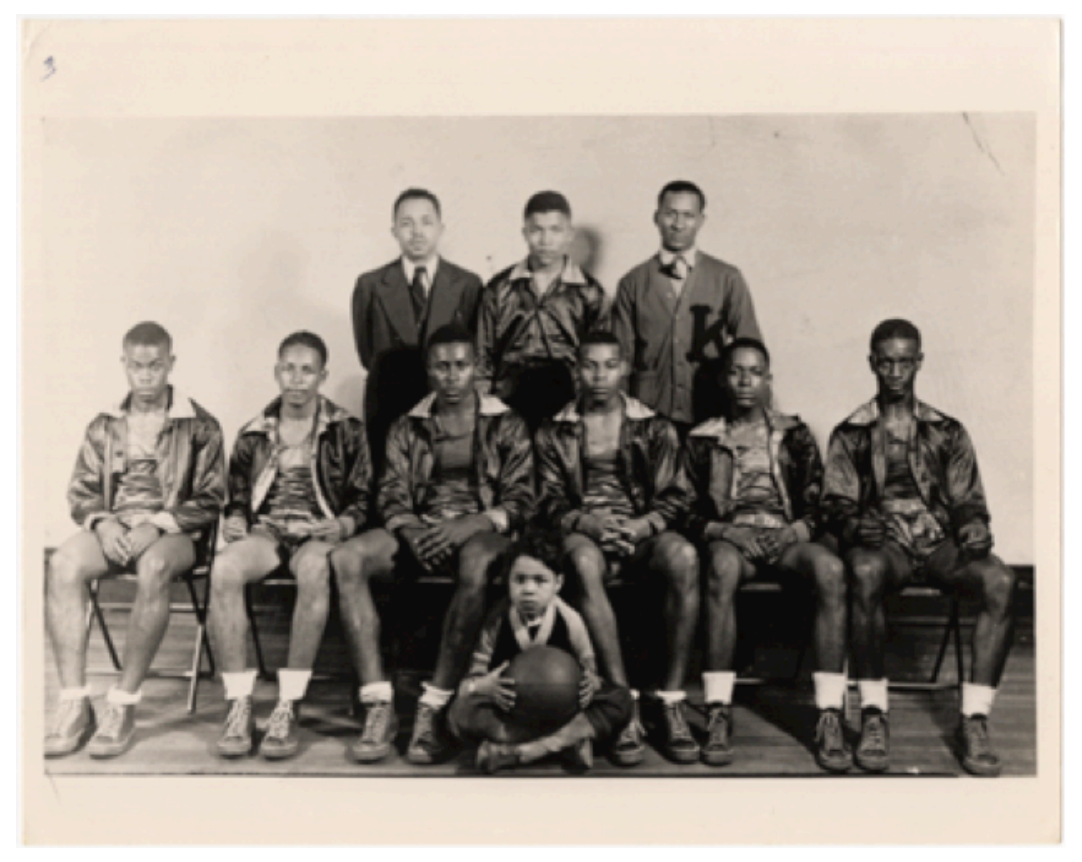

Figure 27. Lynch Colored School Basketball Team | circa 1950 
The feeling of loss extended to the community level. When pressed about the perceived cost of desegregation, participants consistently cited the loss of their teachers. The same respondent who reclaimed the basketball paraphernalia went on to link his sense of loss to the teachers:

...you got to realize that we had our own school so you had - from principal, assistant principal, math, biology, science, all the way down to the janitors. So the majority of them lost their jobs and it was the same way in Lynch, it was just a few teachers that maintained their jobs. So the rest of them had to leave the area.

- Albert Harris, Born 1950 in Benham, | Class of 1968 | Integrated in $9^{\text {th }}$ Grade

The elimination of the black faculty was by far the most cited perceived loss to the African American community. Living in a segregated community, isolated in the hollows of the Appalachian mountains, the teachers were intimately embedded into structures of the black community. Yes they were the children's esteemed educators, but they were also neighbors, family friends, Sunday-school teachers, and community organizers. Once desegregation was enforced, the black teachers were a redundant resource to the school system, and were, for the most part, let go. One participant, a woman who graduated high school in 1960, recalled the shock of coming home to Benham, Kentucky after graduating college to find that her role models were no longer there. "The teachers that I had all my life. They no longer had a job there. (Harriet Calloway Hillie | Class of 1959 | Never Integrated)"

These participants' statements shed light on the hidden injury: it was not the actual act of integration that generated negative feelings, it was the procedure in which 
the process was carried out. For them, it was not integration, but a habeas corpus in which their black bodies were called upon to move from a place where they had constructed a social world to one where they had no familiarity or advocacy. Although desegregation was challenging to everyone, no white children were put upon to uproot their surroundings and enter into another fully formed environment. Instead the blacks were mandated, in short order, to leave "their school" and all that came with it and adapt to a new surrounding. One participant sums up the feeling of such a process: The thing about integration is an acknowledgement that yours is better than mine, that I am inferior to you (John Steward | Class of 1958 | Never Integrated).

\section{Care by Teaching Staff}

The significance of the loss of the teachers cannot be underscored enough. Born one or two generations out of slavery, few black parents in Harlan County had more than an $8^{\text {th }}$ grade education. They therefore depended on the teachers to elevate their children into full citizenry through education. To that end, parents ascribed a tremendous level of trust, legitimacy and esteem to the college-educated teachers who were employed at the colored schools in Lynch and Benham, Kentucky, and the teachers, for the most part, accepted the mandate of racial uplift.

Thematically, interviewees' rich memories of their experience in the colored schools are framed in terms of strict disciplinary environments-laced with anecdotes of high teacher expectations in terms of academic performance, behavioral comportment, and physical hygiene — coupled with a strong feeling of care, intimacy and trust. 
...they're the definition of tough love with all of the positive trappings. While it would have been convenient and easy for them to say you can't do it and the world is unfair and say all those things, and then let us sort of bask in mediocrity--they went the other route. They were not going to let us do less than what our abilities would have us do. And so to earn a mark and having those kinds of expectations and projections in confidence were very, very influential in the successes and there are many, many successes that have come out of that community. But they were the catalysts for that; along with our parents.

--Jerome Ratchford, Born 1942 in Lynch, | Class of 1960 | Never Integrated

Everything was close and the teachers cared - truly cared about your education and they made sure that you concentrated on your education. Dot the I's, cross all the T's, and all that kind of stuff. And they constantly prepared you and they followed up with you, they had home visits to your parents, to let parents know how you were doing in school, if you're doing bad or good and what you need to.

Chuck Rodgers, Born 1957 in Lynch, | Class of 1974 | Integrated in $2^{\text {nd }}$ Grade

However, that social contract between the teachers, parents, and children was breached with school desegregation. When asked to reflect on the their memories about "going up to the white school", participants overwhelmingly pointed to a sense of loss of care. The short response that first came to mind for many respondents was that I didn't want to be there and they didn't want us there. When pushed to unpack what that meant, participants framed their responses in terms of teacher apathy:

Their teachers didn't seem to care about us like our own did. To me, it was sort of, "if you didn't get it you didn't get it". It was not like they were going to spend that one on one with you.

--Belinda Napier, Born 1951 in Cumberland, | Class of $1969 \mid$ Integrated in $7^{\text {th }}$ Grade

Their mentality was that "these black kids are here, we got to accept the fact that they are here, but I am not going out of my way to give them any extra help if they need it. I am just going to deal with it to the extent to which it is beneficial to the school." To me, that was their mentality. And I watched an observed a great deal of the teachers, because when I came in, it was nothing but all white teachers; that's all. 
-Jack French, Born 1945 in Lynch, | Class of $1964 \mid$ Integrated in $12^{\text {th }}$ Grade

To me, when we integrated it seemed like the teachers, the white teachers, they didn't care whether were learned or not. They were just there, and that was it.

- Shirl Baskin Brack, Born 1947 in Lynch, | Class of $1965 \mid$ Integrated in $11^{\text {th }}$ Grade

Their perception was that they were invisible to the teachers in the integrated school system. Sociological theorists of the self argue that the self is an amalgam of attitudes that society has towards the individual, wherein the response of others informs how the individual comes to recognize him or herself (Mead, 1964). In the colored school, black students received affirmative responses to their being, however, the mutual recognition necessary to generate a positive form of what Cooley (1992) called "self feeling" was absent upon integration.

\section{Transforming Racial Epistemologies}

Du Bois points to the 'thousand and one little actions' that he characterizes as both 'elusive' and 'essential' for the construction of social worlds. For him, the most detrimental outcome of Jim Crow was the psychological fissure between the white and black social world that thwarted each group's ability to see each other as equal. For many children, the integrated school was the first and only public sphere in which black and white children had the opportunity to share any meaningful social exchange. Therefore previous conceptions of one another were based primarily on myth as opposed to experience. The physical and social separation conditioned by Jim Crow engendered 
assumptions of white superiority and difference. However, for many, these notions of ontological difference were demystified with time and interaction.

...we had a background from the Black school, I honestly say this with all my heart; they gave us a foundation that learning was everything. So it didn't matter if I was in school with White people talking about me, I didn't care. But I wanted to know [pause] and I wanted to know what they meant. What made them so different to everybody else? ...We all thought White people were all well to do. All better off than we were. Well as time went on, we started running into people that didn't mind telling you how poor they were and the different things they had to deal with and their environment. And I began to see a different class of people among themselves - white people - especially freshmen in high school. There were people in there that didn't have it like the rest of the white people and they seemed to be attracted to the black people for some reason. But that was eye-opening moment for me because before, I wondered why white people didn't want to play with us [pause] because they thought they were better.

- Raveryn Whitt, Born 1955 in Benham, | Class of $1973 \mid$ Integrated in $6{ }^{\text {th }}$ Grade

And I tell you the funny thing about that, when we integrated, I was kind of afraid because, see, we always got the books that they had. They had sent us the leftovers... and when we integrated I was kind of nervous because I thought that we were not going to be prepared like the whites, but when I got out there it was totally different. I was surprised, we knew more than some of them!

- Shirl Baskin Brack, Born 1946| Class of $1965 \mid$ Integrated in $11^{\text {th }}$ Grade

The integrated environment occasioned the black students to question otherwise taken-for-granted notions of racial inferiority. While the segregated school system presupposed ontological racial difference between blacks and whites, the integrated system allowed for the possibility to think otherwise. Put differently, the possibility for the students in the integrated system to recognize themselves as children, instead of black children and white ones was a transformation in American imagination. In time, black and white children began to form friendships, particularly young school-age children who were not yet fully aware of the intangible veil of the color line. However, the social 
forces of racial prejudice were constantly at work to reinforce understandings of racial order. One participant shared a painful example of how a subtle act of bigotry awakened his racial consciousness at a young age:

Because the same kids we saw at school, their parents wouldn't let them run to us. We played at school, but then when we would see them at the store, we would see their parents hold them back as the were running towards us. Because what do kids do when they see each other?!

- Raveryn Whitt, Born 1955 in Benham, | Class of 1973 | Integrated in $6^{\text {th }}$ Grade

In this moment, both children were the victims of the white parent's racism.

Through that subtle encounter, and many others like it, the black child lost the privilege of just recognizing himself as a human, a child. Instead he came to understand that he was a black child, which meant that he was a different type of person than his white schoolmate. As for the white child, he or she was unfortunately on the receiving end of an intergenerational transmission of white supremacist ideology. In a Du Boisian formulation, this is an example of the awakening of "second-sight". As, Du Bois lays out in Souls of Black Folk, although second-sight allows the racialized subject to see social forces of the veil at work, it provides no solution to the subordinate condition of the African American subject. In this same way the participant in the example above, although conscious of the parent's motivation behind the restraint, could only internalize the reality of his social condition. While this awakening was not a source of trauma to the African American children of integration, it was a meaningful transformation that accompanied the process of desegregation.

Fear of Miscegenation 
Lastly, and very briefly, there was also a perception that the teachers and administrators had a strong, yet unstated, fear of miscegenation. The following anecdote shared by the first black homecoming queen best describes this perception:

Shirl: $\quad$ And then okay we were supposed to have a parade. At first the Principal and all of the said that they were not going to have a parade so basically the team was made up of almost all of the black athletes. So they decided that if they were not going to treat me the same way that they had treated the previous queens, then they were not going to play. So that was what you call where we were 'united', and I was the first. It was an experience.

Me: $\quad$ Did they have the parade?

Shirl: $\quad$ They had the parade... and they could not find the floats, so my uncle went all the way to Middleborough, Kentucky to get a float for me to ride on and it was a convertible car. And during the coronation, usually the football captain kissed the Queen. Well because the football captain was white they had the chairman of the school board to crown me. And that still makes me mad to this day.

The newly integrated black children at Lynch High School chose the selection of the homecoming queen as the first battleground for incorporation into the social fabric of their new environment. They threatened to revoke the one thing that they felt their white counterparts valued about them. Not their presence, their minds, their fashion and other forms of cultural expression. No. They threatened to take away the black male body from the athletic sphere. Typically constructed as something to be feared within the American white imaginary - the brute stealthily lurching through the streets looking to and fro for the next white woman to rape, the young boy frolicking through a neighbor's yard on his way to catch sand-doggies from Looney Creek, identified and hailed as a trespasser and a threat, conjuring the changing same "Hey Nigger!" within his white interpellator, the oaf, the boogey, the 
criminal-however, within the context of the desegregated school, young black men were to be loved and adored, not feared: because they were star Athletes! Nearing the end of the basketball season in 1965, when Lynch stood to win a State Championship, the mere threat of the black athletes not playing was enough to make a queen out of Shirl Baskin Brack.

\section{The Costs and Benefits of School Desegregation}

I asked my participants to reflect, sixty years after Brown v. Board, on their perceived costs and benefits of school desegregation. Responses varied, by generation and by level of abstraction. While acknowledging the benefits of desegregation, they all expressed some form of injury, a loss of community and African American identity. In addition to conducting oral history interviews with the African American children of integration for this study, I also made an attempt to interview the former black teachers from the colored schools in Benham and Lynch. Four of the eight living teachers identified were willing and able to participate in the study. Their reflections on the costs are most reflexive in articulating the tension between the perceived benefits and costs of school desegregation:

When they were talking about integration there were many people who were excited about it; our children can get a better education. Like, I remember this vividly, they can take chemistry so they can be nurses and doctors, and when they got an opportunity to take chemistry I went down there took chemistry voluntarily. But we lost - teachers had interest in children, they were black teachers. They wanted you to learn, they helped you, they worked closely with the home.

And when the children got into the white system, they were on their own. Not all teachers were like that now, there were some that pushed. But there were some who didn't. And the children just felt it and cried...and a lot of our exschool activities that we had we didn't have those anymore. And to me most emphasis was put on athletics--can that boy run, shoot that ball. They didn't remember those bright kids that came up there. 
-Clara Clements, Graduate of Lynch Colored, Class of 1955 | Former Teacher at Jenkins Colored School and Lynch High School (Integrated)

I know in Lynch we got hand me down books. The white school used the books and then we got them and we paid for all of our supplies; the teachers paid for them. When we integrated we got new books and we got - I got all the paper I wanted for typing - you know the reams of paper you print your exams and things on. Everything was paid for...But I think really that in the black school, black teachers understood the black kids and I think that made a difference with the black kids. When they integrated, some of those white teachers didn't know anything about the life and livelihood of black people. And I don't think they were as patient with them as the black teachers were.

--Vergie Mason, Born 1923 | Former Teacher at Lynch Colored Public School and Lynch High School (Integrated)

We lost and we gained...this is how we gained. I think that some of our children thought that they were inferior to whites and they found out that they knew more than a lot of them did. And then some of the whites thought that we were inferior and they found out that we knew more than what a lot of them did.

-Rose Ivory Pettygrue, Born 1937 Former Teacher at Lynch Colored Public School

The cost I think was the community...it dissolved and there was sort of an acclimation to people and we sort of lost our identity. The benefits were, I think, more psychological than anything. We learned that we were as good as and better than...

--Charles Price, Born 1933 Former Teacher and last Principle at Benham Colored School

Black parents and teachers alike recognized that school desegregation would broaden the horizon of opportunities for their children, opening up pathways that were nearly impossible within the segregated system. And the black teachers attest to the ways in which the integrated school system evened the playing field for black children to thrive in an integrated society. Consistent with the infamous black doll-white doll study presented by Drs. Kenneth and Mamie Clark during the Brown v. Board case, the 
teachers also noticed how the integrated setting helped attenuate black students' prenotions of racial inferiority.

However, the opportunity and access that school desegregation afforded came at a price. Few black teachers were hired into the integrated school system, and black students found themselves in a culturally precarious environment, where racial assumptions, fears, anxieties played out in their everyday interactions with their white teachers. While this process of misrecognition surely went in both directions, the power dynamic entangled with the teacher-student, white-black, adult-child relationship gave the white teachers the privilege to determine the nature of their interactions with students.

As with any process of social integration, those who experienced the transition at a younger age, in this case before high school, had an easier time acculturating into the new system. It was the high-school aged generation, those who integrated between the $9^{\text {th }}$ and $12^{\text {th }}$ grades, who shared the most visceral, negative, responses to questions related to school desegregation. At that age, they were much more self-aware of their status as second-class citizens and the material reality of racism. For them, school desegregation was wholly traumatic. The responses from the participants who never integrated, who represent fifty percent of the sample, had mixed reviews about whether of not they themselves would have liked to the opportunity to attend an integrated school system. Overall, almost all participants responded that they are glad that school desegregation happened, some just wish that it hadn't happened to them personally. These experiences based on age at the time of event are consistent with other accounts that document the psychological aftermath of integrating public school system (Diehl, 2007). However, as 
the spectrum of accounts ${ }^{16}$ presented in this chapter demonstrates, school desegregation marked a "watershed" moment that "a sense of before and after, that can shape what Mannheim referred to as generational consciousness (Eyerman 2011).”

\section{From "Hidden Injuries" to Cultural Trauma}

So how is this a cultural trauma? So far my analysis establishes that there was some form of individual trauma that this generation similarly experienced with school desegregation. However, the strong theory of cultural trauma requires not only that an event is collectively experienced as traumatic, but also that it is represented as such (Alexander et al., 2004; Eyerman, 2001). Carrier groups, such as scholars, media outlets, curators, archivists, politicians, and affinity groups, articulate representations of a cultural trauma into the public sphere - a meaning making process through which individual, or private traumatic experiences become collective, cultural traumas. For this group, it has taken over half a century for their hidden injuries to begin to materialize into the public sphere as a cultural trauma.

\section{Carrier Groups}

The three main carrier groups that have promulgated the emergence of this cultural trauma are individuals, community affinity groups, and the Eastern Kentucky African American Migration Project. As recent studies have shown, some cases of cultural trauma have limited reach beyond the "victim" group. This can be because the collective trauma is a racial memory, which Eyerman (2011, p. 46) points out "is distinct

\footnotetext{
${ }^{16}$ Quotes presented in this article range from those who never integrated (4), those who integrated earlier in their childhood from second through ninth grade (6), those on the front lines who integrated between tenth through twelfth grade (6), to former teachers at the colored schools (4),
} 
from and lives alongside a national, collective memory", and therefore has less appeal to the moral universal narrative of good and evil (Eyerman, 2011; Sitas, 2015). Other events struggle to emerge as cultural traumas because of the victim group's inability to assuredly identify the true perpetrator - the "they" who did this to "us" (Bartmanski \& Eyerman, 2011; Debs, 2013). A third explanation for why some cultural traumas fail to fully emerge, or are delayed for prolonged periods of time, is that the victim group does not yet have elite carriers who have access to the public sphere (Debs, 2013).

In the case of the children of integration from Harlan County, Kentucky, narratives of their hidden injuries first emerged into a cultural trauma within the African American community before it began to circulate into the broader public sphere. Everyday people who shared group membership with the community largely carried out this discursive process. In the early 2000's, after retiring from a long career with the United States Air Force, a graduate of the Lynch Colored Public School turned his attention to recovering the seemingly lost history of his "colored school". For over a decade Sam Howard Jr. combed the state and local archives as well as the personal records and photographs of friends and family to create an annals of the colored school. He distributed this nearly 200-page document to other community members who were once West Main "Pirates" and solicited contributions to add to the text. Below is an excerpt from the first page of the book entitled, Wanting to be Remembered: Lynch Colored Public/West Main High School, Lynch 1923-1963:

"History is defined, "a chronological record of events, as of the life or development of a people or institution." In this case, "The Lynch Colored Public/West Main High School, Lynch ." However and unfortunately, much of the school's history diminished with the departure of lives and memories with many of the faculty and students that taught and attended the school. And we all 
are, “Wanting to be remembered!" Not only the schools in Lynch, but it seems that documentation to support historical events of most all formerly Black schools in the state of (especially Harlan County) prior to integration, was not maintained. With this in mind, an all-out effort is being attempted to compile as much of our history as possible for the Lynch Colored Public/West Main High School, the all Black school (prior to 1963) and located in Lynch, ."

Over the years, fellow LCPS students have contributed to this text and updated versions continue to circulate amongst the black community. When I first began conducting oral history interviews for the larger research project, participants often introduced to this book as a key point of reference to "get the story right". During our interactions the text was not only referenced to prove their existence, but it was a medium that gave them validation and platform through which to express their hidden injuries. However, although this growing manuscript was widely circulated and discussed within the black community, it is rarely shared beyond it. This is largely because theirs was not a trauma of integration, but of erasure.

Other individual carriers such as class of 1964 Lynch High School graduate, sociologist William H. Turner (a member of "the first three" classes to integrate), have engaged in the "cultural trauma drama" in the academic sphere. In one of his academic publications (Turner, 1986) on Black Appalachia, he wrote:

"The individual Black schools that dotted the hills up through 1965 were the organic bases around which Black inter-community relationships evolved...More than any single factor, the dismantling of Black schools had the effect of removing the key institutionalized channels through which Black people in Harlan came together. The centrality of schools and the galvanizing effect of the institutions in Black Harlan society--and the consequences in Black society of their elimination--is not too unlike the significance of tradition-bound religious institutions described by Achebe (1959).

For decades to come Turner and other public figures articulated the impact of the closure of black schools on the dislocation of the African American community. However, as the 
first generation of African Americans to benefit from the access into mainstream academic field, there were few "carriers" of his kind to articulate the cultural trauma narrative into the public sphere.

I must also include myself, as a second-generation descendant of the children of integration and cultural sociologist, I have contributed to the "cultural trauma drama" by narrating the trauma and by facilitating access to new public mediums for this generation to share their experience with a broader audience through my efforts with the Eastern Kentucky African American Migration Project, media outlets such as public radio stations, and public exhibitions. The last, and most significant material expression of the cultural trauma of school desegregation is the Lynch Colored School building itself.

\section{A Lieu de Memoir}

The Lynch Colored Public School, built on the most western parcel of land in the city of Lynch, , closed its doors in 1963, after city officials reluctantly made the decision to desegregate the school system. Although it graduated its last class over fifty years ago, the building still stands—-with the buxom "Colored" wording reverently etched in stone - and is owned and preserved by a group of African Americans who once matriculated through this school. For them, this building serves not only as a place of activity, for social gatherings and meetings, but also as what Pierre Nora (1989b) calls a "lieu de memoire"; a site of memory "where memory crystalizes and secretes itself." It is the "embodiment of memory" where "a sense of historical continuity persists", and where the collective identity of the black children of integration rests. 


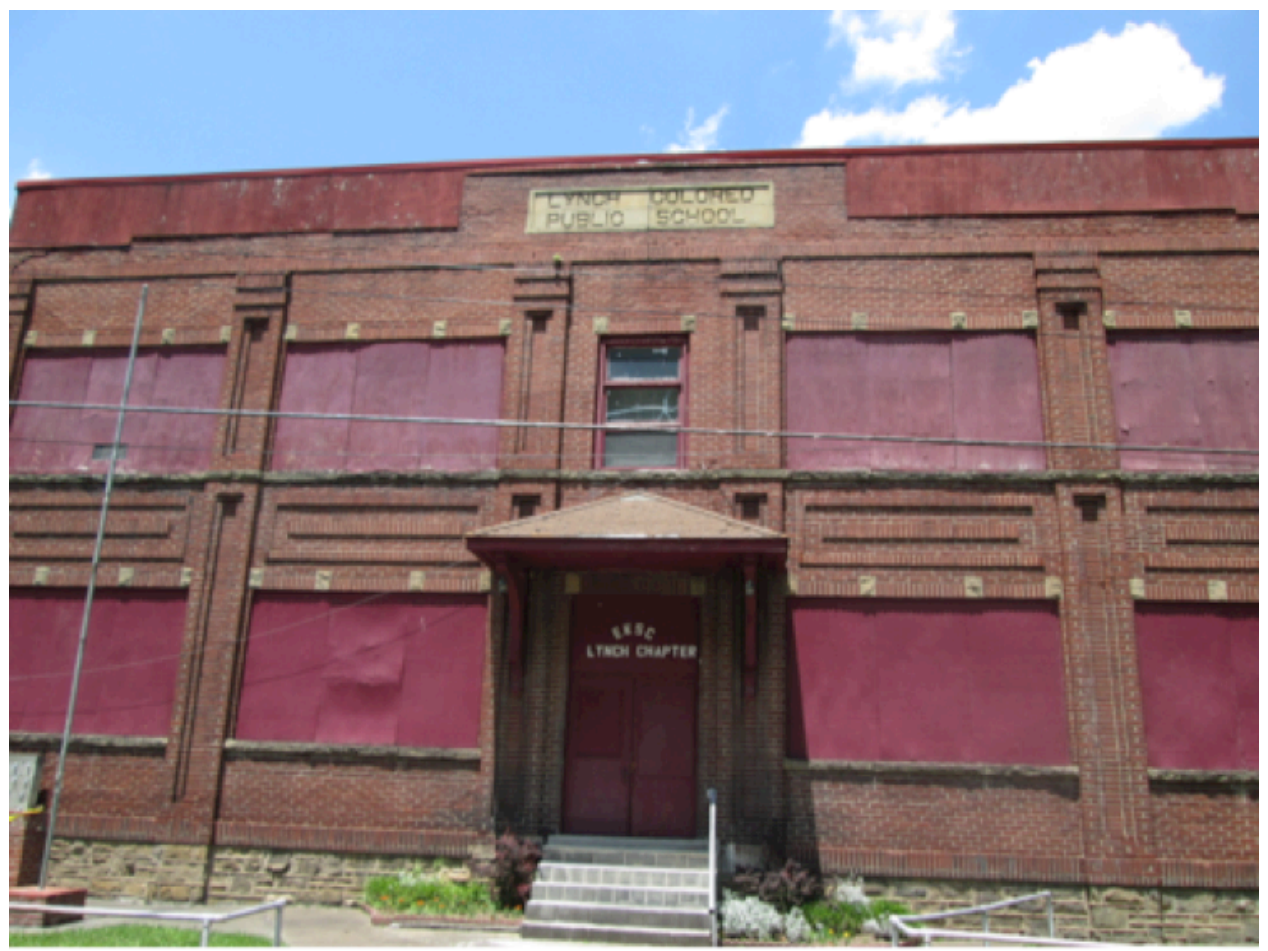

Figure 28. Lynch Colored Public School Building | 2014

One of the central tenets of cultural trauma theory is that no event is inherently traumatic, but instead must be constructed as such through collective representations of the trauma (Alexander et al., 2004). The African Americans who matriculated through the colored schools in this region ensured that the Lynch Colored Public School building continues to stand as a site of memory and as a representation of their collective identity. In 1972, the Eastern Kentucky Social Club — a social organization comprised of African American migrants from the coal towns southeastern Kentucky_-purchased the building, and it is currently used to host social functions for its members. More strikingly, it stands as a site of memory to honor their history and culture as black Appalachians.

Painted on the front and back doors are signs that say "EKSC: Lynch Chapter" and "Property of the EKSC: Members Only". Standing metal plaques commemorating their teachers adorn all corners of the building and the side street leading to the building's 
parking lot has been renamed "John V. Coleman Way" in honor of the last sitting principle. Individuals purchase bricks inscribed with the names of loved ones who have passed on to be inlaid onto the western corner of the building. And to bring the space alive, the African American migrants who grew up in this community return to Benham and Lynch every Memorial Day weekend to commemorate their heritage. The annual social gathering is always held in "their school".

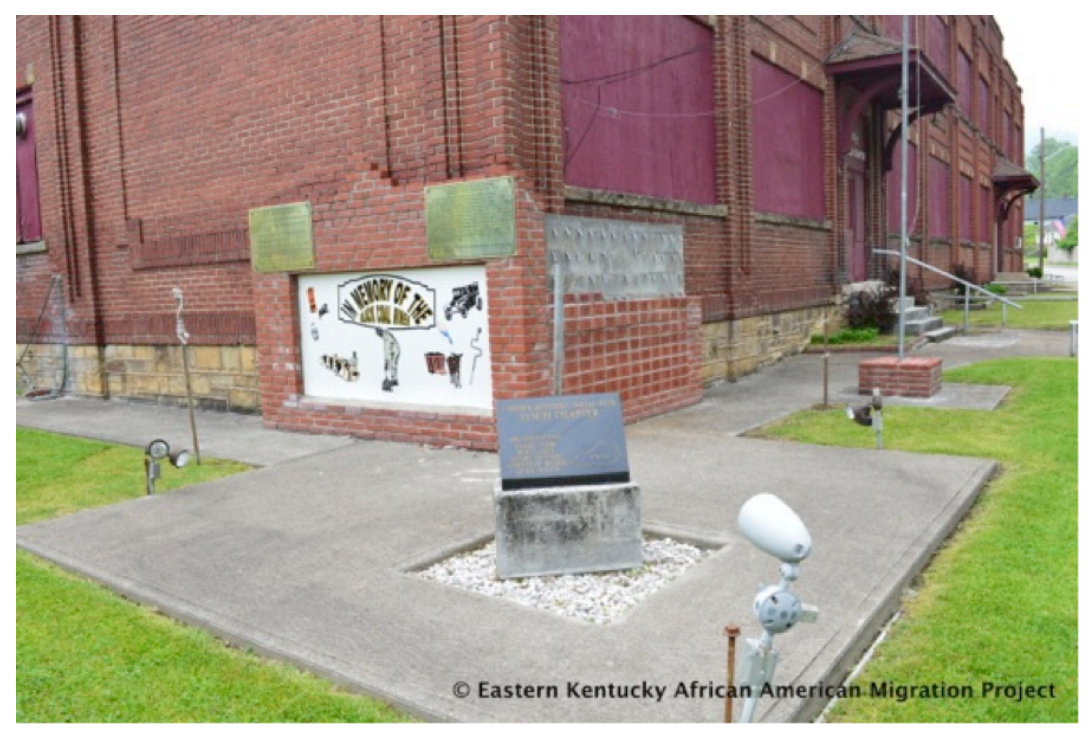

Figure 29. Lynch Colored Public School, West corner of the building | 2014

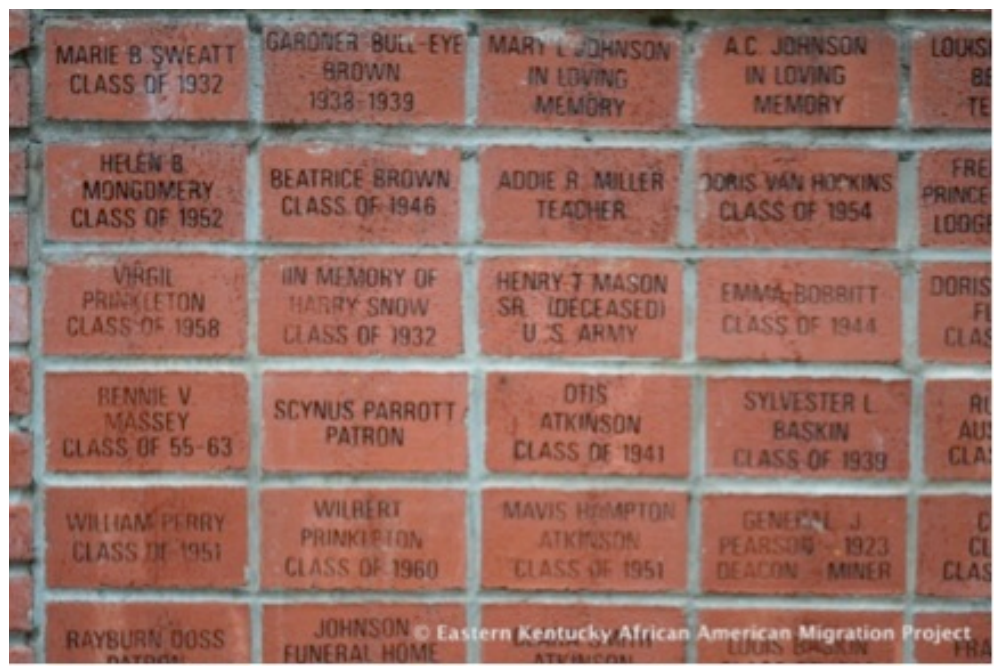

[Figure 30. Lynch Colored School, Memorial bricks on west corner | 2014] 
As Nora (1989) argues, "lieu de memoire are created by a play of memory and history". Far from a random occurrence, related groups intentionally construct lieu de memoire because they have a "will to remember" that site, moment, or experience—in other words it must be deemed memory worthy by the community. The blacks from Harlan County preserve this building as the rest of the community deteriorates, and they continue to re-appropriate meaning to this site through practice and commemorative objectification. It is too limiting to frame desegregation as an institutional transfer, or a mere opportunity for blacks to enter 'mainstream' society. It was a transformation in African American subjectivity and, in this context, a cultural trauma that left an indelible mark on the collective identity of the black community. One participant drove this point home in the following statement:

If you look up there right there today in concrete it says Lynch Colored School...Its right there today. It's written out there: Lynch Colored School. See because we went through a transformation as to who we were. We went from Colored, to Negroes, to African-Americans....and Black. We went through all of those.

-Albert Harris, Born 1950 | 1968

Surely on both sides, this encounter brought to fore feelings of inferiority and superiority, difference, curiosity, and discomfort on the part of students and parents in these communities. However, the African Americans faced material dislocations in their cultural and economic structures, due to the abrupt closing of their schools, and subsequent job loss of their beloved teachers. This event had lasting effects on their perception of their identity and sense of belonging; to the extent that the blacks from this area have purchased the "colored" school building and preserved it at an eternal testament that "We were here": a quotidian, yet powerful assertion of being in the face of 
erasure.

In the end, most of the interviewees expressed that the benefits of desegregation were undeniable and they are glad that it occurred. However, most eloquently stated by Clara Clements, one of the few living teachers from the Lynch Colored School— "We gained what we wanted but we lost what we had."

\section{Discussion}

In this chapter, I argued that a hidden injury underlies the landmark Brown vs. Board decision that led to the desegregation of the U.S. public school system. Using a combination of oral history data from the Eastern Kentucky African American Migration Project (EKAAMP) collection at the Southern Historical Collection at UNC Chapel Hill, documentary and photographic archival data, and site observation of a lieu de memoir, I demonstrate how the event of school desegregation was constructed as a cultural trauma for a group of African Americans who grew up in segregated communities in eastern Kentucky during the Civil Rights era. In addition to adding another case to the growing body of cultural trauma literature, this study contributes to cultural trauma theory in two ways.

First, it illuminates the ways in which race and racialization complicate the emergence of a cultural trauma into the public sphere. This is a product of the dialectic relationship between the social force of racial projects (Omi \& Winant 1986) and the subjective experience of racialization (Du Bois 1903; Du Bois 1940). Twoness, or the tension between ones ethnoracial and national identity is one of the defining elements of racialized subjectivity; Du Bois (1903) describes the internal struggle with twoness as the feeling of having "two souls, two thoughts, two unreconciled strivings; two warring 
ideals in one dark body". School desegregation generated this tension within the African American community as it simultaneously affirmed their "Americaness" and denied them mutual recognition of their ethnoracial identity. In this way, the trauma underlying the event of school desegregation was experienced as a trauma of erasure. This feeling was not instantiated by the event itself, but by the process - the closure of the black schools, the abrupt loss of the black teachers, and the sense of social isolation within the white school. In speaking of the sometimes contradictory relationship between the fact of events and the experience of collective trauma Kai Erickson (1995) reminds us that "it is how people react to them rather than what they are that give events whatever traumatic quality they can be said to have".

These "racial memories" (Eyerman 2011) run parallel to the national narrative of progress embedded in the landmark Brown vs. Board decision, a decision that interpellates American identity--an emblem of "who we are"--that hails American citizens across ethnoracial dimensions. In this way, the narrative of injury and trauma appears to contradict what is championed as one of the greatest signals of progress for African American civil rights. Therefore we see the cultural trauma of school desegregation emerging out of "hidden transcripts" of the children of integration, and circulated internally where the narrative would receive the affirmation and mutual recognition.

This study also takes into question the characterization of carrier groups. If the function of the carrier group is to articulate the cultural trauma into the public sphere, how can an event be simultaneously a hidden injury and a cultural trauma? What this case shows is that in instances of hidden injuries, where a universal narrative of progress 
overshadows the shared traumatic experience of a particular group, cultural traumas can be constructed and circulated within the margins and hidden in plain sight. In these cases, carrier groups needn't possess an elite status that would afford them access to the public sphere. They instead would only need enough within-group social capital for the trauma narrative to gain legitimacy and be accepted and representative as traumatic. In this way, non-elite community members, such as Sam Howard Jr., are just as much carriers of the cultural trauma as "elite" actors such as Dr. Turner, EKAAMP or myself. This expansion the characterization of the carrier adds a greater level of dimensionality to the field in which we observe the formation of cultural trauma.

\section{Conclusion}

The United States just celebrated the 60-year anniversary of the Brown vs. Board of Education decision - the most progressive legal feat of the twentieth century. Along with laudatory media coverage honoring the accomplishment and the great struggle that many Civil Rights leaders and communities endured to make it happen, there was also an outpour of African Americans who urged us not to forget the value that they placed on their colored schools and to acknowledge the sacrifice made for the higher goal of integration (Bates 2014). Clearly the implications of the social transformation that resulted from this 'eventful temporality' loom large in the American conscious. However, the sociological inquiry into the cultural and psychosocial effects of school desegregation remains understudied.

This chapter offers a brief insight into the lived experience of school desegregation from the perspective of African Americans who experienced the process in 
a localized context. There are a variety of ways in which this process played out on the ground in different communities, however the research consistently shows that African Americans valued something about their segregated school systems (Mungo, 2013;

Schircliffe, 2001; Walker, 1996). This recent history offers a rich, untapped, site into the study of African American identity and culture as well as the study of racial (trans)formations.

African American educational attainment in this country is highly mediated by the social fact of racial segregation-historical and contemporary, de facto and de jure. To understand contemporary outcomes in the educational attainment and behaviors of African Americans in this country is to understand the historical conditions under which the American education system was structured and transformed along dimensions of race, region, sex, and religious affiliation. And surely other intersections apply that are worthy of careful investigation. The event of school desegregation is a site of transformation in African American identity and citizenship: where as a people, as Albert Harris tells us in the opening epigraph, "they went from colored, to Negro, to black, to African American." 


\title{
CHAPTER SIX
}

\section{Gone Home: Race and Roots through Appalachia}

If you're born in Kentucky you've got three choices: coal mine, moonshine or move it on down the line.

-- Lee Dollarhide | (in the movie) Coalminers' Daughter

\begin{abstract}
And there is a bond, there is a bond that ties us all together to that little coal-mining town in Lynch, Kentucky, and we feel like we are one and the same. No one was better than the other so it's like a little piece of heaven. --Katie Sue Reynolds Parks | (a real) Coal Miner's Daughter | Born in Lynch,
\end{abstract}

\section{Introduction}

They had been preparing for this their entire lives. Lynch was home. Benham was home. Cumberland was home. Deep down, however, they knew it never really was theirs. Comprised of centuries of lives and generations and peoples and cultures and tongues and feuds and spilled blood, the generation of black children who grew up in those Kentucky mountains were a mere sheet of parchment in the thick palimpsest that is this land. From the indigenous peoples who girded their loins as they bore witness to their own genocide, refusing to leave their land, dead or alive, to their perpetrators, the Scots-Irish frontiersmen who began settling in the Cumberland Plateau beginning in the $17^{\text {th }}$ century, to King Coal, the paternalistic industry that brought in its own population of European immigrants and Southern black refugees, transforming that same "native" white frontiersman into the invisible and culturally extinct hillbilly, to nature, who is now reclaiming the land that was always her own: in this way, Appalachia belongs to no one. 
By the mid-1940s, coal mining had begun to transition from a labor-intensive to a machine intensive industry. International Harvester Corporation and U.S. Steel no longer invested in bodies, but instead in machinery and technology. The companies adopted new strategies to control their labor population, including systematic layoffs, hiring freezes, and imposing certification requirements on certain jobs to create "areas of expertise". Through this process of mechanization, the black population stood witnesses to their own erasure. Laborers were expelled from Harlan County in the same way they were recruited; by a judicious mixture of race and ethnicity. It is no surprise that the black body was the most expendable to the company. Suddenly cut out of the labor economy, black working-age adults found themselves with no job opportunities in sight. Earl Turner worked in the mines in Lynch for fifty-five years before retiring. One of the first black mine foremen in Harlan County, and a veteran United Mine Workers of America member, Turner braced his children to dream of another world. His son Jeff was a young child when the industry transitioned:

\begin{abstract}
Absolutely we saw it because our fathers were telling us what was going to happen and what my father said was going to happen has happened, because nobody black got jobs any longer...Before the mechanization of the industry, coal mining was definitely in your blood, it was in your blood. What the mechanization of the industry did was it eliminated jobs. It eliminated jobs because mechanization increased tonnage... but when they brought in those big machines to Lynch; I will never forget that as a little boy when they brought the machines in...
\end{abstract}

Where the pick and shovel symbolized the miner in all his necessity, the machine symbolized his superfluity. As a community they braced themselves, albeit unconsciously, for the ruination to begin. Black teachers warned their students that they needed to get an education because there would not be jobs in the mines for them when they came of age, fathers eschewed the idea of their children even thinking about following in their 
footsteps, mothers told their children that "you better get you an education." No matter what, it would not be an option for this generation to stay in the place that they called home.

Concomitantly, at the macro level, the demographic landscape of the U.S. was changing dramatically. The period between 1940 and 1970 marked the "second wave" of the African American Great Migration. Whereas a little less than two million blacks migrated from the South to the North during the three decades prior, another five million migrants poured out of the South during the second wave. Although the geographic thruways were very similar to those established during the first wave of the Great Migration - migrating from states in the Deep South such as Alabama, Mississippi, Georgia and Alabama to resettle in Chicago, Detroit, Philadelphia, Cleveland, Los Angeles and New York - the second iteration of this outpour took place on a very different social, political and economic landscape.

First, unlike the earlier migrants, the second wavers had access to information and support from established migrant networks; they were more like to know family, friends or fellow homefolks in potential urban destinations. As a result, second generation migrants had a virtual blueprint on which to map their own migratory pathways. Second, the racial political landscape was in-flux by the 1940 s, and would undergo a transformation over the course of the decades to follow. By this time blacks across the country, in the South and in the North, had established a assemblage of cultural centers, institutions, organizations, rhetoric, and practices that supported the needs and interests of negroes in America. Organizations such as the NAACP, the black church, black Freemasons and the Eastern Stars are all examples of black social organizations that had 
flourished in the early $20^{\text {th }}$ century and thrived through the decades. In addition, information about the conditions of black life throughout the country circulated at a much greater force due to black newspapers such as the Crisis. The emergence of this interconnected system of personal and institutional networks created the infrastructure for what would later become the Civil Rights Movement. This network was also the vehicle that mobilized the black migration out of Harlan County, Kentucky.

In a single generation, these black coalminers' children engaged in a communitylevel ritual in which, within a few days of graduating from high school, they received a one-way ticket out of town and resettled in a new destination in an urban location outside of Appalachia. This out-migration took place over the course of a thirty-year period, beginning shortly after World War II, and was facilitated by a well-oiled migratory network system. Older siblings came home on Graduation Day to pick up their younger siblings and bring them along with them to Cleveland, New York, Chicago, or Detroit to help them get on their feet. The Air Force and Marines was a conduit for young men to make it out West, and once their completed their military duties, many of them settled throughout California and Texas. In an entrepreneurial moment, one former community member went so far as to set up a boarding house in a Milwaukee, Wisconsin solely for the purpose of renting rooms to newly arriving Harlan County kinfolk to stay for a few months until they could establish a place of their own in their new city. By 1970, Harlan County lost seventy percent of its African American population.

\section{Country Cosmopolitan}


The black community groomed them for this migration from childhood. Although they were geographically isolated, light-years away from the pace and culture of the American city, living in the hollows of the Appalachian mountains-insular communities with one-lane roads, one radio station, four television channels, and movie theaters that trafficked in out-of-date B-Westerns; they were incredibly networked people. This is because they were forerunners of the African American Great Migration. The men and women who originally journeyed to eastern Kentucky from Alabama were among the first wave of the Great Migration. When they escaped Alabama, they often went alone, leaving behind their family and community in search of a better life. However, as decades passed, many of their siblings, cousins and friends who had initially remained in the Deep South also partook in the mass exodus to the North. While some remained due to choice, many had stayed in the South up until that point due to other factors such as fear, coercion, economic constraints, and family responsibilities. With the Great Migration in full force by the 1950s, the pathways to the major metropolises of the U.S. were clear. Therefore these family members, those who initially stayed behind in Alabama, tended to migrate directly to the urban centers in the North as opposed to layover destinations such as Central Appalachia. Because black families in Harlan County now had such expansive networks — both in the South and the North—parents made sure that their children travelled, and were exposed to the world that awaited them.

...even though we were isolated in this little one-horse town in Lynch, Kentucky, in the middle of nowhere, most of everybody had somebody that had previously migrated. And so over spring break and summer, you went and visited those siblings or whoever. And we brought back all the fashion of that time, from the Detroit's the Cleveland's the Chicago's....(Jerome Ratchford) No, because I had been exposed to the big city. New 
York, Chicago - so I didn't want to stay there. So when I left, I went to Chicago with my aunt. (Betty Williams) And we got our exposure to the city, how we got to these cities was through our siblings living the mountains before us. And since I'm the youngest of eight, I have seven brothers and sisters who left the mountains before I did. I attribute that to how I got out of the mountains and got an education because I followed my brother's footsteps. (Jeff Turner)... and they were the underground railroad to get us on our feet. Verla and Norma went first, and dad took us into Cincinnati for vacation, and Auntie Ruth lived in Cleveland, and then in Detroit there was Uncle Charlie and Auntie Lou. So we had our family connection all the way up. (Arnita Davis Brown) Yes, I went to Long Island when I was a sophomore in high school. I wanted to go there and work in the summer, so that I could buy myself some clothes for school. We were all getting ready to go to high school, you want to at least have three or four changes of clothes. But my parents could not afford to buy all those clothes. So I would work and that is how I went there. I went there in the sophomore year, junior year and in the senior year. (Richard Brown) It was a desire on the part of our parents and I applaud them for having a vision - that they wanted us to know about the world outside of the confines of the big Black Mountain...And we had older brothers and sisters, many of us. Our uncles and aunts who were in Philadelphia, Detroit, Cleveland and Chicago; you would go and they would open their house and you would live with them that summer with the understanding that you were going to get a job, you were going to work, you were going to save money...(Porter G. Peeples)

\section{$* * *$ \\ Participating in these rituals of visiting extended family in the big cites and} witnessing siblings and friends "move it on down the line" instilled a tacit understanding within these children that they too would migrate. Not only did their early experiences in these urban environments shape their individual worldviews, they also impacted the larger community back home in the hills. After a summer of working and vacationing, kids would bring back urban culture - the dances, the slang, the fashion, as well as the dreams and aspirations for something more.

...that's how come we loved dancing so much because once I got to Cleveland they taught us how to hand-dance. My boy cousins would take us to those parties. And the Cleveland hand-dance was different from anybody else'syou're pushing and holding hands - I still know how to do the Cleveland dance because of my cousin Wayne used to take us to parties... what we did during the summers even if it was two or three events you had so much fun, you had to come back home and share that with the country people in Lynch because you 
had something new to bring back. And then they go and buy us all this little new outfits for the first couple of weeks of school. So yes, going away to your older sisters and brothers and coming back was more than rewarding.

--Arnita Brown Davis | Born 1954 in Lynch, | Resides in Atlanta, GA

Through this process of exposure and cultural transmission, these mountain kids became country cosmopolitan. Although the Tri-Cities area might have been behind the times in terms of popular culture and modern living, the black community downloaded new iterations of black cultural expression from the cities and incorporated them into their own way of being back home. It also impacted the way in which they imagined their futures; instead of dreaming of reproducing their parents' lives, this next generation's aspirations lay in the as-yet possibilities of the city.

\section{Move it on Down the Line...}

Home transformed into a reference point in the life course the day after high school graduation. Between the combination of local push factors—father's forbidding their children from aspiring to become miners, teachers warning pupils that there wouldn't be anything there for them in Harlan County, the mechanization of the coalmining industry, and the subsequent forced attenuation of the labor force- and the broader socioeconomic pull factors — extended family and community networks, the call of the military, new industrial booms in urban centers, cultural transmission and exposure to the city, and of course the momentum from the social force that was the African American Great Migration. With all of this in the mix, notion that they were people on the move was a given. 
From my standpoint, graduating in 1964, it was not even talked about. It was like a creed in other societies-you left home when you got eighteen and finished high school. It was never said, it was never told to you. It was an expectation, like a kid in a tribe when you reach sixteen you become a man, like a bird leaving a nest. When you finished high school, it was time to fly.

- Melvin Duncan | Born 1946 in Lynch, | Resides in Charlotte, NC

I never had a second thought. I never thought about staying. Why?! There was nothing there for me as a woman, unless I chose to marry another coal miner. Women were not allowed in the mines. But as I recall, you automatically knew that at high school graduation that you were leaving. Did mother and father ever say that you were leaving? No. But you just knew. It was automatic. On graduation day the sisters and brothers that had already left and were in Ohio, or wherever they were, they came back on graduation day. And. We. Left. With. Them. Maybe even the next day! You were in the car and you were riding to Cleveland with an aunt or an older sister or brother and you were gone.

--Wanda Davis | Born 1957 in Lynch, | Resides in Cleveland, OH

Well, you know that was never a decision. It was pretty much understood in Kentucky that when you graduate- as a child your parents and the community's responsibility is to get you to adulthood and adulthood was expressed by your graduating from high school. When you graduated from high school, you were expected to not be in town the following Monday. If you were in town the following Monday then resources had been wasted to train and develop you, because you were supposed to be gone out to establish yourself and get a job and to become a contributing member of society and hopefully send something back home. But no I don't think that was ever and expectation that you would graduate from high school and stay.

--John Steward | Born 1942 in Benham, | Resides in Alisa Viejo, CA

\section{Chain, Chain, Chain...}

High school graduation was the defining moment of transition in every students'

life. It was not a question of whether or not they would stay or go, it was more so a matter where would they go and what they would do. All of the classical mechanisms of massmigration were at play to facilitate this out-migration. At the family level, chain 
migration was the primary way in which individuals accomplished their first move. Chain migration is a process through with family and friends from one's community of origin assists with migration and resettlement, usually in the form of indirect support, such as housing, food, job referrals, and information.

Leona and Major Brown raised sixteen children in Lynch, Kentucky. Like most parents, they were adamant that their children leave home after high school graduation. The Brown family profile is exemplar of how the chain migration process unfolded for many black families in Harlan County. Richard, the tenth of Leona and Major's children, recalls how he and his siblings ended up resettling in Long Island, New York.

Well, it started with my sister Johnetta. I think Johnetta was the first to go to do domestic work and right after my sister Vickie came. She did the same thing with the domestic work. And then my sister Shirley came. And then my sister Charlene came. And then we all--me and my sisters--had rented this house. First of my sister Johnetta lived in this room in the house and there were a few rooms available. So my sisters came and each one of them rented the room. So my brother came and he lived in there in the house with them. He got a job at a factory and a couple of years after that, my brother, who lived in Cleveland came to New York and he got a job in the same factory as my brother and then after that, he got a job at the Patterson nursing home where my sisters were working. And, it just went on and then after my brother came, my sister Mary came to live there for a while. So, then after that me and my sister Charlene came to live there permanently. And we all stayed in the same house and we rented the house and it had four bedrooms in the house, plus the kitchen and living room.

--Richard Brown | Born 1947 in Lynch, | Resides in Atlanta, GA

One by one the Brown siblings visited New York from Lynch and eventually relocated to Long Island until fourteen of the sixteen siblings resettled there. One of the youngest Brown siblings, Linda Faye resisted the idea of moving, and secretly planned to stay 
home after graduation. However, Leona and Major were not having it. She remembers her mother intervening:

She had my bags packed, had two garbage bags full of my clothes, a bucket of food, I said "I am not going", I cried and I cried and she said "yes you are!" I got up that morning daddy said "you're going." I didn't want to go. I am grown now, think about it, I am grown. And next thing you know I am at Eastern Kentucky University-they drove me to school. She had planned everything, she did it all for me.

--Linda Faye Brown | Born 1953 in Lynch, | Resides in Lynch, Kentucky

Although Linda Faye eventually ended up returning to Lynch, she did attend college for a few years before making that decision. What the Brown family illuminates is the way in which chain migration worked at the family level. Siblings supported each other not only with housing and material support, but also with making connections in their new environment—including facilitating relationships with employers, religious institutions, and new friends. They also demonstrate the urgency and durability of these family networks in facilitating a way out of Harlan County; one that was sustainable and without the economic and social shocks that can come with starting anew.

\section{Paths More and More Travelled}

Institutions had an important impact on the geographic diversity of the migration. While chain migration was by far the common migration mechanism, thus overdetermining intra-family migration patterns, the military, higher education, and marriage created alternative pathways for Kentucky's coal camp blacks.

In 1948, President Harry Truman signed, integrated the U.S. military through Executive Order 9981. Although blacks were always in the military, volunteering to join 
in an integrated context symbolized a new type of citizenship (Yęmisi \& Hamlin, 2015). In this pre-Brown, pre-Civil Rights Movement era, the military was one of the only public spheres that was expressly principled, in word at least, on racial equality; signaling the possibility of attaining the status of "American citizen" as opposed to the stateless "Negro". However, the spectre of Jim Crow still haunted the hearts and minds of military officials, so much so that not even orders from the President of the United States could break the mental stronghold of racial prejudice. Odell Moss remembers joining the Air Force shortly after the order had been issued. "President Truman had just signed the bill to integrate the military. It was integrated alright but segregation was still being practiced." (Odell Moss $\mid$ Benham) Blacks continued to be excluded from the full range of military ranks and positions, still had to eat separately from their white counterparts, and, as always, subject to the caprice of racism from any white person who felt like exerting it at any given moment.

One way that they could loose themselves from the tight grip of the veil was through sports, as the trope of the athletic "Negro" provided some sense of sanctuary. The black male body was well received as a source of entertainment, and young men were happy to offer it in exchange for being sent to the front lines of war. Both Korean War veterans, Odell Moss and Gene Austin both took advantage of this path. Moss recalls, "I was shipped overseas to the Far East and in the process I went out for the track team overseas - and I was rather fast, I admit that, and I went to the Far East Air force track team in a place called Nagoya, Japan." While Moss tried out for the Air Force track team, Austin was recruited to the military solely for his athletic abilities. He said that the "[Korean] war broke out and they were trying to get volunteers to go serve. So we came 
up there and you know, one day we were playing basketball somewhere and some soldiers come around looking at us. The marine said "you look like a good athlete" you know, he said "so how would you like to go in the military and play basketball with us?" I said "huh, you heard well". He said that he'd get me to serve and play basketball, so I volunteered right there. (Gene Austin $\mid$ Lynch)

Through the 1940s and 50s, there were two gendered pathways for working aged blacks to take - women could migrate to a city with a sibling or family member and find employment, or do so with a husband to start a family. My own mother chose the latter option. While nine of her ten siblings migrated from Lynch to resettle in Cleveland, Ohio, she chose a different path. Reflecting on her decision process she revealed that her reason for breaking the chain was "marriage, being in love, wanting a family, having education and being able to get more opportunities...It was the commitment to a man that I loved. So that really is the primary reason I was in New York." Men on the other had the choice of following the pre-carved path of a chain migration, joining the military voluntarily, or being drafted.

However, Southeast Community College presented a "cultural disruption", what Trondman et. al. describe as "a piercing of consciousness" that allows otherwise subordinated or marginalized groups to "believe or aspire to new possibilities." It was not that higher education was not an option for black high school graduates all along, as their teachers were examples of black people with such degrees, yet the pathway to college was unclear to these black youth, as there were no clear examples amongst their peers. However, when the local community college opened in 1960 - the first integrated educational institution in Harlan County,-its first class consisted of seventeen students, 
ten white and seven black. One of the members of that first class, Jerome Ratchford,

reflects on this watershed moment:

we didn't have choices when we graduated from high school. So it was either, try to find a job or go to the military. So I was so hell bent on going to the military, but thankfully, being young, being sixteen; my parents vetoed that. So I went sort of as an alternative to the university - but it only took me about one semester to say, "I like this, this is a good fit for me." So once that took place we were able to symbolize possibilities for those who followed and like I said, the rest is history.

--Jerome Ratchford | Born 1942 in Lynch, | Resides in Atlanta, GA

Quoting Trondman et. al. again, these seven students became "cultural resources", defined as "figures who become an example to what others can do and shows the pathway to incorporation" to the many that would come after them. Witnessing Jerome and his fellow black classmates succeed at attaining an associates degree from Southeast Community College and then to see some of those students move on to the elite, formally all-white state flagship institution - the University of Kentucky-exposed a whole new world of dreams to which younger cohorts would aspire. Speaking of the impact of having a local college in the eastern Kentucky region, Ratchford asserts that:

...it gave choices from a lifestyle perspective. You could entertain along with getting a job, going to the military; you could entertain going to higher education. And you could do it at a reasonable cost. You also had the opportunity to impact the lifestyle that you wanted for yourself. As the successes occurred amongst my colleagues and myself, people realized that they could choose to emulate what we did from a major perspective, from a career perspective or they could deviate from it. So they had more choices in terms of the types of lifestyles; career lifestyles that they wanted to embark on and so forth. It opened up opportunities, career opportunities and prosperity that we never could have imagined. So it was a very, very important institution. 
The symbolic barrier that those students from the class of 1960 broke, and as a result, the choices for black high school graduates expanded from two, to three. College became an aspiration for many, and a no-brainer for some.

Well, I was not going to stay there. Years before then I knew I was going to leave and I knew I was going to go to school someplace but I didn't know exactly where.

--Virginia Ward | Born 1949 in Cumberland, | Graduated Cumberland High School '67 | Resides in Dayton, OH

Well, you had three choices as my daddy said. Get a job, go in the army or go to college. When you reach eighteen and you're in the town of Lynch, Kentucky there was not many choices. By age eighteen I had the privilege personally to visit multiple cities because I have lots of brothers and sisters ahead of me. I had been to the University of Notre Dame to watch my brother Tony. I have been to the University of Notre Dame just to visit my brother, Bill. I have been to Fisk University to visit my brother Karl. I have been to Vassar University to watch is wife graduate.

--Jeff Turner | Born 1959 in Lynch, | Graduated Lynch High School in "77 |

Resides in Indianapolis, IN

I knew I was going to college, okay. Because my dad and my parents always told me "boy you aren't working in the coal mine, you're going to school." So I knew that I was going to school somewhere. So I started out at Southeast and then transferred to the University of Kentucky because I knew I was going to school somewhere.

--Lee Arthur Jackson | Born 1950 in Lynch, | Graduated Lynch High School in '68 | Resides in Lexington,

The dual influence that the local institution and early black successes had on the black community's posture towards pursuing a college education cannot be underscored enough. Porter G. Peeples was in $9^{\text {th }}$ grade at the time when Jerome Ratchford and his fellow classmates went up to Southeast Community College. He remembers looking up to the older guys in his neighborhood and attributes his own decision to attend college, as 
he would be the first in his family, to watching Jerome and other role models in his

neighborhood:

...some of the guys who I knew who went there before me, one of the main ones who went there was Jerome Ratchford, now Dr. Jerome Ratchford, and he is in Georgia running a college. Another guy from my street who didn't go to Southeast but went to Kentucky State on a football scholarship was Willie French. You know I looked up to these guys...they were role models, very positive role models. And we started saying 'yes we can'. That's what they said to me 'yes we can'. And you know I guess watching some of that was what made me get myself back on track, you know back to tenth or eleventh grade and say 'ooh wait I want to do what they're doing'.

Porter followed in Jerome's footsteps, attending Southeast Community College to attain his Associates degree and then transferring to the University of Kentucky to attain his Bachelors. After graduating from college, Porter decided to take root in Lexington and to devote his life to serving his community and his state of Kentucky. He is the President/CEO of the Urban League of Fayette County in Lexington, a position he has held since 1968, and serves on the Board of Trustees for all the community collegesincluding Southeast —in the Commonwealth of Kentucky.

\section{Dispersion}

They moved everywhere. Newington, Connecticut, Cleveland, Ohio, San Jose and Los Angeles, California, Indianapolis, Indiana, Chicago, Illinois, and Long Island, New York. There are few cities in America where you cannot find a black coal miners' child from Bloody Harlan County. It was a perfect storm of micro and macro level processes and assemblages that caused this particular out-migration to articulate itself in this way.

Figure X. represents where they currently reside today. 


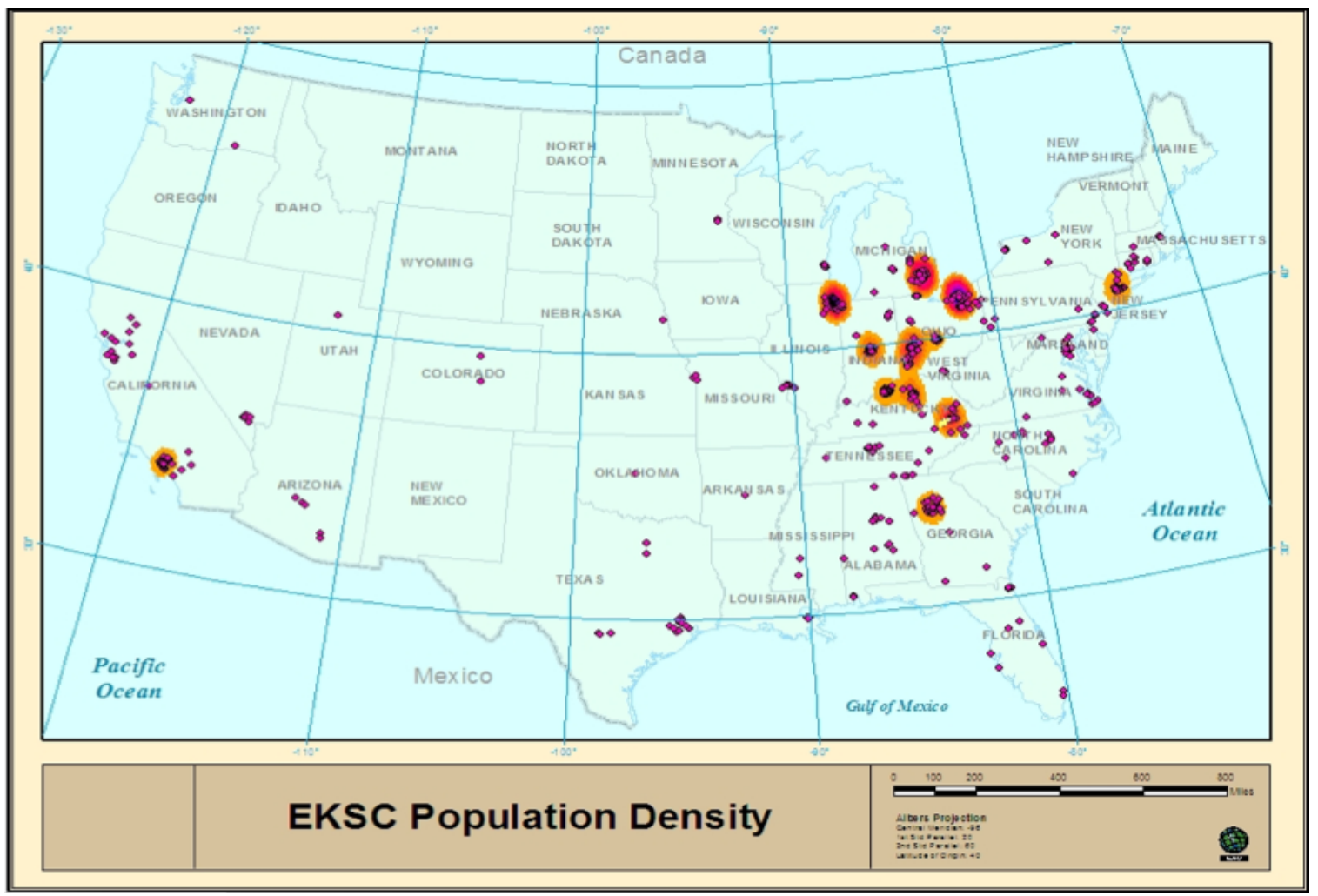

Figure 31. GIS map representing 1,300 Southeastern Kentucky African American families from the Eastern Kentucky Social Club 2004 mailing list.

Mapping on almost perfectly to the major destination cities of the African American Great Migration — with the most concentrated destinations being once booming industrial cities in the Midwest and North, later pathways in the West, which largely became a possibility because of the opportunities created by the pseudo-integrated Marines and the Air force, and finally a wave of return to South migrants who resettled there after retiring from careers in the North. However, theirs was not just a massmigration, it was a diaspora; characterized by collective feeling of loss, mourning, and homesickness that accompanies the experience of abrupt displacement and dispersion. In this way, diaspora is a consciousness. 


\section{Gone Home}

Today, the once bustling mining towns of Benham, Cumberland and Lynch resemble old Western ghost towns. International Harvester and U.S. Steel began mass layoffs shortly after the end of World War II as they stealthily prepared to close up shop and leave town. As the population dwindled, the companies maneuvered to relinquish their responsibility for the model communities that they created. The company homethe quintessential feature of any company owned town — would soon be no more. Blocks at a time, mothers and fathers, or sometimes children would return home to a pink notice on their door: the family that they would have ninety days to find another home, the company would soon be vacating their entire street. Some families resigned themselves to the obvious and chose to leave town at that point, while others were able to find available housing on other streets or camps.

In 1963, in a last ditch effort to divest in their housing inventory, United States Steel put out a notice that they were offering all of their employees the opportunity to partake in the American Dream, that they would be able to buy a house in Lynch. This no

doubt came as a sudden surprise given that the word ownership had never been associated with anything in those parts since the company town was established. However, many families jumped at the opportunity and did whatever they could to scrape up enough money to claim a stake in the bounty that King Coal had promised. These folks did not see the writing on the wall.

...I remember my dad and mom when we moved into that house, they purchased that house through acquiring money from relatives. My mom's sisters and brothers, family members, I don't know the exact ones but I remember my parents calling on them to help send maybe $\$ 100$ toward the $\$ 1,000$ it was going 
to cost to purchase that home. And they received that and they were able to buy that house at 422 First Street. It was a real sharp memory because I remember that amount of money was very tough for them to acquire, but you know family came to the rescue.

--Arnita Davis Brown | Born 1953 in Lynch, | Resides in Atlanta, GA

The houses sold for random amounts, from $\$ 500, \$ 800, \$ 1,000$, and $\$ 1,500$, really

whatever the company could shake down from one family to the next. However, by this time the ruination was already in motion. Entire camps were evacuated and eventually erased as though they never existed. Eighth and youngest child of Cleo and Sylvester Baskin, Dwayne, slowly became aware of what was happening to his community.

Unfortunately when I grew up there were only a couple of camps actually. It was just Number One, New Two, and then Number Five. So obviously the other coal camps had ceased to exist, but I just recall hearing the countless stories of Number Three, Number Four, the bath house and those types of things; to the point where I could sometimes visualize them because the physical structures were still there in a lot of cases...It was not until probably I became a young man or adolescent when I started recognizing that the class sizes were getting smaller and actually the school system itself became less and less and less. But I never thought that it wouldn't be there. That goes to the point of how much it was instilled in us that home is always going to be there and I never ever gave it any thought that it would dissolve to what it is now, to the point where literally very few people in Lynch as we speak.

--Dwayne Baskin | Born 1962 in Lynch, | Graduated Lynch High School '80 | Resides in Indianapolis, IN

Families had little choice in the matter. More and more fathers found themselves laid off or underemployed with a wife and eight or ten kids to feed. In these cases they had to move to survive, and with such large families, they could not always stay together. Brenda Thornton was only eleven years old when her bucolic life changed forever. 
Well, I remember that I was eleven years old and I was in the $6^{\text {th }}$ grade and I remember saying to God - we had to do plays, we did plays from every grade, grades 1-12 did a play. And the play that we were doing at this time was in the $6^{\text {th }}$ grade, I was in the $6^{\text {th }}$ grade and Ms. Jones was the teacher. And I remember that I had to practice with Anne Marie, Coleman and Lois Mitchell, we were going to be singing a song together. And because I was so afraid that I could not hold the tune I was saying to God, "can you get me out of this"?

And I guess my prayers were answered, I went home and my father said, we're going to have to take you kids to West Virginia to stay with your grandmother because I'm no longer going to have a job in the coalmine. I said, "God, I didn't ask for you to move me, I just asked for you to get me out of the play!" This was just before Christmas of 1960. We didn't know when but it would be soon. So I was not even too sure if I was going to have a Christmas in Kentucky...there was no warning as far as exactly when. I didn't even really have time to say goodbye. I never said goodbye to my classmates.

Brenda and her siblings did get to spend that one last Christmas in Lynch, and she even got to perform in the play. However, by the next month her parents packed her and her siblings in a car and sent them to live with their grandmother in West Virginia until her father could find stable employment elsewhere. They left over the winter break so she did not have the chance to announce her pending departure to her classmates. Instead, they just disappeared. Reflecting on how she felt during that car ride in '61 Brenda says: "I think I was in denial. I thought it was temporary and we would be staying with grandma, maybe just a short time and then we would come back home. I never thought it was permanent, I always thought it was temporary."

But it was not temporary. That was the last time Brenda would live in Kentucky. These were the moments when parents and children alike became aware of how disposable they were to United States Steel: just as the company giveth, the company taketh away: 
I think I realized it the day we left in 1961. I realized that whatever we had was controlled by U.S. Steel and that my life would change because U.S. Steel no longer had a position for my father. And that's when I realized that they controlled everything, that they controlled my destiny at that time. And it was very heartbreaking to realize that I wouldn't grow up with my friends and possibly never see them again.

--Brenda Thornton | Born 1950 in Lynch, | Resides in White Plains, NY

Brenda's experience with root shock was not unique. There are several stories of children unexpectedly "going for a ride" and not coming back.

...well, my granddaddy and grandmother said we were moving - we had no choice; we had no say in it. I'll never forget it. It was May 24th, 1959, we were walking home from school-Kenneth, Eddy, Brenda, and Cynthia - we all walked home from school; my grandmother had a car parked in front of the house and said "Get in." We had to go. We left that school; we didn't get a chance to say goodbye to our friends because we didn't even know we were leaving.

--Curtis Mason | Brown 195X in Lynch, | Resides in Chicago, IL

The Devolution of a Community 
The "colored schools"

in Benham and Lynch closed

their doors in 1963; in part

because of pressure by the

governor and in a larger part

because of the precipitating

population. The black children

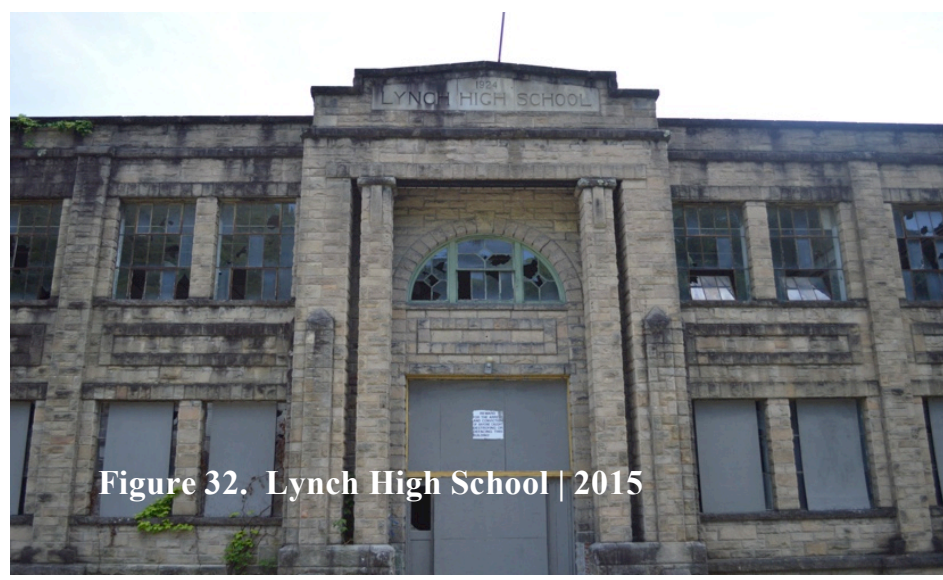

in Lynch integrated into Lynch High School, while all children in Benham were bussed to attend Cumberland High School, as the Benham School system closed in its entirety. As time when on, by 1981, Lynch High School closed its doors too. Over a series of school closures and consolidations over the years, there is presently only one public high school in Harlan County, Harlan High School, which is mandated to serve all children throughout the hills and hollows of those mountains. Children who reside in Benham, Cumberland, and Lynch travel twenty-one miles each way to attend school, while the remnants of the old schools in their communities stand tall, in ruin.

Both IHC and U.S. Steel began razing entire sections of town, especially in the black neighborhoods. Eventually, the homes from which families were evicted-empty artifacts of life and love — were bulldozed and left for nature to reclaim. Over time, the people who built their memories in those spaces began to wonder if they ever existed. 


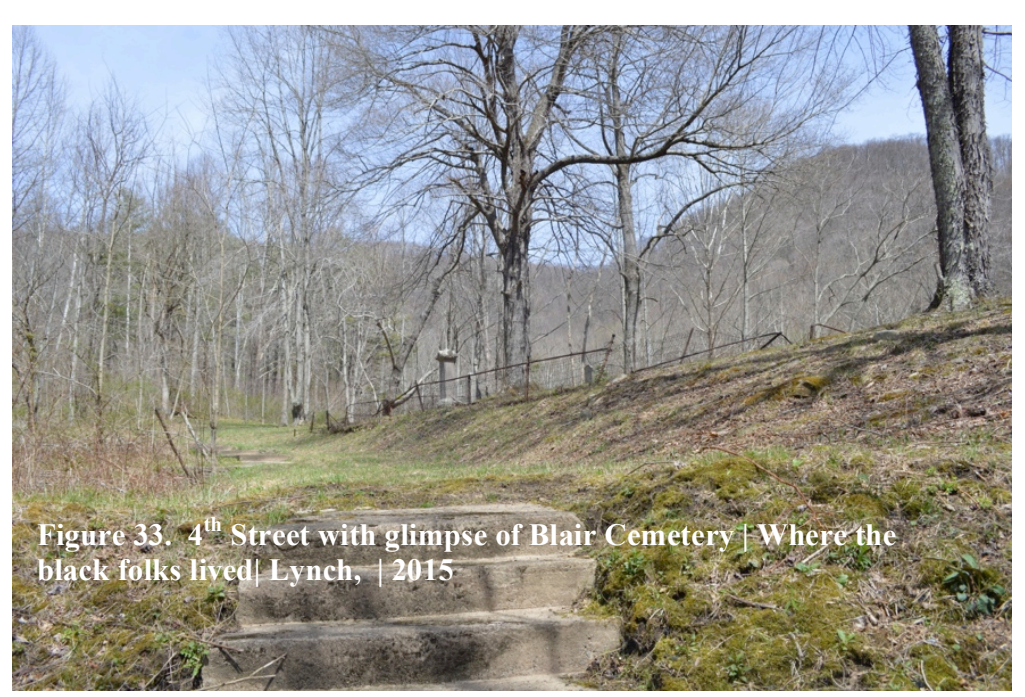

...no longer there, there's nothing there anymore. In fact when you go you can barely see the roads, when you're walking because it's so over grown now with weeds and trees and sometimes when we go home we try to find the graveyard. Because at the end of our very street, on $4^{\text {th }}$ Street, there was a grave yard there and so it's like we could not find the grave yard it's still over grown with weeds and stuff, yeah but -I can look at the mountains and still see pictures of that mountain that I saw as a little girl you know even though the houses are gone or just I don't know, it's strange but that will always be my home place.

--Sally Pettygrue Davis | Born 1941 in Lynch, | Resides in Covington,

...so we drove down to Cumberland, to Sawmill Hollow, and we drove to where my Uncle's was house supposed to be....and there's nothing there...at some point my uncle had tore the down the porch and filled it in with rocks and dirt and made a concrete porch, okay. So you got this long porch that's concrete and you got a block wall in the front that comes up about two feet and then poles to hold the roof. That was all that was left. And the rest has been bulldozed up into a pile of rubble... We had taken pictures until we got out of the car not realizing it...When we got there the whole trip psychologically ended. We never took another picture...you don't want that memory you know. You want the memory of the little house where you grew up as a kid that is not there anymore so we're not taking pictures.

--John Steward | Born in Cincinnati, OH in 1942; Reared in Benham, | Resides in Alisa Viejo, CA 


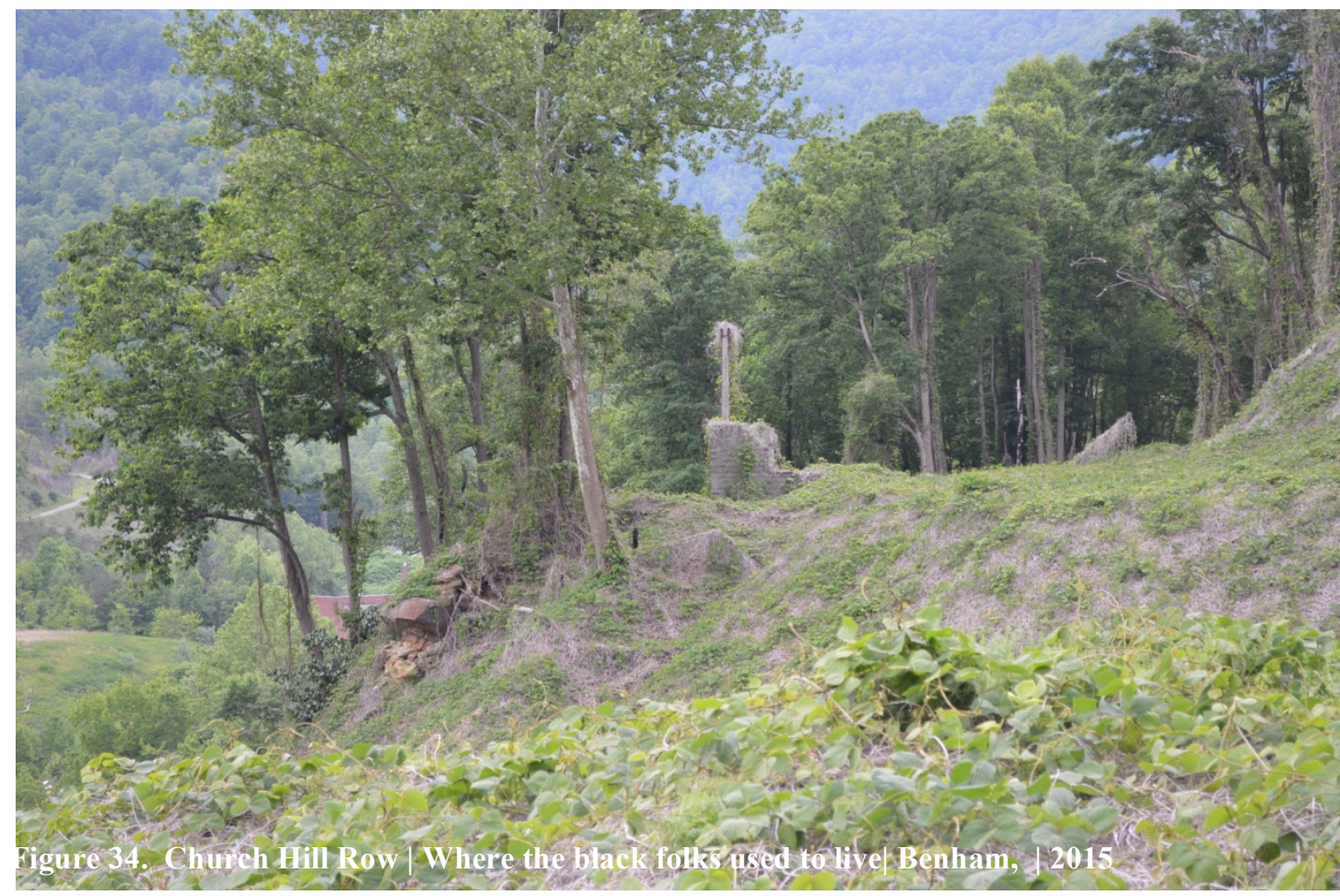

When Brenda Thornton returned to Lynch decades after being sent off to live with her grandmother in 1961, she was heartbroken to see that the home that she knew and loved was gone.

... and when I saw that it hurt. It was like I never lived there. There were no houses there, there was no community up there, it was just a mountain, and I could not believe that, not was not even a street going up there. And what hurts me more is that I have not been able to fill that gap in my mind, I don't know when they tore it down and I have no idea if anybody every took a picture of it before it was torn down.

--Brenda Thornton | Born 1950 in Lynch, | Resides in White Plains, NY

Most devastatingly, the people were gone-the "misters" and "misses" that they had to say hello to every time they saw them on the street, the children playing homemade 
games outdoors, picking wild apples and blackberries for their mothers to can, and catching lightening bugs, the black teachers who whooped their behinds, expected the best, and loved them like their own; they were all long gone. The four room homes that they grew up in watching their mothers cooking in the kitchen and their fathers chewing tobacco and staring at the daily paper, the homes where six or eight siblings shared two or three beds without wishing it was any other way. Eventually they witnessed a generation of fathers - their own fathers who did not talk — give their bodies back to the Black Mountain to which they sold them.

These men well understood thirty or forty years prior that that same coal mine that bought them their freedom would also issue them their death sentence. Going into the mouth of a mountain so dark and damp, digging a labyrinth of roc mineral under the earth, picking, exploding, and roof bolting; breathing in that coal dust eight to ten hours a day, five days a week, year in and year out over three to four decades—black lung was inevitable. It is one thing to witness the death of a parent-your mother, your father, or the person who raised you — it is quite another to witness everyone's' father die the same slow death, from the same disease, within a month or a year or two of your own.

These are the ties that bind. It is through this shared experience with community and culture, oppression and striving, pride and joy, landscape and environment, the sudden unraveling of the very social fabric that defined who they were, and the ongoing ruination of the built environment that their diasporic consciousness emerged. As I mentioned earlier, diaspora is not constitution solely through mass migration and dispersion, it is a consciousness, a practice, a stance-diaspora is a condition of subjectivity. Home did not pass away with distance or time for this generation of African 
American migrants, instead it transcended from a physical entity to a symbolic one. Over time, home became to symbolize death and memorial instead of life and expression.

So Christmas was an identifier, it was a symbol of the progress for black people from that community... and you saw fewer people coming home for Christmas, you knew that they were the roots, that having kin in that community was no longer present. In other words you had nobody that you could come and stay with or visit. So as families had to move out and you didn't have root familiesnuclear families - to welcome their offspring and so forth; you could see a decline in the people coming back for the major holiday for Christmas.

And then you actually saw literally a juxtaposition later on when more people were coming back to visit the deceased than they were to affiliate with their living relatives. So we went from Christmas being indicative of progress and prosperity and so forth to Memorial Day...So I absolutely remember coming home and wondering why more people were not at home. And you sort of over a period of time, you gradually saw that that phenomenon was going out of existence.

Through decades of going and returning, remembering and storytelling, performing and presenting, they have rescued home from erasure. Although African Americans are largely overlooked in the national narrative of Appalachia, these black people have reinscribed their being into this place. Through these practices they remind themselves that "we were here." Perhaps this is what Charles Horton Cooley (1992) meant by his term "self-feeling".

So we still go home and when I go home it gives me an opportunity to fill my tank up. Sometimes in the city your tank gets so empty and you have to refuel. So when I go back home to rejuvenate the mountain spirit, it's all through the concept of home. Because at home you don't have to impress nobody, you can just be yourself, it is home. Also we're seeing home before our eyes, we're seeing the mountains die, we're seeing the streets being swallowed up with the trees, we're seeing death which is imminent to all of us. Where I'm the youngest of eight in my family, we've now lost two siblings. 
I must say that when I go home there's nobody living in our home any longer but we still keep a homestead, we still have electricity on in our home, we still got the water on in the home but nobody lives in the home any longer. But home is where mama and daddy raised us in that little house. So I sort of call it our condo in the mountains. Another thing is, the mountain has a way of defining who you are, your character, you have something that's symbolic that you have to hang on to.

--Jeff Turner | Born 1959 in Lynch, | Resides in Indianapolis, IN

\section{Memorial Day Weekend}

Every Memorial Day Weekend, the black folks who grew up in the Tri-Cities area of Harlan County, return home. They come in from all over the country, from Springfield, Massachusetts, to Los Angeles, California, and everywhere in-between. During this long holiday weekend, the communities resurrect as though nothing has changed. The few families that still own their family homes return to the homestead, with two, sometimes three generations piled into one little house. Homefolks go from house to house visiting each other, participating in community festivities, eating each other's barbeque, and socializing at "the club"- otherwise known as the Lynch Colored Public School.

Memorial Day, from all my life I can remember, that was the week that everybody that ever lived in Lynch came back home. And I can remember it was just like a reunion, we went to the cemetery to put flowers on the graves. You just see so many people, and it was just the way we did things, you know. Back then there were a lot of people in Lynch, you know when I told you I lived in Number Three, now it seems Number Three doesn't even exist.

-Brenda Clark Combs | Born, 1954 | Resides in Lexington,

...I do not know how it started, but I know it started longtime ago before I even started coming back. Now, to show you the importance to me, I would come all the way from here just for the weekend;...I would come back that weekend just to be with my friends, that I grew up and have known all of my life. You know where First Street is? You'd have twenty-five cars lined up, and nobody would 
be blowing their horn for you to move, can you believe that?...So, I can remember coming home and starting at my mama's house and working my way all the way down the street, and then up Second Street, speaking to everybody on those two streets, First and Second Street... [It would take you] the whole day! You had to speak to everybody. A lot of them want you to come in and have a drink or come in and get something to eat. Maybe you would get a piece of chicken on your way out...Everybody would be outside their car, standing up; and you would walk from your car all the way down to that car; that is how it was on Memorial Day. I do not know how the tradition started but I love it. I love it.

--William Jackson | Born 1944 in Lynch, | Resides in Los Angeles,

The dénouement of the weekend is the church service at Greater Mt. Sinai Baptist Church on Sunday morning, followed by a trip to the cemetery to dress the tombstones of family, friends and loved ones. By Monday morning, everyone is gone.

The meanings laden in the ritual of "coming home" for Memorial Day are laden with dualities, as it is both sacred and profane, it is about life as much as it is death, as well as it is about presence and absence.

Yeah, Memorial Day is a sacred day. It is a memory of the ones gone and it became the tradition of our community of Lynch to just seek some refuge in that quietness of being home in that little town leading up to the church service on Sunday for the memorial of whomever's parents or loved ones had deceased and visiting the grave side down there. The whole weekend is centered around that memory and as our parent's became the deceased ones we became even more driven to just go back and pay that respect to the ones that are gone like when we go to church would just spiritually uplift you. You know they don't live here anymore, you know they could not sing a song that didn't touch you, and it makes you think about your parents. [Speaking of her in-laws and her own parents] I remember when Mr. Major first passed, when Miss Leona passed, when my parents passed. So it just always brought us together just to you know share a little communion away from the busyness of you know city life and the stresses that you endured. I don't know. It's just something sacred I would say about Memorial Day and that weekend.

-Arnita Brown | Born 1953 in Lynch, | Resides in Atlanta, GA 
The meaning of the tradition oscillates between extended community-level experiences with loss, to direct personal experiences, as the loss of one parent or family member resonates deeply as a blow to the entire community. It is a place of mutual recognition, where everyone understands the history, context, and meaning of the simultaneous sense of peace and sorrow that home conjures in their spirits. The weekend is not only a time to remember those who have passed on, it is also a time to reconnect and rejoice with the living.

...that's what happened in Lynch during Memorial Day, everybody would drive home, nice, fine cars and their kids and spouses and what have you and it was common for $1^{\text {st }}$ Street to be blocked - full of traffic. And you just understood that if you could come home for Memorial Day that there's just going to be a traffic jam up and down that street and you're just going on and park your car, you're not going to be able to move forward. And you reconnected, exchanged pleasantries, hugged, kissed and just reacquainted yourself out of joy in a lot of cases... it was that spirit of just coming back together, fellowship and just enjoy seeing each other, everything else just stopped. And it's hard to describe it, and I get a little choked up right now just thinking about it - a lot of my classmates are no longer with me. And to remember a lot of the folks that would come back for this Memorial Day Festivity and it still continues on a lesser scale because - I don't have any blood relatives still in Lynch but this is still home, that's my place of birth and that's where my father is buried and my mother is buried in San Jose.

-Jeffrey Ratchford | Born 1956 in Lynch, |Resides in Atlanta, GA

Returning to Kentucky for Memorial Day is one way in which they claim their roots by situating their memories in place. It is an "invented tradition" that restores some sense of materiality to their collective memory and serves as a referent to for the narrative they construct as to "who we are." However, their performance of home extends well beyond the physical borders Harlan, County. They have also adopted traditions that honor the physicality of home, but that also perform the homelessness of it all—an expression of their roots and routes. 


\section{The Eastern Kentucky Social Club}

In 1969, seven Benham migrants living in Cleveland, Ohio decided to host a reunion to reconnect with other friends and community members who had also partaken in this intergenerational journey through the hills of Kentucky. One year later, after much discussion and planning, they hosted their first reunion at a bar on the east side of the city. The organizers spread invitations by word of mouth through family and community networks. Without a clear estimation of the turnout, the organizers found themselves hosting a reunion that drew over three hundred home folks coming in from cities all across the country.

This inaugural event sparked the establishment of the Eastern Kentucky Social Club (EKSC). Chapters of the organization sprang up in over fifteen cities across the country, each passing the other the baton of responsibility for hosting the following year's reunion. The club expanded to include members from other nearby coal mining communities in the eastern Kentucky, and at its height the EKSC drew over three thousand African American migrants to the event. These reunions have continued without interruption each year for nearly forty-five consecutive years, existing for the sole purpose of creating a space for African Americans who share roots in the coal towns of eastern Kentucky to reunite.

...through that thing of the Kentucky social club we keep networking you know we keep that connection. And you know I try to explain to people as well everybody came out of the little town and all of the United States and they formed the Eastern Kentucky Social Club in their particular city. And it goes from one city to another; you got the Kentucky Social Club in New York, Chicago, Cleveland, Atlanta you know. Each one gets the time and host more and all the other social clubs come to that one.

--Albert Harris |Born, 1950 in Benham, Kentucky | Resides in Sunrise, FL 
Both Memorial Day and the EKSC Reunion are sustained through the collective memories of these migrants and are full of rituals and practices that perform "home". These traditions are the connective tissue that bind their pasts' with the present, and allows home to exist in the realm of the symbolic. Brenda Thornton knows this all too well. During a serendipitous encounter in Detroit, Michigan, she bumped into a fellow eastern Kentuckian who told her about the EKSC reunions. She was an adult now, it had been over twenty years since that day she left Lynch in the middle of her $6^{\text {th }}$ grade year. She attended that year's reunion and almost every one since. She explained why she attends:

Because that was the most important part of my life. That was my home, that was where I was born at. I never wanted to leave Lynch Kentucky, I always wanted to go back and the only way I could go back was through the Eastern Kentucky Reunions. I went back twice after I left when I was 11 years old and each time I went back it was like a tease. Lynch Kentucky was like no other part in the whole United States, there were people there that you could count on, you were in the class with these kids from the time you were years old, you formed bonds with them, they knew you more than anybody.

Now that the population is in their $70 \mathrm{~s}, 80 \mathrm{~s}$, and $90 \mathrm{~s}$, attendance has been greatly impacted by illness, disability and mortality. However, the reunions are still active and draw migrants by the busload to partake in the tradition. This year's (2016) will be in Memphis, Tennessee.

\section{Race and Roots through Appalachia}

Yeah, but home, Lynch will always be home to me. Always. People that are from the city think that we are from the Appalachian Mountains and we are just a bunch of hillbillies. But we're not hillbillies honey! And I am proud to be from that mountain. I am proud of my learning, my teaching, my training and 
everything that I learned from up there...And we had it good, we had beautiful homes and everything... and U.S. Steel saw to that. And we had beautiful churches and what have you. And I tell you that there was so much love there and I will never forget it. Lynch is home for the kids that were raised there. And you could not find a better place. And one day I went to the city and one of the ladies asked me where you from and I said from the Appalachian Mountain, Lynch, Kentucky and she told me that I was telling her lie.

--Lena Margaret Jones | Born 1938 in Lynch, | Resides in Louisville,

$* * *$

In my heart, Lynch is home, and it never will be nowhere but there. (Chuck Rodgers | Lexington, ) Home will always be 469 First Street (Dwayne Baskin | Indianapolis, IN) And I tell anybody we are from Kentucky; we're from Lynch - "where is it at?" "Well, do you know Harlan County?" and I try to explain it to them, then I go to naming people that came out of those hills and they say, "you're kidding!" I say, "No, they came out of those hills." (Curtis Mason | Chicago, IL) Harlan County; Benham, Kentucky! (Odell Moss $\mid$ Lexington, ) Lynch will always be my home. I don't care where I go; Kentucky is my home. I mean, you can't take that away; that is where I got my beginning, and that is I learned to love people. (Barbara Haury $\mid$ Chicago, IL) Lynch. Lynch is home. I live in Lexington, but Lynch is home, yes. (Brenda Clark Combs) Home is always in Kentucky, Lynch. You know even now when somebody asks me where I'm from, when I'm away, I will say well I live in Waterbury, Connecticut but originally I'm from Lynch, Kentucky. (Humes Perry | Waterbury, CT) I still have a very, very sensitive, compassionate feeling for home. I love Lynch, I love home. I love the people. (Joyce Hall) Benham. This is my roots. This is my roots. This is home here. There is no place like it. There is no group of black people that are growing up in United States that equally. (Albert Harris $\mid$ Sunrise, $F L)$ Lynch - I live in Lexington that's what I tell people when I am travelling and they ask "where are you from?"..."Well, I live in Lexington but I am from Lynch, Kentucky. And Lynch is a small town in Harlan County and you know in Southeast, Kentucky." You got to explain all that to them but that's and home - Lynch is home. (Lee Arthur Jackson | Lexington, ) Lynch will always be my home. (Porter G. Peeples | Lexington, ) Lynch! Oh Lynch will always be my home. I have been here forty-four years, but Lynch is my home. I just moved out to California, but when you say home-I am a Kentuckian. Born and bred right there in Lynch, Kentucky. (William Jackson | Los Angeles, CA) You know what Lynch is still home for me. In spite of all the boarded houses and torn down houses, there is no place like home. When I go there you would think that place was still filled with people. It's the feeling that when you hit that street and you are in Lynch - that is my home, that is my home. (Sally Pettygrue Davis | Covington, ) 
Why? Because I was born and raised there, all my family was born and raised there. And before my people passed away their home was there. And when people began to pass away that's where they are buried, right at Benham, now I have an older brother who was not buried there but the rest of them they were buried right there in Benham. And my baby sister, she was buried there because she was cremated but we buried, at least I did buried her right down between mom and daddy, you see. And you know, because my oldest brother was the only one who was not buried there. I've already prepared things for myself to be buried there, everything is this already set and lined up and everything.

-Odell Moss | Born 1932 in Benham, | Resides in Lexington,

Well, it's important to me because we all started on the same playing field more or less. And I like it because I think we really have a rich heritage because sometimes I just sit down and think and remember all of the people that I know, the families that I know that had lots of kids or didn't have lots of kids. Like almost everybody from up in our hollow that I know. The ones that stayed down there, that lived down there graduated high school. I came to Milwaukee when I was fifteen and I didn't graduate high school. But all of the children that I went to grade school with down there all graduated high school and went on to college. I like that. And I have my being down there - I wish that I could have stayed down there up until high school. But I love all of them people. And I go just to keep a little piece of that alive - every year. I've missed a couple of years but I try to go so I can have a little memory. And I love it.

-Roselyn Baker | Born 1944 in Jenkins, | Resides in Milwaukee, WI

Because of the way I was raised, the culture, the love that I still feel for the people that I grew up with and the love I have for Lynch, that is why I say it is home, because it is just in me. Everything that I believe in or obtained. Caring for people when you were having that respect that came from Lynch, because of the way I was raised and that never left me and that is just home for me.

--Richard Brown | Born 1947 in Lynch, | Resides in Atlanta, GA

Well, if I could do that, I could probably explain to you why the Salmon goes back and does its thing- it's just a part of you. I mean, this is home. I love it; it's home.

--Leslie Lee | Born 194X in Lynch, | Resides in Harlan, 
I think because it's close-knit, it's a small town, I think it's mainly to do with our school, our teachers, our church, our neighborhood. We didn't have much. That was our world. Imagine yourself - it was a valley, a community surrounded by mountains and we were just all in that little community. So that's all we knew, so we became close, families became close. So I basically think that's why we're connected. And I hope that's why we're connected because of our upbringing.

--Cynthia Brown Harrington | Born 1954 in Lynch, | Resides in Greensboro, NC

\section{Conclusion}

Over the course of the last six decades, this black diaspora has invented a repertoire of practices, rituals, and traditions to archive home- the place from whence they came, if only for one generation, through the long duree of black migration in America. The "changing same" of dispossession and dislocation is inherent to mass movement of the black body in this country in all of its variety of iterations; from the forced migration that was the trans-Atlantic slave trade to the great escape of the first wave of the Great Migration, to the subsequent outpour of black lives from the South to the rest of the nation that ultimately shaped the composition and character of the American city. In this way, like all African American people home is always already and elusive concept. The natal alienation from a physical "place" of origin - for we are no more African than we are American, but all the time African and American — stirs in our souls a will of autopoesis--an internal, eternal drive for self-making. It is the improvisation of blackness. 


\section{CONCLUSION}

For th[e Sociological] imagination is the capacity to shift from one perspective to another-from the political to the psychological; from examination of a single family to comparative assessment of the national budgets of the world; from the theological school

to the military establishment; from considerations of an oil industry to the military

establishment; from considerations of an oil industry to the studies of contemporary poetry. It is the capacity to range from the most impersonal and remote transformations to the most intimate features of the human self-and to see the relations between the two.

C. Wright Mills ([1959] 2000, p. 6) | The Sociological Imagination

[Sociological interpretation] should aim to study those finer manifestations of social life which history can but mention and which statistics can not count, such as the expression

of Negro life as found in their hundred newspapers, their considerable literature, their music and folklore and their germ of esthetic life--in fine in all the movements and customs among them that manifest the existence of a distinct social mind."

W.E.B. Du Bois (1898) | The Study of Negro Problems

\section{A Reflexive Note}

In this dissertation I aimed to contribute to our understanding of African

Americanness. My personal challenge was to take the training that I had received at Brown - from courses in demographic techniques, geographic information systems (GIS), qualitative methods, to courses in history and critical theory - and stretch my sociological imagination to its outermost limits in order to conduct an analysis that spanned, as $\mathrm{C}$. Wright Mills says, "from the most impersonal and remote transformations to the most intimate features of the human self_-and to see the relations between the two." What, through this era of social change and transformation, disruption and dislocation, striving, progress, and disappointment, was the character and quality of the black social mind? 
For me, the challenge to put together a research design for this type of study was a tremendous undertaking. My primary matter of concern was African American subjectivity, which necessitated that I had access to data that would allow me to interpret not only what black folks were doing; but also who they were and who they understood themselves to be. I chose the African American Great Migration as the macro-level event with which to undergird this study because it captured the geographic, temporal, and spiritual elements of the Twentieth Century black experience that I was interested in examining. However the entire mass-migration from the Deep South to the North was too great and varied an experience to analyze for the goal of making claims about African American subjectivity. There was great variety in the paths that African Americans took throughout the Great Migration; their struggles varied, and they accumulated different worldviews, dispositions, experiences, and aspirations along the way. To avoid the risk of essentializing such a diverse population, I chose to limit my analysis in this dissertation to a single case.

Collecting the data for this project was like performing an archaeological dig, excavating the archive of an ancient lost city. As I discussed in Chapter Two, there was very little to be found about the black experience in Appalachia in the formal institutional archives, necessitating that I access data from nontraditional sources. My quest for sources lead me to undertake a community study, which is the sociological tradition that W.E.B. Du Bois employed in his early research projects over a century ago. Studies such as The Philadelphia Negro and his series of Atlanta University Studies that he carried out from the late $19^{\text {th }}$ century through the mid-1920s are prime examples of the methodology he developed for the social analysis of the black community. 
From a methodological standpoint, Du Bois was adamant that any study of the black community required the interpretation of a combination of historical, statistical, and cultural data; as well as an unflinching acknowledgement of the social force race prejudice (Du Bois, 1898). Echoing the epigraph above, the traces of black life are found in cultural expression, our gestures, jokes, sorrows, and moans; leaning on Diana Taylor's (2003) phraseology, the stuff of blackness lies just as much in the repertoire as it does in the archive.

Through my experience with conducting interviews for this project, I discovered what a powerful methodological tool oral history presented to Sociology. My research participants shared their stories, stated their political philosophies on all manner of issues, and decided how they wanted their historical documents managed, and contributed to the research by donating source materials to the EKAAMP archive. I offered them the option to have their interview materials anonymized, fictionalized, or named and made public for future research through the archive at the Southern Historical Collection at the University of North Carolina at Chapel Hill, and all but one opted for the latter. Beyond their individual interviews, dozens of participants have stayed in close contact with me to follow up with me on my progress on "their" book! From beginning to end, this has truly been a collaborative research project.

\section{Striving, Transformation, and the Improvisation of Blackness}

Our America has transformed many times over from its founding in 1776 to this present moment. Our quest to live up to the ideals upon which this country was founded, to incorporate them into our daily lives and practices, and to outwardly project those 
ideals as a collective demonstration of who "we" are, has been ongoing. Of all of the eras and moments of change, the Twentieth Century marked a period of rapid, contentious, and structural transformation in America's racial landscape. This was not only a period where transformational events occurred, it was a period were they were televised. Unlike the century before, black struggle for Life, Liberty, and Happiness was on stage for the world to bear witness, and whether or not they participated in picket and protest, the black folks represented in this study were all active participants in reshaping the American landscape. Yet and still, through all of the progress and transformation, the American racial states' latent disposition would flare and remind them of the changing same.

My analysis in this dissertation is both structural and phenomenological; and it is just as much about American society as it is about African American subjectivity. Even while living under the oppressive conditions of post-Reconstruction Alabama our country's unintended still managed to dream of an America that included them-one where their thread too could be woven into the social fabric of the "we the people". On those journeys, those men and women risked their lives in their attempt to escape, and we can be sure not all of them made it safely to their final destination. Those who did make it forfeited their own homes - everyday interactions with their families and communities, country landscapes, familiar faces, smells, that red dirt of the South, and their memories - to advance their striving towards what they believed could be their promised land. A clean slate: this is the inheritance that they hoped leave to their kids.

Born in the margins of the margins - black in Appalachia — the progeny of the first generation migrants grew up on what looked a very different racial landscape than 
they had endured just one generation before. Under the blanket of the company town, there was no racial contract that allowed for the local white men to "come see about" a black man's wife, no convict labor or chain gang, no sharecropping agreements, and no lynching. Their generation, these coalminers' children were a symbol of racial progress. They lived through the Civil Rights Movement and helped lay Jim Crow to rest, they were on the front lines of desegregating our country's public school system, they were a generation of "firsts"- they were the ones who, all in one generation, went from "Colored, to Negro, to African American, and Black". However, as my analysis revealed in Chapter Four, what seemed like a progressive racial landscape in the company owned towns was in fact a new genre of the same racial project of the Old South. What America called racial progress was a move towards a post-racial society, which really meant a society where individuals no longer had to bear the responsibility for maintaining the racial order (Bonilla-Silva, 2003). This was a transformation in the history of U.S. race relations, in that institutions, systems, and racial ideology did the work that hate groups, statesman, mobs, and individuals from the dominant group once did. Under this new system, American society began to prefer their racism under the veneer of politeness. At the same time, African American's civil rights and access to U.S. institutions were expanding broadly as a result of the Civil Rights Movement.

I attempted to trace the ways in which African Americans navigated this new landscape; one shaped by "racism without racists" (Bonilla-Silva, 2003) and a broadened horizon of possibilities. I used the oral history interviews to "grasp history and biography and the relations between the two", as this is the task and the promise of the sociological imagination (Mills, 2000, p. 6)". What I found was that African Americans continued 
striving in their quest towards full incorporation in American society in spite of their awareness of the unfair realities and challenges of racial subjugation. They knew that they were not competing on a level playing field in the public sphere, however they held on to the ideal of full citizen. In that way, one of the broad findings of this project is that the Twentieth Century African American project was largely one of incorporation.

However, incorporation is not the same as assimilation. All of the empirical chapters of this dissertation shows that there is and always been a rich and uniquely black culture that thrives within the African American community and pours out into mainstream society. This incorporative project is the impetus for the twoness that $\mathrm{Du}$ Bois (1903) articulated in Souls, the desire to be both Negro and American without one negating the other. Nowhere in the dissertation is this more apparent than in Chapter Seven, "Gone Home”, where I discuss the emergence of my participants' diasporic consciousness. Their shared experience with displacement, loss, and ruination conditioned a homeland attachment that is analogous to what is typically observed in transnational mass-migrations. Through their invented traditions, practices, and rituals, they articulate and refashion their collective identities, and they reinscribe themselves in the regional narrative of Appalachia in spite of their apparent erasure.

One immediate contribution that I hope this dissertation makes is to illuminate the inherent tensions and duality of the veil. The sociological literature on African American community and culture is dominated by the research focusing on the social ills of the black urban environment (Anderson, 2003; Goffman, 2009, 2015; Venkatesh, 2008). While studies like these shed light on aspects of the African American experience by illustrating structural effects racialization and hyper-segregation, as a body of literature 
these studies can easily translate into a culture of poverty argument that pathologizes blackness as abject and criminal [for exceptions see (Lacy, 2007; Pattillo, 2013; Young, 2006). However, also resultant of the veil is a remarkable resistance, culture, and artistic improvisation that is also characteristic of African American culture. Also important to highlight is that black life has always mattered to black people. This study is one example of the ways in which that self appreciation takes place in spite of and behind the veil.

\section{CODA}

After presenting the main findings of my research a colleague once asked me, “What's the counterfactual?" Admittedly vexed, I did not respond as thoughtfully as I should. In a moment of my own hubris, I found the question trite and did not do the work to offer a thoughtful response. However that is the one question that I have continued to chew on as I worked through writing this dissertation. It turns out that his was the question. My only regret with coming to this conclusion is that I was not thoughtful enough at the time to have had an earnest response prepared when I was first asked. However, I am most grateful to my colleague who pushed me to think outside of the bounds of what I assumed was obvious. Therefore, I close this dissertation with the counterfactual; the alternative explanation that would explain "if A had not occurred, C would not have occurred (Menzies, 2014).

\section{The Counterfactual}

We hold these truths to be self-evident, that all men are created equal, that they are endowed by their Creator with certain unalienable Rights, that among these are Life, Liberty and the pursuit of Happiness. That to secure these rights, Governments are instituted among Men, deriving their just powers from the consent of the governed, -That whenever any Form of Government becomes destructive of these ends, it is the Right of the People to alter or to abolish it, and to institute new Government, laying its 
foundation on such principles and organizing its powers in such form, as to them shall seem most likely to effect their Safety and Happiness.

--The Declaration of Independence (July $\left.4^{\text {th }}, 1776\right) \mid$ The unanimous Declaration of the thirteen United States of America 


\section{BIBLIOGRAPHY}

Alcoff, L. M. (1999). Towards a phenomenology of racial embodiment. Radical Philosophy, (95), 15-26.

Alcoff, L. M. (2005). Visible identities: Race, gender, and the self. Oxford University Press.

Alexander, J. C., Eyerman, R., Giesen, B., Smelser, N. J., \& Sztompka, P. (2004). Cultural trauma and collective identity. Univ of California Press.

Algeo, K. (2003). Locals on local color: Imagining identity in Appalachia. Southern Cultures, 9(4), 27-54.

Allen, D. (2009). Talking to strangers: Anxieties of citizenship since Brown v. Board of Education. University of Chicago Press.

Althusser, L. (1971). Ideology and ideological state apparatus (Notes towards an investigation). I Lenin and philosophy and other essays (ss. 127-186). New York: Monthly Review Press.

Anderson, E. (2003). A Place on the Corner. University of Chicago Press.

Anderson, J. D. (1988). The education of Blacks in the South, 1860-1935. Univ of North Carolina Press.

Bailey, K. R. (1973). A judicious mixture: Negroes and immigrants in the West Virginia mines, 1880-1917. West Virginia History, 34(2), 141-161.

Bartmanski, D., \& Eyerman, R. (2011). The worst was the silence: The unfinished drama of the Katyn Massacre. Narrating Trauma: On the Impact of Collective Suffering. London: Paradigm Publishers, 237-266. 
Bell, D. (2004). Silent covenants: Brown v. Board of Education and the unfulfilled hopes for racial reform. Oxford University Press.

Berezin, M. (2014). How Do We Know What We Mean? Epistemological Dilemmas in Cultural Sociology. Qualitative Sociology, 37(2), 141-151.

Berger, P. L., \& Luckmann, T. (1991). The social construction of reality: A treatise in the sociology of knowledge. Penguin UK.

Blackmon, D. A. (2009). Slavery by another name: The re-enslavement of black Americans from the Civil War to World War II. Anchor.

Bogues, A. (2010). Empire of Liberty: Power, Desire, and Freedom. UPNE.

Bogues, A. (2012). And What About the Human?: Freedom, Human Emancipation, and the Radical Imagination. Boundary 2, 39(3), 29-46.

Bonilla-Silva, E. (2003). Racism without racists: Color-blind racism and the persistence of racial inequality in the United States. Lanham, MD: Rowman \& Littlefield.

Bosniak, L. (2008). The citizen and the alien: dilemmas of contemporary membership. Princeton University Press.

Bottomore, T. B., \& Marshall, T. H. (1992). Citizenship and social class. Pluto Press. Bourdieu, P. (1990). The logic of practice. Stanford University Press.

Cabbell, E. J. (1980). Black invisibility and racism in Appalachia: An informal survey. Appalachian Journal, 8(1), 48-54.

Castles, S., \& Davidson, A. (2000). Citizenship and migration: Globalization and the politics of belonging. Psychology Press.

Caudill, H. M. (1962). Night Comes to the Cumberlands. Boston: Little, Brown and Co. 
Caudill, H. M. (1983). Theirs be the power: the moguls of eastern Kentucky. Univ of Illinois Pr.

Cecelski, D. S. (1994). Along freedom road: Hyde County, North Carolina and the fate of black schools in the South. Univ of North Carolina Press.

Césaire, A. (2000). Discourse on colonialism. NYU Press.

Ceuppens, B., \& Geschiere, P. (2005). Autochthony: local or global? New modes in the struggle over citizenship and belonging in Africa and Europe. Annu. Rev. Anthropol., 34, 385-407.

Cobb, J. S., \& Hoang, K. K. (2015). Protagonist-Driven Urban Ethnography. City \& Community, 14(4), 348-351.

Cooley, C. H. (1992). Human nature and the social order. Transaction Publishers. Crawford, M. (1995). Building the workingman's paradise: the design of American company towns. Verso.

Cressey, P. F. (1949). Social disorganization and reorganization in Harlan County, Kentucky. American Sociological Review, 14(3), 389-394.

Crowder, K. D., Tolnay, S. E., \& Adelman, R. M. (2001). Intermetropolitan migration and locational improvement for African American males, 1970-1990. Social Science Research, 30(3), 449-472.

Debs, M. (2013). Using cultural trauma: Gandhi's assassination, partition and secular nationalism in post-independence India. Nations and Nationalism, 19(4), 635-653.

Derrida, J. (1996). Archive fever: A Freudian impression. University of Chicago Press. Descartes, R. (1960). Discourse on method: and other writings. Penguin Books. 
Diehl, H. (2007). Dream not of other worlds: Teaching in a segregated elementary school, 1970. University of Iowa Press.

Dinius, O. J., \& Vergara, A. (2011). Company towns in the Americas: landscape, power, and working-class communities (Vol. 4). University of Georgia Press.

Douglass, F. (1852). What to the Slave is the Fourth of July? Rochester Ladies AntiSlavery Society, Rochester, New York, 5.

Du Bois, W. B. (1898). The study of the Negro problems. The Annals of the American Academy of Political and Social Science, 1-23.

Du Bois, W. B. (1935). Does the Negro need separate schools? Journal of Negro Education, 328-335.

Du Bois, W. E. B. (1899). The Philadelphia Negro: a social study. University of Pennsylvania Press.

Du Bois, W. E. B. (1901). The Negroes of Dougherty County, Georgia.’. On Sociology and the Black Community.

Du Bois, W. E. B. (1903). The souls of black folk. Chicago: A.C. McClurg \& Co.

Du Bois, W. E. B. (1940). Dusk of dawn: An essay toward an autobiography of a race concept: The Oxford WEB Du Bois (Vol. 8). Oxford University Press on Demand.

Du Bois, W. E. B. (2013). Black Reconstruction in America: Toward a History of the Part Which Black Folk Played in the Attempt to Reconstruct Democracy in America, 1860-1880. Transaction Publishers.

Duff, B. P. (2004). Class and gender roles in the company towns of Millinocket and East Millinocket, Maine, and Benham and Lynch, Kentucky, 1901-2004: A comparative History. Citeseer. 
Durkheim, E. (1915). The elementary forms of the religious life. New York.

Durkheim, E. (1956). Education and Sociology, trans. SD Fox, with an Introduction by Talcott Parsons (Glencoe: The Free Press, 1956), 123.

Durkheim, E. (2012). Moral education. Courier Corporation.

Erikson, K. (1995). Notes on trauma and community. Trauma: Explorations in Memory, $183-99$.

Erikson, K. T. (1976). Everything in its path. Simon and Schuster.

Eyerman, R. (2001). Cultural trauma: Slavery and the formation of African American identity. Cambridge University Press.

Eyerman, R. (2004). The Past in the Present Culture and the Transmission of Memory. Acta Sociologica, 47(2), 159-169.

Eyerman, R. (2011). The Cultural Sociology of Political Assassination: From MLK and RFK to Fortuyn and Van Gogh. Palgrave Macmillan.

Fairclough, A. (2004). The costs of Brown: Black teachers and school integration. The Journal of American History, 91(1), 43-55.

Fairclough, A. (2009). A class of their own: Black teachers in the segregated South. Harvard University Press.

Fanon, F. (1967). Black Skin, White Masks. 1952. New York.

Foucault, M. (1977). Discipline and punish: The birth of the prison. Vintage.

Foucault, M. (2002). The order of things: An archaeology of the human sciences. Psychology Press.

Foucault, M. (2012). The archaeology of knowledge. Vintage.

Frazier, E. F. (1974). The negro church in America. Schocken. 
Gates, H. L., \& Jarrett, G. A. (2007). The new Negro: readings on race, representation, and African American culture, 1892-1938. Princeton University Press.

Geschiere, P. (2009). The perils of belonging: Autochthony, citizenship, and exclusion in Africa and Europe. University of Chicago Press.

Giddens, A. (1984). The constitution of society: Outline of the theory of structuration. Univ of California Press.

Gilroy, P. (1993). The black Atlantic: Modernity and double consciousness. Harvard University Press.

Gitelman, H. M. (1988). Legacy of the Ludlow massacre: A chapter in American industrial relations. Philadelphia: University of Pennsylvania Press.

Glazer, N. (1993). Is assimilation dead? The Annals of the American Academy of Political and Social Science, 530(1), 122-136.

Glenn, E. N. (2011). Constructing citizenship exclusion, subordination, and resistance. American Sociological Review, 76(1), 1-24.

Goffman, A. (2009). On the run: Wanted men in a Philadelphia ghetto. American Sociological Review, 74(3), 339-357.

Goffman, A. (2015). On the run: Fugitive life in an American city. Picador.

Gordon, A. F. (2008). Ghostly matters: Haunting and the sociological imagination. U of Minnesota Press.

Green, H. (2012). The company town: The industrial edens and satanic mills that shaped the American economy. Basic Books.

Gregory, J. N. (2006). The southern diaspora: How the great migrations of black and white southerners transformed America. Univ of North Carolina Press. 
Grossman, J. R. (1991). Land of hope: Chicago, black southerners, and the great migration. University of Chicago Press.

Halbwachs, M., \& Coser, L. A. (1992). On collective memory. University of Chicago Press.

Hamilton, C. (2002). "Living by Fluidity": Oral Histories, Material Custodies and the Politics of Archiving. In Refiguring the archive (pp. 209-228). Springer.

Hamlin, F. N. (2012). Crossroads at Clarksdale: the Black freedom struggle in the Mississippi Delta after World War II. Univ of North Carolina Press.

Harrison, A. (2012). Black Exodus: The Great Migration of from the American South. Univ. Press of Mississippi.

Hartman, S. V. (1997). Scenes of subjection: Terror, slavery, and self-making in nineteenth-century America. Oxford University Press on Demand.

Hernández-León, R. (2013). Conceptualizing the migration industry. The Migration Industry and the Commercialization of International Migration, 25-44.

Hirschman, D., \& Reed, I. A. (2014). Formation Stories and Causality in Sociology. Sociological Theory, 32(4), 259-282.

Holton, A. (2007). Decolonizing History: Arthur Schomburg's Afrodiasporic Archive. The Journal of African American History, 92(2), 218-238.

Hughes, L. (2000). I dream a world. Paradise Press.

Hurston, Z. N. (1955). “Court Order Can”t Make the Races Mix'. Retrieved from https://www.lewrockwell.com/1970/01/zora-neale-hurston/court-order-cantmake-the-racesmix/ 
Itzigsohn, J., \& Brown, K. (2015). SOCIOLOGY AND THE THEORY OF DOUBLE CONSCIOUSNESS. Du Bois Review: Social Science Research on Race, 12(02), $231-248$.

Jacobson, M. F. (1999). Whiteness of a different color. Harvard University Press.

Lacy, K. R. (2007). Blue-chip black: Race, class, and status in the new black middle class. Univ of California Press.

Lamont, M., \& Swidler, A. (2014). Methodological pluralism and the possibilities and limits of interviewing. Qualitative Sociology, 37(2), 153-171.

Latour, B. (2007). Reassembling the social. Hampshire: Oxford University Press.

Lemann, N. (2011). The promised land: The great black migration and how it changed America. Vintage.

Levinas, E., \& Poller, N. (2003). Humanism of the Other. University of Illinois Press.

Lewis, R. L. (1987). Black coal miners in America: Race, class, and community conflict, 1780-1980. University Press of Kentucky.

Lewis, R. L. (1989). From peasant to proletarian: The Migration of southern blacks to the central Appalachian coalfields. The Journal of Southern History, 55(1), 77-102.

Locke, A. (1925). The New Negro. Simon and Schuster.

Marks, C. (1989). Farewell-We're Good and Gone: the great Black migration. Indiana Univ Pr.

Marshall, T., \& Tushnet, M. V. (2001). Thurgood Marshall: His speeches, writings, arguments, opinions, and reminiscences. Chicago Review Press.

Mbembe, A. (2002). The Power of the Archive and its Limits. In Refiguring the archive (pp. 19-27). Springer. 
Mead, G. H. (1934). Mind, self and society (Vol. 111). Chicago University of Chicago Press.

Mead, G. H. (1964). On social psychology.

Menzies, P. (2014). Counterfactual Theories of Causation. In E. N. Zalta (Ed.), The Stanford Encyclopedia of Philosophy (Spring 2014). Retrieved from http://plato.stanford.edu/archives/spr2014/entries/causation-counterfactual/

Miller, P. (2). Errand into the Wilderness. Harvard University Press.

Mills, C. W. (1997). The racial contract. Cornell University Press.

Mills, C. W. (2000). The sociological imagination. Oxford University Press.

Moten, F. (2003). In the break: The aesthetics of the black radical tradition. U of Minnesota Press.

Mungo, S. (2013). Our Own Communities, Our Own Schools: Educational CounterNarratives of African American Civil Rights Generation Students. The Journal of Negro Education, 82(2), 111-122.

Ngai, M. M. (2014). Impossible subjects: Illegal aliens and the making of modern America. Princeton University Press.

Nora, P. (1989a). Between memory and history: Les lieux de mémoire. Representations, (26), 7-24.

Nora, P. (1989b). Between memory and history: Les lieux de mémoire. Representations, (26), 7-24.

Ogletree, C. J. (2004). All deliberate speed: Reflections on the first half century of Brown v. Board of Education. WW Norton \& Company.

Omi, M., \& Winant, H. (2014). Racial formation in the United States. Routledge. 
Ortner, S. B. (2005). Subjectivity and cultural critique. Anthropological Theory, 5(1), 3152.

Patterson, O. (1982). Slavery and social death. Harvard University Press.

Pattillo, M. (2013). Black picket fences: Privilege and peril among the black middle class. University of Chicago Press.

Peck, G. (1996). Reinventing free labor: Immigrant Padrones and contract laborers in North America, 1885-1925. The Journal of American History, 83(3), 848-871.

Penrod, J., Preston, D. B., Cain, R. E., \& Starks, M. T. (2003). A discussion of chain referral as a method of sampling hard-to-reach populations. Journal of Transcultural Nursing, 14(2), 100-107.

Piore, M. J. (1979). Birds of passage: Migrant labor and industrial societies.

Polletta, F. (2009). It was like a fever: Storytelling in protest and politics. University of Chicago Press.

Polletta, F., Chen, P. C. B., Gardner, B. G., \& Motes, A. (2011). The sociology of storytelling. Annual Review of Sociology, 37, 109-130.

Portelli, A. (1990). Patterns of paternalism in Harlan County. Appalachian Journal, 17(2), $140-155$.

Portelli, A. (1992). History-telling and time: An example from Kentucky. The Oral History Review, 20(1/2), 51-66.

Portelli, A. (2009). What makes oral history different. In Oral history, oral culture, and Italian Americans (pp. 21-30). Springer. 
Portes, A., \& Böröcz, J. (1989). Contemporary immigration: Theoretical perspectives on its determinants and modes of incorporation. International Migration Review, $606-630$.

Ravenstein, E. G. (1889). The laws of migration. Journal of the Royal Statistical Society, 52(2), 241-305.

Reed, I. A. (2011). Interpretation and social knowledge: On the use of theory in the human sciences. Chicago.

Schomburg, A. A. (1925). The Negro digs up his past (Vol. 1975). Atheneum New York.

Scott, J. (1990). Domination and the Arts of Resistance: Hidden Transcripts. Yale University Press.

Seavoy, R. E., \& Tolnay, S. E. (1999). The Bottom Rung: African American Family Life on Southern Farms. JSTOR.

Sennett, R. (1972). The hidden injuries of class. CUP Archive.

Shifflett, C. A. (1995). Coal towns: Life, work, and culture in company towns of southern Appalachia, 1880-1960. Univ. of Tennessee Press.

Shircliffe, B. (2001). "We Got the Best of that World": A Case for the Study of Nostalgia in the Oral History of School Segregation. The Oral History Review, 28(2), 59-84.

Sitas, A. (2015). Unassimilable Otherness. Narrating Trauma: On the Impact of Collective Suffering, 267.

Somers, M. R. (1996). Where is sociology after the historic turn? Knowledge cultures, narrativity, and historical epistemologies. The Historic Turn in the Human Sciences, 53-89. 
Stewart, A. (2013). First Class: The Legacy of Dunbar, America's First Black Public High School. Chicago Review Press.

Taylor, D. (2003). The archive and the repertoire: Performing cultural memory in the Americas. Duke University Press.

Tilly, C. (2002). Stories, identities, and political change. Rowman \& Littlefield Publishers.

Tolnay, S. E. (2001). The Great Migration gets underway: A comparison of black southern migrants and nonmigrants in the North, 1920. Social Science Quarterly, $82(2), 235-252$.

Tolnay, S. E. (2003). The African American“ great migration” and beyond. Annual Review of Sociology, 209-232.

Tolnay, S. E., Adelman, R. M., \& Crowder, K. D. (2002). Race, regional origin, and residence in northern cities at the beginning of the Great Migration. American Sociological Review, 456-475.

Tolnay, S. E., \& Beck, E. M. (1995). A festival of violence: An analysis of southern lynchings, 1882-1930. University of Illinois Press.

Tolnay, S. E., \& Crowder, K. D. (1999). Regional origin and family stability in northern cities: The role of context. American Sociological Review, 97-112.

Tolnay, S. E., White, K. J. C., Crowder, K. D., \& Adelman, R. M. (2005). Distances Traveled during the Great Migration. Social Science History, 29(04), 523-548.

Trotter, J. W. (1985). Black Milwaukee: The making of an industrial proletariat, 1915-45. University of Illinois Press. 
Trotter, J. W. (1991). The Great Migration in historical perspective: New dimensions of race, class, and gender (Vol. 669). Indiana University Press.

Trouillot, M.-R. (1995). Silencing the past: Power and the production of history. Beacon Press.

Tuan, Y.-F. (1974). Topophilia. Englewood Cliffs, NJ: Prentice-Hall.

Turner, W. (1986). The Black Ethnographer“ At Home” In Harlan: A Commentary and Research Response to Stephenson and Greer. Human Organization, 45(3), 279282.

Venkatesh, S. A. (2008). Gang leader for a day: A rogue sociologist takes to the streets. Penguin.

Wagner-Pacifici, R. (2010). Theorizing the Restlessness of Events 1. American Journal of Sociology, 115(5), 1351-1386.

Walker, C. D. (2008). A noble fight: African American freemasonry and the struggle for democracy in America. University of Illinois Press.

Walker, V. S. (1996). Their highest potential: An African American school community in the segregated South. Univ of North Carolina Press.

Walker, V. S. (2000). Valued segregated schools for African American children in the South, 1935-1969: A review of common themes and characteristics. Review of Educational Research, 70(3), 253-285.

Walker, V. S. (2009). Hello professor: A Black principal and professional leadership in the segregated South. Univ of North Carolina Press. 
Walker, V. S., \& Byas, U. (2003). The Architects of Black Schooling in the Segregated South: The Case of One Principal Leader. Journal of Curriculum \& Supervision, 19(1).

Walker, V. S., \& Tompkins, R. H. (2004). Caring in the past: The case of a southern segregated African American school. Race-Ing Moral Formation: African American Perspectives on Care and Justice, 77-92.

Wells-Barnett, I. B. (2012). The Red Record Tabulated Statistics and Alleged Causes of Lynching in the United States. tredition.

Wells-Barnett, I. B. (2014). On lynchings. Courier Corporation.

White, K. J. C., Crowder, K., Tolnay, S. E., \& Adelman, R. M. (2005). Race, gender, and marriage: Destination selection during the Great Migration. Demography, 42(2), $215-241$.

Wilkerson, I. (2010). The warmth of other suns: The epic story of America's great migration. Vintage.

Wilkins, A. C. (2012). Becoming Black Women Intimate Stories and Intersectional Identities. Social Psychology Quarterly, 75(2), 173-196.

Williams, R. (2006). The analysis of culture. Cultural Theory and Popular Culture: A Reader, 2.

Wilson, A. (1990). Joe Turner's come and gone. Samuel French, Inc.

Wilson, W. J. (2012). The declining significance of race: Blacks and changing American institutions. University of Chicago Press.

Winant, H. (2009). The world is a ghetto: Race and democracy since World War II. basic books. 
Wolff, M. (1963). Segregation in the schools of Gary, Indiana. The Journal of Educational Sociology, 36(6), 251-261.

Woodson, C. G. (1925). Ten Years of Collecting and Publishing the Records of the Negro. The Journal of Negro History, 10(4), 598-606.

Wright, G. C. (1996). Racial Violence in Kentucky, 1865-1940: Lynchings, Mob Rule, and “ legal Lynchings. ” LSU Press.

Wynter, S. (1995). 1492: A new world view. Race, Discourse, and the Origin of the Americas: A New World View, 5-57.

Yęmisi, A., \& Hamlin, F. (Eds.). (2015). These Truly Are the Brave: An Anthology of African American Writings on War and Citizenship. University Press of Florida.

Young, A. A. (2006). The minds of marginalized black men: Making sense of mobility, opportunity, and future life chances. Princeton University Press. 


\section{APPENDIX A}

\section{Interviewee Schedule}

\begin{tabular}{|c|c|c|c|c|}
\hline Last Name & $\begin{array}{l}\text { First } \\
\text { Name }\end{array}$ & Birth Year & Birth City & $\begin{array}{l}\text { City of } \\
\text { Residence }\end{array}$ \\
\hline Akal & Derrick & 1966 & Hempstead (NY) & Lynch \\
\hline Akal & Katina & 1972 & Hempstead (NY) & Lynch \\
\hline Akal & Sherry & 1973 & Hempstead (NY) & Columbus \\
\hline Allen & Carla & 1960 & Cumberland & Cumberland \\
\hline Andrews & Arletta & 1941 & East Burdstead & Detroit \\
\hline Atkinson & Clara & 1948 & Lynch & Lynch \\
\hline Austin & Gene & 1930 & Fayette (AL) & Lynch \\
\hline Austin & Michael & 1955 & Lynch & Lynch \\
\hline Baker & Roselyn & 1942 & McRoberts & Milwaukee \\
\hline Barnes & Cynthia & 1954 & Lynch & Greensboro \\
\hline Baskin & Jaunita & 1943 & Lynch & San Jose \\
\hline Baskin & Anne & 1950 & Benham & Benham \\
\hline Baskin & Tony & 1951 & Lynch & Dayton \\
\hline Baskin & Milton & 1952 & Lynch & Dayton \\
\hline Baskin & Sanford & 1948 & Lynch & Benham \\
\hline Baskin & Dwain & 1962 & Lynch & Indianapolis \\
\hline Bickerstaff & Bernard & 1943 & Benham & Cleveland \\
\hline Bickerstaff & Joyce & 1941 & Benham & Cleveland \\
\hline Brack & Sheryl & 1947 & Lynch & Lexington \\
\hline Brown & Viola & 1938 & Lynch & Danville \\
\hline Brown & Arnita & 1953 & Lynch & Atlanta \\
\hline Brown & Linda Faye & 1953 & Lynch & Lynch \\
\hline Brown & Eddify & 1925 & Selma (AL) & Los Angeles \\
\hline Brown & Richard & 1947 & Lynch & Atlanta \\
\hline Brown & Tony & 1958 & Lynch & Lynch \\
\hline Brown & Patricia & 1953 & Cumberland & Uniondale \\
\hline Brown & Janice & 1953 & Benham & Indianapolis \\
\hline Brown & Geraldine & 1944 & Lynch & Danville \\
\hline Callaway & Harriet & 1941 & Benham & Detroit \\
\hline Callaway & Rhonda & 1951 & Benham & Little Rock \\
\hline Chapman & Richard & 1955 & Lynch & Lynch \\
\hline Clark & Lorene & 1931 & Lynch & Lynch \\
\hline Clark & Charles & 1956 & Lynch & Columbus \\
\hline Clements & Clara & 1937 & Tuscaloosa (AL) & Lynch \\
\hline Coleman & Samuel & 1957 & Lynch & Lynch \\
\hline (Anonymous) & -- & -- & -- & -- \\
\hline (Anonymous) & -- & -- & -- & -- \\
\hline Combs & Brenda & 1954 & Lynch & Lexington \\
\hline Davis & Sally & 1941 & Lynch & Covington \\
\hline
\end{tabular}




\begin{tabular}{|c|c|c|c|c|}
\hline Davis & Clarence & 1938 & Cumberland & Covington \\
\hline Davis & Wanda & 1957 & Lynch & Cleveland \\
\hline Davis & Patricia & 1944 & Lynch & Cleveland \\
\hline Davis & Lisa & 1959 & Lynch & Cleveland \\
\hline Davis & Jimmy & 1936 & Cumberland & Lima \\
\hline Ellington & Mike & 1958 & Lynch & Benham \\
\hline Ferguson & Mama & 1925 & Haynesville & Milwaukee \\
\hline Fielder & Nathaniel & 1927 & Greensboro & Louisville \\
\hline Fielder & Freda & 1931 & Harlan & Louisville \\
\hline Fikes & Charles & 1936 & Lofton (AL) & San Jose \\
\hline Freeman & Charles & 1944 & Lynch & Dayton \\
\hline French & Willie & 1942 & Lynch & Lexington \\
\hline French & Jack & 1945 & Lynch & Cleveland \\
\hline Gardner & Ike & 1930 & $\begin{array}{l}\text { Marion Junction } \\
\text { (AL) }\end{array}$ & Chicago \\
\hline Gist & James III & 1976 & Lynch & Lynch \\
\hline Gist & Edwin & 1942 & Lynch & Chicago \\
\hline Grey & Roy & 1944 & McRoberts & Detroit \\
\hline Griffen & \begin{tabular}{|l|} 
Barbara \\
\end{tabular} & 1944 & Lynch & Waterbury \\
\hline Griffen & Tommy Jr. & 1949 & Lynch & Waterbury \\
\hline Griffey & Lacey & 1928 & Benham & Benham \\
\hline Hall & Joyce & 1951 & Lynch & Waterbury \\
\hline Hampton & Deborah & 1954 & Benham & Lynch \\
\hline Hampton & Ronnie & 1951 & Lynch & Lynch \\
\hline Harris & Albert & 1950 & Benham & Sunrise \\
\hline Haskins & Rosie & 1940 & McRoberts & Milwaukee \\
\hline Haury & Barbara & 1942 & Lynch & Chicago \\
\hline Hauser & Arthur & 1954 & Lynch & Indianapolis \\
\hline Hauser & Barney & 1956 & Lynch & Indianapolis \\
\hline Howard & Sam & 1942 & Lynch & Louisville \\
\hline Hudson & Donald & 1931 & Jenkins & Detroit \\
\hline Huston & James & 1945 & Lynch & Detroit \\
\hline Jackson & Gerald Wayne & 1950 & Lynch & Lynch \\
\hline Jackson & Lee Arthur & 1950 & Lynch & Lexington \\
\hline Jackson & \begin{tabular}{|l|} 
William \\
\end{tabular} & 1944 & Lynch & Los Angeles \\
\hline Jones & \begin{tabular}{|l|} 
Lena \\
\end{tabular} & 1940 & Lynch & Louisville \\
\hline Kendrick & Sylvester & 1949 & Lynch & Beavercreek \\
\hline Ledford & Helen & 1932 & Lynch & Cumberland \\
\hline Lee & Lacey & 1943 & Benham & Atlanta \\
\hline Lee & Leslie & 1948 & Lynch & Harlan \\
\hline Mason & Delores & 1943 & Lynch & Lexington \\
\hline Mason & \begin{tabular}{|l|} 
Vergie \\
\end{tabular} & 1923 & Mount Sterling & Columbus \\
\hline Mason & Mike & 1952 & Lynch & Columbus \\
\hline Mason & Terry & 1958 & Lynch & Columbus \\
\hline Mason & Curtis & 1948 & Lynch & Chicago \\
\hline Massey & George & 1952 & Lynch & Lynch \\
\hline Massey & \begin{tabular}{|l|} 
Bennie \\
\end{tabular} & 1949 & Lynch & Lynch \\
\hline Massey & Teresa & 1968 & Lynch & Lynch \\
\hline McBath & Lelia & 1926 & Lynch & Los Angeles \\
\hline
\end{tabular}




\begin{tabular}{|c|c|c|c|c|}
\hline McCaskill & Yvonne & 1946 & Fleming & Milwaukee \\
\hline McDonald & Eddie & 1928 & Benham & Detroit \\
\hline Merton & Rutland & 1948 & Lynch & Lynch \\
\hline Mimes & \begin{tabular}{|l|} 
Theresa \\
\end{tabular} & 1958 & Lynch & Lynch \\
\hline Mitchel & Lois & 1953 & Lynch & Lynch \\
\hline Mitchel & Cynda & 1950 & Lynch & Lynch \\
\hline Moore & Ervine & 1935 & McRoberts & Milwaukee \\
\hline Morris & \begin{tabular}{|l|} 
Beverly \\
\end{tabular} & 1949 & Benham & Los Angeles \\
\hline Morrow & William & 1922 & Plantersville (AL) & Lynch \\
\hline Morrow & \begin{tabular}{|l|} 
Dwayne \\
\end{tabular} & 1952 & Lynch & Lynch \\
\hline Moss & Odell & 1932 & Benham & Lexington \\
\hline Moss & Edgar James & 1940 & Benham & Newington \\
\hline Moss & Armenia & 1935 & Benham & Cleveland \\
\hline Moss & Jean & 1938 & Benham & Bedford Hts \\
\hline Motley & \begin{tabular}{|l|} 
Roland \\
\end{tabular} & 1934 & Benham & Chagrin Falls \\
\hline Motley & Timothy & 1961 & Benham & Benham \\
\hline Napier & Belinda & 1951 & Syman (VA) & Cumberland \\
\hline Nolan & Brenda & 1958 & Cumberland & Dayton \\
\hline Parks & Katie Sue & 1948 & Lynch & Lorraine \\
\hline Peavy & Ronnie & 1947 & Cumberland & Dayton \\
\hline Peeples & Porter G. & 1945 & Lynch & Lexington \\
\hline Peeples & Billy & 1948 & Lynch & Springfield \\
\hline Peeples & Vera & 1948 & Cumberland & Springfield \\
\hline Perry & \begin{tabular}{|l|} 
Humes \\
\end{tabular} & 1942 & Lynch & Waterbury \\
\hline Perry & \begin{tabular}{|l|} 
James \\
\end{tabular} & 1940 & Lynch & Waterbury \\
\hline Pettygrue & Ernest & 1938 & Lynch & Indianapolis \\
\hline Pettygrue & Rosie & 1937 & Greensburg & Indianapolis \\
\hline Pollenitz & Robert & 1927 & Benham & Chicago \\
\hline Powell & Betty & 1937 & Clinton (AL) & Dayton \\
\hline Price & Charles & 1933 & Louisville & Indianapolis \\
\hline Prinkleton & Victor & 1944 & Lynch & Lexington \\
\hline Ratchford & Jeff & 1956 & Lynch & Atlanta \\
\hline Ratchford & Jerome & 1942 & Lynch & Atlanta \\
\hline Ratchford & Cynthia & 1949 & Lynch & San Jose \\
\hline Ratchford & Jacquelyn & 1945 & Lynch & San Jose \\
\hline Richardson & Ruth & 1928 & Evarts & Dayton \\
\hline Robinson & Vera & 1937 & Lynch & Indianapolis \\
\hline Rodgers & Chuck & 1953 & Lynch & Lexington \\
\hline Ryland & Mullins & 1942 & Lynch & Columbus \\
\hline Shaffer & \begin{tabular}{|l|} 
William \\
\end{tabular} & 1926 & Lynch & Chicago \\
\hline Simmons & Arthur & 1937 & Lynch & Chicago \\
\hline Smith & Clara & 1942 & Cumberland & Detroit \\
\hline Smith & Herbert & 1945 & Cumberland & Detroit \\
\hline Smith & George & 1932 & Butler (AL) & Cleveland \\
\hline Stevens & James & 1935 & Killbear (AL) & Cleveland \\
\hline Stevens & Roy & 1954 & Lynch & Lynch \\
\hline Steward & John & 1942 & Cincinnati $(\mathrm{OH})$ & Los Angeles \\
\hline Taylor & George & 1950 & Cumberland & Dayton \\
\hline Thomas & Ron & 1949 & Lynch & Indianapolis \\
\hline
\end{tabular}




\begin{tabular}{|l|l|l|l|l|} 
Thompson & Norman & 1949 & Lynch & Cleveland \\
\hline Thornton & Brenda & 1950 & Lynch & White Plains \\
\hline Thrasher & Joyce & 1946 & Benham & Indianapolis \\
\hline Turner & Jeff & 1959 & Lynch & Indianapolis \\
\hline Turner & Millie & 1966 & Hazard & Indianapolis \\
\hline Uvella & Mullins & 1937 & Lynch & Columbus \\
\hline Vivian & Mullins & 1936 & Lynch & Columbus \\
\hline Ward & Virginia & 1949 & Cumberland & Dayton \\
\hline Ward & William & 1942 & Lynch & Chicago \\
\hline Whitt & Raveryn & 1955 & Benham & Cumberland \\
\hline Williams & Debra & 1958 & McRoberts & Lexington \\
\hline Williams & Vyreda & 1947 & Lynch & Cleveland \\
\hline Williams & Jimmy & 1943 & Jenkins & Cleveland \\
\hline Williams & Betty & 1944 & Benham & Indianapolis \\
\hline Willis & Jessie & 1920 & Irvington (GA) & Detroit \\
\hline Wilson & Ruthie Mae & 1949 & Lynch & Benham \\
\hline
\end{tabular}




\section{APPENDIX B}

\section{Consent and Deed of Gift Forms}

\section{IRB Consent Form}

\section{Ties that Bind: The Impact of Migrant Networks on Migration, Resettlement and}

\section{Integration Over the Life Course}

Karida L. Brown, Graduate Student

Department of Sociology | Brown University

I, have been invited to provide an oral history interview for this dissertation research. I understand that Karida L. Brown is interviewing African Americans from Harlan, Letcher, and Fletcher Counties, Kentucky to trace the outmigration to cities throughout the United States. I also understand that she may use material from my interview in her dissertation and possibly in subsequent publications. Unless I indicated otherwise, there will be no restrictions on the use of my interview by either Karida L. Brown or the university archive.

\section{Research Methodology and Interviewee Rights}

This audio/video-recorded interview will be conducted in the form of a guided conversation and will last from 45 minutes to an hour. I understand that I will be free to decline to answer any question that I consider to be uncomfortable or inappropriate. Moreover, I will have the right to stop interview at any time without any negative consequences. There are no foreseeable risks to my participation. While there may be no direct benefit to me, this interview may contribute towards increased public knowledge about my personal experience with the Black migration out of southeastern Kentucky for researchers, my descendents, and the general public. There is no cost to my participation in this study, and I will not receive any compensation in exchange for a recording of my interview. I further recognize that there is no assumption of confidentiality unless I specifically request it.

For research purposes keep the interview entirely confidential

For research purposes use a fictitious name

For research purposes use actual names.

\section{Questions \& Concerns}

If you have any questions or concerns about this study or the oral history process, you can contact Karida L. Brown at (401) 500.1662 or Karida_Johnson@brown.edu, or her faculty advisor Jose Itzigsohn at (401) 863.2528 or Jose_Itzigsohn@brown.edu. If you have questions about your rights as a research participant, you may also contact the Brown University Office of Research Integrity at (401) 863. 3050. 
$\overline{-1}$

Interviewee

Karida L. Brown

Date

Date

Mailing Address 


\title{
Deed of Gift Form
}

\author{
Deed of Gift \\ I \\ , do herein permanently donate and convey my oral \\ history interview to Karida L. Brown. In making this gift, I understand that I am assigning \\ all right, title, and interest in copyright to Karida L. Brown.
}

I further understand that she wishes to donate my interview to a university library archive to make the interview available to the public; including researchers, lay people, and my family and descendents. This interview can be used in any number of ways, such as for academic research, book publications, or documentaries. While there is no direct benefit to me, this donation may add significant value to our current knowledge about African American history and culture. This donation may include the transfer of all interest in copyright that I herein assigned. Karida L. Brown agrees in turn to inform me of the library or archive that will ultimately be the repository of my interview/s and materials.

I choose to:

Keep the interview entirely confidential.

Do NOT gift my interview to a university library.

Make the interview publicly available using a fictitious name Gift my interview to a university library using a fictitious name.

Consent to make the interview publicly available using actual names.

Gift my interview to a university library using my actual name.

\section{Questions \& Concerns}

If you have any questions or concerns about this study or the oral history donation process, you can contact Karida L. Brown at (401) 500.1662 or Karida_johnson@brown.edu.

Interviewee

Date
Karida L. Brown

Date 
